\title{
TOXIDEZ DO NİQUEL EM ARROZ E FEIJÃO
}

\author{
DANIEL FERNANDO PICCINI ANTÓN
}

\begin{abstract}
Tese apresentada à Escola Superior de Agricultura "Luiz de Queiroz", da Universidade de São Paulo, para obtenção do título de Doutor em Agronomia, Ārea de Concentração: Solos e Nutrição de Plantas
\end{abstract}

\author{
PIRACICABA \\ ESTADO DE SÃO PAULO-BRASIL \\ NOVEMBRO - 1990
}




\title{
TOXIDEZ DO NİQUEL EM ARROZ E FEIJÃO
}

\author{
DANIEL FERNANDO PICCINI ANTÓN \\ Engenheiro Agrônomo
}

Orientador: Prof.Dr. Euripedes Malavolta

Tese apresentada à Escola Superior de Agricultura "Luiz de Queiroz", da Universidade de São Paulo, para obtenção do título de Doutor em Agronomia, Ārea de Concentração: Solos e Nutrição de Plantas

\author{
PIRACICABA \\ ESTADO DE SÃO PAULO-BRASIL \\ NOVEMBRO - 1990
}


TOXIDEZ DO NIQUEL EM ARROZ E FEIJÃO

Daniel Fernando Piccini Antōn

Aprovado em 08/02/1991

COMISSÃO JULGADORA :

Prof.Dr. Eurípedes Malavolta ESALQ/USP

Prof.Dr. Francisco de Assis Ferraz de Mello ESALQ/USP

Prof.Dr. Takashi Muraoka CENA/USP

Dr. José Maria Ayres Valadares IAC

Dr. Ciro Rosolem UNESP / Botucatu

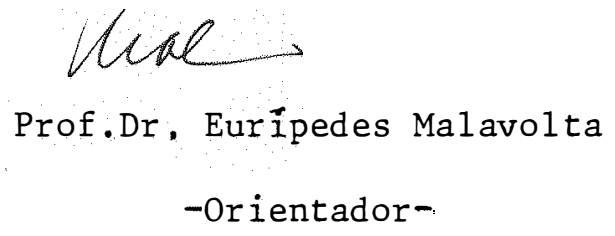


Aos meus queridos pais,

Daniel Ildefonso e Maryblanca,

e aos meus irmãos, com

gratidão

OFEREÇO

A minha esposa Marina Esther, A minha filha Maria Fernanda 
Ao Prof.Dr. Eurípedes Malavolta pela orientação, colaboração, compreensão, estỉmulo e amizade;

$\bar{A}$ ESALQ, CENA, CIAGRI, FINEP, ANDA e UNAS, pelas oportunidades de aperfeiçoamento oferecidas;

Aos Professores Geraldo Victorino de França, Zilmar Ziller Marcos e Josẻ Luiz Ioriatti Demattê, pela atenção e sinceridade;

$\bar{A}$ Dra. Neusa de Lima Nogueira pelas sugestões e colaboração nos estudos de Microscopia Eletrônica;

Aọs Técnicos de Laboratōrio Cleusa Pereira Cabral, Maria Lỉgia Malavolta, Mönica Lanzoni e José Elias Gomes, pela colaboração;

Aos colegas de curso Valdinei Tadeu Paulino e Vera Lūcia Martins de Caryalho pelas sugestões na realização deste trabalho;

Ao Conselho Nacional de Desenvolvimento Científico e Tecnológico pela bolsa de estudos concedida;

Aos funcionārios da Divisão de Biblioteca e Documentação da Prefeitura do Campus de Piracicaba Kátia M.P.de Andrade e Eliana Maria Garcia Sabino, pelo auxílio durante a elaboração deste trabalho;

Às funcionárias da Seção de Pós-Graduação, pela atenção dispensada durante estes longos anos de convivência;

$\bar{A}$ Sra. Elisa S. Peron, pelo excelente trabalho datilográfico. 
SUMĀRIO

Pāgina

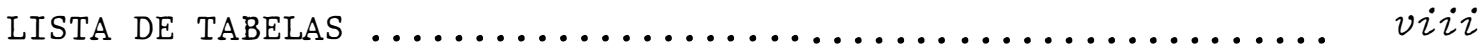

LISTA DE FIGURAS $\ldots \ldots \ldots \ldots \ldots \ldots \ldots \ldots \ldots \ldots \ldots \ldots \ldots \ldots \ldots \ldots \ldots \ldots \ldots \ldots$

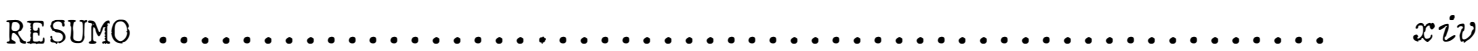

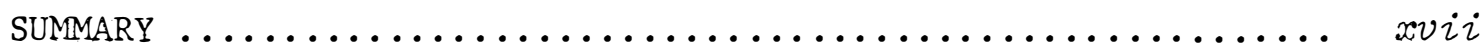

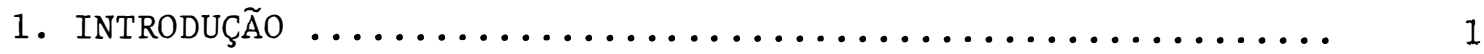

2. REVISÃO DE LITERATURA $\ldots \ldots \ldots \ldots \ldots \ldots \ldots \ldots \ldots \ldots \ldots \ldots \ldots \ldots$

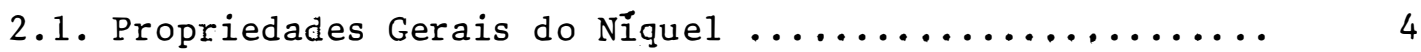

2.2. Nique1 nos Solos $\ldots \ldots \ldots \ldots \ldots \ldots \ldots \ldots \ldots \ldots \ldots \ldots \ldots \ldots \ldots \ldots \ldots$

2.2.1. Niquel total $\ldots \ldots \ldots \ldots \ldots \ldots \ldots \ldots \ldots \ldots \ldots \ldots \ldots$

2.2.2. Níquel extraive1 $\ldots \ldots \ldots \ldots \ldots \ldots \ldots \ldots \ldots \ldots$

2.2.3. Formas de $\mathrm{Ni}$ nos solos $\ldots \ldots \ldots \ldots \ldots \ldots \ldots \ldots \ldots \ldots$

2.2.4. Adsorção e complexação do $\mathrm{Ni}$ no solo .......... 9

2.2.5. Fatores que afetam sua movimentação e disponibilidade .................... 10

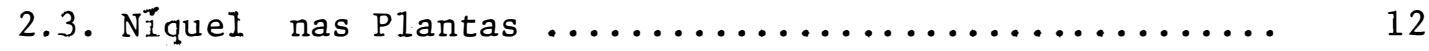

2.3.1. Níquel na nutrição das plantas ............ 12

2.3.2. Efeitos benéficos do Ni no desenvolvimento das plantas ......................... 14

2.3.3. Interações do $\mathrm{Ni}$ com outros elementos ........ 15

2.3.4. Toxidez de $\mathrm{Ni}$ e seu controle .............. 16

2.3.5. Plantas acumuladoras e hiperacumuladoras ...... 18

2.3.6. Sintomatologia da deficiência e toxidez

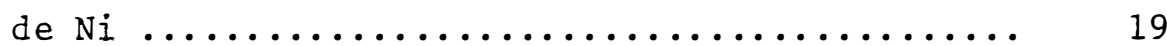


Página

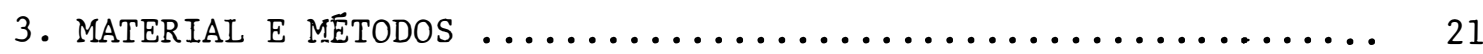

3.1. Cultivares ou variedades utilizadas $\ldots \ldots \ldots \ldots \ldots \ldots \ldots 21$

3.2. Ensaios em solução nutritiva .................. 21

3.2.1. Procedimento geral $\ldots \ldots \ldots \ldots \ldots \ldots \ldots \ldots \ldots \ldots .21$

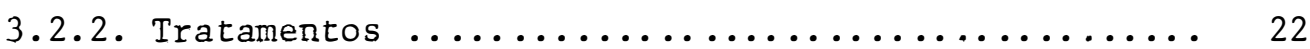

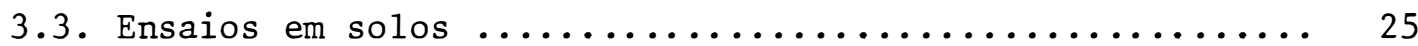

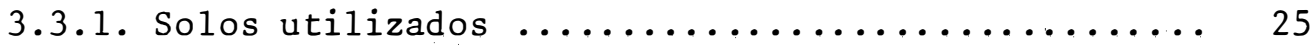

3.3.2. Procedimento geral $\ldots \ldots \ldots \ldots \ldots \ldots \ldots \ldots \ldots . \ldots \ldots$

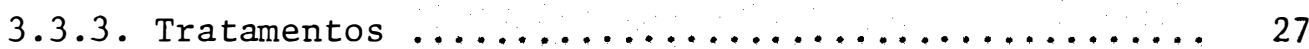

3.4. Análise do teor de clorofila total ............... 29

3.5. Estudos de Microscopia Eletrônica ................. 29

3.6. Colheita e preparo do material para análise ......... 30

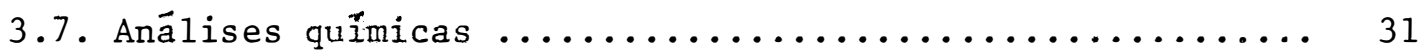

3.8. Delineamento experimental e análise estatística ....... 32

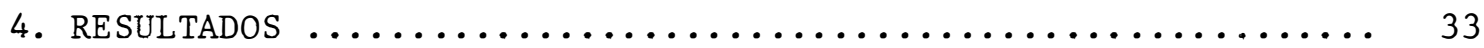

4.1. Ensaios em solução nutritiva $\ldots \ldots \ldots \ldots \ldots \ldots \ldots \ldots \ldots \ldots$

4.1.1. Ensaio 1. Estabelecimento dos niveis de Ni a serem utilizados $\ldots \ldots \ldots \ldots \ldots \ldots \ldots \ldots \ldots$

4.1.2. Ensaio 2. Avaliação dos efeitos da toxidez de $N i$ em feijão .................... 36

4.1.3. Ensaio 3. Avaliação dos efeitos da toxidez de Ni em dois cultivares de feijão ........ 39

4.1.4. Ensaio 4. Avaliação dos efeitos da toxidez de Ni em duas variedades de arroz ......... 46 
4.1.6. Estudos preliminares dos efeitos da toxidez de Ni nas folhas de arroz e feijão, a nỉvel ultraestrutural ................ 54

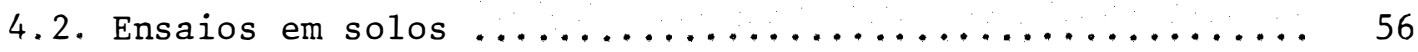

4.2.1. Avaliação dos efeitos da toxidez de $\mathrm{Ni}$ em três solos ácidos .................... 56

4.2.2. Avaliação dos efeitos da calagem no controle da toxidez de $\mathrm{Ni}$ em dois solos ácidos ......

4.2.3. Ni-solüvel em DTPA-TEA em solos ácidos com e sem calagem ...................... 7

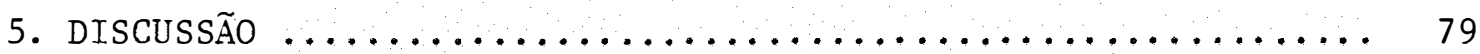

5.1. Ensaios em solução nutritiva ................. 79

5.1.1. Produção de matéria seca ............... 79

5.1.2. Teor de nutrientes e níquel em feijão e

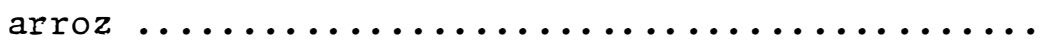

5.1.3. Estudos preliminares dos efeitos da toxidez de Ni nas folhas de arroz e feijão, a

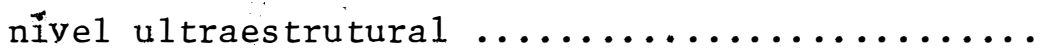

5.1.4. Sintomatologia da toxidez de $\mathrm{Ni} \ldots \ldots \ldots \ldots \ldots$

5.2. Ensaios em solos $\ldots \ldots \ldots \ldots \ldots \ldots \ldots \ldots \ldots \ldots \ldots \ldots \ldots$

5.2.1. Efeitos da toxidez de $\mathrm{Ni}$ em três solos

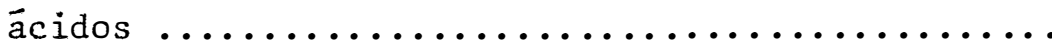

5.2.2. Efeitos da calagem no controle da toxidez

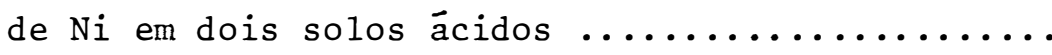


5.2.3. Ni-solúvel em DTPA-TEA em solos ácidos com e sem calagem ....................... 91

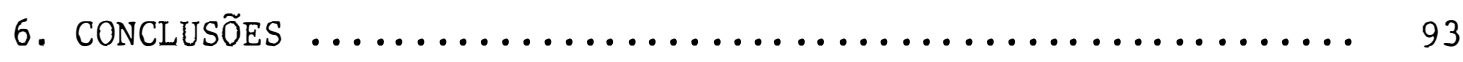

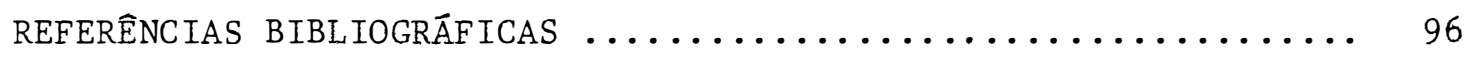

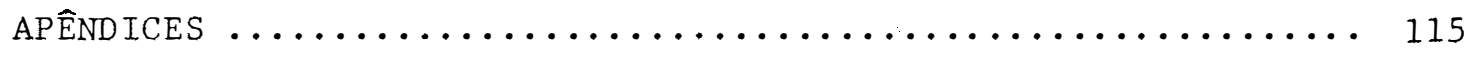


2 Produção de matéria seca nas culturas de arroz e feijão, em função dos níveis de níquel na solu-

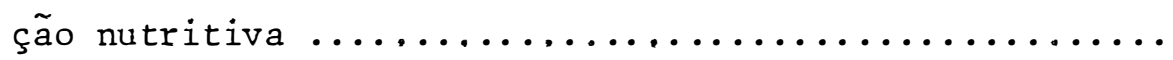

3 Produção de matéria seca e teor de clorofila total em feijão cultivar Carioca, em função dos níveis de níquel na solução nutritiva ............ 37

4 Produção de matéria seca de dois cultivares de feijão coletados por ocasião da floração e da formação de grãos, e teor de clorofila total nas folhas, em função dos níveis de níquel na solu-

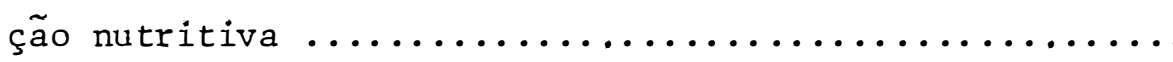

5 Equações de regressão entre teores de nutrientes e níquel (\% e ppm) em dois cultivares de feijoeiro (Y), e ppm de $\mathrm{Ni}(\mathrm{X})$ na solução nutritiva

6 Produção de matéria seca de duas variedades de arroz, coletadas por ocasião do máximo perfilhamento e da formação de grãos, e teor de clorofila total, em função dos níveis de níquel na solução nutritiva

7 Equações de regressão entre teores de nutrientes e níquel (\% e ppm) em duas variedades de arroz (Y), e ppm de $\mathrm{Ni}(\mathrm{X})$ na solução nutritiva... 
8 Produção de matéria seca em feijão cultivar Cario ca, em função dos nỉveis de nỉquel, em três solos ..... 57

9 Equações de regressão entre teores de nutrientes e níquel (\% e ppm) de feijoeiro (Y), e ppm de níquel (X) em três solos ácidos .................. 59

10 Produção de matéria seca em arroz variedade IAC165, em função dos níveis de níquel em três solos ..... 63

11 Equações de regressão entre teores de nutrientes e níquel (\% e ppm) em arroz (Y), e ppm de níquel

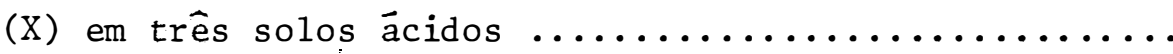

12 Produção de matéria seca em feijão cultivar Carioca, em função dos níveis de níquel e da cala-

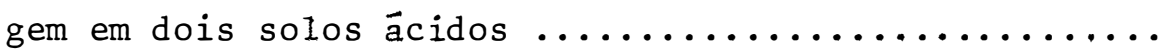

13 Equações de regressão entre teores de nutrientes e níquel (\% e ppm) em feijoeiro (Y), e ppm de nĩquel $(\mathrm{X})$ em dois solos äcidos com e sem calagem ......

14 Produção de matéria seca em arroz variedade IAC165 em função dos níveis de níquel e da calagem

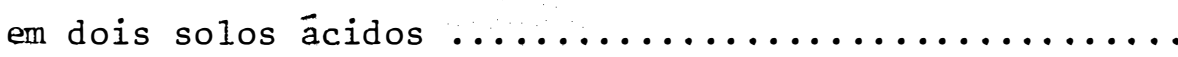

15 Equações de regressão entre teores de nutrientes e níquel (\% e ppm) em arroz (Y), e ppm de níquel

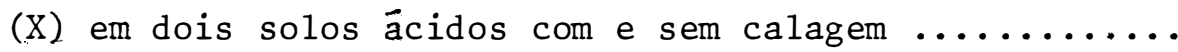


16 Equações de regressão entre a produção de matéria seca total (g/vaso) nas culturas de arroz e feijão (Y), e $\mu \mathrm{g} / \mathrm{ml}$ de Ni-solúvel em DTPA-TEA (X) em três solos äcidos

17 Equações de regressão entre a produção de matéria seca total (g/vaso) nas culturas de arroz e feijão (Y), e $\mu \mathrm{g} / \mathrm{m} 1$ de Ni-solúvel em DTPA-TEA (X) em

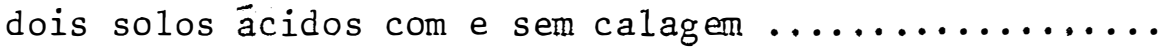


1 Relação entre a produção de matéria seca total (g/vaso) nas culturas de arroz e feijão, e níveis de níquel (ppm) na solução nutritiva $\ldots \ldots \ldots \ldots \ldots 35$

2 Relação entre a produção de matéria seca total (g/vaso) e o teor de clorofila total nas folhas ( $\mathrm{kg} / g$ de matéria fresca) de feijão, e níveis de níquel (ppm) na solução nutritiva $\ldots \ldots \ldots \ldots \ldots \ldots \ldots . \ldots \ldots$

3 Relação entre as quantidades totais de $\mathrm{P}$ e $\mathrm{Mg}$ (mg/vaso), Cu e Mn ( $\mu$ g/vaso) no feijoeiro, e níveis de níquel (ppm) na solução nutritiva $\ldots \ldots \ldots \ldots \ldots$

4 Relação entre a produção de matéria seca total da primeira coleta ( $\mathrm{g} / \mathrm{vaso}$ ), teor de clorofila to tal nas folhas ( $\mu \mathrm{g} / \mathrm{g}$ de matëria fresca) e produção de matéria seca total da segunda coleta nos dois cultivares de feijão (Carioca e IAPAR-14), e niveis de niquel (ppm) na solução nutritiva $\ldots . \ldots \ldots$

5 Relação entre os teores de nutrientes e níquel (\% e ppm) nas folhas de feijão para as duas coletas (floração e formação de grãos), e níveis de niquel (ppm) na solução nutritiva ............. 45

6 Relação entre a produção de matéria seca total da primeira coleta (g/vaso), teor de clorofila total ( $\mu \mathrm{g} / \mathrm{g}$ de matéria fresca) e produção de matéria seca total da segunda coleta nas duas variedades de arroz (IAC-165 e IAC-4440), e níveis de níquel (ppm) na solução nutritiva ............ 48 
7 Relação entre os teores de nutrientes e níquel (\% e ppm) nas folhas de arroz para as duas coletas (perfilhamento e formação de grãos), e nïveis de níquel (ppm) na solução nutritiva $\ldots \ldots \ldots \ldots \ldots$

8 Eletrofotomicrografias de tecidos foliares de plantas de feijoeiro cv. Carioca (A) e de arroz v. IAC-165 (B) cultivadas em soluções nutritivas contendo $\mathrm{Ni}(\mathrm{ppm})$ nos níveis de $\mathrm{A}_{1}=0 ; \mathrm{A}_{2}=4$;

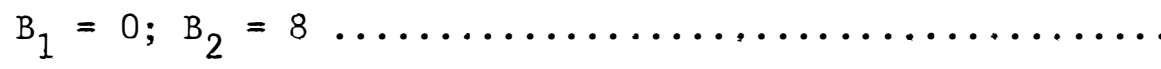

9 Relação entre a produção de matéria seca total (g/vaso) em feijoeiro, e níveis de níquel (ppm) em très solos äcidos $\ldots \ldots \ldots \ldots \ldots \ldots \ldots \ldots \ldots \ldots \ldots$

10 Relação entre teores de nutrientes e níquel (\% e ppm) nas folhas de feijoeiro, e níveis de níquel $(\mathrm{ppm})$ no solo ...........................6 60

11 Relação entre a produção de matéria seca total (g/vaso) em arroz, e níveis de níquel (ppm) em

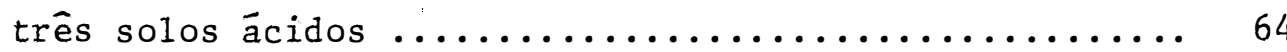

12 Relação entre teores de nutrientes ( $\%$ e ppm) nas folhas de arroz, e níveis de níquel (ppm) no solo ..... 66

13 Relação entre a produção de matéria seca total (g/vaso) em feijoeiro, e níveis de níquel em dois

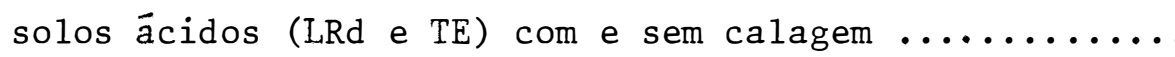


Figura n?

Pāgina

14 Relação entre teores de $\mathrm{Mn}$ e $\mathrm{Ni}$ (ppm) nas folhas

de feijoeiro, e níveis de níquel no solo com e

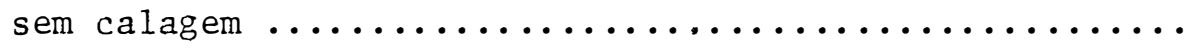

15 Relação entre teores de Mn (ppm) nas folhas de arroz, e níveis de níquel no solo com e sem ca-

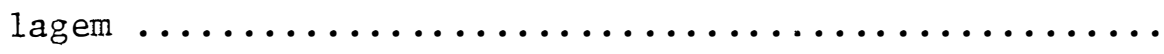


TOXIDEZ DO NIQUEL EM ARROZ E FEIJĀO

Autor: Daniel Fernando Piccini Antón Orientador: Euripedes Malavolta

\section{RESUMO}

Com o objetivo de estudar os efeitos da toxidez de $\mathrm{Ni}$ nas culturas de arroz (Oryza sativa L.) e de feijão (Phaseolus vulgapis L.), foram realizados experimentos em solução nutritiva e solos ácí dos, com adição de doses crescentes de Ni. Observou-se também os efeitos da calagem de solos äcidos no controle da toxidez de $\mathrm{Ni}$.

Em solução nutritiva, as doses de $\mathrm{Ni}$ foram $0,1,2,4$, 8 e 16 ppm, para ambas espécies de plantas. A queda na produção da ma téria seca total em função de doses crescentes de Ni, demonstra uma maior tolerância a altas doses de $\mathrm{Ni}$ do arroz em relação ao feijão. To mando como base estes resultados estabeleceram-se as doses de $\mathrm{Ni}$ a serem utilizadas nas culturas de feijão ( $0,1,2$ e 4 ppm) e do arroz (0, 4, 8 e $12 \mathrm{ppm})$.

No feijão, comparando a produção de matéria seca total de dois cultivares observou-se que o cultivar IAPAR-14 mostrou-se ser mais tolerante do que o cultivar Carioca a altas doses de $\mathrm{Ni}$ em solução nutritiva. No arroz, também se verificaram diferenças varietais, 
em relação a sua tolerância a altas doses de Ni. A variedade IAC - 165 foi um pouco mais tolerante do que a variedade IAC-4440. Análise dos teores de nutrientes mostra que o $\mathrm{Ni}$ afeta a absorção de nutrientes, sendo observadas as seguintes interações antagônicas: $\mathrm{Ni} \times \mathrm{Mg}$ e $\mathrm{Ni} \times \mathrm{Fe}$ no feijão, .Ni x Ca, Ni x Mg e Ni x Mn no arroz. Também verificou-se que - $\mathrm{Ni}$ acumula-se principalmente nas raízes das plantas.

Estudos a nivel ultra-estrutural em folhas de arroz e feijão mostraram que altas doses de $\mathrm{Ni}$ afetam principalmente os cloroplastos. Por outro lado, os teores de clorofila total nas folhas de ar roz e feijão reduziram-se conforme aumentaram-se as doses de Ni na solução nutritiva.

A sintomatologia característica da toxidez do $\mathrm{Ni}$ em plan tas de arroz e de feijão consistiu na presença de clorose internervural de folhas novas que progride rapidamente para as folhas mais velhas. No arroz, a folha inteira pode ficar esbranquiçada. Em estádios mais adiantados, apareceram manchas necróticas na parte aérea da planta, e ocor reu uma diminuição no tamanho. No sistema radicular reduziu-se o cres cimento das raízes laterais. As raízes foram de menor tamanho, quebradiças e de aparência "coralóide".

Experimentos realizados em três solos (V, LRd e TE), com adições de doses crescentes de $\mathrm{Ni}(0,30,60$ e 120 ppm), mostraram que altas doses de $\mathrm{Ni}$ reduziram a produção de matéria seca total no fei jão e no arroz. No Vertisolo (V) estes efeitos não foram significativos, devido a sua menor acidez e maior fertilidade natural, em relação 
aos outros solos (LRd e TE). Tambēm, as altas doses de Ni induziram in terações antagōnicas do $\mathrm{Ni} \operatorname{com} \circ \mathrm{Ca}$, Mn e $\mathrm{Zn}$ no feijão, e com o $\mathrm{Ca}, \mathrm{Mg}$, Mn e Zn no arroz. Os teores de $\mathrm{Ni}$ na matéria seca foram maiores nas plantas que cresceram nos solos Liatosolo Roxo distrófico (LRd) e Terra Roxa Estruturada (TE), em relação ao Vertisolo (V). Existem correlações positivas significativas entre os teores foliares de $\mathrm{Ni}$ no arroz e no feijão, e doses crescentes de Ni nos três solos (V, LRd e TE).

A calagem dos solos ácidos (LRd e TE) controlou os efei tos tóxicos de altas doses de $\mathrm{Ni}$ sobre a produção de matéria seca no feijão, enquanto que no arroz estes efeitos não foram significativos. Nos solos com adições de doses crescentes de $\mathrm{Ni}$, a calagem reduziu a disponibilidade do Fe, Mn e Ni no feijão, e do Mn e Ni no arroz. As anā lises do Ni solúvel em DTPA-TEA mostraram que a calagem de solos ácidos (LRd e TE) diminuiu o teor de $\mathrm{Ni}$ disponível nos dois solos. Tambēm, nos três solos estudados, observou-se uma tendência a aumentar os teores de Ni solúvel em DTPA-TEA, em relação a doses crescentes de Ni adiciona das ao solo. Constatou-se correlação negativa entre o teor de Ni solūvel em DTPA-TEA nos três solos e a produção de matéria seca total no ar roz e no feijão. 
Author: Daniel Fernando Piccini Antōn Adviser: Euripedes Malavolta

\section{SUMMARY}

In order to study the toxic effects of $\mathrm{Ni}$ on rice (Oriza sativa L.) and common beans (Phaseolus iulgaris L.), experiments were carried out in nutrient solution and in soils (in the presence and absence of lime).

In nutrient solution a preliminary trial was set up using, for both species, $0,1,2,4,8$ and $16 \mathrm{ppm} \mathrm{Ni}$. The results, evaluated in terms of dry matter yield, showed that rice plants were relatively more tolerant than beans. For this reason a new experiment was conducted with the following rates of $\mathrm{Ni}$ supplied to the nutrient solutions: beans $-0,1,2$ and 4 ppm; rice $-0,4,8$ and $12 \mathrm{ppm}$.

A comparison between two bean cultivars revealed that IAPAR-14 was more tolerant than Carioca. In the case of rice varietal differences were also found: IAC-4440 showed a lower tolerance than IAC -165 .

Tissue analyses disclosed a $\mathrm{Ni}$ effect on the uptake of other nutrients of the antagonistic type: $\mathrm{Ni} \times \mathrm{Mg}$ and $\mathrm{Ni} \times \mathrm{Fe}$ in beans, 
and $\mathrm{Ni} \times \mathrm{Ca}, \mathrm{Ni} \times \mathrm{Mg}$ and $\mathrm{Ni} \times \mathrm{Mn}$ in the rice plant. It was also verified that $\mathrm{Ni}$ is accumulated preferentially in the root system.

Electron micrographs showed that high $\mathrm{Ni}$ dosages adversely affected the cell components, especially the chloroplasts. This is in agreement with the fact that chlorophyll concentration in the leaves of both species decreased as the $\mathrm{Ni}$ supply increased.

A characteristic symptom of $\mathrm{Ni}$ toxicity is an interveinal chlorosis of the younger leaves which rapidly appears in the older ones as well. Later on necrotic spots develop in the tops, and a reduction in size is observed. The root system was also affected: less lateral branching; main roots were shorter, easy to break, resembling coral formation.

Three acid soils (Vertisol, V, Roxo Latosol distrophic, LRd, and Dusky Red Latosol, TE) were supplied with 0, 30, 60 and 120 ppm Ni. Higher rates decreased dry matter production, although in the case of $\mathrm{V}$ the effects were not significant possibly due to its higher natural fertility. The chemical analyses of the plant material showed antagonistic effects between $\mathrm{Ni}$ and other elements ( $\mathrm{Ca}, \mathrm{Mn}$ and $\mathrm{Zn}$ in beans, $\mathrm{Ca}, \mathrm{Mg}$, $\mathrm{Mn}$ and $\mathrm{Zn}$ in rice). Ni concentration in the tissue was higher in plants grown either in LR or TE. Positive correlations between $\mathrm{Ni}$ applied and tissue $\mathrm{Ni}$ were found in both species in the three soil types.

Liming LRd and TE was able to control the adverse effects of $\mathrm{Ni}$ on dry matter production by beans, where as in the case of rice 
the effect was not significant. The availability of $\mathrm{Fe}$, Mn and $\mathrm{Ni}$ for the bean plant, and of $\mathrm{Mn}$ and $\mathrm{Ni}$ for rice, was decreased by liming, as shown by DTPA - TEA extraction, in the case of the two acid soils (LRd and TE). Extractable Ni increased with the rates of application. A negative correlation was also found between DTPA - TEA soluble $\mathrm{Ni}$ and dry matter yield. 
1. INTRODUÇÃO

Geralmente, os estudos nutricionais em plantas não consideram o elemento nỉquel, por acreditar que sua ação é pouco significativa no desenvolvimento das plantas, sendo identificado como um elemento traço. Porém, inúmeras pesquisas rëalizadas nesta segunda metade de século demonstram a importância nutricional do níquel em animais (NIELSEN \& OLLERICH, 1974), bactērias (THAUER et alii, 1980), algas azu1-verdes (VAN BAALEN \& O'DONNELL, 1978) e plantas (MARTINI, 1930; DIXON et alii, 1975; ESKEW et alii, 1984; BROWN et alii, 1987). O principal fato que estabelece sua essencialidade nas plantas è sua participação na estrutura da enzima urease (DIXON et alii, 1975; POLACCO \& HAVIR, 1979; WATANABE \& SHIMADA, 1990).

Embora a essencialidade do Ni esteja hoje demonstrada, comumente é considerado como um elemento tóxico antropogênico. Sendo que altas concentrações do elemento geram efeitos tóxicos nas plantas. Entre outros efeitos têm-se: danificação do sistema radicular (TURINA, 1968), diminuição da atividade respiratória (MILLER et alii, 1970), distúrbios 
no processo de divisão celular (LEVAN, 1945), diminuição do teor de ferro, zinco e manganès nas folhas (FORSTER, 1954; CROOKE, 1955; WALLACE et alii, 1977a).

A toxidez de níquel, geralmente apresenta-se em solos áci dos derivados de rochas igneas ultrabāsicas, principalmente de serpentinas (MENGEL \& KIRKBY, 1982). Nos solos, o conteúdo de Ni depende da rea ção do material de origem, sendo menor à medida que aumenta a acidez das rochas. No Estado de São Paulo (Brasil) encontraram-se teores de Ni-total na faixa de 5 a $127 \mathrm{ppm}$, correspondendo os teores mais baixos aos solos derivados de sedimentos modernos arenosos, e os mais altos aos solos derivados de rochas básicas (ROVERS et aliì, 1983). Também, a toxidez de Ni é gerada pela aplicação excessiva de resîduos orgânicos industriais e urbanos no solo, devido a que esses resíduos podem conter altas concentrações de metais pesados ( $\mathrm{Pb}, \mathrm{Ni}, \mathrm{Zn}, \mathrm{Mn}, \mathrm{Cu}, \mathrm{Cr}, \mathrm{Cd}, \mathrm{Hg}, \mathrm{Fe}$ e Al). Assim, tem-se previsto a utilização de "lodo de esgoto" como adubo orgânico para diminuir o grau de poluição dos rios. BETTIOL et alii (1983) mencionam que o projeto de tratamento dos esgotos gerados na Grande São Paulo (SANEGRAN), tem planejado produzir em um futuro próximo aproximadamente 2400 toneladas diārias de lodo de esgoto rico em matēria orgânica e nutrientes. Desta forma, se estabelece um problema potencial relacionado com a toxidéz de $\mathrm{Ni}$, sendo necessärio avaliar seus efeitos nas culturas e conhecer seu comportamento no solo.

As considerações anteriormente expostas definem os objetivos da pesquisa, os quais são:

- Verificar os efeitos da toxidez de níquel nas culturas de arroz e feijão; 
- Avaliar a tolerância relativa à toxidez de níquel em duas variedades de arroz e em dois cultivares de feijão;

- Verificar o comportamento do níquel em solos de diferentes características;

- Avaliar os efeitos da calagem em solos ácidos, no controle da toxidez de níquel em arroz e feijão, e

- Descrever a sintomatologia característica da toxidez de Ni em plantas de arroz e de feijão. 


\section{REVISÃO DE LITERATURA}

\subsection{Propriedades Gerais do Níquel}

0 níquel faz parte do grupo VIII na tabela periódica de elementos (metais), junto ao ferro e cobalto. Apresenta alta densidade $\left(8,9 \mathrm{~g} / \mathrm{cm}^{3}, 25^{\circ} \mathrm{C}\right)$, nümero atômico igual a 28 , valência +2 e peso atômico de 58,71. Seu raio iônico $\left(\mathrm{Ni}^{2^{+}}=0,69 \AA\right)$, em função dos outros cátions predominantes nos solos, pode ser estabelecido na seguinte série: $\mathrm{NH}_{4}^{+}>\mathrm{K}^{+}>\mathrm{Ca}^{2+}>\mathrm{Mn}^{2+}>\mathrm{Fe}^{2+} \simeq \mathrm{Co}^{2+}>\mathrm{Mg}^{2+}>\mathrm{Ni}^{2+} \simeq \mathrm{Fe}^{3+}>\mathrm{Al}^{3+}>\mathrm{Si}^{4+}$.

$\mathrm{Na}$ natureza, têm sido encontrados 5 isótopos estáveis, sen do os mais predominantes: ${ }^{58} \mathrm{Ni}(68,3 \%),{ }^{60} \mathrm{Ni}(26,1 \%)$ e ${ }^{62} \mathrm{Ni}(3,6 \%)$. Forma complexos estäveis com grande número de ligantes orgânicos, e em menor grau com ligantes inorgânicos. Sob condições anaeróbicas, formas re duzidas de enxofre podem controlar a solubilidade do Ni (RICHTER \& THEIS, 1980). Normalmente ocorre nos estados de oxidação 0 e II. Pode substituir outros metais pesados nos sitios ativos de metaloenzimas, e assim inativar a sua função (ADRIANO, 1986). 
2.2. Niquel nos Solos

o nĩquel ocupa o vigésimo segundo lugar em abundância na crosta terrestre, com 99ppm (GREENWOOD \& EARNSHAW, 1984). Nas rochas ígneas, seu teor é maior nas ultrabásicas (1400 a 2000ppm), sendo que a concentração de $\mathrm{Ni}$ diminui com o aumento da acidez das rochas.

As rochas sedimentares apresentam teores na faixa de 5 a 90ppm, para rochas do tipo arenito e sedimentos argilosos respectivamente (KABATA-PENDIAS \& PENDIAS, 1986).

Geoquỉmicamente, o nỉquel (elemento siderófilo) encontrase associado com o ferro metālico. Também, apresenta uma grande afinidade pelo enxofre. Nos minerais ferro-magnesianos, pode substituir o ferro. Pode associar-se com carbonatos, fosfatos e silicatos. No processo de intemperismo de rochas é movimentado com facilidade para logo apös formar compostos com óxidos de Fe e Mn relativamente estáveis em so luções aquosas, e participar na formação de minerais secundários do tipo garnierita (KABATA-PENDIAS \& PENDIAS, 1986).

Os minerais de Ni, em função aos processos de origem, são de 2 tipos: (1) Lateritas, minerais óxido/silicatos como garnierita (Ni, $\mathrm{Mg})_{6} \mathrm{Si}_{4} \mathrm{O}_{10}(\mathrm{OH})_{8}$ e $\mathrm{Ni}-\mathrm{Fe}-1$ imonita $(\mathrm{Fe}, \mathrm{Ni}) \mathrm{O}(\mathrm{OH}) \cdot \mathrm{nH}_{2} \mathrm{O}$, os quais têm sido concentrados por processos de intemperismo em äreas tropicais chuvosas (Nova Caledônia, Cuba e Queensland); (2) Sulfetos, como a pentlandita ( $\mathrm{Ni}, \mathrm{Fe})_{9} \mathrm{~S}_{8}$ e associado ao $\mathrm{Cu}$, Co e metais preciosos, que são encontrados nas regiões temperadas (Canadā, URSS e África do Su1). Existem outros minerais de pouca importância como: niccolite, smaltite e arsenides (ADRIANO, 1986; HEESE, 1971). Nos materiais orgânicos do solo, o $\mathrm{Ni}$ encontra-se formando complexos (CROOKE, 1956). 


\subsubsection{Níquel tota1}

O teor de Ni nos solos, geralmente é muito baixo, menor de 100ppm (MENGEL \& KIRKBY, 1982). Os mais altos teores ocorrem em solos argilosos com rochas subjacentes básicas e vulcânicas, e em solos or gânicos com predominância de serpentina e turfa. Na superfície do solo, seu teor é reflexo dos processos de formação e do grau de poluição (KABATA-PENDIAS \& PENDIAS, 1986). Os valores de Ni-total nos solos do mundo são muito variāveis; VINOGRADOV (1959) reporta valores médios de 40ppm, enquanto que BERROW \& REAVES (1986) reportam valores de 25ppm.

Existem consideráveis variações no conteúdo de $\mathrm{Ni}$ em função do material de origem, sendo maior seu teor nos solos desenvolvidos de serpentina (ADRIANO, 1986) e menor nos solos derivados de granito e arenito (MITCHELL, 1945). Nos solos do Estado de São Paulo (Brasil), en controu-se que os solos derivados de rochas básicas apresentam os teores mais altos (52 e 127ppm), e os derivados de sedimentos modernos arenosos os mais baixos, menor que 20ppm (ROVERS et alii, 1983).

\subsubsection{Níquel extraíve1}

O Ni-extraível é utilizado como um índice para estabelecer sua disponibilidade e mobilidade no solo. Existem grandes variações nos seus valores em função ao agente extrator utilizado. Valores de Ni-extraỉvel, em porcentagem da concentração de Ni-total são: 0,5-2\% com DTPA(äcido dietileno-triaminopentacético) para solos Canadenses (WHITBY et alii, 1978), 3\% com NH4OAc-EDTA (acetato de amônio-ácido etileno-diaminotetracético) para solos Gregos poluidos (NAKOS, 1982), 
1,3-5,7\% com DTPA-TEA (ácido dietileno-triaminopentacético-trietanolamina) para solos do Suleste da Califórnia (VALADARES et alii, 1983) e 0,4-5\% com DTPA-TEA para solos de São Paulo-Brasil (ROVERS et alii, 1983). O Ni-extraỉvel com água é muito baixo, menor que 0,5\% da concentração de Ni-total (HAQ et alii, 1980). Existe uma excelente correlação entre o Ni-solúvel em DTPA-TEA e quantidades totais deste elemento adicionadas ao solo (VALADARES et alii, 1983). Nos solos de São PauloBrasil, os teores de Ni-solüvel em DTPA-TEA variam na faixa de $<0,5$ a 1,4ppm (ROVERS et alii, 1983).

\subsubsection{Formas de Ni nos solos}

Na fase sólida do solo, o Ni ocorre em muitas formas químicas que se apresentam no complexo de troca, locais de adsorção específica, adsorvido $\in$ ocluido nos sesquióxidos, fixado nos minerais de argila, e nos resỉduos orgânicos e microrganismos. Na fase líquida, solução solo, se apresenta na forma iônica e formando complexos com ligantes orgânicos e inorgânicos (ADRIANO, 1986).

Os modelos de estabilidade termodinâmica de sompostos con tendo $\mathrm{Ni}$, minerais e espécies iônicas, servem para explicar o comportamento do $\mathrm{Ni}$ no solo. Assim, os óxidos e hidróxidos de $\mathrm{Ni}$ são estáveis nos solos com valores de $\mathrm{pH}$ acima de 9, enquanto que o $\mathrm{Ni}$-ferrite $\left(\mathrm{NiFe}_{2} \mathrm{O}_{4}\right)$ parece ser a forma que predomina na fase sólida de solos com $\mathrm{pH}$ menor que 8. O fosfato de níquel $\left(\mathrm{Ni}_{3}\left(\mathrm{PO}_{4}\right)_{2}\right)$ é mais solúvel que o Ni-ferrite, portanto sua formação no solo depende da baixa disponibilidade de Fe. Também, nos solos que apresentam baixa atividade de $\mathrm{Fe}^{{ }^{+}}$, 
abaixo dos niveis da goethita, poderão formar-se aluminatos $\left(\mathrm{NiAl}_{2} \mathrm{O}_{4}\right)$ e silicatos $\left(\mathrm{Ni}_{2} \mathrm{SiO}_{4}\right)$. O Ni-sulfeto controla a concentração de $\mathrm{Ni}$ da solução do solo em ambientes reduzidos (SADIQ \& ENFIELD, 1984).

Na solução do solo, em função do pH, predominam as seguintes formas: $\mathrm{Ni}^{2+}, \mathrm{NiSO}_{4}$ e $\mathrm{NiHPO}_{4}$ a $\mathrm{pH}$ äcido; $\mathrm{Ni}^{2+}, \mathrm{NiCl}^{+}, \mathrm{NiSO}_{4}$ e $\mathrm{NiHPO}_{4}$ a $\mathrm{pH}$ menor que 7 ; e $\mathrm{Ni}^{2+}$ e $\mathrm{Ni}(\mathrm{OH})^{+}$em solos com $\mathrm{pH}$ maior que 8 (SADIQ \& ENFIELD, 1984). Formação de complexos com outros ânions são de pouca importância.

BLOOMFIELD (1981) encontrou que a matéria orgânica diminui o teor de Ni nos carbonatos, óxidos e argilas, O Ni forma complexos, na forma de quelados, com os compostos orgânicos do solo, sendo sua constante de estabilidade maior que a de outros metais. SCHNITZER \& KHAN (1978) estabelecem a seguinte série de estabilidade: $\mathrm{Ni}>\mathrm{Co}>\mathrm{Fe}>\mathrm{Cd}>\mathrm{Zn}>\mathrm{Mn}>\mathrm{Sr}$. A formação de quelados no solo é favorecida pela presença de ácidos orgânicos (CROOKE, 1956; MISRA \& PANDE, 1974). A capacidade de quelação da matéria orgânica tem sido calculada em 1,3 meq de $\mathrm{Ni} / \mathrm{g}$ de carbono orgânico (PRATT et alii, 1964). A presença de Ni formando parte de compos tos orgânicos ocorre principalmente nos horizontes superficiais do solo (BLOOMFIELD, 1981).

Com a utilização do programa de computador GEOCHEM(SPOSITO \& MATTIGOD, 1980), EMMERICH et alii (1982) determinaram as formas de $\mathrm{Ni}$ na solução de solos tratados com lamas de esgoto: 68\% na forma iônica li vre, 26,5\% na forma de complexos inorgânicos e $6 \%$ na forma de complexos orgânicos. 
2.2.4. Adsorção e complexação do Ni no solo

A disponibilidade de $\mathrm{Ni}$ para as plantas è regulada, em grande parte, pelas reações de adsorção que ocorrem entre o elemento e as superfícies sólidas do solọ. Estas reações podem ser controladas por diversos atributos do solo, tais como troca de cátions e pH (PAINTER et alii, 1953), matéria orgânica (KERNDORFF \& SCHNITZER, 1980), óxidos de aluminio e manganês (JENNE, 1968), teor de argila, porcentagem de $\mathrm{CaCO}_{3}$ e superfície específica (KORTE et alii, 1976; ESTAÑ et alii, 1985).

$0 \mathrm{Ni}$ é retido nos solos por mecanismos de adsorção especifica e não específica. Os mecanismos específicos ocorrem a baixas con centrações de Ni, menor que 10ppm (BOWMAN et alii, 1981). Dependendo da capacidade de adsorção do solo, a equação de Freundlich pode descrever a adsorção de $\mathrm{Ni}$ em concentrações maiores que 10ppm. POMBO et alii (1989) encontraram que as adsorções de $\mathrm{Ni}$ dos solos Terra Bruna Estruturada similar e Podzólico Vermelho Amarelo, aos diversos valores de pH estudados, obedeceram à equação de Langmuir. Em latossolos de São Paulo-Brasil, o Ni adicionado liga-se principalmente ao complexo de troca de forma não específica, sendo que sua adsorção máxima depende conjuntamente do $\mathrm{pH}$ e do teor de matéria orgânica do solo (CAMARGo et alii, 1989). Com parações feitas em solos, com valores de $\mathrm{pH}$ na faixa de 4,3 a 5,6, demonstram que os metais apresentam diferente capacidade de adsorção, na seguinte ordem: $\mathrm{Pb}>\mathrm{Cu}>\mathrm{Zn}>\mathrm{Ni}$ (HARTER, 1983). Por outro lado, avaliando a movimentação dos metais em colunas de solo ( $\mathrm{pH}$ de 3,8 a 7,1) encontrou-se: $\mathrm{Cd} \geq \mathrm{Ni} \geq \mathrm{Zn} \gg \mathrm{Cu}$ (TYLER \& McBRIDE, 1982). 
Este elemento forma complexos com uma grande variedade de ligantes orgânicos e inorgânicos, sendo os mais estāveis aqueles formados com ligantes orgânicos. Ocorre em menor grau a formação de complexos com ligantes inorgânicos na seguinte ordem: $\mathrm{OH}^{-}>\mathrm{SO}_{4}^{2-}>\mathrm{Cl}^{-}>\mathrm{NH}_{3}$ (RICHTER \& THEIS, 1980).

2.2.5. Fatores que afetam sua movimentação e disponibilidade

\section{$2.2 .5 .1 . \mathrm{pH}$}

Na maioria dos metais pesados, a solubilidade e disponibilidade estão inversamente relacionadas com os valores de $\mathrm{pH}$ do solo. - Em solos ácidos, a disponibilidade de $\mathrm{Ni}$ para as plantas aumenta (MISHRA \& KAR, 1974). Em estudos de adsorção de $\mathrm{Ni}$, foi verificado que a retenção de $\mathrm{Ni}$ no solo aumenta com o pH (HARTER, 1983). Do mesmo modo, o pH influencia a reação de $\mathrm{Ni}$ com outros compostos para formar precipitados. Em solos com $\mathrm{pH}$ alcalino formam-se fosfatos de níquel, reduzindo sua dis ponibilidade (PRATT et alii, 1964).

As concentrações crîticas de $\mathrm{Ni}$ no solo, são afetadas pe$10 \mathrm{pH}$, sendo menores nos solos ácidos, em comparação aos solos alcalinos. Utilizando trigo como planta indicadora, o teor de Ni que reduz o rendimento em 50\% foi de 195ppm em solos ácidos e 510ppm de $\mathrm{Ni}$ em solos alcalinos (MISHRA \& KAR, 1974).

A calagem de solos äcidos controla a fitotoxidez de $\mathrm{Ni}$ (ADRIANO, 1986). Porém, valores de pH acima de 8 não eliminam a fitotoxidez (SOANE \& SAUNDER, 1959). 
2.2.5.2. Matēria orgânica

A matéria orgânica, em função de sua natureza, pođe imobilizar ou mobilizar metais no solo. Algumas pesquisas mostram sua capacidade para fixar $\mathrm{Ni}$, diminuindo sua disponibilidade (HALSTEAD, 1968; HALSTEAD et alii, 1969). Em solos derivados de serpentina é comum a adição de resíduos orgânicos para aumentar a capacidade de adsorção de metais no solo e diminuir sua disponibilidade (MISHRA \& KAR, 1974).

Tambēm, a matéria orgânica pode formar complexos solüveis com o Ni, quelados, principalmente os ácidos fülvicos. Estes complexos aumentam sua estabilidade com o aumento do $\mathrm{pH}$ (SCHNITZER \& SKINNER, 1968). Nos processos de decomposição da matēria orgânica, são produzidos ácidos orgânicos por ação microbiana, ācidos di e tricarboxílicos, que podem atuar como agentes quelantes e formar complexos com o $\mathrm{Ni}$ (MISRA \& PANDE, 1974).

A matéria orgânica influencia o padrão de distribuição do Ni no perfil do solo. Assim, nos solos orgānicos de ecossistemas florestais o teor de $\mathrm{Ni}$ é maior na superfície, enquanto que em podzóis o teor de Ni aumenta ligeiramente com a profundidade (CONNOR etalii, 1957).

A aplicação de lodos de esgoto no solo, como fonte de matéria orgânica e nutrientes, tem restrições devido ao seu alto conteúdo de metais pesados. $0 \mathrm{Ni}$ presente nas lamas (16 a 5300ppm), encontra-se principalmente na forma de quelados, sendo rapidamente disponivel para as plantas e gerando fitotoxidez (BERROW \& WEBBER, 1972). 
2.2.5.3. Textura e material de origem

O teor de $\mathrm{Ni}$ nas frações do solo varia inversamente ao ta manho das partículas (LE RICHE \& WEIR, 1963). O papel da argila no comportamento do Ni no perfil do solo é ressaltado devido à correlação positiva existente entre a quantidade de Ni-total e o teor de argila. A influência da argila deve-se a sua capacidade para adsorvê-1o ou mesmo contê-1o em suas próprias estruturas (JENNE, 1968; ROVERS et alii , 1983).

Também, o material de origem influencia o teor de $\mathrm{Ni}$ no solo. MITCHELL (1945) encontrou mais $\mathrm{Ni}$ nos solos derivados de sedimentos argilosos e rochas básicas (50 a 500ppm), do que nos solos derivados de arenitos, calcários e rochas ígneas ácidas (1 a 50ppm). Nos soḷos de São Paulo-Brasil, ROVERS et alii (1983) constataram que o material de origem foi fator preponderante no condicionamento dos teores de Ni-to tal. Solos derivados de rochas ígneas básicas apresentam teores maiores do que solos derivados de sedimentos arenosos. A presença de ferro é responsāvel pela fixação de $\mathrm{Ni}$, controlando assim sua movimentação e dis ponibilidade no solo (JENNE, 1968).

\subsection{Niquel nas Plantas}

2.3.1. Níquel na nutrição das plantas

O Ni é absorvido pelas raỉzes das plantas na forma iônica $\left(\mathrm{Ni}^{2+}\right.$ ) e complexado como quelado (CROOKE, 1954). MISHRA \& KAR (1974) observaram que a absorção radicular do $\mathrm{Ni}$ foi, principalmente na forma iônica. A dificuldade na absorção de formas queladas, poderia dever-se a um efeito de carga. 
Na planta, o Ni é muito móvel, sendo que nos casos de deficiência sua redistribuição è rāpida (MISHRA \& KAR, 1974; CATALDO et alii, 1978). Na etapa de senescência de plantas de soja, 70\% do $\mathrm{Ni}$ da parte aérea redistribui-se às sementes (CATALDO et alii, 1978). É transportado pelo xilema como cátion e complexo orgânico. A forma de transporte depende da espécie vegetal. Em tomateiro a maior proporção ē translocada como cátion, enquanto que milho, cenoura, aböbora e amendoim transportam o Ni como um complexo carregado negativamente (TIFFIN, 1971). No floema, sua movimentação é na forma de complexos orgânicos (MISHRA \& KAR, 1974).

Nos processos ativos de absorção, o Ni apresenta isotermas multifásicas (cinética Michaelis-Menten), que indicam a existência de värios carregadores operando em diferentes faixas de concentração do elemento (CATALDo et alii, 1978). Também, existe inibição competitiva na absorção do $\mathrm{Ni}^{2+}$ pelo $\mathrm{Cu}^{2+}$ e $\mathrm{Zn}^{2+}$ (ADRIANO, 1986).

A acumulação do Ni na planta faz-se diferentemente, sendo maior nas folhas que nos ramos, nos grãos que nas folhas, e nas partes jovens que nas partes adultas (HUNTER \& VERGNANO, 1952). A nível celular, maiormente acumula-se no fluido vacuolar e nos plastídios (GOLOVCHENKO \& CHEREDNICHENKO, 1962).

VANSELOW (1965) reporta teores na faixa de 0,05 a 5ppm na matëria seca, enquanto COTTENIE et alii (1979) encontraram teores de Ni em plantas normais superiores a 8ppm. Na parte aérea do feijoeiro, WALLACE et alii (1977a) verificaram teores de 2 a $5 \mathrm{ppm}$, enquanto que, na parte aérea do arroz, WALLACE et alii (1977b) observaram teores de 2 a $20 \mathrm{ppm}$, em plantas normais. 
2.3.2. Efeitos benéficos do $\mathrm{Ni}$ no desenvolvimento das plantas

Muitas pesquisas mostram que o $\mathrm{Ni}$ a baixas concentrações pode atuar como nutriente em plantas. Este elemento é exigido para o normal desenvolvimento de espécies de Pinus e outras espécies acumuladoras (Alyssum), sendo sua função especĩfica desconhecida (WELCH, 1981).

Os efeitos de sua deficiência tem sido mostrados em vārias espécies. Em leguminosas, gera acumulação de uréia nos tecidos, pro vocando lesões necróticas nas folhas (ESKKEW et alii, 1983; WALKER et alii, 1985). O Ni participa na estrutura e funcionamento da enzima urease, 6 a 8 átomos de Ni por molécula, cuja função é evitar a acumulação de uréia nas folhas (DIXON et alii, 1975; SHIMADA et alii, 1980). A urease se apresenta em numerosas espécies de plantas (WELCH, 1981). A uréia é um produto do metabolismo de nitrogênio nas plantas, sendo que o $\mathrm{Ni}$ favorece a atividade da urease que cataliza a hidrölise da uréia a $\mathrm{CO}_{2}$ e $\mathrm{NH}_{3}$ (ESKEW et alii, 1983). WELCH (1981) e THOMAS \& SCHRADER (1981) explicam que as leguminosas de clima tropical são mais dependentes do $\mathrm{Ni}$, devido a que a maior parte do nitrogênio fixado (80 a 95\%) é transportado à parte aérea como ureídos (alantoína e àcido alantóico), onde participam no desenvolvimento de vagens e sementes. Na via catabólica, estes ureỉdos sofrem degradação enzimática a uréia e ácido glioxílico (WELCH, 1981). Em plantas de pepino e cevada, WATANABE \& SHIMADA (1990) verificaram que o Ni participa no metabolismo do nitrogênio destas espécies, formando parte da enzima urease.

Em cereais como cevada, a deficiência de Ni afeta principalmente a viabilidade das sementes, portanto se reduz a taxa 
de germinação (BROWN et alii, 1987). Também existe um efeito na senescência de folhas e flores em cereais, niveis de $\mathrm{Ni}$ na faixa de 500 $\mathrm{M}$ a $2 \mathrm{mM}$ na solução nutritiva retardam a senescência, por ser um inibidor da sintese do S-adenosylmetionina, precursor do etileno (LAU \& YANG, 1976).

Os efeitos benéficos do Ni na germinação de sementes, poderiam estar relacionados a atividade da urease na germinação e com a economia de nitrogênio de plântulas em desenvolvimento de vārias famílias (WELCH, 1981). Outro efeito é sua influência na atividade do complexo enzimático hidrogenase, que aumenta a eficiência da fixação de nitrogênio em leguminosas (KLliCAS et alii, 1983). Também, o Ni participa na sỉntese de fitoalexina que melhora a resistência das plantas às doen çàs (WALKER et alii, 1985), favorece a formação de vitamina $\mathrm{P}^{3}$ nos gêneros Phaseolus, Pisum e Lactuca (LO \& WU, 1943; LO \& CHEN, 1946), estimula o crescimento de batata, aveia, videira e pastagens (HUTCHINSON, 1981), e sua absorção $\left(\mathrm{Ni}^{2+}\right)$ pode favorecer a extrusão de protons nas raỉzes de milho (COCUCCI \& MORGUTTI, 1986).

\subsubsection{Interações do $\mathrm{Ni}$ com outros elementos}

Muitas pesquisas tem demonstrado que $\mathrm{O}$ Ni se relaciona com outros elementos gerando efeitos sinérgicos e antagônicos na planta. Na maioria das espécies de plantas, a absorção e translocação de Ni é inibida pela presença de $\mathrm{Ca}^{2+}, \mathrm{Mg}^{2+}, \mathrm{Fe}^{2+}$ e $\mathrm{Zn}^{2+}$, sendo que altos níveis de $\mathrm{Ni}$ no meio induzem deficiência de zinco e ferro (ANDERSON et alii, 1973). Em soja, a absorção è translocação de $\mathrm{Ni}$ é inibida por $\mathrm{Cu}^{2+}$, $\mathrm{Zn}^{2+}, \mathrm{Fe}^{2+}$ e $\mathrm{Co}^{2+}$ (MISHRA \& KAR, 1974; CATALDO et alii, 1978). A inibição da absorção radicular de $\mathrm{Ni}^{2+}$ pelo $\mathrm{Cu}^{2+}$ e $\mathrm{Zn}^{2+}$ é do tipo competitiva. 
Também, utilizando métodos isotópicos $\left({ }^{59} \mathrm{Fe}\right)$, confirmou-se que o $\mathrm{Ni}$ inibe a absorção e translocação de Fe (CHINO \& MITSUI, 1967).

Existem efeitos aditivos do $\mathrm{Ni}$ e $\mathrm{Cu}$, que podem causar deficiência de ferro nas plantas, por inibição de sua translocação à parte aérea (FOY et alii, 1978). No tomateiro, este efeito pode diminuir o crescimento da planta, o desenvolvimento das raízes e o conteúdo de clorofila nas folhas (HALE et alii, 1985). Outro efeito aditivo: Fe-Ni, inibe a absorção e transporte de $\mathrm{Zn}$ e Mn nas folhas e caules de feijão (WALLACE et alii, 1977a).

Outras pesquisas, demonstram efeitos antagōnicos do Ni com o molibdênio (SATO, 1969) e o cobalto (RUSSELl et alii, 1968). Em tomateiro e batata o excesso de $\mathrm{Ni}$ provoca uma deficiência aparente de manganês (HEWITT, 1953). Alguns efeitos sinérgicos do Ni são: aumento da absorção de Ca em aveia e tomateiro (CROOKE, 1958), de Cu em tomateiro (HALE et alii 1985), e de Cr em espécies de silene (SHEWRY PETERSON, 1976).

\subsubsection{Toxidez de Ni e seu controle}

Em geral, a toxidez de $\mathrm{Ni}$ se expressa quando a concentração de Ni na matēria seca das plantas for maior que 50ppm, com exceção das espécies acumuladoras e hiperacumuladoras (ADRIANNO, 1986). MISHRA \& KAR (1974) encontraram em ensaios em solução nutritiva, que o Ni é tóxico a nỉveis de 1 a 300ppm, dependendo das espécies de plantas. Na matéria seca da parte aérea das plantas, foram encontrados os seguintes nỉveis töxicos, em ppm: arroz, 20-50 (CHINO, 1981); cevada, 26 (DAVIS 
et alii, 1978); espécies florestais, 100-150 (LOZANO \& MORRISON, 1981); cítricos, 55-140 (VANSELOW, 1951) e cafeeiro, 30-70 (PAVAN \& BINGHAM, 1982) .

HUNTER \& VERGNANO (1953) determinaram que aplicações excessivas de metais pesados nas plantas, produzem a sintomatologia típica da deficiência de ferro, além da sintomatologia específica ao metal. Apa rentemente o $\mathrm{Ni}$ interfere na absorção de $\mathrm{Fe}$ e inibe o seu metabolismo (AGARWALA et alii, 1977). Outros efeitos dos excessos são: bloqueio da ativiảade respiratöria e desnaturação do protoplasma celular em repolho (NIETHAMMER, 1931), aumento do conteūdo de pectina em raízes de aveia (CROOKE, 1958), diminuição da concentração de clorofila em folhas de café (PAVAN \& BINGHAM, 1982), diminuição da atividade da catalase ao concorrer com o $\mathrm{Fe}$ na sua posição no grupo protoporfirínico da enzima (GRANICK, 1951), aumento da atividade da peroxidase e distūrbios mitóticos nas pontas das raỉzes de algumas plantas (MISHRA \& KAR, 1974), interfere na absorção de nutrientes (CROOKE \& INKSON, 1955), e produz a plasmólise em células epidérmicas de cebola (NIETHAMMER, 1931).

As relações $\mathrm{Fe} / \mathrm{Ni}$ e $\mathrm{Cu} / \mathrm{Ni}$ na matéria seca das plantas, po dem ser usadas como indicadores do grau de tolerância à toxidez de $\mathrm{Ni}$, nas culturas que se desenvolvem sobre solos derivados de serpentina (MIZUNO, 1968). Assim, culturas com relações $\mathrm{Fe} / \mathrm{Ni} \geq 5$ e $\mathrm{Cu} / \mathrm{Ni} \geq 1$ foram tolerantes (batata e milho), enquanto que culturas com relações $\mathrm{Fe} / \mathrm{Ni}<5$ e $\mathrm{Cu} / \mathrm{Ni}<1$ foram muito susceptiveis (soja, feijão, repolho e alfafa). 
Em solos derivados de rochas ultrabásicas, serpentina e peridotita, a toxidez de $\mathrm{Ni}$ pode ser controlada pela calagem (HUNTER \& VERGNANO, 1952; CROOKE, 1956) e aplicações de matéria orgânica (KABATAPENDIAS \& PENDIAS, 1986). A calagem nestes solos reduz a solubilidade de $\operatorname{Cr}$ e Ni na solução do solo com o aumento do $\mathrm{pH}$, além de melhorar as relações desfavoráveis de $\mathrm{Mg} / \mathrm{Ca}$. Adições de gipsita ao solo, não controlam a toxidez de Ni (MISHRA \& KAR, 1974), enquanto que aplicações de fosfato podem diminuir a disponibilidade de $\mathrm{Ni}$ para as plantas (KABATAPENDIAS \& PENDIAS, 1986).

\subsubsection{Plantas acumuladoras e hiperacumuladoras}

Em meio ambiente com solos derivados de rochas ultrabäsicas, existem espécies acumuladoras e hiperacumuladoras de Ni. Espécies acumuladoras são aquelas que apresentam na sua matéria seca concentrações elementares de $\mathrm{Ni}$ maiores a outras espécies de plantas associadas a substratos normais (SAVERNE, 1974). Enquanto que espécies hiperacumuladoras são aquelas que apresentam altas concentrações de $\mathrm{Ni}$ na sua matéria seca, sendo que esta concentração excede em 10 vezes os maiores valores observados para espécies de plantas que se desenvolvem sobre substrato ultrabásico (BROOKS et alii, 1977). Nas folhas de espécies hiperacumuladoras, a concentração de $\mathrm{Ni}$ na matēria seca é maior que $1000 \mathrm{ppm}$. Muitas espécies hiperacumuladoras pertencem às famílias: Boraginaceae, Cruciferae, Myrtaceae, Leguminosae e Cariofilaceae (KABATA-PENDIAS \& PENDIAS, 1986). Algumas espécies são: Sebertia acuminata, Hybanthus flo ribundus, Alyssum bertholonii, Alyssum corsicum, Homaltium kanaliense, Pimelea suteri e Eremophila exilifolia. 
A capacidade das plantas para acumular Ni no seu tecido pode estar relacionada com o conteúdo de äcido cítrico de suas folhas. Anālises da seiva mostram a presença de $\mathrm{Ni}$ acomplexado com o citrato (LEE et alii, 1978). BROOKS (1980) justifica o interesse por estas espécies de plantas, nos programas de recuperação de solos derivados de serpentina, solos que são inadequados para sustentar uma vegetação normal.

\subsubsection{Sintomatologia da deficiência e toxidez de $\mathrm{Ni}$}

A sintomatologia da deficiência é descrita em vārias culturas. A soja apresenta lesões necróticas na ponta de suas folhas novas, nessas lesões é alta a concentração de uréia, 2,5\% em peso seco (SHIMADA et alii, 1980; ESKEW et alii, 1984). Em caupi (Vigna ungiculata L.), formam-se pontos necróticos nas folhas durante a etapa reprodutiva (WALKER et alii, 1985). SHIMADA et alii (1980) reportam pa ra tomateiro, sintomatologia de deficiência semelhante à apresentada em soja, enquanto que BROWN et alii (1987) descrevem a deficiência como aparecimento de clorose nas folhas mais novas e posterior necrose do tecido meristemätico. Em cereais (cevada, aveia e trigo), também se apresentam lesões necróticas nas folhas mais novas, podendo-se sugerir que o Ni é praticamente imōvel no floema quando a planta é deficiente de Ni (BROWN et alii, 1987). A sintomatologia em aveia inclui o desenvolvimento incompleto das folhas e a senescência prematura da planta (BROWN et alii, 1987). 
A sintomatologia da toxidez de $\mathrm{Ni}$, se apresenta como clorose e posterior necrose de folhas, começando pelas folhas novas. Nas gramineas, consiste em clorose ao longo das nervuras, sendo que a folha inteira pode ficar eșbranquiçada, semelhante aos sintomas de carência de ferro, e, em casos extremos, há necrose nas margens e reảução no crescimento (HEWITT, 1953). Em sorgo, CLARK et alii (1981) encontraram que os sintomas de toxidez de $\mathrm{Ni}$ são semelhantes aos ocasionados pelo excesso de Co e pela deficiência de Fe. Em arroz, se apresenta como clorose internerval nas folhas novas, sendo que o número de folhas, perfilhos e raỉzes diminui (CHINO, 1981). Em geral, as raízes são curtas e grossas, coraloides, de cor escura e quebradiças. Nas dicotiledôneas aparece uma clorose internerval nas folhas novas que lembra a deficiência de manganês (HEWITT, 1953; MALAVOLTA, 1980), as raỉzes se apresentam curtas, de cor escura e quebradiças. Em mudas de café, o.s sintomas foram caracterizados inicialmente por clorose e muitos pontos necróticos nas folhas jovens, que progridem rapidamente para folhas mais velhas, e nos internódios. Em estádios mais adiantados da toxidez as plantas apresentam, além dos sintomas acima descritos, diminuição no tamanho das folhas e entrenós, manchas necróticas nos pecỉolos das folhas e caules, desfolhamento e fenecimento (PAVAN \& BINGHAM, 1982). 
3. MATERIAL E METODOS

O trabalho foi realizado nas instalações da Seção de $\mathrm{Nu}-$ trição de Plantas, Centro de Energia Nuclear na Agricultura (CENA), Universidade de São Paulo - Campus de Piracicaba, nos anos de 1987 a 1990.

3.1. Cultivares ou variedades utilizadas

Em feijão (Phaseolus vulgaris L.), utilizou-se os cultivares Carioca e IAPAR-14. Enquanto que, em arroz (Oriza sativa L.) utilizou-se as variedades IAC-165 e IAC-4440, cedidas pelo Departamento de Sementes da Escola Superior de Agricultura "Luiz de Queiroz", Universidade de São Paulo.

3.2. Ensaios em solução nutritiva

\subsubsection{Procedimento geral}

- Desinfecção das sementes por meio de lavagem com solução de hipoclorito de sódio diluỉdo em água destilada, na proporção $1: 10$. 
- Germinação das sementes em vermiculita umedecida com so lução de $\mathrm{Ca} \mathrm{SO}_{4} \cdot 2 \mathrm{H}_{2} \mathrm{O} 10^{-4} \mathrm{M}$. Após a emergência de plântulas de arroz e feijão, continuou-se adicionando sulfato de cálcio $10^{-4} \mathrm{M}$, toda vez que a superfície do meio mostrou-se seca.

- Transplante de plântulas com 10 e 15 dias de idade, feí jâo e arroz respectivamente, para bandejas com capacidade de 30 litros de solução nutritiva, Solução № 2 de HOAGLAND \& ARNON (1950), diluîda $1 / 5$ da concentração usual. Sistema mantido sob arejamento constante.

- Após permanecerem 10 dias na bandeja com solução nutritiva diluída, as plântulas de feijão è arroz foram submetidas aos tratamentos de níquel, com o transplante para vasos de plástico de 1,5 \& decapacidade e fixandoas com espuma de plástico, duas plantas por vaso.

\subsubsection{Tratamentos}

Os tratamentos foram estabelecidos nos vasos de plástico de $1,5 \ell$ de capacidade. Níveis crescentes de níquel em Solução Nutritiva No 2 de HOAGLAND \& ARNON (1950). O níquel foi adicionado como $\mathrm{Ni}\left(\mathrm{NO}_{3}\right)_{2} \cdot 6 \mathrm{H}_{2} \mathrm{O}$. Os micronutrientes foram fornecidos por meio da solução "a" e, o ferro como Fe-EDTA (MALAVOLTA, 1979). O pH da solução foi ajus tado semanalmente na faixa de 4,5 a 5,5 com $\mathrm{HCl}$ ou $\mathrm{NaOH} 0,1 \mathrm{~N}$. A solução nutritiva com os niveis de $\mathrm{Ni}$ foi renovada cada duas semanas e seu volume mantido com adições de água desionizada. 
3.2.2.1. Ensaio 1. Estabelecimento dos níveis de $\mathrm{Ni}$ a serem utilizados

Culturas

Feijão, cultivar Carioca

Arroz, variedade IAC-165
$\underline{\mathrm{Ni}(\mathrm{ppm})}$

0

1

2

4

8

16

2 culturas $\times 6$ niveis de $\mathrm{Ni}=12$ tratamentos

12 tratamentos $\times 3$ repetições $=36$ unidades experimentais.

3.2.2.2. Ensaio 2. Avaliação da toxidez de $\mathrm{Ni}$ em feijão

Cultivar

$\mathrm{Ni}(\mathrm{ppm})$

Carioca

0

1

2

4

4 tratamentos $\times 3$ repetições $=12$ unidades experimentais. 
3.2.2.3. Ensaio 3. Avaliação da toxidez de $\mathrm{Ni}$ em dois cul tivares de feijão

Cultivares

Carioca

IAPAR -14
Epocas de Coleta.

Floração

Formação de grãos
$\underline{\mathrm{Ni}(\mathrm{ppm})}$

0

1

2

4

2 cultivares $\times 2$ épocas de coleta x 4 níveis de $\mathrm{Ni}=16$ tratamentos 16 tratamentos $\mathrm{x} 3$ repetições $=48$ unidades experimentais

3.2.2.4. Ensaio 4. Avaliação da toxidez de $\mathrm{Ni}$ em duas variedades de arroz

$\underline{\text { Variedades }}$

IAC -165

IAC -4440 $\underline{\text { Epocas de Coleta }}$

Perfilhamento

Formação de grãos
$\underline{\mathrm{Ni}(\mathrm{ppm})}$

0

4

8

12

2 variedades $\mathrm{x} 2$ épocas de coleta $\mathrm{x} 4$ níveis de $\mathrm{Ni}=16$ tratamentos

16 tratamento $\times 3$ repetições $=48$ unidades experimentais 


\subsection{Ensaios em solos}

\subsubsection{Solos utilizados}

Foram utilizados três solos, provenientes da camada $0-20 \mathrm{~cm}$ de profundidade, que correspondem a Latossolo Roxo distrófico (LRd), Terra Roxa Estruturada (TE) e Vertissolo (V). Os resultados das análises físico-quimicas que incluem Ni-total, se apresentam na Tabela 1.

Tabela 1. Características físicas e químicas dos solos

\begin{tabular}{lccc}
\hline & $\mathrm{V}$ & $\mathrm{LRd}$ & $\mathrm{TE}$ \\
\hline $\mathrm{pH}, \mathrm{CaCl} 2$ & 5,4 & 4,9 & 4,7 \\
$\mathrm{M} . \mathrm{O}(\%)$ & 6,05 & 3,53 & 2,42 \\
$\mathrm{P}\left(\mathrm{Hg} / \mathrm{cm}^{3}\right)$ & 69,1 & 30,6 & 10,3 \\
$\mathrm{~K}^{+}\left(\mathrm{meq} / 100 \mathrm{~cm}^{3}\right)$ & 0,14 & 0,55 & 0,17 \\
$\mathrm{Ca}^{2+}\left(\mathrm{meq} / 100 \mathrm{~cm}^{3}\right)$ & 22,49 & 2,59 & 1,62 \\
$\mathrm{Mg}{ }^{2+}\left(\mathrm{meq} / 100 \mathrm{~cm}^{3}\right)$ & 4,88 & 1,02 & 0,57 \\
$\mathrm{Al}{ }^{3+}\left(\mathrm{meq} / 100 \mathrm{~cm}^{3}\right)$ & 0,18 & 0,24 & 0,36 \\
$\mathrm{Al}{ }^{3+}+\mathrm{H}^{+}\left(\mathrm{meq}^{3} / 100 \mathrm{~cm}^{3}\right)$ & 4,23 & 5,80 & 3,81 \\
$\mathrm{~S}$ & 27,51 & 4,16 & 2,36 \\
$\mathrm{~T}$ & 31,74 & 9,96 & 6,17 \\
$\mathrm{~V}(\%)$ & 86,7 & 41,8 & 38,2 \\
$\mathrm{Ni}-\mathrm{total} \mathrm{(ppm)}$ & 49 & 41 & 43 \\
$\mathrm{Areia}(\%)$ & 27,9 & 17,0 & 23,5 \\
$\mathrm{Limo}(\%)$ & 38,9 & 17,0 & 29,5 \\
$\mathrm{Argila}(\%)$ & 33,2 & 66,0 & 47,0 \\
\hline
\end{tabular}


3.3.2. Procedimento geral

- Peneirar os solos (TFSA) com malha de $2 \mathrm{~mm}$, e colocar em vasos de barro, impermeabilizados com Neutrol, com capacidade de $1,2 \mathrm{Kg}$.

- Nos ensaios que avaliam a resposta da calagem (Ensaios 7 e 8), aplicou-se $\mathrm{Ca}(\mathrm{OH})_{2}$ para elevar a saturação de bases de cada solo (LRd e TE) a 65 e 70\%, para as culturas de arroz e feijão respectivamente. Também, adicionaram-se os tratamentos de nỉveis crescentes de niquel como $\mathrm{Ni}\left(\mathrm{NO}_{3}\right)_{2} \cdot 6 \mathrm{H}_{2} \mathrm{O}$.

- Após a aplicação dos tratamentos nos solos, incubou-se os mesmos por 4 semanas, mantendo a umidade a $70 \%$ da ca pacidade de campo. No final da incubação, foram retiradas amostras de todos os tratamentos para analisar o teor de Ni-solúvel em DTPA-TEA.

- Desinfecção das sementes de arroz e feijão, por meio de lavagem com solução de hipoclorito de sódio, diluỉda em āgua destilada, na proporção $1: 10$.

- Logo após a incubação dos tratamentos, realizou-se a semeadura direta de 5 sementes por vaso, e aplicou-se os nutrientes necessários em solução: 150ppm de $\mathrm{N}$ e $\mathrm{K}$, 200ppm de P, 30ppm de Mg, 5ppm de Mn, 2ppm de Zn, 1ppm de $B, 0,5 p p m$ de $\mathrm{Cu}$ e 0,1ppm de Mo. $\mathrm{N}$ e $\mathrm{K}$ fracionado em 3 etapas. Uma semana depois da germinação desbastou-se deixando duas plantas por vaso. 
- Tambēm, após a colheita dos ensaios, foram retiradas amostras de solos para analisar o teor de Ni-solüvel em DTPA-TEA. Tempos de incubação: 28,138 (após colheita de feijão) e 222 dias (após colheita de arroz)

\subsubsection{Tratamentos}

Os tratamentos foram estabelecidos nos vasos de barro com 1,2 Kg de capacidade. Avaliação dos efeitos da toxidez de níquel nas culturas de arroz e feijão, e seu controle pela calagem. Os níveis cres centes de níquel utilizados foram: $0,30,60$ e $120 \mathrm{ppm}$ de Ni. No feijão utilizou-se o cultivar Carioca, enquanto que no arroz foi utilizada a variedade IAC-165. A colheita destes ensaios foi feita na época de formação de grãos.

3.3.3.1. Ensaio 5. Avaliação da toxidez de $\mathrm{Ni}$ em 3 solos na cultura de feijão

Solos.

$\mathrm{V}$

LRd

$\mathrm{TE}$
Ni (ppm)

30

60

120

3 solos $\times 4$ niveis de $\mathrm{Ni}=12$ tratamentos

12 tratamentos $\mathrm{x} 3$ repetições $=36$ unidades experimentais 
3.3.3.2. Ensaio 6. Avaliação da toxidez de $\mathrm{Ni}$ em 3 solos na cultura de arroz

$\underline{\text { Solos }}$

$\mathrm{V}$

LRd

TE

3 solos $\times 4$ niveis de $\mathrm{Ni}=12$ tratamentos

12 tratamentos $\mathrm{x} 3$ repetições $=36$ unidades experimentais

3.3.3.3. Ensaio 7. Avaliação da resposta a calagem do so lo no controle da toxidez de $\mathrm{Ni}$ em feijão

Solos

LRd

$\mathrm{TE}$

Calagem

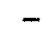

$+$

60

120

2 solos $\mathrm{x}$ calagem (2) $\times 4$ nỉveis de $\mathrm{Ni}=16$ tratamentos

16 tratamentos $\times 3$ repetições $=48$ unidades experimentais 
3.3.3.4. Ensaio 8. Avaliação da resposta a calagem do so 1o no controle da toxidez de $\mathrm{Ni}$ em arroz

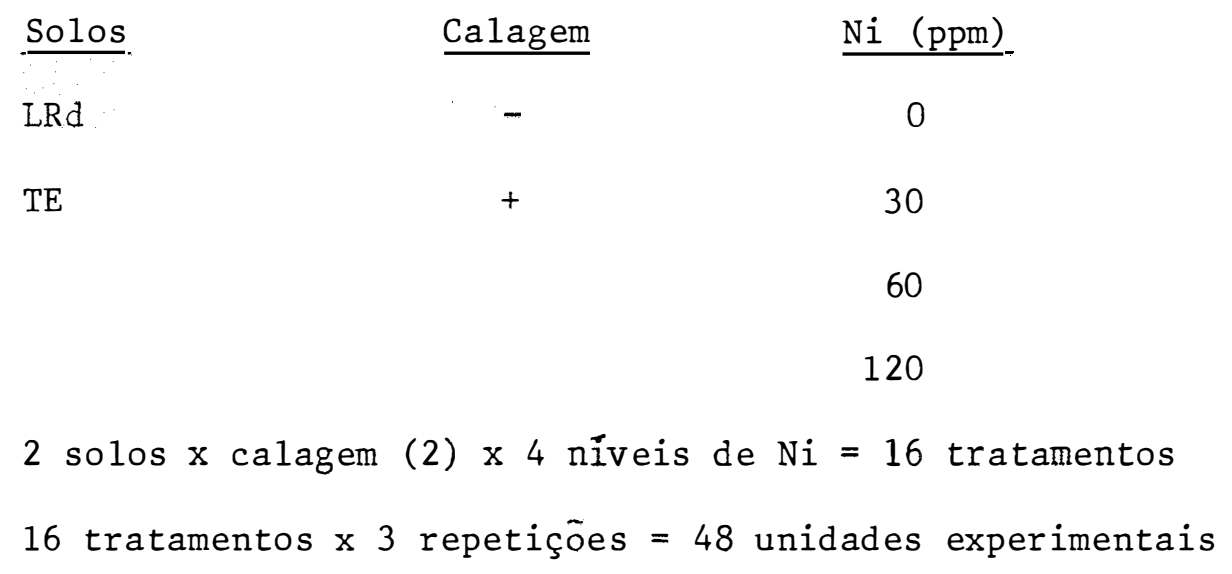

3.4. Anālise do teor de clorofila total

Foram feitas análises de clorofila total nas etapas de floração (feijão) e perfilhamento (arroz), dos ensaios em solução nutritiva Nọ. $2(3.2 .2 .2), 3(3.2 .2 .3)$ e $4(3.2 .2 .4)$. Coletou-se amostras de tecido fresco de folhas de idade média, e utilizou-se o método descrito em ASSOCIATION OF OFFICIAL AGRICULTURAL CHEMIST (1950).

\subsection{Estudos de Microscopia Eletrônica}

- Amostragem: Foram retiradas com auxílio de lâmina de barbear pequenos fragmentos de folhas intermediārias de feijão cv.Carioca e arroz var. IAC-165, tratados com 4 e 8ppm de $\mathrm{Ni}$, respectivamente, por um tempo de 3 semanas sob efeito de $\mathrm{Ni}$, além da testemunha (sem Ni). As amostras foram imediatamente conduzidas ao Laboratório de Microscopia do CENA, para realizar o preparo do material. 
- Tratamento: Fixação, com glutaraldeido 5\% em tampão fosfato $0,2 \mathrm{M} \mathrm{pH} 7,2$ por 1 hora a $4^{\circ} \mathrm{C}$; Pós-fixação, em solução de tetróxido de osmio $2 \%$ em tampão fosfato $0,2 \mathrm{M}$ por 1 hora a $4{ }^{\circ} \mathrm{C}$; Pré-coloração, com acetato de uranilo $2,5 \%$ em ägua bidestilada $4^{\circ} \mathrm{C}$ por noite; Desidratação das peças, em gradientes de concentração crescentes de acetona: água de 25, 50, 75 (5 minutos em cada etapa), 90 (10 minutos) e 100\% (20 minutos); Infiltração das peças, com a resina Epon 912 em 3 etapas (resina: acetona): 50, 75 e 100\% de resina, as duas primeiras por 3 horas a $37^{\circ} \mathrm{C}$ e a $\bar{u} 1$ tima $4^{\circ} \mathrm{C}$ por noite; Inclusão das peças em moldes de borracha preenchidas com resina, em estufas de 37,45 e $60^{\circ} \mathrm{C}$ durante 8, 16 e 24 horas, respectivamente, a fim de obter os blocos.

- Preparo do espécime para Microscopia, cortes ultrafinos $(60-90 \mathrm{~nm})$ foram coloridos com acetato de uranila 2,5\% em água por 10 minutos, lavados 60 vezes com água bidestilada, e coloridos com citrato de chumbo por 6 minutos e novamente lavados com água bidestilada. Os cor tes foram examinados com microscópio eletrônico Zeiss operando a 60.000 volts.

3.6. Colheita e preparo do material para anālise

- As plantas de feijão, coletadas por ocasião da floração foram separadas em raiz, caule + ramo e folha, enquanto que, as plantas coletadas no momento da formação de grãos, foram separadas em raiz, caule + ramo, folha, casca e grão.

- As plantas de arroz, coletadas por ocasião do máximo per filhamento, foram separadas em raiz, colmo + perfilho e folha, e aquelas 
coletadas no momento da formação de grãos foram separadas em raiz, colmo + perfilho, folha, raquis e grão.

- As diversas partes da planta foram lavadas em ägua destilada corrente e enxugadas em papel toalha. As raízes no solo, foram coletadas com ajuda de uma peneira (malha de $2 \mathrm{~mm}$ ), e logo após foram lavadas sucessivamente com água destilada e água desionizada. Depois, os materiais coletados foram acondicionados em sacos de papel devidamente identificados, e colocados para secar em estufa com circulação forçada de ar, à temperatura de $60^{\circ} \mathrm{C}$, no mínimo por 72 horas. Após a secagem, os materiais foram pesados, e logo triturados em moinho "Wiley" com peneira de malha 20, e acondicionados em saquinhos de papel para posteriores anālises.

\subsection{Anālises químicas}

- Plantas: as amostras secas foram digeridas em ácido nítrico e perclórico concentrados, segundo o método descrito por GANJE \& PAGE (1974). Em seguida, os extratos foram utilizados para a determinação dos teores de nutrientes e de nïquel, pelos seguintes métodos: Colorimetria da mistura molibdato-vanadato (P), fotometria de chama (K), absorção atômica ( $\mathrm{Ca}, \mathrm{Mg}, \mathrm{Cu}, \mathrm{Fe}, \mathrm{Mn}, \mathrm{Zn}$ e $\mathrm{Ni}$ ), e turbidimetria do sulfato de bärio (S). Também foram analisados, o teor de $\mathrm{N}$ na matéria seca (Microkjeldahl) e o teor de B no extrato clorídrico das cinzas (Colorimetria da curcumina), métodos descritos em MALAVOLTA (1979) e JORGENSEN (1977) . 
- Solos: o pH foi determinado potenciométricamente usan do relação solo: $\mathrm{CaCl}_{20} 0,01 \mathrm{M}$ de $1: 2,5$; a granulometria pelo método de BOUYOUCOS (1951); a matēria orgânica, por via umida (WALKLEY \& BLACK, 1934); P-disponivel, pela resina trocadora de ions (RAIJ \& QUAGGIO,

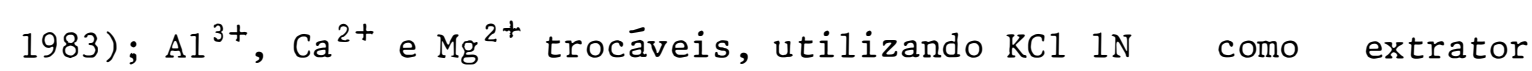
(VETTORI, 1969); e $\mathrm{K}^{+}$trocável utilizando o extrator Mehlich (VETTORI, 1969). O Ni-total foi extraỉdo por ataque perclörico-fluorídrico, conforme RAIJ \& VALADARES (1974), e determinado por espectrofotometria de absorção atômica. O Ni-solūvel em DTPA-TEA pH 7,3 foi obtido pela técni ca descrita por LINDSAY \& NORVELL (1978) e determinado por absorção atômica .

3.8. Delineamento experimental e anālise estatística

o delineamento experimental utilizado foi em blocos ao acaso com arranjo fatorial. Os resultados dos ensaios foram submetidos a análises de variância, e a significância minnima das médias determinada pelo teste de Tukey. Em alguns casos foi feita a anālise de regressão, estudos de correlação simples e ajuste de equação quadrática. 


\section{RESULTADOS}

\subsection{Ensaios em solução nutritiva}

4.1.1. Ensaio 1: Estabelecimento dos níveis de $\mathrm{Ni}$ a serem utili zados

Na Tabela 2, Figura 1 e Apêndice 1, estão ilustrados os efeitos das doses de $\mathrm{Ni}$ sobre a produção de matéria seca de partes da planta e do total, nas culturas de arroz e feijão, por ocasião do máximo perfilhamento e floração, respectivamente. Mediante a utilização do teste de Tukey a 5\%, constatou-se que a adição de doses crescentes de Ni na solução nutritiva reduzem significativamente a produção de matēria seca nas duas espécies. Este comportamento foi semelhante para todas as partes da planta, sendo que as anālises de regressão realizadas mostraram que a produção de matēria seca no arroz reduziu-se linearmente com a elevação dos níveis de $\mathrm{Ni}$ na solução nutritiva, enquanto que no feijão estas reduções ajustaram-se melhor a um modelo quadrätico. No feijão, observou-se que não existem diferenças significativas $(P \leq 0,05)$ entre 
Tabela 2. Produção de matéria seca nas culturas de arroz e feijão, em função dos nỉveis de nỉquel na solução nutritiva ${ }^{1}$

\begin{tabular}{|c|c|c|c|c|c|}
\hline Culturas & $\mathrm{Ni}$ & Raiz & $\begin{array}{l}\text { Caule + Ramo } \\
\text { Colmo + Perfilho }\end{array}$ & Folha & Total \\
\hline & ppm & $-\cdots-\cdots$ & - & vaso -..-- & $\cdots-\cdots$ \\
\hline \multirow[t]{6}{*}{ Feijão } & 0 & $.2,28 a$ & $5,20 a$ & $6,95 a$ & $14,43 a$ \\
\hline & 1 & $1,87 a$ & $5,25 a$ & $6,20 a b$ & $13,32 \mathrm{a}$ \\
\hline & 2 & $0,96 \mathrm{ab}$ & $2,06 \mathrm{~b}$ & $4,80 \mathrm{~b}$ & $7,81 \mathrm{~b}$ \\
\hline & 4 & $0,21 \mathrm{~b}$ & $0,32 b c$ & $0,47 \quad c$ & $1,00 \quad c$ \\
\hline & 8 & $0,08 \mathrm{~b}$ & $0,10 \quad c$ & $0,50 \quad c$ & $0,68 \quad c$ \\
\hline & 16 & $0,05 \mathrm{~b}$ & $0,10 \quad c$ & $0,36 \quad c$ & $0,50 \quad c$ \\
\hline \multirow[t]{6}{*}{ Arroz } & 0 & $7,06 a$ & $7,98 a$ & $7,03 a$ & $22,07 a b$ \\
\hline & 1 & $8,03 a$ & $8,53 a$ & $8,08 a$ & $24,64 a$ \\
\hline & 2 & $8,07 a$ & $7,68 \mathrm{ab}$ & $8,16 a$ & $23,92 \mathrm{ab}$ \\
\hline & 4 & $7,27 a$ & $5,96 \mathrm{~b}$ & $6,93 a$ & $20,16 \mathrm{~b}$ \\
\hline & 8 & $2,54 \mathrm{~b}$ & $2,42 \quad c$ & $3,90 \mathrm{~b}$ & 8,85 \\
\hline & 16 & $0,08 \quad c$ & $0,04 d$ & $0,08 \mathrm{c}$ & 0,20 \\
\hline DMS (Tukey & $5 \%)$ & 1,42 & 1,76 & 1,54 & 4,23 \\
\hline C.V. $\%$ & & 17,4 & 18,1 & 13,5 & 14,5 \\
\hline
\end{tabular}

1 Média de 3 repetições 


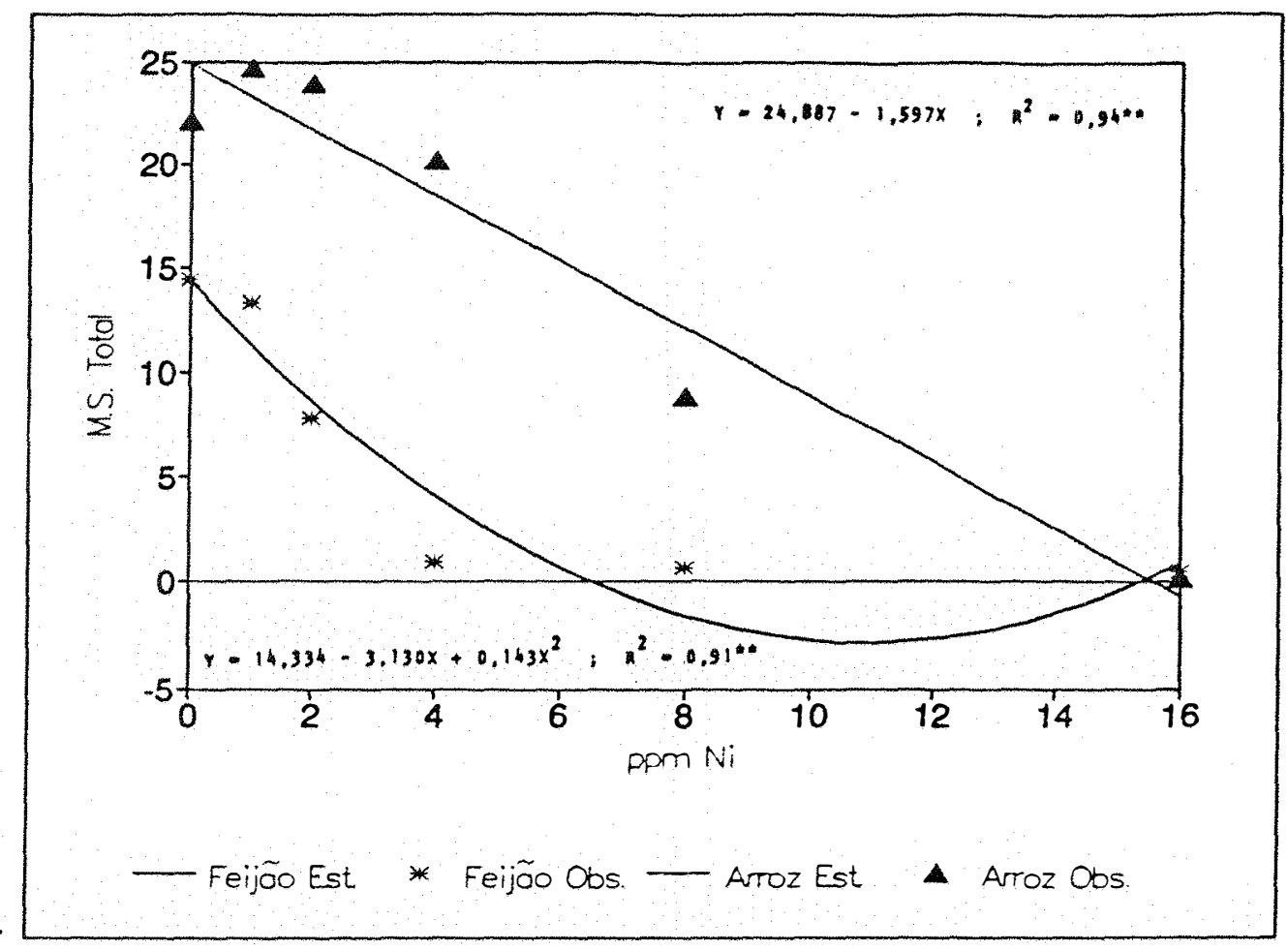

Figura 1. Relação entre a produção de matēria seca total (g/vaso) nas culturas de arroz e feijão, e níveis de níquel (ppm) na solução nutritiva

os nîveis de 4, 8 e 16ppm de $\mathrm{Ni}$ na solução nutritiva. Tratamentos estes que ocasionaram as mais baixas produções de matéria seca.

Os teores de nutrientes (Apêndice 2) apresentaram, em geral, uma tendência a aumentar na sua concentração por efeito das doses crescentes de $\mathrm{Ni}$ na solução em todas as partes da planta. Nas folhas de feijão, notou-se uma tendência a diminuir dos teores de $\mathrm{Ca}, \mathrm{Mg}$ e $\mathrm{Mn}$, enquanto que o teor de $\mathrm{Ni}$ aumentou com as doses crescentes de $\mathrm{Ni}$. Nas foLhas de arroz, verificou-se esta tendência de diminuição nos teores de $\mathrm{Ca}, \mathrm{Mg}, \mathrm{Fe}$ e Mn. As doses crescentes de $\mathrm{Ni}$ na solução nutritiva também 
afetaram os teores de $\mathrm{Ni}$ nas diversas partes da planta, nas duas culturas, aumentando o teor conforme aumentam as doses. Entre as partes de arroz e feijão, as raízes apresentaram teores de 2 a 5 vezes maiores em relação aos teores nas folhas.

As quantidades de nutrientes (Apêndice 3) foram afetadas pelas doses de $\mathrm{Ni}$ na solução nutritiva, nas duas espécies, diminuindo devido à influência da baixa produção de matēria seca. Por outro lado, as quantidades totais acumuladas de $\mathrm{Ni}$ aumentam com adições de $\mathrm{Ni}$. Verificou-se este comportamento, no arroz até o nivel de 8ppm de Ni na solução, e no feijão até $4 \mathrm{ppm}$ de $\mathrm{Ni}$. Observou-se nas quantidades totais de nutrientes, um efeito negativo conforme aumentam os niveis de $\mathrm{Ni}$ na solução nutritiva. No arroz, estes efeitos negativos apresentaram-se nos tratamentos com altas doses de $\mathrm{Ni}$ (4, 8 e 16ppm).

Este primeiro ensaio serviu para estabelecer os niveis de concentração de $\mathrm{Ni}$ a serem utilizados na solução nutritiva para avaliar os efeitos da toxidez de $\mathrm{Ni}$ em arroz e feijão, sendo que foram estabelecidas concentrações de até 4ppm para feijão, e de até 12ppm para arroz.

4.1.2. Ensaio 2. Avaliação dos efeitos da toxidez de Ni em feijão

A produção de matéria seca no feijão cultivar Carioca (Tabela 3, Figura 2 e Apêndice 4) das partes e do total, por ocasião da floração, apresentaram reduções significativas $(P \leq 0,05)$ em função dos niveis de $\mathrm{Ni}$ na solução nutritiva. Nota-se que $1 \mathrm{ppm}$ de $\mathrm{Ni}$ na solução nutritiva não afeta significativamente a produção de matéria seca, em 
relação à testemunha, sem Ni. Tambēm houve correlações significativas $(\mathrm{P}<0,01)$ entre a produção de matēria seca e níveis de $\mathrm{Ni}$ na solução nutritiva; as anālises realizadas mostram reduções lineares para todas as partes da planta com exceção das folhas que apresentam um efeito quadrätico.

Tabela 3. Produção de matéria seca e teor de clorofila total em feijão cultivar Carioca, em função dos nỉveis de níquel na solução nutritiva 1

\begin{tabular}{|c|c|c|c|c|c|}
\hline $\mathrm{Ni}$ & Raiz & $\begin{array}{l}\text { Caule + } \\
\text { Ramo }\end{array}$ & Folha & Total & Clorofila \\
\hline ppm & \multicolumn{4}{|c|}{ - g/vaso - - } & $\mu g / g$ m.f. \\
\hline 0 & $2,28 a$ & $5,20 a$ & $6,95 a$ & $14,43 a$ & $1745 a$ \\
\hline 1 & $1,87 a$ & $5,25 a$ & $6,20 a$ & $13,32 \mathrm{a}$ & $1462 a$ \\
\hline 2 & $0,96 \mathrm{~b}$ & $2,06 \mathrm{~b}$ & $4,80 \mathrm{~b}$ & $7,81 \mathrm{~b}$ & $1456 a$ \\
\hline 4 & $0,21 \mathrm{c}$ & $0,32 \mathrm{~b}$ & $0,47 \quad c$ & $1,00 \quad c$ & $836 \mathrm{~b}$ \\
\hline DMS (Tukey 5\%) & 0,71 & 2,01 & 1,17 & 3,56 & 369 \\
\hline C.V. \% & 18,8 & 22,2 & 9,0 & 13,7 & 9,5 \\
\hline
\end{tabular}

1 Mëdia de 3 repetições 


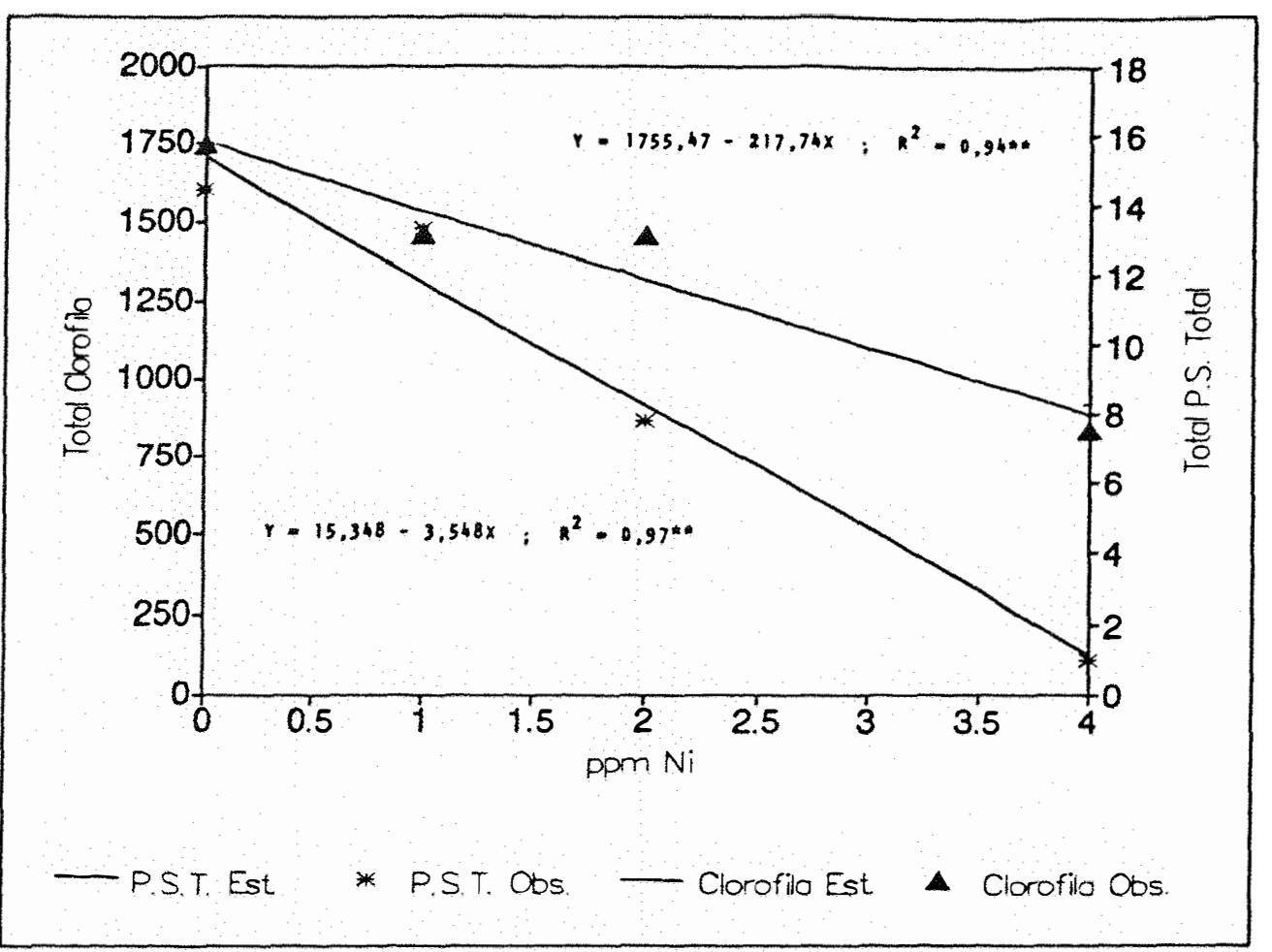

Figura 2. Relação entre a produção de matéria seca total (g/vaso) e o teor de clorofila total nas folhas ( $\mu \mathrm{g} / \mathrm{g}$ de matéria fresca) de feijão, e níveis de níquel (ppm) na solução nutritiva

Anālises do teor de clorofila total em folhas de feijão (Tabela 3, Figura 2 e Apêndice 4) mostraram que não existe um efeito significativo $(\mathrm{P} \leq 0,05)$ dos nỉveis de $\mathrm{Ni}$ na solução nutritiva ate $2 \mathrm{ppm}$. Niveis de $4 \mathrm{ppm}$ de $\mathrm{Ni}$ na solução nutritiva reduzem em $52 \%$ o teor de clorofila total, em relação à testemunha. Porēm, estes resultados ajustaram-se melhor a uma função linear e negativa $(P \leq 0,01)$. 
As equações de regressão para as quantidades de nutrientes na planta toda e nas folhas de feijão (Figura 3 e Apêndice 5), em função dos níveis de $\mathrm{Ni}$ na solução nutritiva mostraram um efeito negativo significativo $(P \leq 0,05)$ na acumulação de nutrientes na planta ( $\mathrm{Mg}, \mathrm{Cu}$ e Mn) e nas folhas ( $S$, Cu e Mn). Entre os macronutrientes, verificou-se uma forte queda na quantidade total de Mg na planta de feijão, enquanto que, entre os micronutrientes, a queda nas quantidades totais de $\mathrm{Cu}$ e Mn foi semelhante. Os outros nutrientes, também foram afetados negativamente por doses crescentes de $\mathrm{Ni}$, entretanto, os dados não se ajustaram a nenhuma função matemática.

4.1.3. Ensaio 3. Avaliação dos efeitos da toxidez de Ni em dois cultivares de feijão

Os resultados da produção de matéria seca em dois cultivares de feijão (Carioca e IAPAR-14), por ocasião da floração e formação de grãos, são apresentados na Tabela 4, Figura 4 e Apêndice 6 . Constatou-se pelo teste de Tukey $(P \leq 0,05)$, mudanças significativas da interação cultivares $\mathrm{x}$ nỉveis de $\mathrm{Ni}$, em função dos nivveis de $\mathrm{Ni}$ na solução nutritiva. A produção foi semelhante nos dois cultivares, entretanto, as doses de $\mathrm{Ni}$ afetaram em maior grau ao cultivar Carioca, sendo que este comportamento indica uma maior tolerânica do cultivar IAPAR-14 à toxidez de Ni. Por ocasião da floração, verificou-se uma redução na produção de matéria seca total de 84 e $92 \%$ para os cultivares IAPAR-14 e Carioca, respectivamente, quando submetidos a $4 \mathrm{ppm}$ de $\mathrm{Ni}$, em relação à testemunha. Na segunda coleta, estādio de formação de grãos, as reduções foram de 70 e 95\% para os cultivares IAPAR-14 e Carioca, respectivamente. 

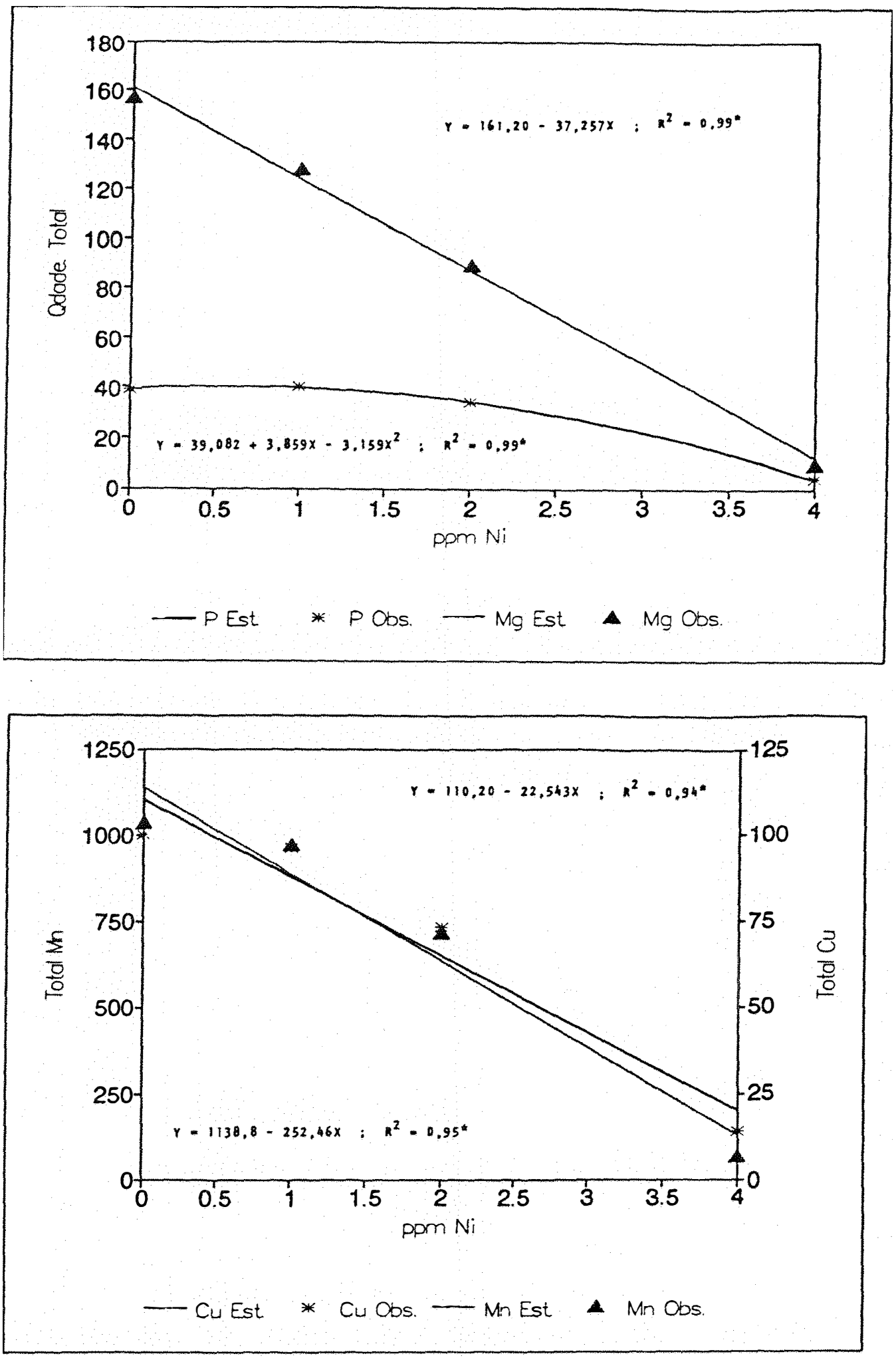

Figura 3. Relação entre as quantidades totais de $\mathrm{P}$ e $\mathrm{Mg}$ (mg/vaso), Cu e Mn ( $\mu g / v a s o$ ) no feijoeiro, e nỉveis de níquel (ppm) na solução nutritiva 


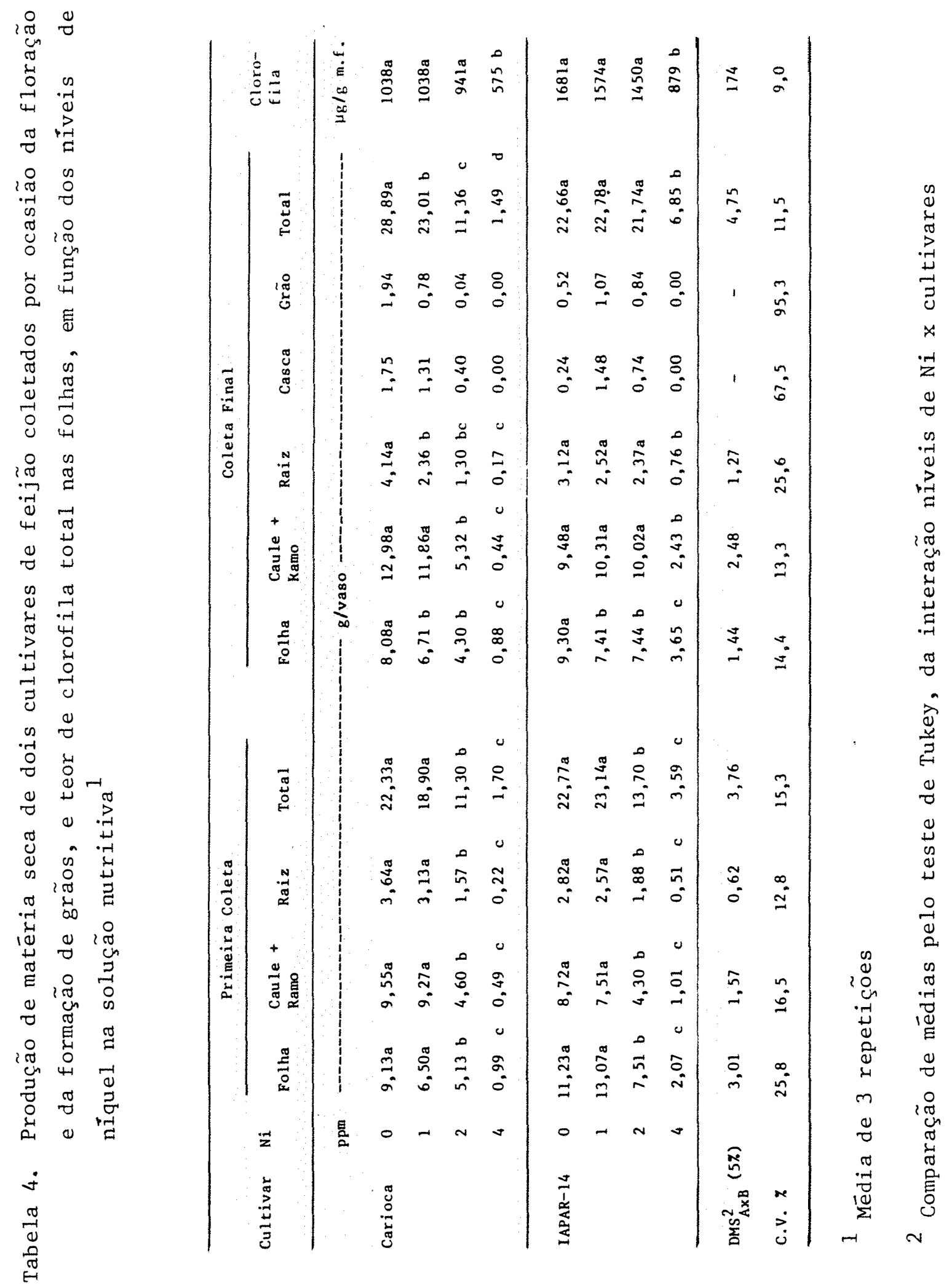



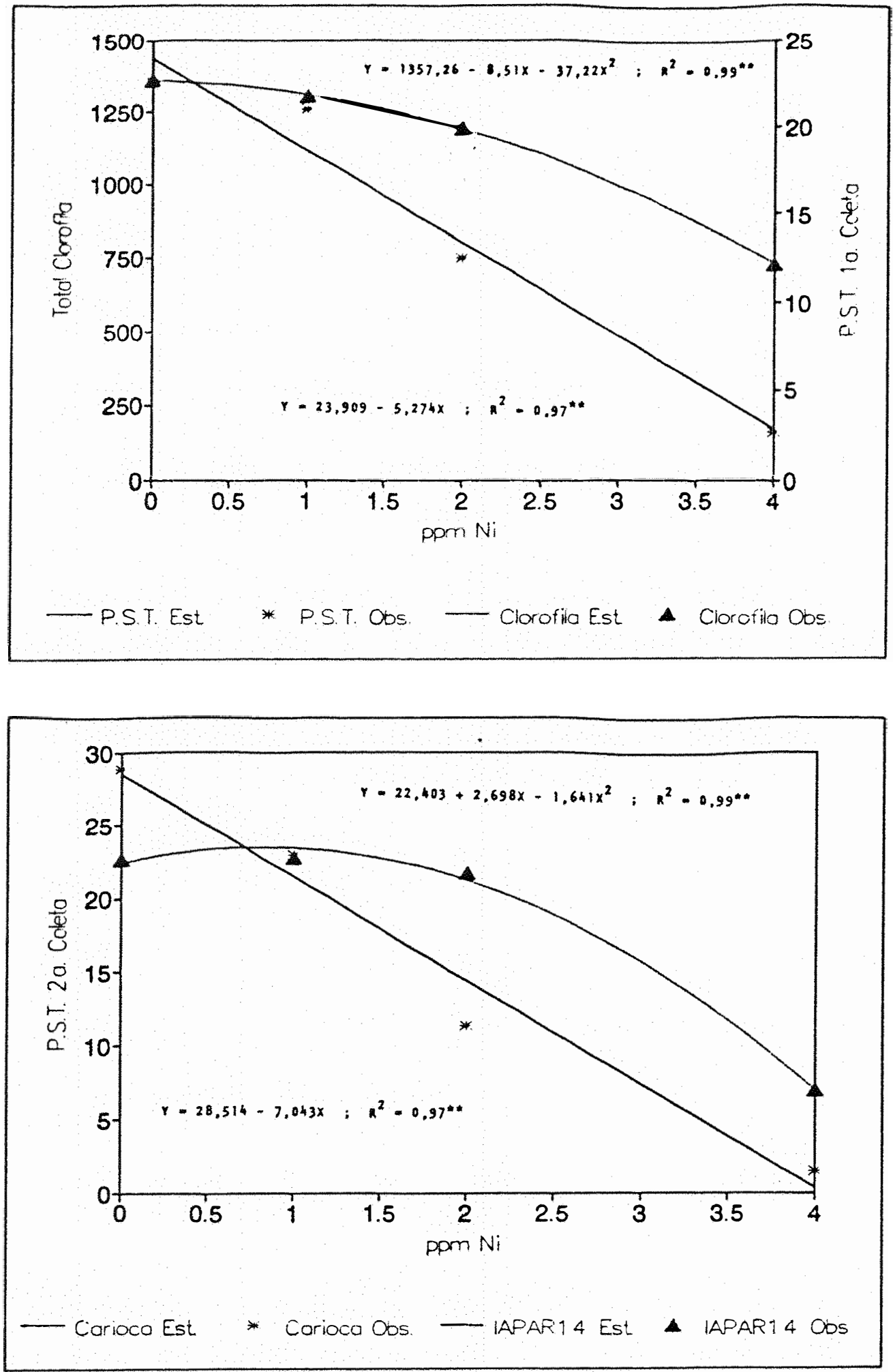

Figura 4. Relação entre a produção de matéria seca total da primeira coleta (g/vaso), teor de clorofila total nas folhas ( $\mu \mathrm{g} / \mathrm{g}$ de matéria fresca) e produçãc de matéria seca total da segunda coleta nos dois cultivares de feijão (Carioca e IAPAR-14), e níveis de níquel (ppm) na solução nutritiva 
Tambëm, na segunda coleta, verificou-se que o cultivar IAPAR-14 não apre senta diferenças significativas $(P \leq 0,05)$ entre os niveis de 0,1 e 2ppm de Ni na solução nutritiva.

As anālises de regressão, demonstraram correlações negativas significativas $(\mathrm{P} \leq 0,01)$ para 0 peso seco total nas duas coletas, em relação às doses de $\mathrm{Ni}$. Na primeira coleta (floração) o efeito foi linear, enquanto que na segunda coleta (formação de grãos) comprovou-se um efeito negativo linear para o cultivar Carioca e quadrático para o cultivar IAPAR-14.

0 teor de clorofila total nas folhas (Tabela 4 e Figura 4), em relação às doses de $\mathrm{Ni}$, diminui quadrāticamente $(\mathrm{P} \leq 0,01)$. Pelo teste de Tukey a 5\%, verificou-se que não existem diferenças significativas entre os níveis de 0,1 e $2 \mathrm{ppm}$ de $\mathrm{Ni}$ no teor de clorofila total. 0 nỉvel de $4 \mathrm{ppm}$ de $\mathrm{Ni}$ reduz significativamente o teor de clorofila total nas folhas de feijão.

Os teores de nutrientes e níquel (Tabela 5, Figura 5 e Apêndices 7, 8 e 9) apresentam correlações significativas $(P \leq 0,01)$ para algumas variāveis. Por ocasião da floração, aumentam linearmente os teores de Mn nas folhas do cultivar Carioca, e de Ni nos dois cultivares, em relação às doses de Ni. Entretanto, observou-se diminuições no teor de Mg da raiz do cultivar Carioca por ação dos níveis de Ni. Por ocasião da formação de grãos, verificou-se uma redução linear $(P \leq 0,01)$ do teor de Mg no caule + ramo do cultivar IAPAR-14, devido aos níveis crescentes de Ni. Em geral, encontraram-se efeitos quadráticos altamente significativos $(P \leq 0,01)$ no teor de nutrientes nas folhas por ocasião 
Tabela 5. Equações de regressão entre teores de nutrientes e níquel (\% e ppm) em dois cultivares de feijoeiro (Y), e ppm de $\mathrm{Ni}$ (X) na solução nutritiva

\begin{tabular}{|c|c|c|c|c|c|c|}
\hline & Variävel & & & Equação de Regressão & $\mathrm{R}^{2}$ & $F$ \\
\hline Coleta & Parte & Nutriente & Cultivar & & & \\
\hline \multirow[t]{10}{*}{1} & \multirow[t]{2}{*}{ Folha } & $M n$ & $\begin{array}{l}\text { Carioca } \\
\text { IAPAR-14 }\end{array}$ & $\begin{array}{l}Y=53,00+9,571 X \\
Y=64,70+1,743 X\end{array}$ & $\begin{array}{l}0,99 \\
0,22\end{array}$ & ॥夫 \\
\hline & & $\mathrm{Ni}$ & $\begin{array}{l}\text { Carioca } \\
\text { IAPAR }-14\end{array}$ & $\begin{array}{l}Y=-22,80+86,743 X \\
Y=-21,30+75,600 X\end{array}$ & $\begin{array}{l}0,97 \\
0,95\end{array}$ & 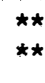 \\
\hline & \multirow[t]{3}{*}{$\begin{array}{l}\text { Caule + } \\
\text { Ramo }\end{array}$} & $P$ & $\begin{array}{l}\text { Carioca } \\
\text { IAPAR-14 }\end{array}$ & $\begin{array}{l}Y=0,219+0,038 X \\
Y=0,261+0,016 X\end{array}$ & $\begin{array}{l}0,99 \\
0,84\end{array}$ & 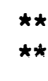 \\
\hline & & Mg & $\begin{array}{l}\text { Carioca } \\
\text { IAPAR }-14\end{array}$ & $\begin{array}{l}Y=0,509+0,072 X \\
Y=0,582+0,148 X-0,041 X^{2}\end{array}$ & $\begin{array}{l}0,95 \\
0,99\end{array}$ & 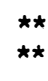 \\
\hline & & $\mathrm{Ni}$ & $\begin{array}{l}\text { Carioca } \\
\text { IAPAR-14 }\end{array}$ & $\begin{array}{l}Y=-43,70+129,614 x \\
Y=-1,90+54,729 x\end{array}$ & $\begin{array}{l}0,93 \\
0,98\end{array}$ & *夫 \\
\hline & \multirow[t]{5}{*}{ Raiz } & $\mathrm{Mg}$ & $\begin{array}{l}\text { Carioca } \\
\text { IAPAR-14 }\end{array}$ & $\begin{array}{l}Y=1,208-0,076 \mathrm{X} \\
\mathrm{Y}=1,182+0,291 \mathrm{X}-0,099 \mathrm{X}^{2}\end{array}$ & $\begin{array}{l}0,99 \\
0,93\end{array}$ & $\begin{array}{l}\star \star \\
\star \star\end{array}$ \\
\hline & & $\mathrm{Cu}$ & $\begin{array}{l}\text { Carioca } \\
\text { IAPAR }-14\end{array}$ & $\begin{array}{l}Y=8,545-7,773 X+5,773 X^{2} \\
Y=9,832-5,766 X+3,716 x^{2}\end{array}$ & $\begin{array}{l}0,99 \\
0,99\end{array}$ & 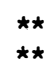 \\
\hline & & $\mathrm{Fe}$ & $\begin{array}{l}\text { Carioca } \\
\text { IAPAR }-14\end{array}$ & $\begin{array}{l}Y=667,395-594,098 X+665,648 X^{2} \\
Y=998,041-667,82 X+548,67 X^{2}\end{array}$ & $\begin{array}{l}0,99 \\
0,99\end{array}$ & $\begin{array}{l}\star \star \\
\star \star\end{array}$ \\
\hline & & $M n$ & $\begin{array}{l}\text { Carioca } \\
\text { IAPAR }-14\end{array}$ & $\begin{array}{l}Y=47,718-33,709 X+36,909 X^{2} \\
Y=49,50+13,00 X\end{array}$ & $\begin{array}{l}0,99 \\
0,87\end{array}$ & 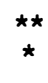 \\
\hline & & $\mathrm{zn}$ & $\begin{array}{l}\text { Carioca } \\
\text { IAPAR-14 }\end{array}$ & $\begin{array}{l}Y=34,323-25,861 X+16,511 X^{2} \\
Y=42,973-20,536 X+9,636 X^{2}\end{array}$ & $\begin{array}{l}0,99 \\
0,98\end{array}$ & $\begin{array}{l}\star \star \\
\star \star\end{array}$ \\
\hline \multirow[t]{15}{*}{2} & \multirow[t]{7}{*}{$\begin{array}{l}\text { Caule + } \\
\text { Ramo }\end{array}$} & $\mathrm{N}$ & $\begin{array}{l}\text { Carioca } \\
\text { IAPAR }-14\end{array}$ & $\begin{array}{l}\mathrm{Y}=1,68+1,120 \mathrm{X}-0,165 \mathrm{X}^{2} \\
\mathrm{Y}=2,11-0,510 \mathrm{X}+0,220 \mathrm{X}^{2}\end{array}$ & $\begin{array}{l}0,97 \\
0,99\end{array}$ & * \\
\hline & & $P$ & $\begin{array}{l}\text { Carioca } \\
\text { IAPAR }-14\end{array}$ & $\begin{array}{l}Y=0,208+0,043 X \\
Y=0,295-0,034 X+0,011 X^{2}\end{array}$ & $\begin{array}{l}0,97 \\
0,99\end{array}$ & $\begin{array}{ll}* \star \\
\star \star\end{array}$ \\
\hline & & $\mathrm{k}$ & $\begin{array}{l}\text { Carioca } \\
\text { LAPAR }-14\end{array}$ & $\begin{array}{l}Y=2,069-0,154 X+0,219 X^{2} \\
Y=2,99-0,755 X+0,275 x^{2}\end{array}$ & $\begin{array}{l}0,99 \\
0,96\end{array}$ & $\begin{array}{l}\star \star \star \\
\star \star\end{array}$ \\
\hline & & $\mathrm{Mg}$ & $\begin{array}{l}\text { Carioca } \\
\text { IAPAR-14 }\end{array}$ & $\begin{array}{l}Y=0,528+0,025 X \\
Y=0,594-0,044 X\end{array}$ & $\begin{array}{l}0,87 \\
0,82\end{array}$ & $\begin{array}{l}\star \star \\
\star \star\end{array}$ \\
\hline & & $\mathrm{Fe}$ & $\begin{array}{l}\text { Carioca } \\
\text { IAPAR-14 }\end{array}$ & $\begin{array}{l}Y=132,34-35,218 X+9,818 X^{2} \\
Y=144,95+99,225 X-25,375 X^{2}\end{array}$ & $\begin{array}{l}0,92 \\
0,62\end{array}$ & $\star \star$ \\
\hline & & $\mathrm{Mn}$ & $\begin{array}{l}\text { Carioca } \\
\text { IAPAR }-14\end{array}$ & $\begin{array}{l}Y=22,62-6,01 X+1,41 X^{2} \\
Y=14,56+20,87 X-3,92 X^{2}\end{array}$ & $\begin{array}{l}0,62 \\
0,99\end{array}$ & $\stackrel{n}{\text { ns }}$ * \\
\hline & & $\mathrm{Ni}$ & $\begin{array}{l}\text { Carioca } \\
\text { IAPAR }-14\end{array}$ & $\begin{array}{l}Y=8,823+10,64 X+31,51 X^{2} \\
Y=-7,60+72,414 X\end{array}$ & $\begin{array}{l}0,99 \\
0,99\end{array}$ & 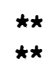 \\
\hline & \multirow[t]{8}{*}{ Raiz } & $\mathrm{N}$ & $\begin{array}{l}\text { Carioca } \\
\text { IAPAR }-14\end{array}$ & $\begin{array}{l}Y=2,58+0,261 X \\
Y=3,04-0,357 X+0,127 X^{2}\end{array}$ & $\begin{array}{l}0,82 \\
0,64\end{array}$ & $\stackrel{\star \star}{\star}$ \\
\hline & & $\mathrm{k}$ & $\begin{array}{l}\text { Carioca } \\
\text { IAPAR-14 }\end{array}$ & $\begin{array}{l}Y=2,86+0,651 X-0,161 X^{2} \\
Y=1,30+0,879 X\end{array}$ & $\begin{array}{l}0,31 \\
0,85\end{array}$ & ns \\
\hline & & $\mathrm{Ca}$ & $\begin{array}{l}\text { Carioca } \\
\text { IAPAR }-14\end{array}$ & $\begin{array}{l}Y=0,533-0,117 X+0,074 X^{2} \\
Y=0,763-0,128 X+0,029 X^{2}\end{array}$ & $\begin{array}{l}0,99 \\
0,95\end{array}$ & $\begin{array}{l}\star \star \\
\text { ns }\end{array}$ \\
\hline & & $\mathrm{Mg}$ & $\begin{array}{l}\text { Carioca } \\
\text { IAPAR }-14\end{array}$ & $\begin{array}{l}Y=0,604-0,154 X+0,039 X^{2} \\
Y=0,383+0,180 X-0,041 X^{2}\end{array}$ & $\begin{array}{l}0,86 \\
0,71\end{array}$ & $\stackrel{*}{\star}$ \\
\hline & & $\mathrm{Cu}$ & $\begin{array}{l}\text { Carioca } \\
\text { IAPAR }-14\end{array}$ & $\begin{array}{l}Y=7,05-5,725 X+5,875 X^{2} \\
Y=8,10+4,30 X\end{array}$ & $\begin{array}{l}0,99 \\
0,77\end{array}$ & 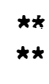 \\
\hline & & $\mathrm{Fe}$ & $\begin{array}{l}\text { Carioca } \\
\text { IAPAR }-14\end{array}$ & $\begin{array}{l}Y=716,95+50,93 X+484,27 X^{2} \\
Y=508,0+812,714 X\end{array}$ & $\begin{array}{l}1,00 \\
0,81\end{array}$ & * \\
\hline & & $\mathrm{Mn}$ & $\begin{array}{l}\text { Carioca } \\
\text { IAPAR-14 }\end{array}$ & $\begin{array}{l}Y=98,186-50,54 X+36,19 X^{2} \\
Y=163,68-178,14 X+62,49 X^{2}\end{array}$ & $\begin{array}{l}0,99 \\
0,99\end{array}$ & ** \\
\hline & & $\mathrm{zn}$ & $\begin{array}{l}\text { Carioca } \\
\text { IAPAR-14 }\end{array}$ & $\begin{array}{l}Y=43,51-23,655 X+15,955 X^{2} \\
Y=35,30-17,60 X+8,50 X^{2}\end{array}$ & $\begin{array}{l}0,99 \\
0,99\end{array}$ & 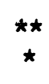 \\
\hline
\end{tabular}

** Significativo ao nível de $1 \%$

* Significativo ao nivel de $5 \%$

ns Não significativo 

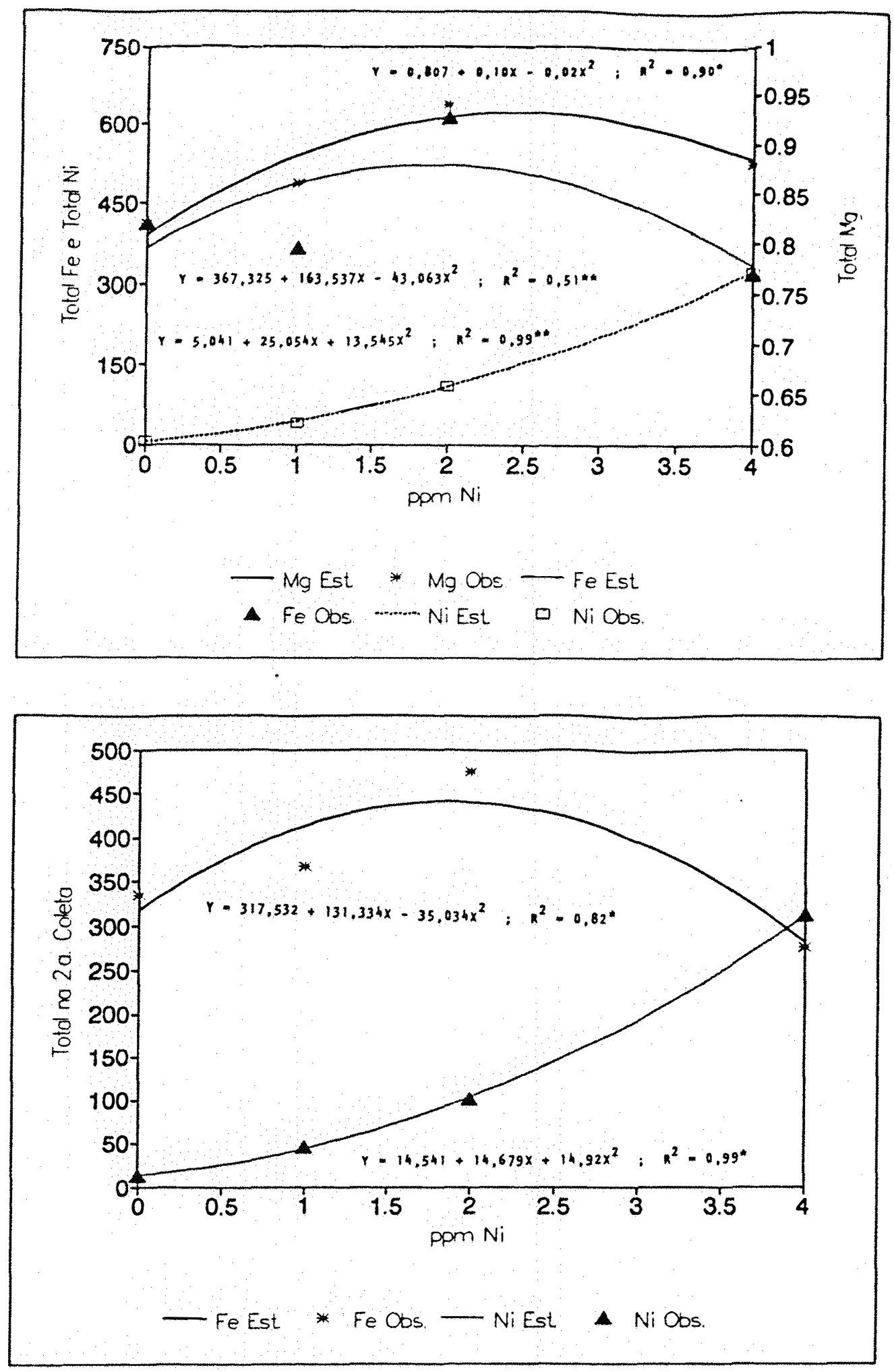

Figura 5. Relação entre os teores de nutrientes e níquel (\% e ppm) nas folhas de feijão para as duas coletas (floração e formação de grãos), e nỉveis de níquel (ppm) na solução nutritiva 
da floração ( $M g$ e Fe) e da formação de grãos (Fe). Estes efeitos confir mam a existência de certo grau de interação do $\mathrm{Ni}$ com o Fe e o $\mathrm{Mg}$, nas duas coletas realizadas.

0 teor de $\mathrm{Ni}$ nas folhas, nas duas coletas, aumentou em função aos nỉveis crescentes de $\mathrm{Ni}$ na solução nutritiva. Também observou-se que o teor de $\mathrm{Ni}$ nas partes da planta (Apêndice 9), aumenta por ação dos nỉveis de Ni na solução, nas duas coletas. Por outro lado, verificou-se que a maior acumulação de Ni está nas raízes, sendo que o cultivar IAPAR-14 concentra mais do que o cultivar Carioca, quando as plantas foram submetidas a soluções nutritivas com $4 \mathrm{ppm}$ de Ni. Nas equações de regressão $(P \leq 0,01)$, encontrou-se correlações positivas entre teores de $\mathrm{Ni}$ na matēria seca do feijoeiro e doses crescentes de $\mathrm{Ni}$ na solução nutritiva.

4.1.4. Ensaio 4. Avaliação dos efeitos da toxidez de $\mathrm{Ni}$ em duas variedades de arroz

Na Tabela 6, Figura 6 e Apêndice 10, estão ilustrados os efeitos dos niveis de Ni sobre a produção de matéria seca de duas variedades de arroz (IAC-165 e IAC-4440), coletadas por ocasião do perfilhamento e formação de grãos. Verificou-se, pelo teste de Tukey $(P \leq 0,05)$ da interação variedades $x$ niveis de $\mathrm{Ni}$, efeitos altamente significativos. As duas variedades apresentaram comportamento semelhante nas duas épocas de coleta. Também observou-se que, praticamente não existem diferenças significativas na produção de matéria seca entre os tratamentos com 0 e $4 \mathrm{ppm}$ de $\mathrm{Ni}$, sendo que no arroz, as reduções na produção de matéria seca ocorre com niveis acima de $4 \mathrm{ppm}$ de $\mathrm{Ni}$ ( 8 e $12 \mathrm{ppm}$ de $\mathrm{Ni}$ ). 


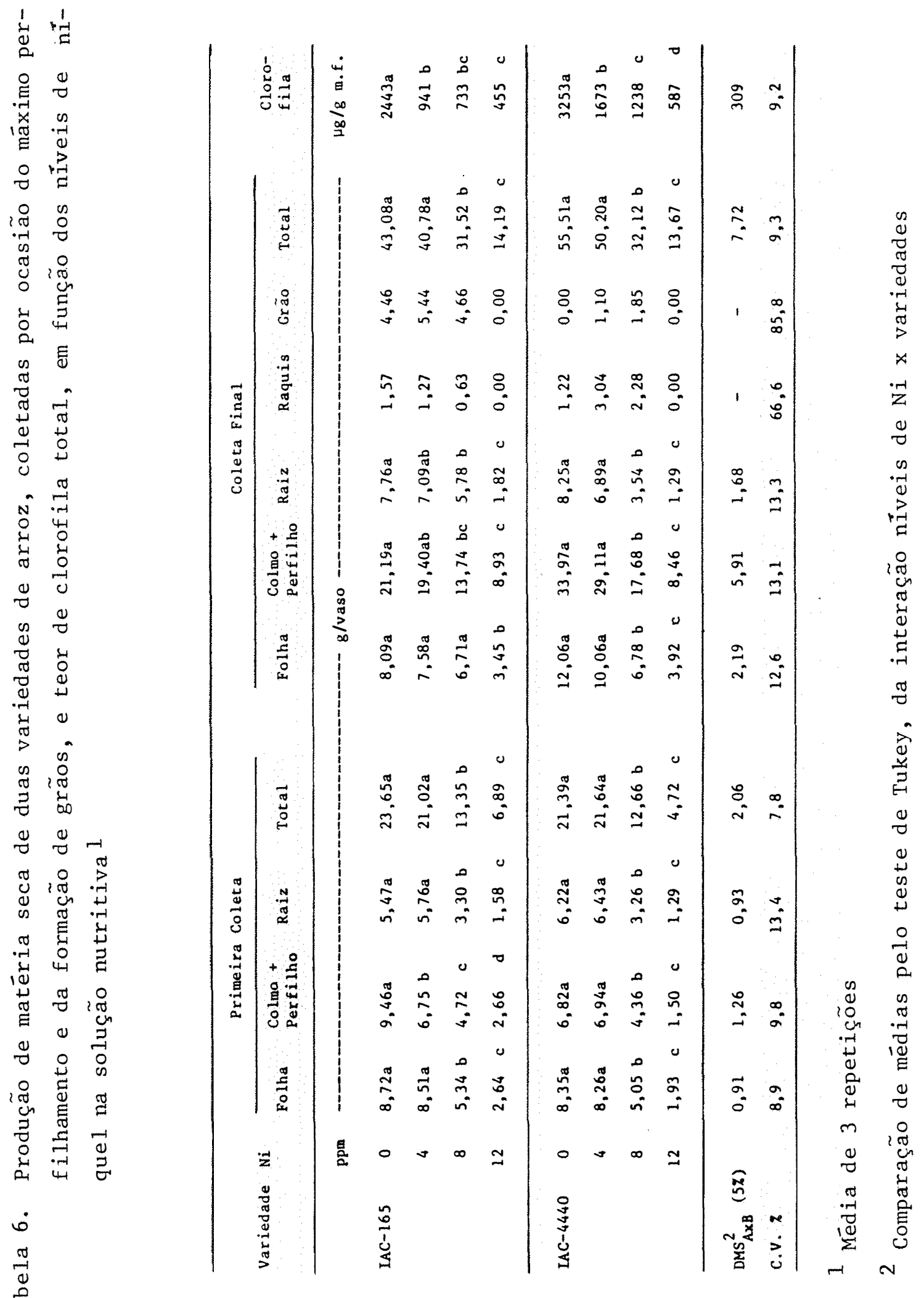



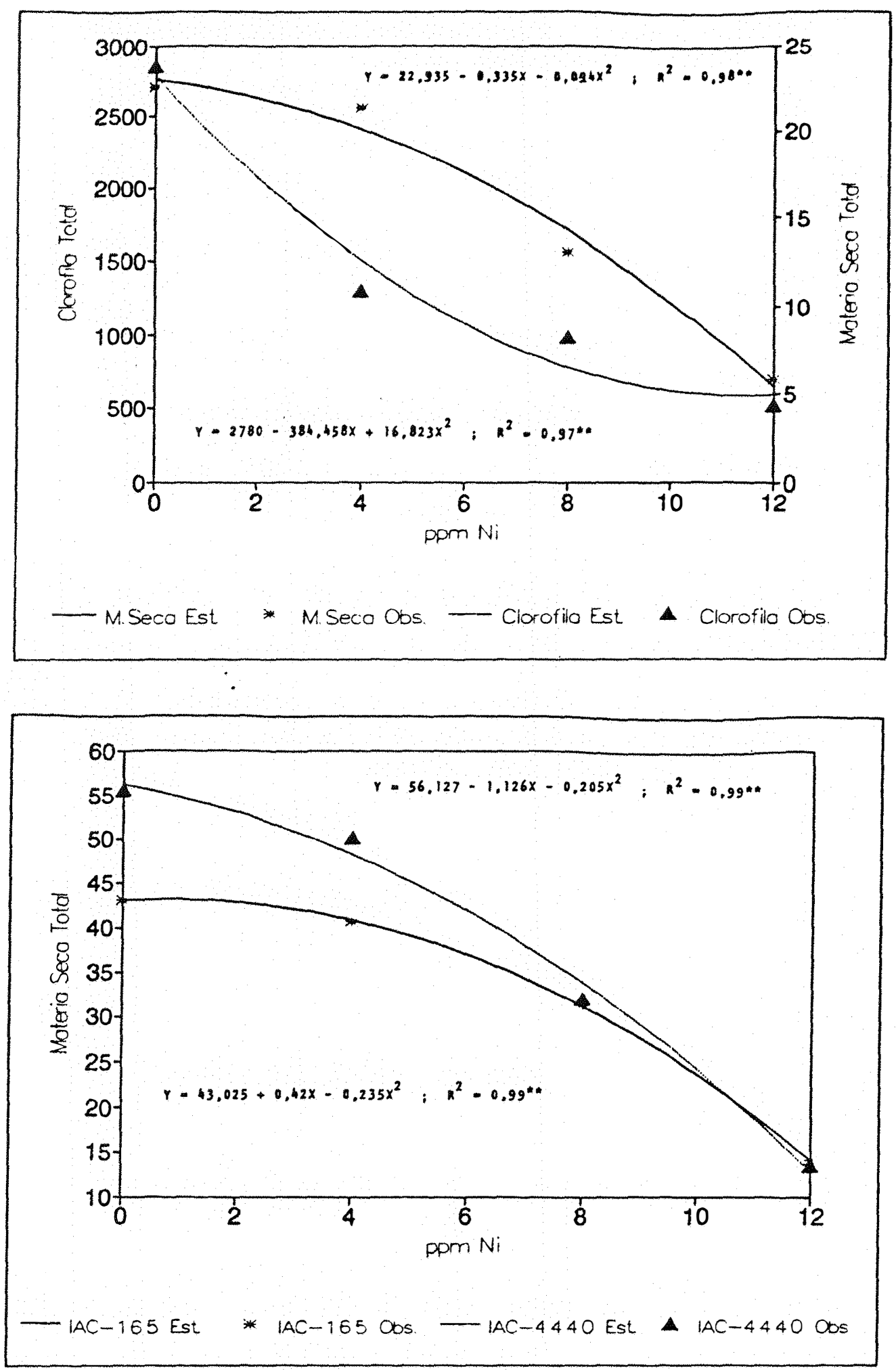

Figura 6. Relação entre a produção de matéria seca total da primeira coleta (g/vaso), teor de clorofila total ( $\mu \mathrm{g} / \mathrm{g}$ de matéria fresca) e produção de matéria seca total da segunda coleta nas duas variedades de arroz (IAC-165 e IAC-4440), e níveis de níquel (ppm) na solução nutritiva 
As equações de regressão (Apêndice 10) para produção de ma téria seca em função dos níveis de $\mathrm{Ni}$ na solução nutritiva, apresentaram correlações significativas $(P \leq 0,01)$ para o peso seco total nas duas co letas. Por ocasião do perfilhamento e na época de formação de grãos, os efeitos das doses de $\mathrm{Ni}$ sobre a produção de matéria seca foram quadráticos. Entretanto, na segunda coleta (formação de grãos), existem ligeiras diferenças entre as equações de regressão que indicam uma maior tolerância à toxidez de $\mathrm{Ni}$ da variedade IAC-165 ( $\left.\mathrm{Y}=43,025+0,42 \mathrm{X}-0,235 \mathrm{X}^{2}\right)$, em relação à variedade $\operatorname{IAC}-4440\left(Y=56,127-1,126 \mathrm{X}-0,205 \mathrm{X}^{2}\right)$. A variedade IAC-4440 apresenta uma maior capacidade de produção de matéria seca do que a variedade IAC-165, na época de formação de grãos, sendo que nas doses de 4 e $8 \mathrm{ppm}$ de $\mathrm{Ni}$ sua produção ainda foi superior, em comparação com a variedade IAC-165.

As doses de Ni, tambēm afetaram significativamente o teor de clorofila total nas folhas de arroz (Tabela 6, Figura 6 e Apêndice 10). Verificou-se pelo teste de Tukey a $5 \%$, que existem reduções significativas conforme aumentam os niveis de $\mathrm{Ni}$ na solução nutritiva. Esta redução pode atingir $81 \%$ no tratamento com $12 \mathrm{ppm}$ de $\mathrm{Ni}$, em relação à testemunha, sem Ni. As equações de regressão ajustaram-se a uma função quadrática. As correlações entre o teor de clorofila total nas folhas e o teor de Ni nas folhas não foram significativas.

Os teores de nutrientes e níquel na matéria seca de arroz, em geral, aumentaram com as doses de $\mathrm{Ni}$ na solução nutritiva (Tabela 7 , Figura 7 e Apêndices 11, 12 e 13). Na primeira coleta (perfilhamento), observou-se reduções no teor de Mg da folha para ambas as variedades, 
Tabela 7. Equações de regressão entre teores de nutrientes e níquel (\% e ppm) em duas variedades de arroz (Y), e ppm de $\mathrm{Ni}$ (X) na solução nutritiva

\begin{tabular}{|c|c|c|c|c|c|c|}
\hline \multicolumn{3}{|c|}{ Variävel } & \multicolumn{2}{|r|}{ Equaçāo de Regressão } & \multirow[t]{2}{*}{$R^{2}$} & \multirow[t]{2}{*}{$F$} \\
\hline Coleta & Parte & Nutriente & Variedade & & & \\
\hline \multirow[t]{8}{*}{1} & Folha & $P$ & $\begin{array}{l}\text { IAC }-165 \\
\text { IAC }-4440\end{array}$ & $\begin{array}{l}Y=0,274+0,009 x \\
Y=0,225-0,004 X+0,001 X^{2}\end{array}$ & $\begin{array}{l}0,87 \\
1,00\end{array}$ & $\begin{array}{l}\star \star \\
\star \star\end{array}$ \\
\hline & & $\mathrm{k}$ & $\begin{array}{l}\text { IAC }-165 \\
\text { IAC }-4440\end{array}$ & $\begin{array}{l}Y=3,207+0,296 X-0,013 X^{2} \\
Y=4,332-0,061 X+0,01 X^{2}\end{array}$ & $\begin{array}{l}0,99 \\
0,99\end{array}$ & * \\
\hline & & Mg & $\begin{array}{l}\text { IAC }-165 \\
\text { IAC }-4440\end{array}$ & $\begin{array}{l}Y=0,787-0,022 X \\
Y=0,809-0,0415 X\end{array}$ & $\begin{array}{l}0,79 \\
0,83\end{array}$ & $\begin{array}{l}* * \\
* *\end{array}$ \\
\hline & & $\mathrm{Fe}$ & $\begin{array}{l}\text { IAC }-165 \\
\text { IAC }-4440\end{array}$ & $\begin{array}{l}Y=160,925-7,894 X+1,023 X^{2} \\
Y=146,825-27,04 X+4,43 X^{2}\end{array}$ & $\begin{array}{l}0,95 \\
0,96\end{array}$ & $\stackrel{*}{*}$ \\
\hline & & $\mathrm{Ni}$ & $\begin{array}{l}\text { IAC }-165 \\
\text { IAC }-4440\end{array}$ & $\begin{array}{l}Y=40,75+43,187 X \\
Y=2,40+36,35 X\end{array}$ & $\begin{array}{l}0,97 \\
0,99\end{array}$ & ** \\
\hline & $\begin{array}{l}\text { Colmo }+ \\
\text { Perfilho }\end{array}$ & $\mathrm{Ca}$ & $\begin{array}{l}\text { IAC- } 165 \\
\text { IAC }-4440\end{array}$ & $\begin{array}{l}Y=0,562+0,0086 X-0,0007 X^{2} \\
Y=0,667+0,039 X-0,005 X^{2}\end{array}$ & $\begin{array}{l}0,16 \\
0,78\end{array}$ & $\underset{\star n s}{\star * \star}$ \\
\hline & . & $\mathrm{Mg}$ & $\begin{array}{l}\text { IAC }-165 \\
\text { IAC }-4440\end{array}$ & $\begin{array}{l}Y=0,428-0,014 X \\
Y=0,557-0,056 X+0,005 X^{2}\end{array}$ & $\begin{array}{l}0,93 \\
0,96\end{array}$ & $\stackrel{\star}{*} *$ \\
\hline & Raiz & $\mathrm{Cu}$ & $\begin{array}{l}\text { IAC }-165 \\
\text { IAC }-4440\end{array}$ & $\begin{array}{l}Y=4,375-0,594 X+0,148 X^{2} \\
Y=5,575-1,794 X+0,305 x^{2}\end{array}$ & $\begin{array}{l}0,98 \\
0,98\end{array}$ & 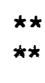 \\
\hline \multirow[t]{10}{*}{2} & Folha & $\mathbf{N}$ & $\begin{array}{l}\text { IAC }-165 \\
\text { IAC }-4440\end{array}$ & $\begin{array}{l}Y=1,582+0,128 X \\
Y=1,803+0,073 X\end{array}$ & $\begin{array}{l}0,92 \\
0,70\end{array}$ & $\begin{array}{l}\star \star \\
\star \star\end{array}$ \\
\hline & & $\mathrm{P}$ & $\begin{array}{l}\text { IAC }-165 \\
\text { IAC }-4440\end{array}$ & $\begin{array}{l}Y=0,256+0,011 X \\
Y=0,173-0,0024 X+0,0015 X^{2}\end{array}$ & $\begin{array}{l}0,97 \\
0,99\end{array}$ & $\begin{array}{l}\star \star \\
\star \star\end{array}$ \\
\hline & & $\mathrm{Ca}$ & $\begin{array}{l}\text { IAC }-165 \\
\text { IAC }-4440\end{array}$ & $\begin{array}{l}Y=1,575-0,043 X \\
Y=1,147-0,067 X+0,0064 X^{2}\end{array}$ & $\begin{array}{l}0,90 \\
0,83\end{array}$ & $\begin{array}{c}\star \star \\
\star\end{array}$ \\
\hline & & $\mathrm{Cu}$ & $\begin{array}{l}\text { IAC- } 165 \\
\text { IAC }-4440\end{array}$ & $\begin{array}{l}Y=4,80+0,325 X \\
Y=5,025-0,806 X+0,07 X^{2}\end{array}$ & $\begin{array}{l}0,91 \\
0,99\end{array}$ & $\star \star *$ \\
\hline & & Mn & $\begin{array}{l}\text { IAC- } 165 \\
\text { IAC }-4440\end{array}$ & $\begin{array}{l}Y=329,7+14,987 X-1,516 X^{2} \\
Y=417,2-22,38 X+2,445 X^{2}\end{array}$ & $\begin{array}{l}0,72 \\
0,99\end{array}$ & $\begin{array}{c}\text { ns } \\
\star\end{array}$ \\
\hline & & $\mathrm{Ni}$ & $\begin{array}{l}\text { IAC }-165 \\
\text { IAC }-4440\end{array}$ & $\begin{array}{l}Y=35,30+52,762 X \\
Y=8,50+37,375 X\end{array}$ & $\begin{array}{l}0,99 \\
0,98\end{array}$ & $\begin{array}{l}\star \star * \\
\star \star\end{array}$ \\
\hline & $\begin{array}{l}\text { Colmo + } \\
\text { Perfilho }\end{array}$ & Mn & $\begin{array}{l}\text { IAC }-165 \\
\text { IAC }-4440\end{array}$ & $\begin{array}{l}Y=63,175-1,52 X+0,148 X^{2} \\
Y=54,825-5,42 X+0,867 X^{2}\end{array}$ & $\begin{array}{l}0,50 \\
0,99\end{array}$ & $\begin{array}{l}\text { ns } \\
\star \star\end{array}$ \\
\hline & & $\mathrm{zn}$ & $\begin{array}{l}\text { IAC- } 165 \\
\text { IAC }-4440\end{array}$ & $\begin{array}{l}Y=12,80-1,55 X+0,156 X^{2} \\
Y=12,05-1,55 X+0,219 X^{2}\end{array}$ & $\begin{array}{l}0,95 \\
0,99\end{array}$ & $\begin{array}{l}\star \star \\
\star \star\end{array}$ \\
\hline & Raiz & $\mathrm{Mn}$ & $\begin{array}{l}\text { IAC }-165 \\
\text { IAC }-4440\end{array}$ & $\begin{array}{l}Y=41,375-36,656 X+4,98 X^{2} \\
Y=13,825+2,394 X+0,29 X^{2}\end{array}$ & $\begin{array}{l}0,93 \\
0,95\end{array}$ & $\begin{array}{ll}\star \star \\
\text { ns }\end{array}$ \\
\hline & & $2 n$ & $\begin{array}{l}\text { IAC }-165 \\
\text { IAC }-4440\end{array}$ & $\begin{array}{l}Y=13,95-2,075 X+0,344 X^{2} \\
Y=12,15+1,10 X\end{array}$ & $\begin{array}{l}0,92 \\
0,93\end{array}$ & $\begin{array}{c}\star \star \\
*\end{array}$ \\
\hline
\end{tabular}

** Significativo ao nỉvel de $1 \%$

* Significativo ao nível de 5\%

ns Não significativo 

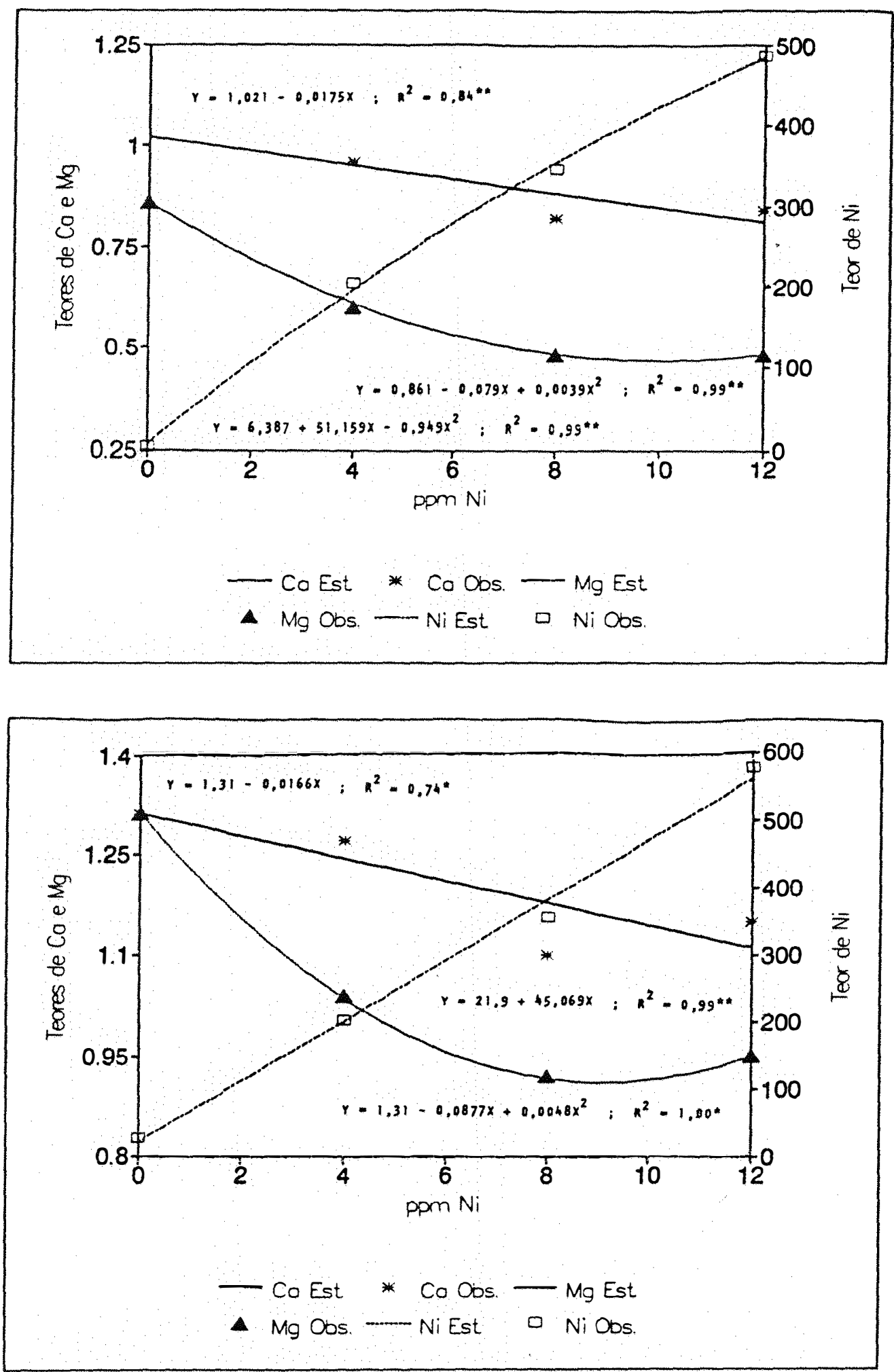

Figura 7. Relação entre os teores de nutrientes e níquel (\% e ppm) nas folhas de arroz para as duas coletas (perfilhamento e formação de grãos), e nỉveis de níquel (ppm) na solução nutritiva 
estes dados ajustaram-se a uma função linear. Na segunda coleta (formação de grãos), as doses de $\mathrm{Ni}$ afetaram negativamente os teores de Ca e Mn da folha, para as duas variedades, sendo os efeitos quadráticos. Na Figura 7, pode-se verificar com claridade os efeitos negativos dos niveis crescentes de $\mathrm{Ni}$ no teor foliar de $\mathrm{Ca}$ e $\mathrm{Mg}$, enquanto o teor de $\mathrm{Ni}$ na folha aumenta. Examinando-se os teores de $\mathrm{Ni}$ nas partes da planta de arroz (Apêndice 13), observaram-se que esses teores aumentaram em função aos niveis de $\mathrm{Ni}$ na solução nutritiva, sendo que a maior acumulação de Ni ocorre nas raĩzes. As equações de regressão (Apêndice 11), mostraram correlações positivas $(P \leq 0,01)$ entre os teores de $\mathrm{Ni}$ na matéria seca de arroz e as doses crescentes de $\mathrm{Ni}$ na solução nutritiva.

\subsubsection{Sintomatologia da toxidez de $\mathrm{Ni}$}

\subsubsection{Feijão}

Os sintomas de toxidez provocados pelo níquel no dois cul tivares de feijão (Carioca e IAPAR-14) surgiram, inicialmente, apenas nas doses mais elevadas ( 2 e 4ppm de $\mathrm{Ni}$ ). Após 7 dias do transplante das mudas para soluções nutritivas com $4 \mathrm{ppm}$ de $\mathrm{Ni}$, as folhas mais novas apresentaram clorose internerval e pequenos pontos irregulares necróticos, ligeira pigmentação bruno-avermelhada das folhas primärias, diminuição no crescimento da parte aérea e raízes. As raízes tornaram-se de uma cor parda escura, apresentando poucas raízes laterais. As plantas submetidas a $2 \mathrm{ppm}$ de $\mathrm{Ni}$ foram afetadas em menor grau, apresentando menor crescimento, ligeira clorose e encarquilhamento foliar. 
Após 14 dias, a intensidade dos sintomas aumentou, as plan tas sob $4 \mathrm{ppm}$ de $\mathrm{Ni}$ reduziram o seu crescimento, as folhas apresentam clo rose generalizada, a clorose estendu-se das folhas novas para as velhas, as folhas e entrenós ficaram menores, logo após, surgiram necroses no tecido na forma de pontos irregulares nas margens da folha, e ocasionalmente ocorreu desfolha prematura. As raízes, por sua vez, apresentam redução no seu crescimento, ausência de raízes laterais, de cor parda escura e quebradiças. Até o final do ensaio, não foi possível observar sintomas característicos da toxidez de $\mathrm{Ni}$ para plantas expostas a doses de lppm de $\mathrm{Ni}$ na solução nutritiva, somente o cultivar Carioca, no inicio, apresentou um ligeiro encarquilhamento.

\subsubsection{Arroz}

Nas duas variedades de arroz (IAC-165 e IAC-4440), os sin tomas de toxidez provocados pelas altas doses de $\mathrm{Ni}$ (8 e 12ppm), após 10 dias do transplante das mudas para as soluções nutritivas com níquelfo ram de menor crescimento, em relação à testemunha (sem Ni). Também obser vou-se clorose internerval nas folhas mais novas, estendendo-se para as folhas mais velhas. As raizes foram curtas e grossas "coralóides", de cor parda escura e quebradiças. Soluções nutritivas com doses menores de $\mathrm{Ni}$ (8ppm), apresentaram a mesma sintomatologia em menor intensidade.

Os sintomas de toxidez de $\mathrm{Ni}$ tardios incluem, alēm da redução no crescimento e clorose foliar, necrose das margens das folhas, diminuição no número de folhas, perfilhos e raỉzes, pontos necróticos nos perfilhos, e raízes curtas e grossas de cor parda escura e quebradiças. 
4.1.6. Estudos preliminares dos efeitos da toxidez de $\mathrm{Ni}$ nas fo1has de arroz e feijão, a nível ultraestrutural

Na Figura 8, apresentam-se os resultados dos estudos a ni vel de Microscopia Eletrônica dos efeitos tóxicos do Ni nas folhas · do feijoeiro e do arroz, cultivados em soluções nutritivas com 4 e 8ppm de $\mathrm{Ni}$, respectivamente. Verifica-se, a nível de ultraestruturas celulares, efeitos do $\mathrm{Ni}$, em relação ao controle (sem $\mathrm{Ni}$ ). Os maiores efeitos ocorreram nos cloroplastos, afetando-se a organização dos mesmos.

No feijoeiro, as altas doses de $\mathrm{Ni}$ induzem uma desorganização celular. Os cloroplastos diminuem o seu tamanho e número, não apresentam grãos de amido mas sim um aumento no número de glôbulos de plastídios.

No arroz, parece que o $\mathrm{Ni}$ afeta a organização dos cloroplastos na maioria das células, com distorção e expansão dos tilacoides. 

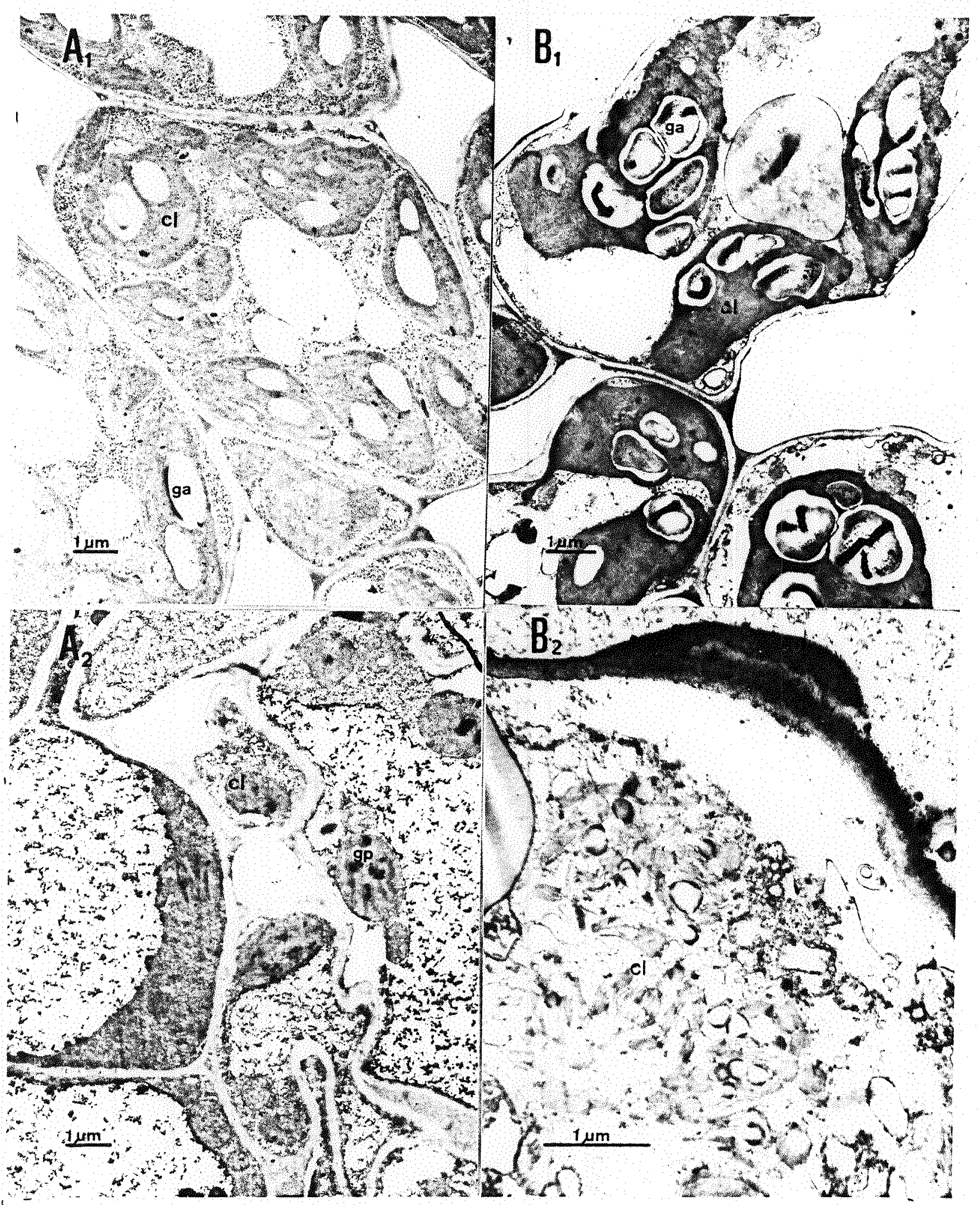

Figura 8. Eletrofotomicrografias de tecidos foliares de plantas de feijoeiro cv. Carioca (A) e de arroz v. IAC-165 (B) cultivadas em soluções nutritivas contendo $\mathrm{Ni}$ (ppm) nos níveis de $\mathrm{A}_{1}=0$; $\mathrm{A}_{2}=4 ; \mathrm{B}_{1}=0 ; \mathrm{B}_{2}=8$.

Abreviaturas: c1, cloroplasto; ga, grão de amido; gp, glóbulos de plastídeos 


\subsection{Ensaios em solos}

4.2.1. Avaliação dos efeitos da toxidez de Ni em três solos ácidos

\subsubsection{Feijão}

Na Tabela 8, Figura 9 e Apêndice 14, estão ilustrados os efeitos das doses de Ni sobre a produção de matéria seca de feijão, coletado por ocasião da formação de grãos, em três solos ácidos. Em geral, - Vertissolo (V) apresentou as maiores produções, seguido do Latossolo Roxo distrófico (LRd), e por ültimo da Terra Roxa Estruturada (TE). No Vertissolo, verificou-se reduções significativas na produção de matéria seca com a dose de $120 \mathrm{ppm}$ de $\mathrm{Ni}$, enquanto que no LRd e TE estas reduções significativas ocorreram a partir dos niveis de 60 e 30ppm de Ni, respectivamente. A medida que as doses de $\mathrm{Ni}$ aplicadas ao solo aumentam, ocorre a diminuição na produção de matéria seca. Analisando a produção de matéria seca total de feijão, verifica-se que os dados obtidos na TE se ajustaram a uma função linear, enquanto que os dados obtidos no $V$ e LRd apresentam um efeito quadrātico. 
Tabela 8. Produção de matéria seca em feijão cultivar Carioca, em função dos niveis de níquel, em três solos ${ }^{1}$

\begin{tabular}{|c|c|c|c|c|c|c|c|}
\hline Solos & $\mathrm{Ni}$ & Folha & $\begin{array}{l}\text { Caule + } \\
\text { Ramo }\end{array}$ & Raiz & Casca & Grão & Total \\
\hline & $\mathrm{ppm}$ & $\cdots$ & - & $-\cdots$ & g/vaso & $\cdots-\cdots$ & $-\infty-\infty-\cdots$ \\
\hline \multirow[t]{4}{*}{ V } & 0 & $6,59 \mathrm{bc}$ & $4,07 \mathrm{bc}$ & $3,89 \mathrm{~b}$ & $2,27 \mathrm{~b}$ & $5,50 \mathrm{~b}$ & $22,32 b$ \\
\hline & 30 & $6,73 \mathrm{~b}$ & $4,00 \quad c$ & $4,90 a$ & $2,79 a$ & $5,56 \mathrm{~b}$ & $23,97 a$ \\
\hline & 60 & $7,09 a$ & $4,28 b$ & $5,15 a$ & $2,35 \mathrm{~b}$ & $6,08 a$ & $24,95 a$ \\
\hline & 120 & $6,29 c$ & $4,86 a$ & $5,19 a$ & $2,19 b$ & $1,51 \mathrm{c}$ & $20,04 \quad c$ \\
\hline \multirow[t]{4}{*}{ LRd } & 0 & $3,38 a$ & $1,86 a$ & $1,23 a b$ & $1,18 a$ & $5,52 a$ & $13,16 a$ \\
\hline & 30 & $2,94 \mathrm{~b}$ & $2,05 a$ & $1,65 a$ & $1,20 a$ & $4,74 \mathrm{~b}$ & $12,58 a$ \\
\hline & 60 & $2,70 b$ & $2,02 a$ & $1,69 a$ & $1,11 \mathrm{a}$ & 2,28 & $9,79 \mathrm{~b}$ \\
\hline & 120 & $1,28 \quad c$ & $1,34 \mathrm{~b}$ & $0,78 \mathrm{~b}$ & $0,10 \mathrm{~b}$ & $0,00 \quad d$ & $3,50 \quad c$ \\
\hline \multirow[t]{4}{*}{$\mathrm{TE}$} & 0 & $3,29 a$ & $1,63 a$ & $1,87 a$ & $1,09 a$ & $1,58 \mathrm{a}$ & $9,45 a$ \\
\hline & 30 & $2,00 \mathrm{~b}$ & $1,33 \mathrm{~b}$ & $1,27 \mathrm{~b}$ & $0,83 b$ & $0,60 \mathrm{~b}$ & $6,02 \mathrm{~b}$ \\
\hline & 60 & $1,35 \quad c$ & $1,34 \mathrm{~b}$ & $1,51 \mathrm{ab}$ & $0,74 b$ & $0,00 \quad c$ & $4,94 \mathrm{c}$ \\
\hline & 120 & 0,13 & 0,13 & $0,05 \mathrm{c}$ & $0,00 \quad c$ & $0,00 \quad c$ & 0,31 \\
\hline $\mathrm{DMS}_{\mathrm{AxB}}^{2}$ & $(5 \%)$ & 0,33 & 0,27 & 0,50 & 0,25 & 0,51 & 1,01 \\
\hline C.V. \% & & 3,9 & 5,0 & 9,1 & 8,4 & 8,1 & 3,5 \\
\hline
\end{tabular}

1 Mëdia de 3 repetições

2 Comparação de médias pelo teste de Tukey, da interação níveis de Ni x so los 


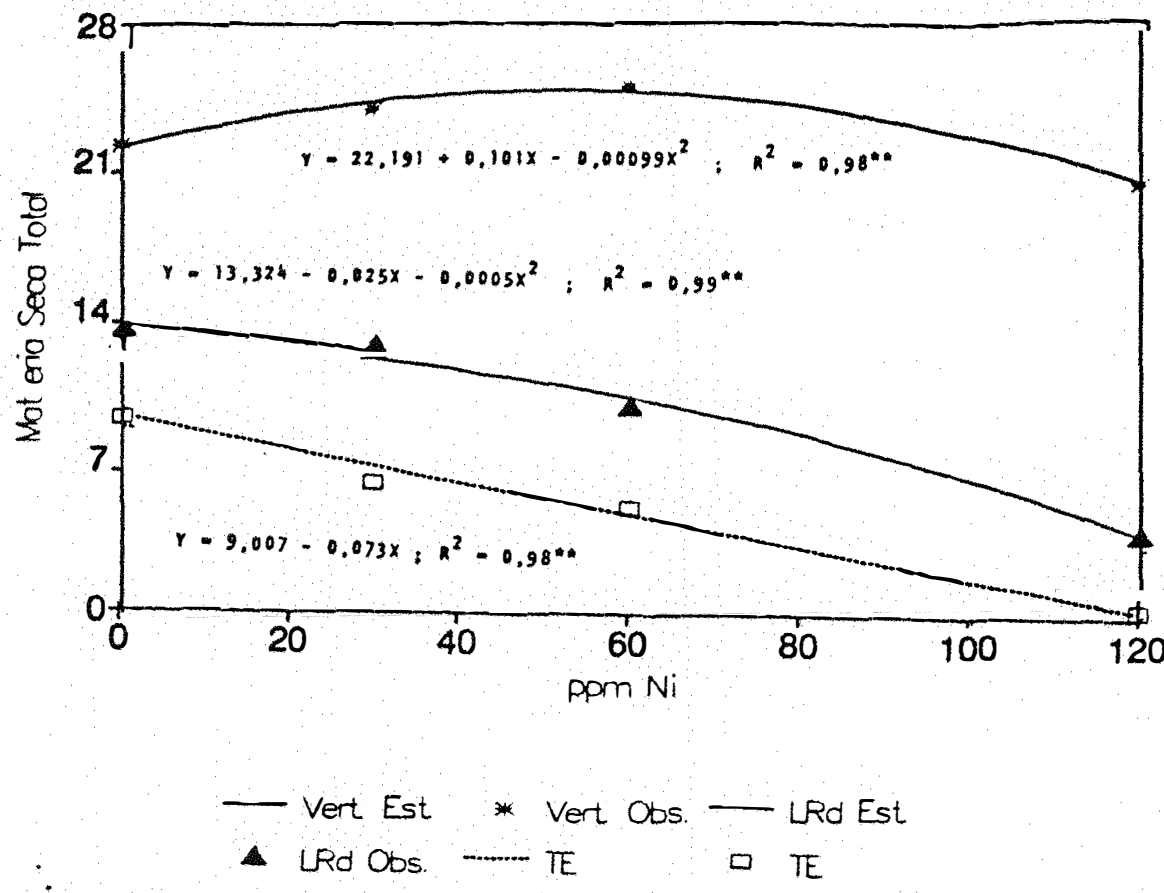

Figura 9. Relação entre a produção de matēria seca total (g/vaso) feijoeiro, e níveis de níquel (ppm) em três solos ácidos

Os teores de nutrientes (Tabela 9, Figura 10 e Apêndices 15 e 16) tambëm foram afetados pelas doses de $\mathrm{Ni}$, sendo que a maioria (N, $\mathrm{P}, \mathrm{K}, \mathrm{S}$ e $\mathrm{Fe}$ ) aumenta a sua concentração na planta, outros (Ca, Mn e $\mathrm{Zn}$ ) diminuem, enquanto que $\circ \mathrm{Mg}$ e $\circ \mathrm{Cu}$ mostraram-se indiferentes. As anālises de regressão determinadas mostraram efeitos lineares negativos no teor de Mn na folha de feijão no LRd, enquanto que na TE este ef eito foi quadrätico. No Vertissolo os dados sobre os teores de nutrientes não se ajustaram a nenhuma função matemática, em relação às doses de Ni. 
Tabela 9. Equações de regressão entre teores de nutrientes e níquel (\% e ppm) de feijoeiro ( $Y$ ), e ppm de níquel (X) em três solos ácidos

\begin{tabular}{|c|c|c|c|c|c|c|}
\hline & Variävel & & & Equação de Regressão & $R^{2}$ & $F$ \\
\hline Parte & Nutriente & Solos & & & & \\
\hline \multirow[t]{4}{*}{ Folha } & $\mathrm{N}$ & $\begin{array}{l}V \\
\text { LRd } \\
\text { TE }\end{array}$ & $\begin{array}{l}Y= \\
Y= \\
Y=\end{array}$ & $\begin{array}{l}=1,788+0,0049 x-0,00002 x^{2} \\
=1,451+0,0104 x \\
=1,608+0,022 x-0,00014 x^{2}\end{array}$ & $\begin{array}{l}0,51 \\
0,99 \\
0,76\end{array}$ & $\begin{array}{l}\text { ns } \\
\star \star \\
\text { ns }\end{array}$ \\
\hline & k & $\begin{array}{l}V \\
\text { LRd } \\
\text { TE }\end{array}$ & $\begin{array}{l}Y= \\
Y= \\
Y=\end{array}$ & $\begin{array}{l}=1,027-0,013 x+0,00009 x^{2} \\
=2,068+0,037 x-0,00014 x^{2} \\
=1,957+0,0275 x-0,00015 x^{2}\end{array}$ & $\begin{array}{l}0,95 \\
0,998 \\
0,95\end{array}$ & $\begin{array}{l}\text { ns } \\
\star \star \\
\star \star\end{array}$ \\
\hline & Mn & $\begin{array}{l}V \\
\text { LRd } \\
\text { TE }\end{array}$ & $\begin{array}{l}Y= \\
Y= \\
Y=\end{array}$ & $\begin{array}{l}=177,26+2,192 x-0,019 x^{2} \\
=515,40-1,115 x \\
=1532,22-23,307 x+0,094 x^{2}\end{array}$ & $\begin{array}{l}0,98 \\
0,79 \\
0,95\end{array}$ & $\begin{array}{l}\text { ns } \\
\text { ns } \\
\star \star\end{array}$ \\
\hline & $\mathrm{Ni}$ & $\begin{array}{l}v \\
\text { LRd } \\
\text { TE }\end{array}$ & $\begin{array}{l}Y= \\
Y= \\
Y=\end{array}$ & $\begin{array}{l}=24,16+2,456 x-0,015 x^{2} \\
=31,19+0,552 x+0,014 x^{2} \\
=-1,70+3,799 x\end{array}$ & $\begin{array}{l}0,98 \\
0,99 \\
0,995\end{array}$ & $\begin{array}{l}\star \star \\
\star \star \\
\star \star\end{array}$ \\
\hline \multirow[t]{7}{*}{$\begin{array}{l}\text { Caule + } \\
\text { Ramo }\end{array}$} & $\mathrm{N}$ & $\begin{array}{l}V \\
\text { LRd } \\
\text { TE }\end{array}$ & $\begin{array}{l}Y= \\
Y= \\
Y=\end{array}$ & $\begin{array}{l}=1,154-0,006 x+0,00006 x^{2} \\
=0,759+0,0086 x \\
=0,797+0,019 x-0,0001 x^{2}\end{array}$ & $\begin{array}{l}0,97 \\
0,97 \\
0,98\end{array}$ & $\begin{array}{l}\text { ns } \\
\star \star \\
\star\end{array}$ \\
\hline & $\mathrm{Ca}$ & $\begin{array}{l}V \\
\text { LRd } \\
T E\end{array}$ & $\begin{array}{l}Y= \\
Y= \\
Y=\end{array}$ & $\begin{array}{l}=1,88-0,0033 x \\
=1,266-0,0045 x \\
=1,201+0,0064 x-0,00007 x^{2}\end{array}$ & $\begin{array}{l}0,59 \\
0,88 \\
0,80\end{array}$ & $\begin{array}{l}\star \star * \\
\star \star \\
\star \star\end{array}$ \\
\hline & $\mathrm{Mg}$ & $\begin{array}{l}V \\
\text { LRd } \\
\text { TE }\end{array}$ & $\begin{array}{l}Y= \\
Y= \\
Y=\end{array}$ & $\begin{array}{l}=1,137+0,0034 x-0,00005 x^{2} \\
=0,808+0,0012 x-0,000005 x^{2} \\
=0,803+0,004 x\end{array}$ & $\begin{array}{l}0,99 \\
0,43 \\
0,96\end{array}$ & $\begin{array}{l}\star \star \\
\text { ns } \\
\star \star\end{array}$ \\
\hline & $\mathrm{Fe}$ & $\begin{array}{l}\mathrm{V} \\
\text { LRd } \\
\mathrm{TE}\end{array}$ & $\begin{array}{l}Y= \\
Y= \\
Y=\end{array}$ & $\begin{array}{l}=169,47-0,461 x+0,011 x^{2} \\
=279,54-0,611 x-0,0026 x^{2} \\
=258,13-3,554 x+0,068 x^{2}\end{array}$ & $\begin{array}{l}0,96 \\
0,94 \\
0,91\end{array}$ & $\begin{array}{l}\text { ns } \\
\text { ns } \\
\star \star\end{array}$ \\
\hline & Mn & $\begin{array}{l}V \\
\text { LRd } \\
\text { TE }\end{array}$ & $\begin{array}{l}Y= \\
Y= \\
Y=\end{array}$ & $\begin{array}{l}=78,80-0,418 x \\
=76,754-1,078 x+0,0058 x^{2} \\
=427,30-3,548 x\end{array}$ & $\begin{array}{l}0,60 \\
0,98 \\
0,70\end{array}$ & $\begin{array}{l}\text { ns } \\
\text { ns } \\
\star \star\end{array}$ \\
\hline & $2 n$ & $\begin{array}{l}\text { V } \\
\text { LRd } \\
\text { TE }\end{array}$ & $\begin{array}{l}Y= \\
Y= \\
Y=\end{array}$ & $\begin{array}{l}=37,90-0,143 x \\
=12,23+0,113 x-0,0004 x^{2} \\
=39,18-0,513 x+0,0042 x^{2}\end{array}$ & $\begin{array}{l}0,89 \\
0,97 \\
0,84\end{array}$ & $\begin{array}{l}\star \star \\
\text { ns } \\
\star \star\end{array}$ \\
\hline & $\mathrm{Ni}$ & $\begin{array}{l}\mathrm{V} \\
\text { LRd } \\
\text { TE }\end{array}$ & $\begin{array}{l}Y= \\
Y= \\
Y=\end{array}$ & $\begin{array}{l}=34,10+0,705 x \\
=50,10+1,098 x \\
=33,927+1,324 x+0,0326 x^{2}\end{array}$ & $\begin{array}{l}0,81 \\
0,87 \\
0,98\end{array}$ & $\begin{array}{l}\star \star * \\
\star \star \\
\star \star\end{array}$ \\
\hline \multirow[t]{6}{*}{ Raiz } & $P$ & $\begin{array}{l}V \\
\text { LRd } \\
\text { TE }\end{array}$ & $\begin{array}{l}Y= \\
Y= \\
Y=\end{array}$ & $\begin{array}{l}=0,146-0,0009 x+0,000008 x^{2} \\
=0,11+1,00 x \\
=0,108+0,0003 x-0,000002 x^{2}\end{array}$ & $\begin{array}{l}0,79 \\
0,00 \\
0,66\end{array}$ & $\begin{array}{l}\star \star \\
\text { ns } \\
\text { ns }\end{array}$ \\
\hline & $\mathrm{K}$ & $\begin{array}{l}V \\
\text { LRd } \\
\text { TE }\end{array}$ & $\begin{array}{l}Y= \\
Y= \\
Y=\end{array}$ & $\begin{array}{l}=0,377-0,0048 x+0,000032 x^{2} \\
=-0,04+0,0065 x \\
=0,081+0,011 x-0,00006 x^{2}\end{array}$ & $\begin{array}{l}0,71 \\
0,82 \\
0,96\end{array}$ & 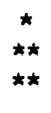 \\
\hline & $\mathrm{Mg}$ & $\begin{array}{l}V \\
\text { LRd } \\
\text { TE }\end{array}$ & $\begin{array}{l}Y= \\
Y= \\
Y=\end{array}$ & $\begin{array}{l}=0,74+0,00082 x-0,00001 x^{2} \\
=0,51+0,0024 x-0,00002 x^{2} \\
=0,43+0,0012 x\end{array}$ & $\begin{array}{l}0,58 \\
0,38 \\
0,65\end{array}$ & $\begin{array}{c}\mathrm{ns} \\
* \\
\star *\end{array}$ \\
\hline & Mn & $\begin{array}{l}V \\
\text { LRd } \\
\text { TE }\end{array}$ & $\begin{array}{l}Y= \\
Y= \\
Y=\end{array}$ & $\begin{array}{l}=165,114+1,131 x-0,0063 x^{2} \\
=100,9+0,2924 x \\
=258,7-1,263 x\end{array}$ & $\begin{array}{l}0,996 \\
0,52 \\
0,83\end{array}$ & $\begin{array}{l}\mathrm{ns} \\
\mathrm{ns} \\
\star \star\end{array}$ \\
\hline & $\mathrm{Zn}$ & $\begin{array}{l}v \\
\text { LRd } \\
\text { TE }\end{array}$ & $\begin{array}{l}Y= \\
Y= \\
Y=\end{array}$ & $\begin{array}{l}=124,2-1,747 x+0,01 x^{2} \\
=80,54-1,436 x+0,0099 x^{2} \\
=57,43-1,025 x+0,0115 x^{2}\end{array}$ & $\begin{array}{l}0,91 \\
0,84 \\
0,998\end{array}$ & $\begin{array}{l}\star \\
\star \\
\star\end{array}$ \\
\hline & $\mathrm{Ni}$ & $\begin{array}{l}v \\
\text { LRd } \\
\text { TE }\end{array}$ & $\begin{array}{l}Y= \\
Y= \\
Y=\end{array}$ & $\begin{array}{l}=40,90+1,928 x \\
=40,295+0,845 x+0,0304 x^{2} \\
=87,268-4,089 x+0,117 x^{2}\end{array}$ & $\begin{array}{l}0,996 \\
0,996 \\
0,98\end{array}$ & $\begin{array}{l}* \star \\
\star * \\
\star *\end{array}$ \\
\hline
\end{tabular}

** Significativo ao nivel de $1 \%$

* Significativo ao nỉvel de $5 \%$

ns Não significativo 

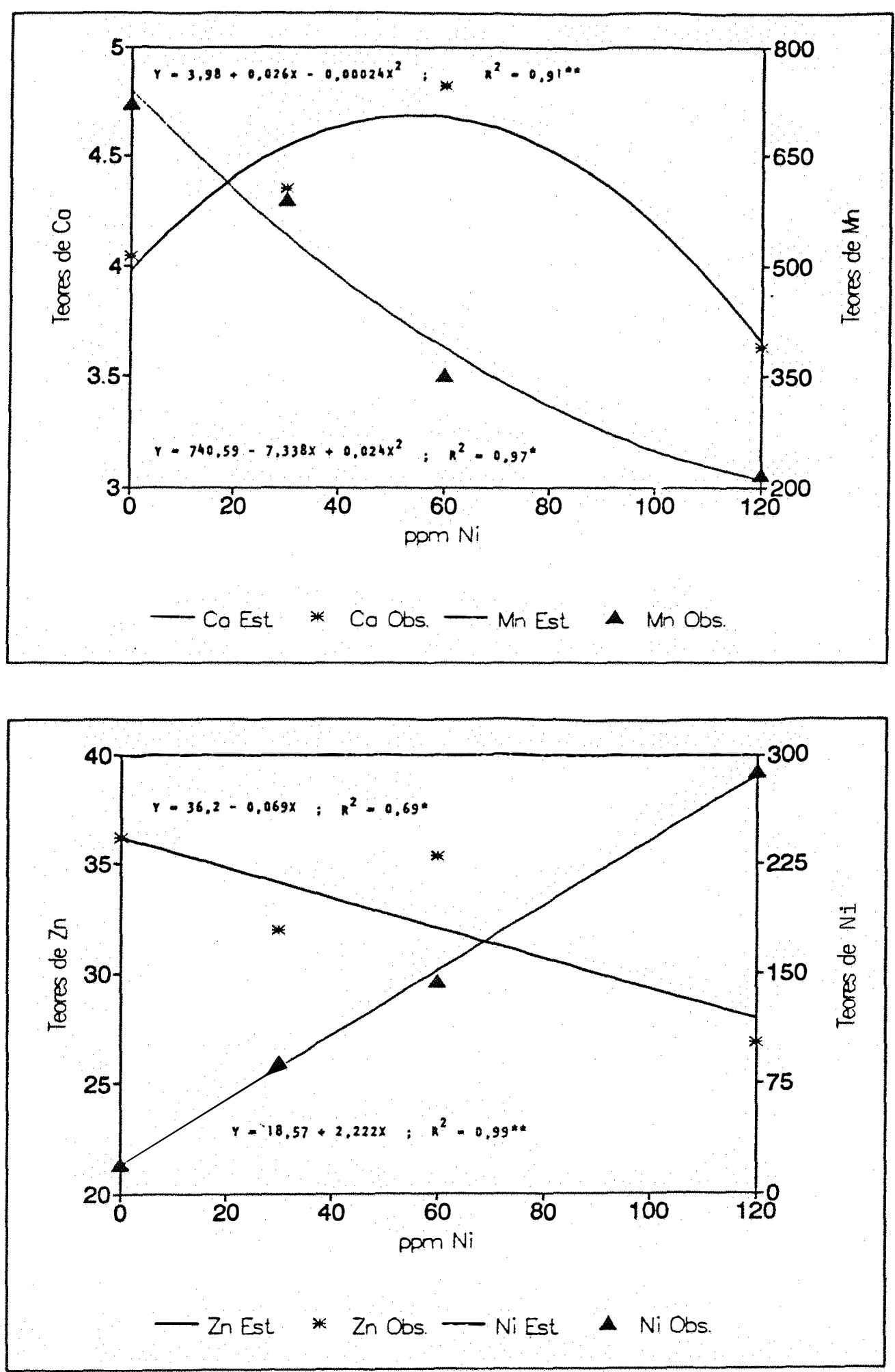

Figura 10. Relação entre teores de nutrientes e níquel (\% e ppm) nas fothas de feijoeiro, e níveis de níquel (ppm) no solo 
Em geral, pode-se observar que nos ensaios em solos (Figura 10), existem correlações negativas significativas entre os teores foliares de Ca, Mn e $\mathrm{Zn}$ e as doses de $\mathrm{Ni}$ aplicados ao solo. Os teores de Fe na raiz foram muito elevados, provavelmente devido a contaminações com partículas de solo, no momento da coleta do material. Os baixos teores foliares de $P$ nos solos LRd e TE justificam em parte sua menor capacidade de produção, em relação ao solo Vertissolo (V).

Os teores de $\mathrm{Ni}$ (Tabela 9, Figura 10 e Apêndices 15 e 17), foram afetados em relação direta com as doses de $\mathrm{Ni}$ utilizadas, em todas as partes da planta. Nota-se que o maior acúmulo de $\mathrm{Ni}$ ocorre na raiz. Fazendo uma comparação entre os três solos (V, LRd e TE), os teores de $\mathrm{Ni}$ nas diferentes partes da planta foram maiores nas plantas que cresceram na TE, seguido do LRd, e por ültimo do V. Estas diferenças nos teores de $\mathrm{Ni}$ na planta foram notórias a partir da dose de $60 \mathrm{ppm}$ de $\mathrm{Ni}$. As equações de regressão mostram um efeito positivo 1inear $(P \leq 0,01)$ das doses de $\mathrm{Ni}$ sobre o teor de $\mathrm{Ni}$ nas folhas. 


\subsubsection{Arroz}

Na Tabela 10, Figura 11 e Apêndice 18, estão ilustrados os efeitos das doses de $\mathrm{Ni}$ sobre a produção de matéria seca de arroz, coletado por ocasião da formação de grãos, em três solos ácidos. Verifica-se nos 3 solos, um efeito negativo significativo $(P \leq 0,05)$ das doses crescentes de $\mathrm{Ni}$ sobre a produção de matéria seca. Entretanto, a produção de matéria seca no Vertissolo foi maior em comparação aos outros solos estudados (LRd e TE). As menores produções ocorreram na TE com doses de $120 \mathrm{ppm}$ de $\mathrm{Ni}$. Por outro lado, as análises de regressão (Apêndice 18), mostraram diminuições lineares significativas $(\mathrm{P} \leq 0,01)$ na produção de matéria seca de folhas, colmo + perfilhos e total no LRd, em relação às dases de Ni. Enquanto que nos outros dois solos (V e TE), verificou-se um efeito quadrático das doses de $\mathrm{Ni}$ sobre a produção de matēria seca. Também, constatou-se pelo teste de Tukey a 5\% que não houve diferenças significativas entre as doses de 0 e 30ppm de $\mathrm{Ni}$ na produção de matéria seca no LRd e TE. No Vertissolo, as doses de 60 e $120 \mathrm{ppm}$ de $\mathrm{Ni}$ não foram significativamente diferentes na produção de matéria seca para todas as partes da planta.

Os efeitos dos níveis de $\mathrm{Ni}$ sobre os teores de nutrientes (Tabela 11, Figura 12 e Apêndices 19 e 20) nas partes da planta de arroz, mostraram diversos comportamentos. Verificou-se um aumento dos teores de $\mathrm{N}$ e $\mathrm{K}$. Os teores de $\mathrm{P}, \mathrm{S}$ e $\mathrm{Cu}$ não foram afetados, enquanto que os teores de $\mathrm{Ca}, \mathrm{Mg}$, Fe, Mn e $\mathrm{Zn}$ diminuiram por ação das doses de Ni. Nas folhas, observou-se que as doses crescentes de $\mathrm{Ni}$ diminuiram os teores de $\mathrm{Ca}, \mathrm{Mg}$, Mn e $\mathrm{Zn}$. As análises de regressão mostram reduções 
Tabela 10. Produção de matēria seca em arroz variedade IAC-165, em função dos nîveis de níquel em três solos ${ }^{1}$

\begin{tabular}{|c|c|c|c|c|c|c|c|}
\hline Solos & $\mathrm{Ni}$ & Folha & $\begin{array}{l}\text { Colmo }+ \\
\text { Perfilho }\end{array}$ & Raiz & Raquis & Grão & Tota 1 \\
\hline & $\mathrm{ppm}$ & $-\cdots$ & - & 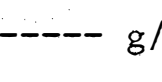 & aso - - - & - - - - & $\ldots$ \\
\hline \multirow[t]{4}{*}{ V } & 0 & $8,25 a$ & $12,45 a$ & $9,80 a$ & $1,62 a$ & $3,28 a$ & $35,40 a$ \\
\hline & 30 & $5,36 \mathrm{~b}$ & $9,95 \mathrm{~b}$ & $8,28 b$ & $1,55 a$ & $2,38 \mathrm{~b}$ & $27,51 \mathrm{~b}$ \\
\hline & 60 & $5,03 \mathrm{bc}$ & $8,01 \quad c$ & $7,73 \mathrm{~b}$ & $1,42 \mathrm{~b}$ & $0,97 \quad c$ & 23,17 \\
\hline & 120 & $4,59 \mathrm{c}$ & $7,36 \mathrm{c}$ & $7,16 b$ & $1,17 \quad c$ & $1,21 \mathrm{c}$ & 21,49 \\
\hline \multirow[t]{4}{*}{ LRd } & 0 & $4,09 a$ & $5,35 a$ & $4,62 a$ & $0,78 a$ & $1,86 a$ & $16,71 a$ \\
\hline & 30 & $3,62 \mathrm{ab}$ & $4,97 a$ & $4,82 a$ & $0,70 \mathrm{ab}$ & $1,17 \mathrm{~b}$ & $15,29 a b$ \\
\hline & 60 & $3,35 \mathrm{~b}$ & $4,85 a$ & $4,21 a$ & $0,67 \mathrm{~b}$ & $0,78 \mathrm{~b}$ & $13,86 \mathrm{bc}$ \\
\hline & 120 & $2,80 \quad c$ & $3,76 \mathrm{~b}$ & $4,17 a$ & $0,40 c$ & $0,94 \mathrm{~b}$ & $12,07 \quad c$ \\
\hline \multirow[t]{4}{*}{$\mathrm{TE}$} & 0 & $3,95 a$ & $5,71 a$ & $4,89 a$ & $0,78 a$ & $2,17 a$ & $17,49 a$ \\
\hline & 30 & $3,53 \mathrm{ab}$ & $5,32 a$ & $4,86 a$ & $0,75 a$ & $1,74 a$ & $16,20 \mathrm{ab}$ \\
\hline & 60 & $2,99 \mathrm{~b}$ & $4,41 \mathrm{~b}$ & $4,68 a$ & $0,57 \mathrm{~b}$ & $1,80 a$ & $14,45 \mathrm{~b}$ \\
\hline & 120 & $1,61 \mathrm{c}$ & $2,65 \mathrm{c}$ & $2,78 b$ & $0,24 \quad c$ & $0,11 \mathrm{~b}$ & 7,38 \\
\hline $\mathrm{DMS}_{\mathrm{AxB}}^{2}$ & $(5 \%)$ & 0,55 & 0,71 & 1,11 & 0,11 & 0,57 & 1,94 \\
\hline C.V. \% & & 5,9 & 5,0 & 8,7 & 9,0 & 16,3 & 4,6 \\
\hline
\end{tabular}

1 Média de 3 repetições

2 Comparação de médias pelo teste de Tukey, da interação nỉveis de $\mathrm{Ni} x$ solos 


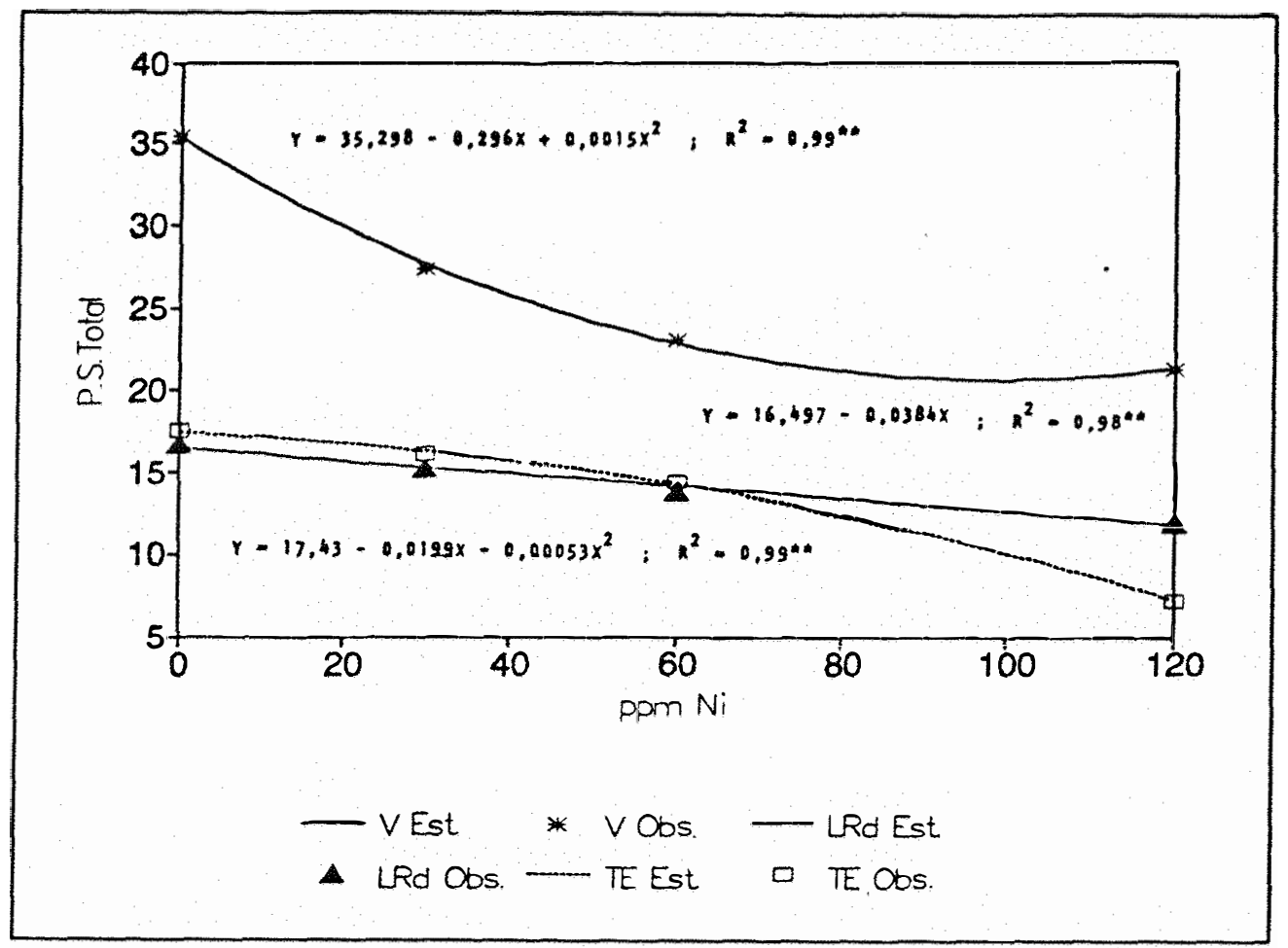

Figura 11. Relação entre a produção de matéria seca total (g/vaso) em arroz, e nïveis de níquel (pm) em três solos äcidos

lineares significativas $(P \leq 0,01)$ nos teores de $\mathrm{Mg}$, Mn e $\mathrm{Zn}$ das foThas, em relação às doses crescentes de $\mathrm{Ni}$. No entanto, os teores foliares de Ca se ajustaram melhor a uma função quadrätica.

Com respeito ao teor de $\mathrm{Ni}$ (Tabela 11 e Apêndices 19 e 21) na matéria seca de arroz, em função aos níveis de Ni aplicados ao solo, pode-se notar uma relação direta entre o teor e a dose de Ni. Tam bém, observou-se uma maior acumulação de $\mathrm{Ni}$ nas raízes. Comparando os três solos, os teores de Ni foram maiores em plantas que cresceräm na $\mathrm{TE}$, seguida do LRd, sendo que no Vertissolo os teores de $\mathrm{Ni}$ forām os 
Tabela 11. Equações de regressão entre teores de nutrientes e nĩquel (\% e ppm) em arroz (Y), e ppm de níquel (X) em três solos ácidos

\begin{tabular}{|c|c|c|c|c|c|}
\hline & Variäve1 & & Equação de Regressão & $R^{2}$ & $\mathrm{~F}$ \\
\hline Parte & Nutriente & Solos & & & \\
\hline \multirow[t]{4}{*}{ Foiha } & $\mathrm{K}$ & $\begin{array}{l}\text { V } \\
\text { LRd } \\
\text { TE }\end{array}$ & $\begin{array}{l}Y=1,027+0,048 X-0,00026 X^{2} \\
Y=3,27+0,0032 X \\
Y=2,07+0,0089 X\end{array}$ & $\begin{array}{l}0,996 \\
0,54 \\
0,86\end{array}$ & $\begin{array}{l}* * \\
* \\
* *\end{array}$ \\
\hline & $\mathrm{Ca}$ & $\begin{array}{l}\text { V } \\
\text { LRd } \\
\text { TE }\end{array}$ & $\begin{array}{l}Y=1,69-0,0036 X \\
Y=0,92+0,0082 X-0,00005 X^{2} \\
Y=1,738-0,0056 X\end{array}$ & $\begin{array}{l}0,87 \\
0,97 \\
0,89\end{array}$ & $\begin{array}{l}* * \\
* \\
* *\end{array}$ \\
\hline & $\mathrm{Mn}$ & $\begin{array}{l}\mathrm{V} \\
\mathrm{LRd} \\
\mathrm{TE}\end{array}$ & $\begin{array}{l}Y=1028,34+7,11 X-0,091 X^{2} \\
Y=1859,0-8,60 X \\
Y=4800,0-35,024 X\end{array}$ & $\begin{array}{l}0,46 \\
0,88 \\
0,98\end{array}$ & $\begin{array}{l}\mathrm{ns} \\
* \\
* *\end{array}$ \\
\hline & $\mathrm{Ni}$ & $\begin{array}{l}\mathrm{V} \\
\mathrm{LRd} \\
\mathrm{TE}\end{array}$ & $\begin{array}{l}Y=20,20+0,415 X \\
Y=26,60+0,769 X \\
Y=6,595+2,767 X-0,0087 X^{2}\end{array}$ & $\begin{array}{l}0,99 \\
0,98 \\
0,98\end{array}$ & $\begin{array}{l}* * \\
* * \\
* *\end{array}$ \\
\hline \multirow[t]{2}{*}{$\begin{array}{l}\text { Colmo + } \\
\text { Perfilho }\end{array}$} & $\mathrm{K}$ & $\begin{array}{l}V \\
\text { LRd } \\
\text { TE }\end{array}$ & $\begin{array}{l}Y=1,743+0,0378 X-0,00017 X^{2} \\
Y=4,437-0,0103 X+0,000098 X^{2} \\
Y=2,77+0,007 X-0,000056 X^{2}\end{array}$ & $\begin{array}{l}0,999 \\
0,73 \\
0,74\end{array}$ & $\begin{array}{l}* \\
\text { ns } \\
\text { ns }\end{array}$ \\
\hline & $\mathrm{Ni}$ & $\begin{array}{l}V \\
\text { LRd } \\
\text { TE }\end{array}$ & $\begin{array}{l}Y=11,80+0,678 X \\
Y=14,70+1,101 X \\
Y=10,76+3,41 X-0,0162 X^{2}\end{array}$ & $\begin{array}{l}0,98 \\
0,99 \\
0,999\end{array}$ & $\begin{array}{l}* * \\
* * \\
* *\end{array}$ \\
\hline \multirow[t]{3}{*}{ Raiz } & $\mathrm{Ca}$ & $\begin{array}{l}\mathrm{V} \\
\mathrm{LRd} \\
\mathrm{TE}\end{array}$ & $\begin{array}{l}Y=0,445+0,0035 X-0,000021 X^{2} \\
Y=0,49-0,00406 X+0,000026 X^{2} \\
Y=0,51-0,0014 X+0,00001 X^{2}\end{array}$ & $\begin{array}{l}0,81 \\
0,81 \\
0,34\end{array}$ & $\begin{array}{l}* \\
* * \\
\text { ns }\end{array}$ \\
\hline & $2 \mathrm{n}$ & $\begin{array}{l}V \\
\text { LRd } \\
\text { TE }\end{array}$ & $\begin{array}{l}Y=170,30-0,846 X \\
Y=61,10-0,207 X \\
Y=51,07-0,284 X+0,002 X^{2}\end{array}$ & $\begin{array}{l}0,82 \\
0,97 \\
0,33\end{array}$ & $\begin{array}{l}* * \\
\mathrm{~ns} \\
\mathrm{~ns}\end{array}$ \\
\hline & $\mathrm{Ni}$ & $\begin{array}{l}V \\
\text { LRd } \\
\text { TE }\end{array}$ & $\begin{array}{l}Y=29,10+1,391 X \\
Y=29,20+3,182 X \\
Y=35,00+3,552 X\end{array}$ & $\begin{array}{l}0,99 \\
0,98 \\
0,99\end{array}$ & $\begin{array}{l}* * \\
* * \\
* *\end{array}$ \\
\hline
\end{tabular}

** Significativo ao nîvel de $1 \%$

* Significativo ao nivel de $5 \%$

ns Não significativo 


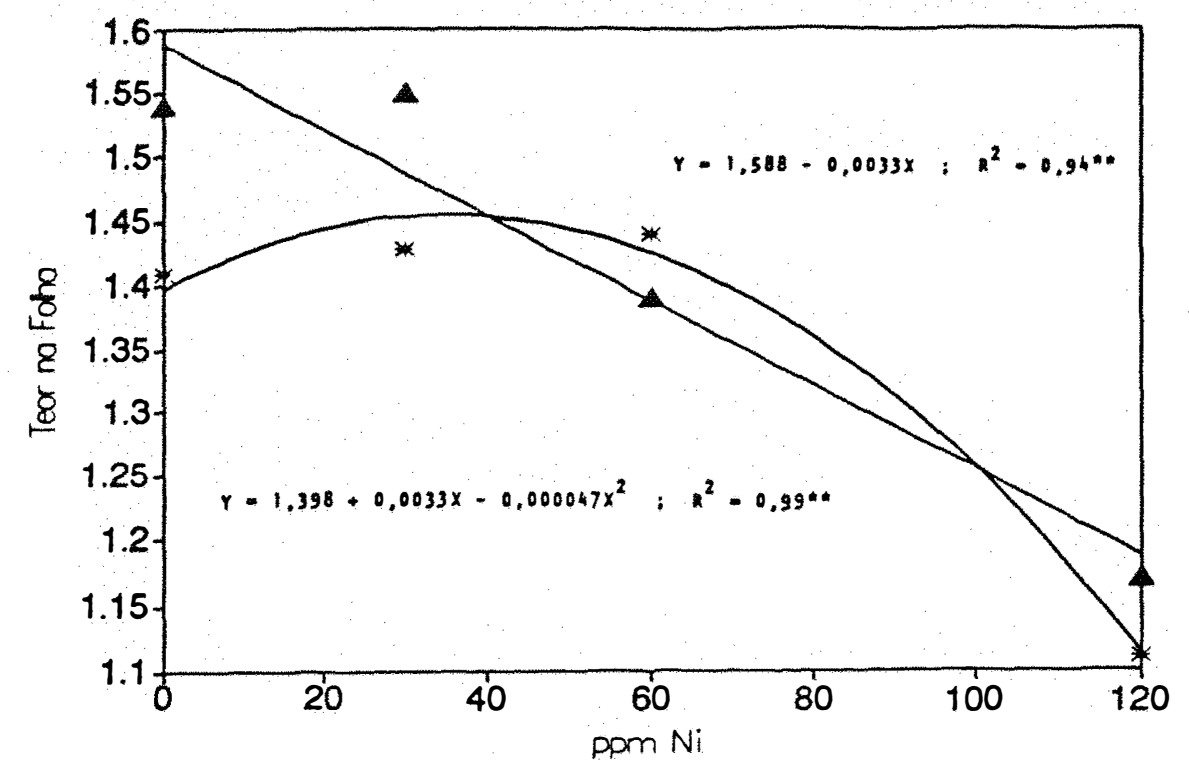

-CoEst * Co Obs. - Mg Est $\triangle$ Mg Obs.

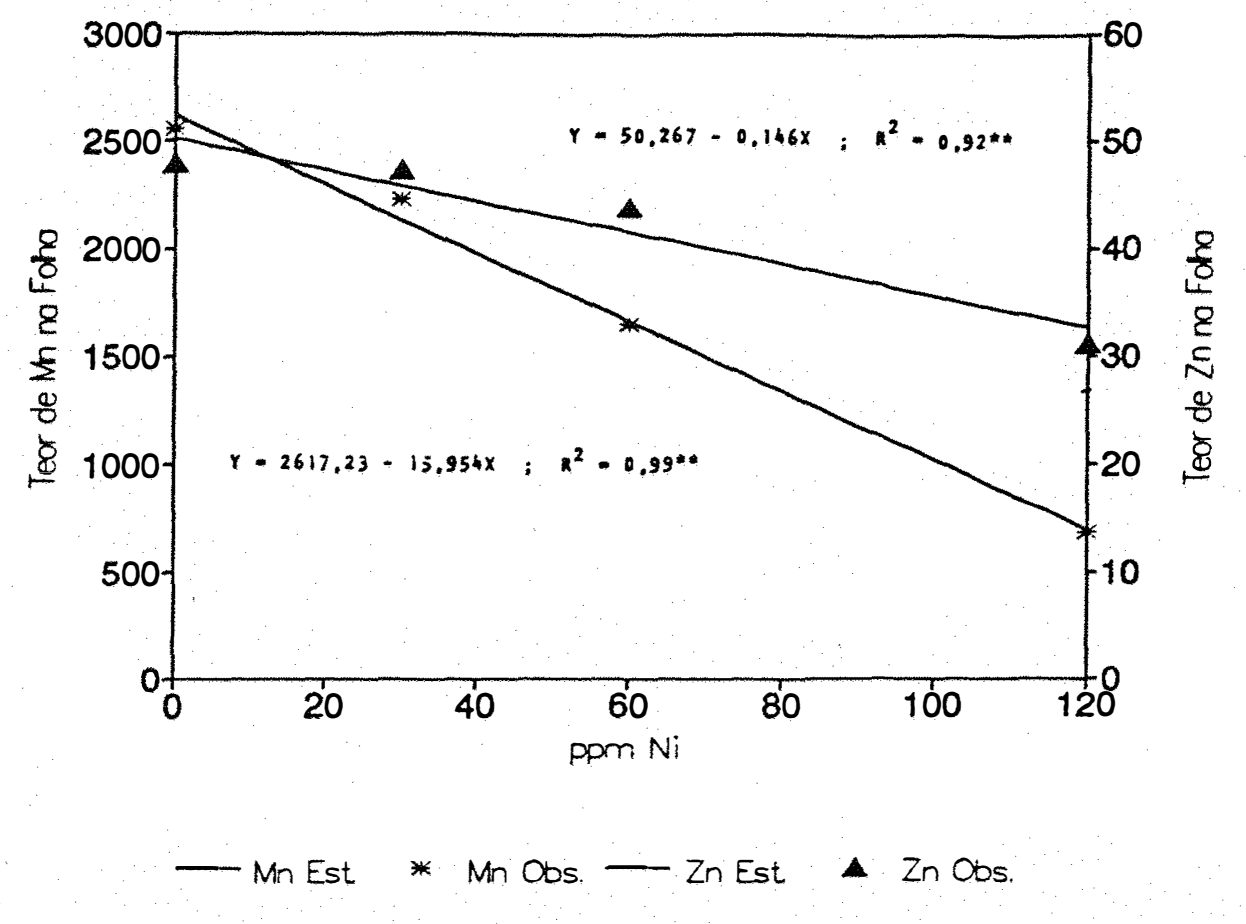

Figura 12. Relação entre teores de nutrientes (\% e ppm) nas folhas de arroz, e niveis de níquel (ppm) no solo 
menores. Estas diferenças foram notórias a partir do nível de 60ppm de $\mathrm{Ni}$. Nas equações de regressão, verificou-se efeitos lineares significativos $(\mathrm{P} \leq 0,01)$ dos teores de $\mathrm{Ni}$ em todas as partes da planta em relação às doses de $\mathrm{Ni}$, nos três solos.

4.2.2. Avaliação dos efeitos da calagem no controle da toxidez de $\mathrm{Ni}$ em dois solos ácidos

\subsubsection{Feijão}

Na Tabela 12, Figura 13 e Apêndice 22, estão apresentados os dados de produção de matéria seca de feijão, em decorrência da calagem e das doses de $\mathrm{Ni}$ em dois solos ācidos (LRd e TE). Verificouse, nas análises estatỉsticas, um efeito significativo da calagem no controle da toxidez de $\mathrm{Ni}$ no feijão, para ambos os solos. Estes efeitos negativos na produção de matéria seca, em função das doses crescentes de Ni, foram atenuados pela calagem dos solos. Desta forma, observa-se nos tratamentos que receberam calagem um efeito negativo linear $(P \leq 0,01)$ para o LRd, e um efeito quadrätico para a TE, em relação às doses de Ni. Enquanto que, nos tratamentos que não receberam aplicação de calcárịo, os efeitos foram quadräticos para o LRd e linear para a TE. Por outro lado, fazendo a análise dos efeitos da calagem, quando as plantas de feijão foram submetidas à maior dose de Ni (120ppm) verifica-se uma queda de $39 \%$ na produção de matéria seca total no solo LRd, e uma queda de $71 \%$ na TE, em relação aos tratamentos que receberam calagem e sem $\mathrm{Ni}(0 \mathrm{ppm})$. 
Tabela 12. Produção de matēria seca em feijão cuitivar Carioca, em função dos nỉveis de níquel e da calagem em dois solos äcidos ${ }^{1}$

Solos Calagem Ni Folha Raule + Raiz Casca Grão Total

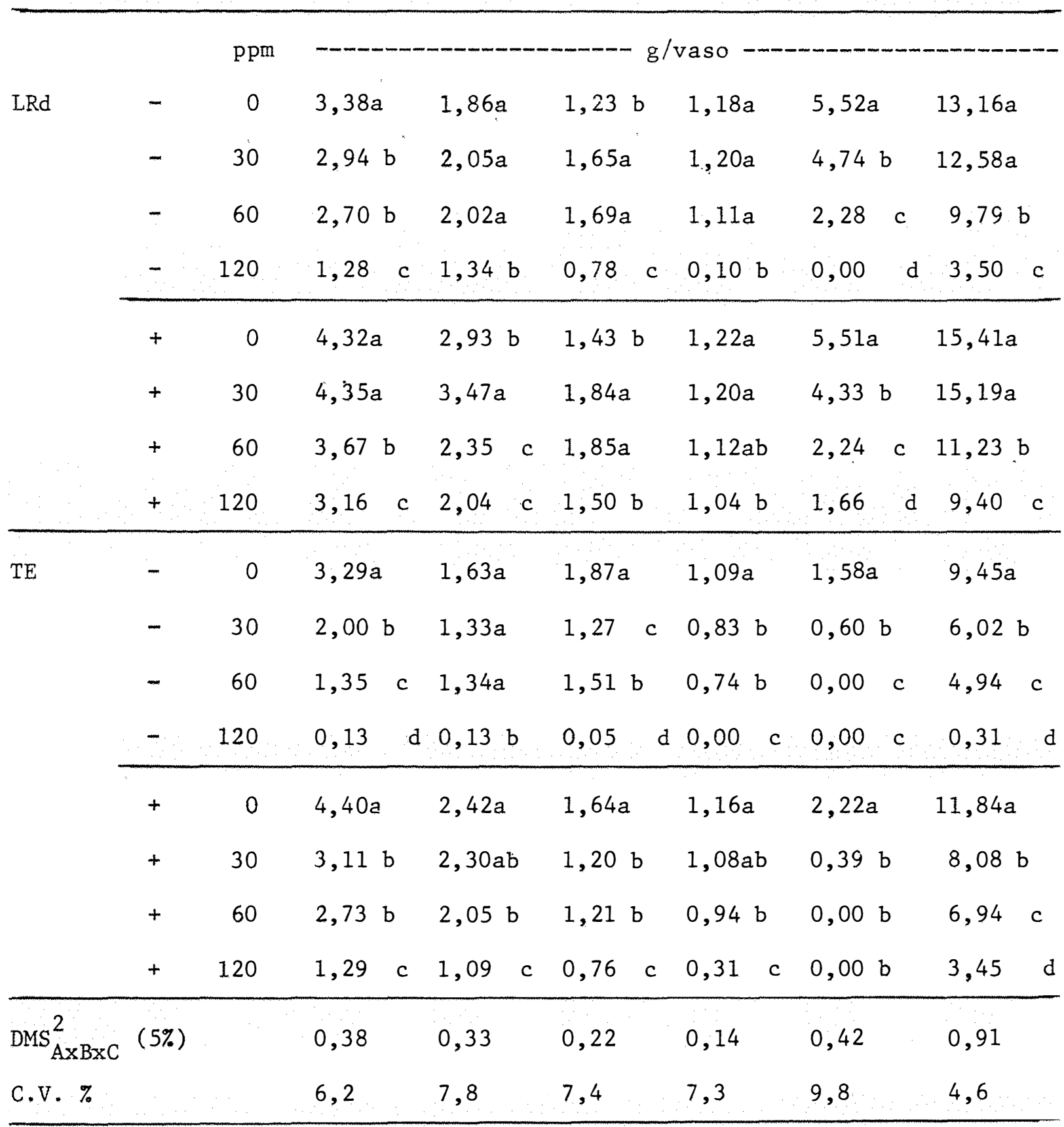

1 Mèdia de 3 repetições

2 Comparação de médias pelo teste de Tukey, da interação solos $x$ calagem $x$ níveis de $\mathrm{Ni}$. 


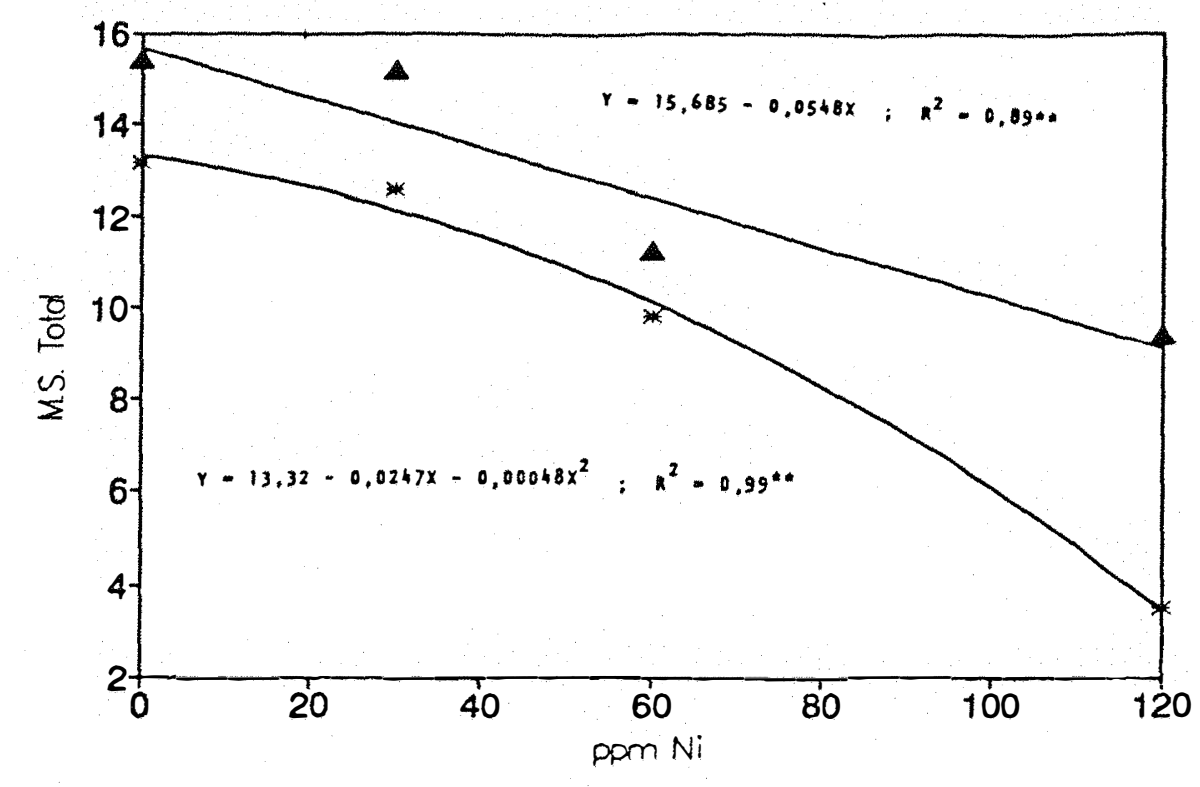

LRd

Sem Cal.Est * Sem Calobs. Com Cal.Est

- Com Cal Obs

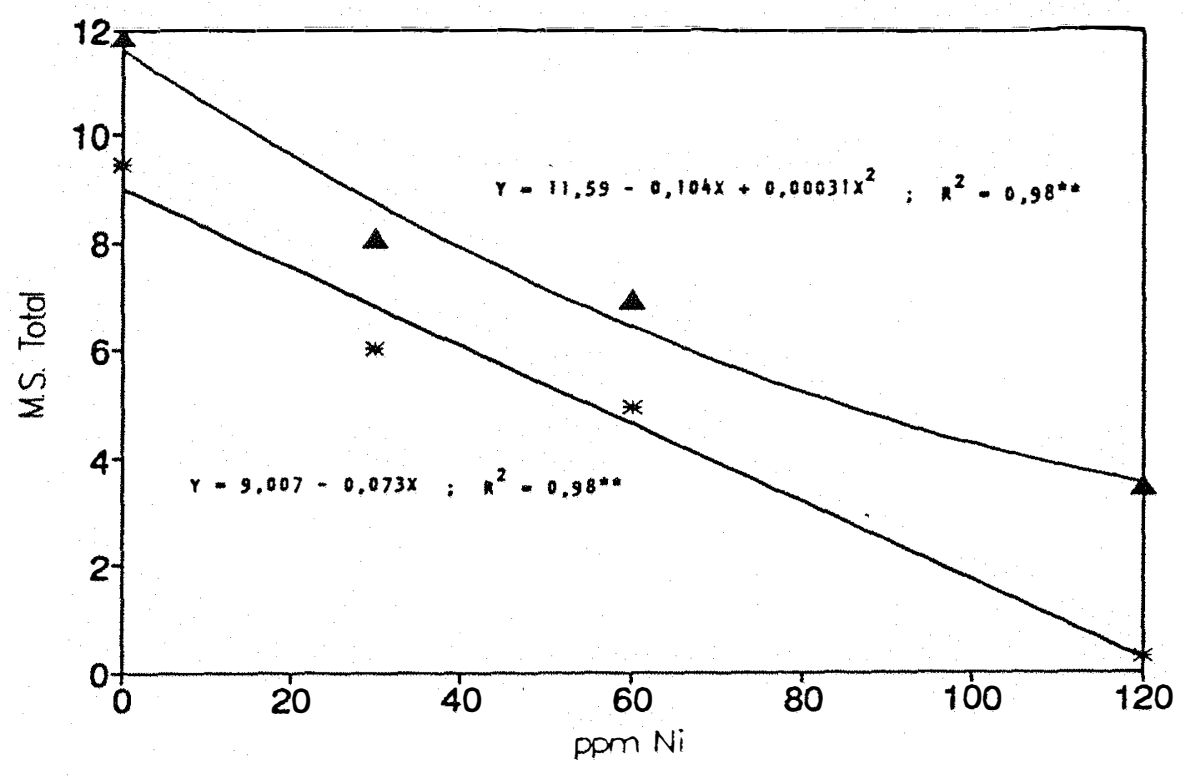

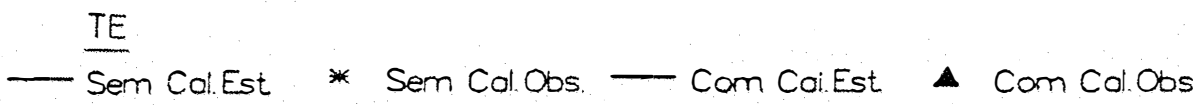

Figura 13. Relação entre a produção de matéria seca total (g/vaso) em feijoeiro, e níveis de níquel em dois solos ácidos (LRd e TE) com e sem calagem 
Em relação aos dados de teores de nutrientes e níquel na matéria seca do feijão (Tabela 13, Figura 14 e Apêndices 23, 24 e 25). Pode-se notar que a calagem ocasionou um aumento nos teores de $\mathrm{N}, \mathrm{P}$ e K. Os teores de $\mathrm{Fe}$, Mn e Ni diminuiram em todas as partes da planta pe la ação da calagem, enquanto que não foram afetados os teores de Ca, $\mathrm{Mg}, \mathrm{S}, \mathrm{Cu}$ e $\mathrm{Zn}$. As equações de regressão realizadas, mostram efeitos lineares e quadráticos significativos $(\mathrm{P} \leq 0,01)$ que provam a influência da calagem e das doses crescentes de $\mathrm{Ni}$ no teor de Mn na folha (Figura 13). Também a calagem afetou significativamente os teores de Ni em todas as partes da planta, diminuindo o seu teor, principalmente no LRd. O teor de Ni foliar diminui com a calagem, no solo submetido a doses crescentes de $\mathrm{Ni}(0,30,60$ e $120 \mathrm{ppm})$. As equações de regressão (Apêndice 23) entre o teor de $\mathrm{Ni}$ na matéria seca de feijoeiro e doses crescentes de $\mathrm{Ni}$ em dois solos äcidos (LRd e TE) com e semcalagem, apre sentaram correlações positivas $(P \leq 0,01)$ significativas.

\subsubsection{Arroz}

Na Tabela 14 e Apêndice 26, estão ilustrados os efeitos da calagem, em dois solos ácidos (LRd e TE) tratados com 4 doses de Ni $(0,30,60$ e 120ppm), sobre a produção de matéria seca de arroz. Nesta cultura os efeitos da calagem não foram estatisticamente significativos, enquanto que os efeitos das doses de $\mathrm{Ni}$ aplicadas ao solo foram significativas $(P \leq 0,01)$. Portanto, não foi possível observar os ef ei tos positivos da calagem no controle da toxidez de Ni em arroz. 
Tabela 13. Equações de regressão entre teores de nutrientes e níquel (\% e ppm) em feijoeiro (Y), e ppm de niquel (X) em dois solos ácidos com e sem calagem

\begin{tabular}{|c|c|c|c|c|c|c|}
\hline & \multicolumn{2}{|c|}{ Variävel } & \multicolumn{2}{|r|}{ Equação de Regressão } & \multirow[t]{2}{*}{$\mathrm{R}^{2}$} & \multirow[t]{2}{*}{$\mathbf{F}$} \\
\hline Parte & Nutriente & Calagem & Solos & & & \\
\hline \multirow[t]{4}{*}{ Folha } & $\mathbf{N}$ & $\begin{array}{l}- \\
+\end{array}$ & $\begin{array}{l}\text { LRd } \\
\text { TE } \\
\text { LRd } \\
\text { TE }\end{array}$ & $\begin{array}{l}Y=1,45+0,0104 X \\
Y=1,68+0,00345 X+0,00018 X^{2} \\
Y=2,37-0,0052 X+0,000038 X^{2} \\
Y=2,54-0,0131 X+0,00009 X^{2}\end{array}$ & $\begin{array}{l}0,99 \\
0,95 \\
0,28 \\
0,999\end{array}$ & $\begin{array}{c}\star \star \\
\star \\
\text { ns } \\
\text { ns }\end{array}$ \\
\hline & $\mathrm{K}$ & $\begin{array}{l}- \\
+\end{array}$ & $\begin{array}{l}\text { LRd } \\
\text { TE } \\
\text { LRd } \\
\text { TE }\end{array}$ & $\begin{array}{l}Y=2,32+0,0196 X \\
Y=2,23+0,0087 X \\
Y=4,76-0,0504 X+0,0003 X^{2} \\
Y=1,76+0,0103 X\end{array}$ & $\begin{array}{l}0,94 \\
0,69 \\
0,81 \\
0,93\end{array}$ & $\begin{array}{l}\star \star \\
\star \\
\star \star \\
\star \star\end{array}$ \\
\hline & M8 & $\begin{array}{l}- \\
+\end{array}$ & $\begin{array}{l}\text { LRd } \\
\text { TE } \\
\text { LRd } \\
\text { TE }\end{array}$ & $\begin{array}{l}Y=0,96-0,0011 X+0,000012 X^{2} \\
Y=1,31+0,00069 X-0,00001 X^{2} \\
Y=1,04-0,0057 X+0,000036 X^{2} \\
Y=1,00+0,0021 X-0,00001 X^{2}\end{array}$ & $\begin{array}{l}0,78 \\
0,37 \\
0,999 \\
0,63\end{array}$ & $\begin{array}{l}\text { ns } \\
\text { ns } \\
\star \star \\
\text { ns }\end{array}$ \\
\hline & $\mathrm{Mn}$ & + & $\begin{array}{l}\text { LRd } \\
\text { TE } \\
\text { LRd } \\
\text { TE }\end{array}$ & $\begin{array}{l}Y=515,4-1,115 X \\
Y=1532,22-23,307 X+0,094 X^{2} \\
Y=151,58-0,381 X+0,00165 X^{2} \\
Y=269,9-1,434 X\end{array}$ & $\begin{array}{l}0,79 \\
0,95 \\
0,86 \\
0,97\end{array}$ & $\begin{array}{c}\star \\
\star \star \\
\text { ns } \\
\star\end{array}$ \\
\hline \multirow[t]{4}{*}{$\begin{array}{l}\text { Caule + } \\
\text { Kamo }\end{array}$} & Mg & + & $\begin{array}{l}\text { LRd } \\
\text { TE } \\
\text { LRd } \\
\text { TE }\end{array}$ & $\begin{aligned} Y & =0,808+0,0012 X-0,000005 X^{2} \\
Y & =0,803+0,004 X \\
Y & =0,855-0,0015 X+0,000012 X^{2} \\
Y & =1,065-0,0021 X\end{aligned}$ & $\begin{array}{l}0,43 \\
0,96 \\
0,87 \\
0,89\end{array}$ & $\begin{array}{l}\text { ns } \\
\star \star \\
\text { ns } \\
\star \star\end{array}$ \\
\hline & $\mathrm{Fe}$ & $\begin{array}{l}- \\
+\end{array}$ & $\begin{array}{l}\text { LRd } \\
\text { TE } \\
\text { LRd } \\
\text { TE }\end{array}$ & $\begin{array}{l}Y=279,54-0,611 X-0,0026 X^{2} \\
Y=258,13-3,554 X+0,068 X^{2} \\
Y=299,44-1,337 X+0,007 X^{2} \\
Y=255,5+2,467 X\end{array}$ & $\begin{array}{l}0,94 \\
0,91 \\
0,38 \\
0,92\end{array}$ & $\begin{array}{c}\text { ns } \\
\text { * } \\
\text { ns } \\
\star\end{array}$ \\
\hline & Mn & $\begin{array}{l}- \\
+\end{array}$ & $\begin{array}{l}\text { LRd } \\
\text { TE } \\
\text { LRd } \\
\text { TE }\end{array}$ & $\begin{array}{l}Y=76,75-1,077 X+0,0058 X^{2} \\
Y=427,30-3,549 X \\
Y=39,34-0,096 x+0,0003 X^{2} \\
Y=68,60-0,28 X\end{array}$ & $\begin{array}{l}0,99 \\
0,70 \\
0,33 \\
0,99\end{array}$ & $\begin{array}{l}\text { ns } \\
\star \star \\
\text { ns } \\
\text { ns }\end{array}$ \\
\hline & $\mathrm{Ni}$ & $\begin{array}{l}- \\
+\end{array}$ & $\begin{array}{l}\text { LRd } \\
\text { TE } \\
\text { LRd } \\
\text { TE }\end{array}$ & $\begin{array}{l}Y=40,10+1,527 X \\
Y=33,93+1,324 X+0,0326 X^{2} \\
Y=30,90+1,19 X \\
Y=10,92+2,621 X-0,0087 X^{2}\end{array}$ & $\begin{array}{l}0,98 \\
0,98 \\
0,95 \\
1,00\end{array}$ & $\begin{array}{c}\star \star \\
\star \star \\
\star \star \\
\star\end{array}$ \\
\hline \multirow[t]{4}{*}{ Raiz } & $\mathrm{k}$ & $\begin{array}{l}- \\
+\end{array}$ & $\begin{array}{l}\text { LRd } \\
\text { TE } \\
\text { LRd } \\
T E\end{array}$ & $\begin{array}{l}Y=-0,04+0,0065 X \\
Y=0,081+0,0108 X-0,00006 X^{2} \\
Y=0,303+0,0018 X-0,000015 X^{2} \\
Y=0,357-0,0068 X+0,000087 X^{2}\end{array}$ & $\begin{array}{l}0,82 \\
0,96 \\
0,96 \\
0,997\end{array}$ & $\begin{array}{l}\star \star \\
\star \star \\
\text { ns } \\
\star \star\end{array}$ \\
\hline & $\mathrm{Ca}$ & $\begin{array}{l}- \\
+\end{array}$ & $\begin{array}{l}\text { LRd } \\
\text { TE } \\
\text { LRd } \\
\text { TE }\end{array}$ & $\begin{array}{l}Y=0,866+0,0032 X-0,000015 X^{2} \\
Y=1,048-0,0051 X+0,000032 X^{2} \\
Y=1,413-0,0006 X+0,0000013 X^{2} \\
Y=0,916-0,00011 X+0,0000009 X^{2}\end{array}$ & $\begin{array}{l}0,51 \\
0,96 \\
0,11 \\
0,05\end{array}$ & $\begin{array}{l}\text { ns } \\
\text { ns } \\
\text { ns } \\
\text { ns }\end{array}$ \\
\hline & $2 n$ & $\begin{array}{l}- \\
+\end{array}$ & $\begin{array}{l}\text { LRd } \\
\text { TE } \\
\text { LRd } \\
\text { TE }\end{array}$ & $\begin{array}{l}Y=80,54-1,436 X+0,0099 X^{2} \\
Y=57,43-1,025 X+0,0115 X^{2} \\
Y=41,76-0,124 X+0,00048 X^{2} \\
Y=42,02-0,285 X+0,0013 X^{2}\end{array}$ & $\begin{array}{l}0,85 \\
0,998 \\
0,83 \\
0,65\end{array}$ & $\begin{array}{l}\star \star \\
\star \star \\
\text { ns } \\
\text { ns }\end{array}$ \\
\hline & $\mathrm{Ni}$ & $\begin{array}{l}- \\
+\end{array}$ & $\begin{array}{l}\text { LRd } \\
\text { TE } \\
\text { LRd } \\
\text { TE }\end{array}$ & $\begin{array}{l}Y=40,58+0,77 X+0,032 X^{2} \\
Y=56,91+0,745 X+0,0798 X^{2} \\
Y=19,60+2,984 X \\
Y=23,50+3,005 X\end{array}$ & $\begin{array}{l}0,996 \\
0,997 \\
0,99 \\
0,98\end{array}$ & $\begin{array}{l}\star \star \\
\star \star \\
\star \star \\
\star \star\end{array}$ \\
\hline
\end{tabular}

** Significativo ao nível de $1 \%$

* Significativo ao nível de 5\%

ns Não significativo 

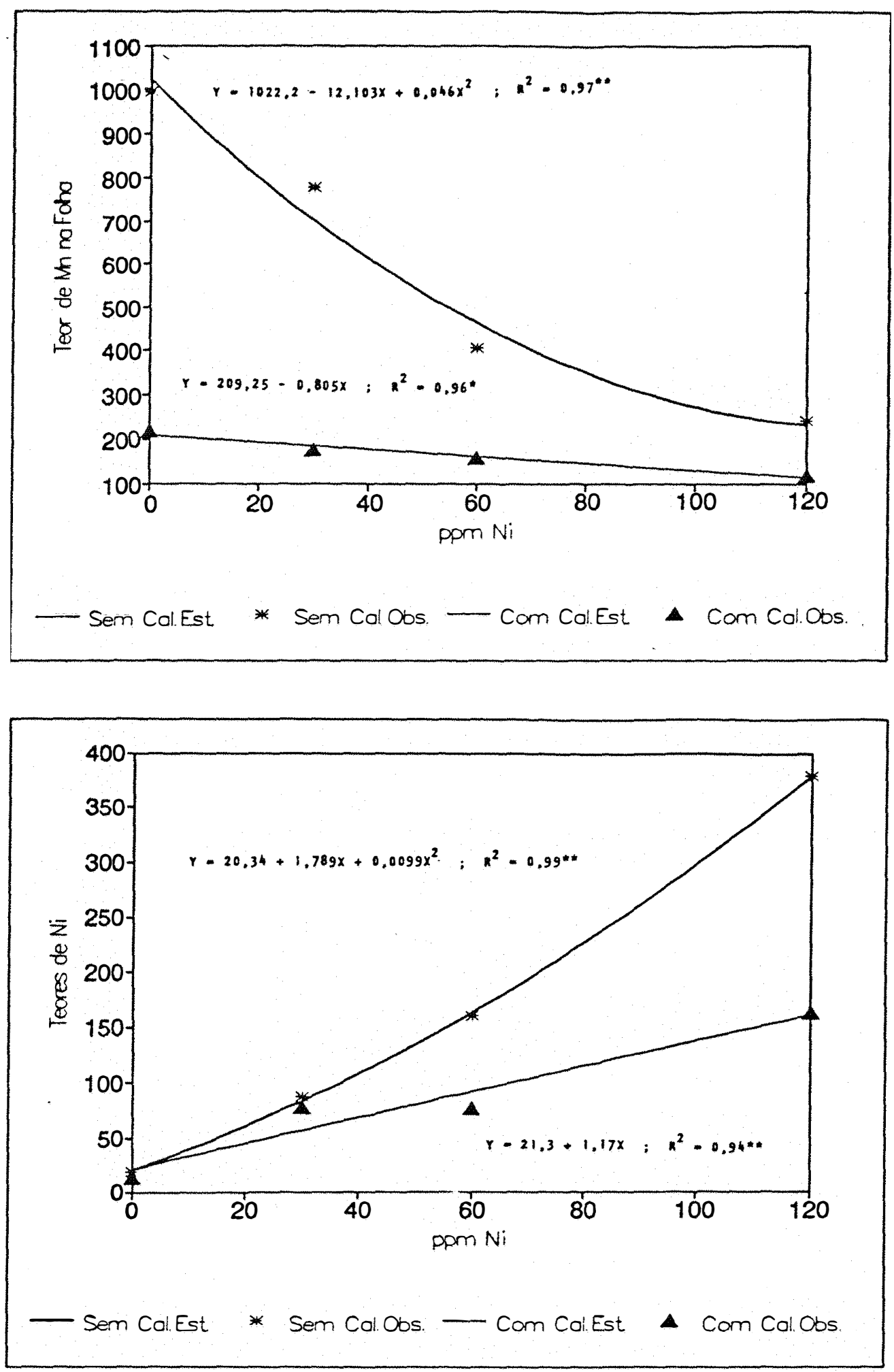

Figura 14. Relação entre teores de $\mathrm{Mn}$ e $\mathrm{Ni}$ (ppm) nas folhas de feijoeiro, e niveis de níquel no solo com e sem calagem 
Tabela 14. Produção de matēria seca em arroz variedade IAC-165, em função dos niveis de níquel e da calagem em dois solos ácidos ${ }^{1}$

Solos Calagem Ni Folha Polmo + Rerfiho Raiz Raquis Grão Total

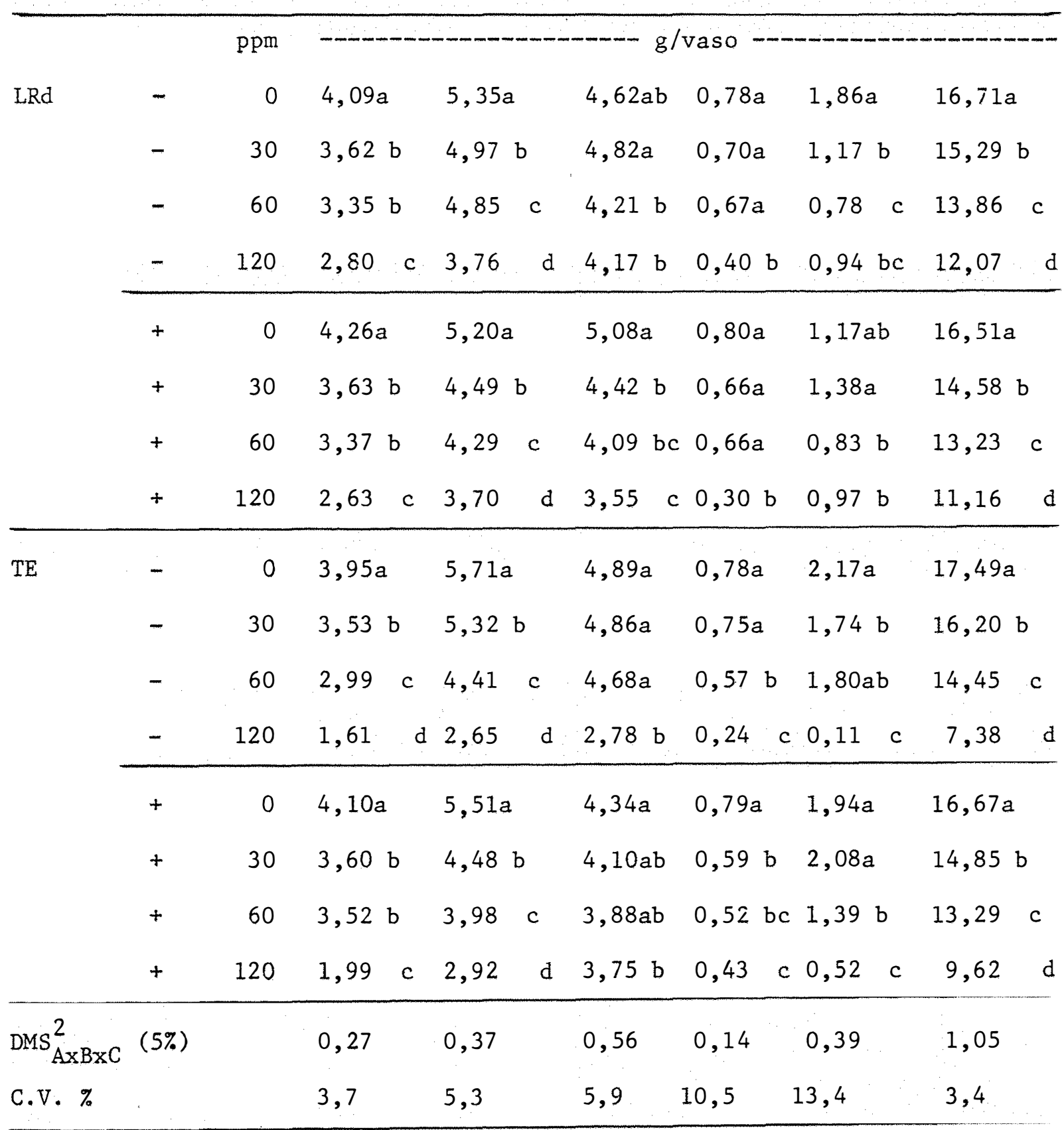

1 Mẻdia de 3 repetições

2 Comparação de médias pelo teste de Tukey, da interação solos $x$ calagem $x$ niveis de $\mathrm{Ni}$ 
Por outro lado, observou-se nas análises dos teores de nutrientes e níquel (Tabela 15 e Apêndices 27, 28 e 29) de todas as par tes da planta, um efeito positivo da calagem na assimilação de $P$, Ca e Mg, além de permitir uma diminuição nos elevados teores de Mn na plan ta. Também a calagem dos.solos não afetou os teores de $\mathrm{Ni}$ e Fe nas diversas partes da planta. Os teores foliares de Mn, em plantas de arroz crescidas em solos com adições de doses crescentes de Ni (Figura 15), diminuiram com a calagem do solo e com a aplicação de doses crescentes de $\mathrm{Ni}(0,30,60$ e $120 \mathrm{ppm})$. As equações de regressão (Apêndice 27) entre os teores de $\mathrm{Ni}$ na matéria seca de arroz e doses crescentes de $\mathrm{Ni}$ em dois solos ácidos (LRd e TE) com e sem calagem, apresentaram correlações positivas $(\mathrm{P} \leq 0,01)$ significativas.

4.2.3. Ni-solūvel em DTPA-TEA em solos ácidos com e sem calagem

No Apêndice 30, apresentam-se os teores de Ni-solúvel em DTPA-TEA em três solos ácidos ( $V$, LRd e TE), tratados com 4 doses de Ni (0, 30, 60 e 120ppm), e com aplicação de calcário nos solos LRd e TE. Verifica-se que os teores de Ni-solüvel foram maiores no Vertissolo, em comparação com o LRd e a TE. Tambëm, observa-se que as doses crescentes de $\mathrm{Ni}$ provocam uma elevação nos teores de Ni-solūvel nos três solos. A calagem dos solos (LRd e TE) induz diminuições significativas nos teores de Ni-solúvel em relação aos solos que não receberam calagem. 
Tabela 15. Equações de regressão entre teores de nutrientes e níquel (\% e ppm) em arroz (Y), e ppm de níquel (X) em dois solos äcidos com e sem calagem

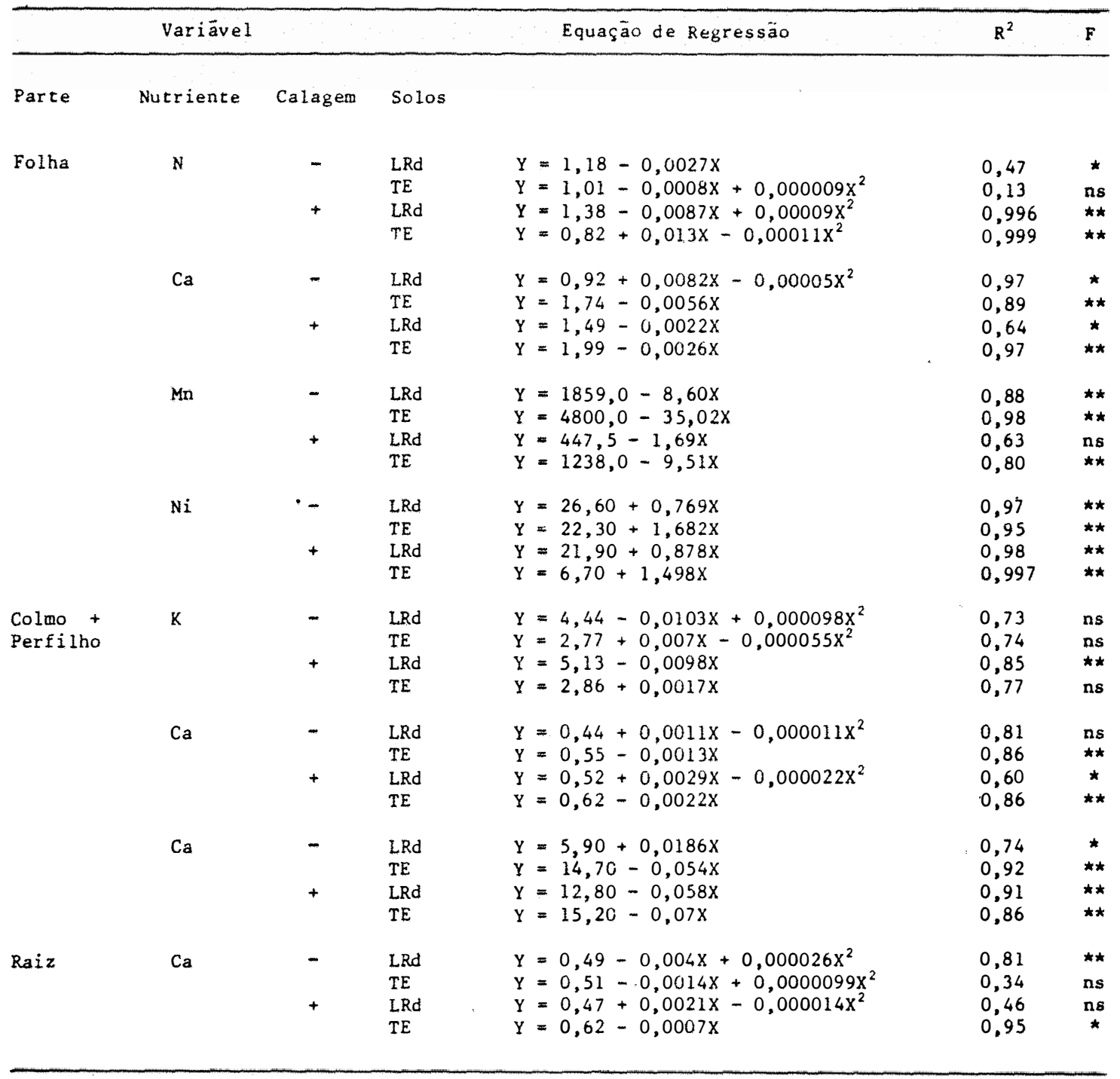

** Significativo ao nivel de $1 \%$

* Significativo ao nivel de $5 \%$

ns Não significativo 


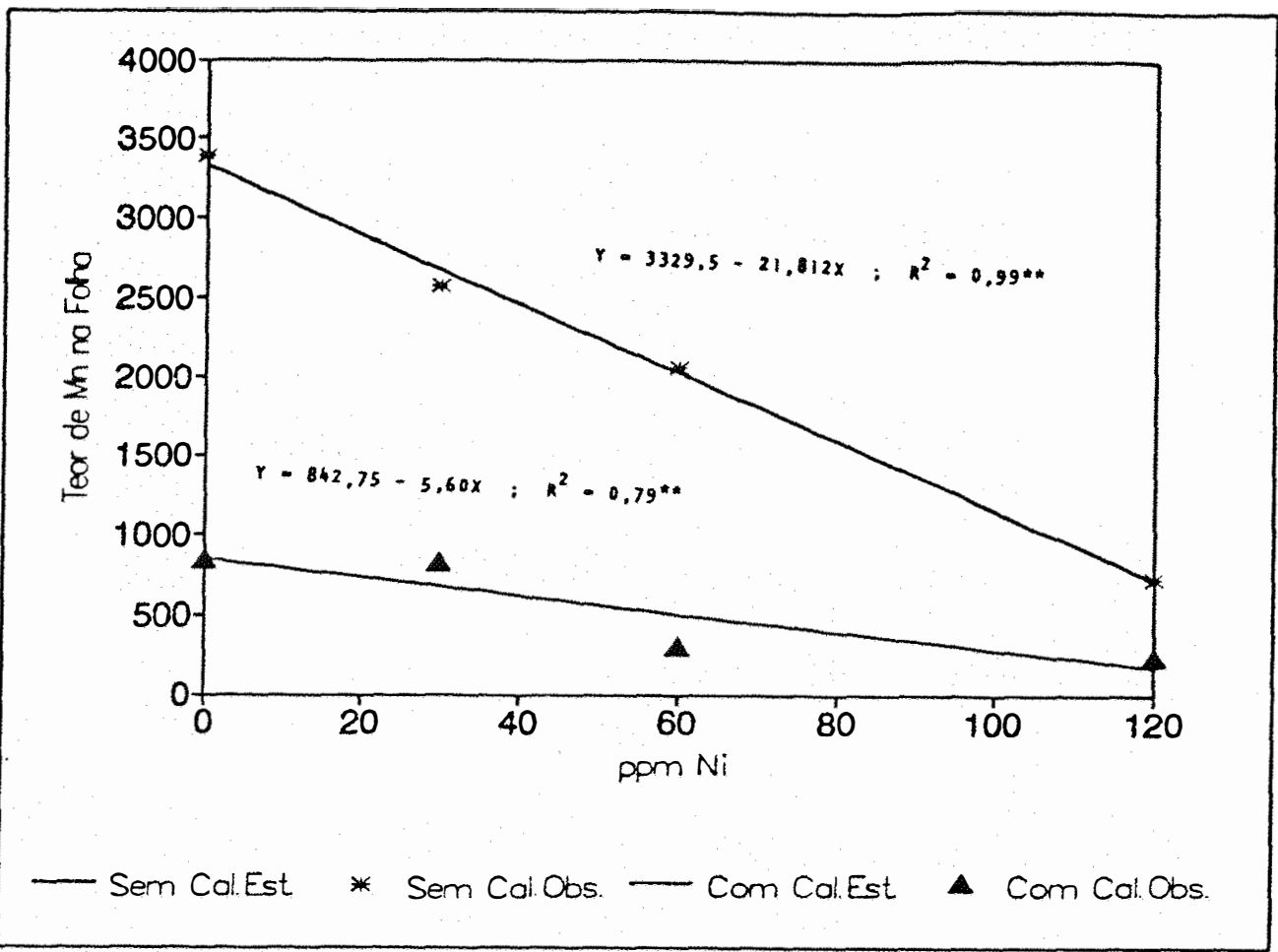

Figura 15. Relação entre teores de Mn (ppm) nas folhas de arroz, e niveis de niquel no solo com e sem calagem

Encontram-se nas Tabelas 16 e 17 , as correlações $(P \leq 0,05)$ entre a produção de matëria seca total de arroz e feijão e os teores de Ni-solúvel em DTPA-TEA em três solos ácidos (V, LRd e TE) e emi dois solos que receberam calagem (LRd e TE). Existem correlações significativas $(P \leq 0,05)$, com altos coeficientes de determinação $(0,95-1,00)$, que demonstram um ef eito direto dos teores de Ni-solüvel em DTPA-TEA so bre a produção de matéria seca nas duas culturas (arroz e feijão). Esta correlação foi negativa linear nos solos LRd e TE, enquanto que no Vertissolo este efeito foi quadrático. 
Tabela 16. Equações de regressão entre a produção de matéria seca total (g/vaso) nas culturas de arroz e feijão (Y), e $\mu \mathrm{g} / \mathrm{ml}$ de Ni-solūvel em DTPA-TEA (X) em três solos äcidos

\begin{tabular}{|c|c|c|c|c|}
\hline \multicolumn{2}{|c|}{ Variāvel } & \multirow[t]{2}{*}{ Equação de Regressão } & \multirow[t]{2}{*}{$\mathrm{R}^{2}$} & \multirow[t]{2}{*}{$\mathrm{F}$} \\
\hline Solos & Cultura & & & \\
\hline \multirow[t]{2}{*}{ V } & Feijão & $Y=21,862+0,35 X-0,0107 X^{2}$ & 0,96 & $\mathrm{~ns}$ \\
\hline & Arroz & $Y=36,175-0,889 X+0,0133 X^{2}$ & 0,999 & * \\
\hline \multirow[t]{2}{*}{ LRd } & Feijão & $Y=14,101-0,3655 X$ & 0,95 & * \\
\hline & Arroz & $Y=16,467-0,167 X$ & 0,99 & $*$ \\
\hline \multirow[t]{2}{*}{$\mathrm{TE}$} & Feijão & $Y=8,781-0,349 X$ & 0,95 & ns \\
\hline & $\operatorname{Arroz}$ & $Y=18,175-0,416 X$ & 0,95 & $\star$ \\
\hline
\end{tabular}

Tabela 17. Equações de regressão entre a produção de matéria seca total (g/vaso) nas culturas de arroz e feijão (Y), e $\mu g / m l$ de Ni-solūvel em DTPA-TEA (X) em dois solos ācidos com e sem calagem

\begin{tabular}{|c|c|c|c|c|c|}
\hline \multicolumn{3}{|c|}{ Variável } & \multirow[t]{2}{*}{ Equação de Regressão } & \multirow[t]{2}{*}{$\mathrm{R}^{2}$} & \multirow[t]{2}{*}{$\mathrm{F}$} \\
\hline Solos & Calagem & Cultura & & & \\
\hline \multirow[t]{4}{*}{ LRd } & - & Feijão & $Y=14,101-0,3655 X$ & 0,95 & * \\
\hline & & Arroz & $Y=16,467-0,167 X$ & 0,99 & $*$ \\
\hline & + & Feijão & $Y=15,51-0,293 X$ & 0,86 & ns \\
\hline & & Arroz & $Y=16,512-0,416 X+0,00786 X^{2}$ & 1,00 & $*$ \\
\hline \multirow[t]{4}{*}{$\mathrm{TE}$} & - & Feijão & $Y=8,781-0,349 X$ & 0,95 & ns \\
\hline & & Arroz & $Y=18,175-0,416 X$ & 0,95 & * \\
\hline & + & Feijão & $Y=10,624-0,365 X$ & 0,91 & $\mathrm{~ns}$ \\
\hline & & $\operatorname{Arroz}$ & $Y=16,364-0,33 X$ & 0,99 & * \\
\hline
\end{tabular}

* Significativo ao nivel de $5 \%$

ns Não significativo 
Nos solos com calagem (LRd e TE), não houve correlações significativas $(P \leq 0,05)$ entre a produção de matéria seca total de feijão e os teores de Ni-solúvel em DTPA-TEA. Por outro lado, existiram cor relações negativas significativas entre a produção de matéria seca total de arroz e os teores de Ni-solúvel em DTPA-TEA, sendo que, na presença de calcārio as equações de regressão ajustaram-se melhor. 
5. DISCUSSÃO

5.1. Ensaios em solução nutritiva

5.1.1. Produção de matéria seca

Os resultados obtidos com relação aos éfeitos do $\mathrm{Ni}$ sobre a produção de matéria seca nas culturas de feijão e arroz, mostram notórias reduções por ação das doses crescentes de $\mathrm{Ni}$.

No feijoeiro, os efeitos da toxidez de $\mathrm{Ni}$ expressaram-se nos tratamentos com 2 e $4 \mathrm{ppm}$ de $\mathrm{Ni}$ na solução nutritiva, reduzindo a produção de matéria seca total em 38 e 85\%, respectivamente, em relação a testemunha (sem $\mathrm{Ni}$ ). Estes resultados foram semelhantes aos reportados por WALLACE et alii (1977a) que verificaram uma redução de $78 \%$ na produção de matëria seca total de feijão cultivar Improved Tendergreen por ação de $2,94 \mathrm{ppm}$ de $\mathrm{Ni}$ na solução nutritiva. RAUSER \& SAMARAKOON (1980), sugerem que o níquel poderia inibir a exportação de produtos da fotossintese das folhas unifoliadas para regiões deficientes na plan ta, sendo que néstas folhas acumulam-se quantidades crescentes de 
sacarose, amido e açúcares redutores, ocasionando a redução no crescimento das plantas.

Existem diferenças no grau de tolerância à toxidez de $\mathrm{Ni}$ entre os dois cultivares de feijão utilizados (Carioca e IAPAR-14). As anālises estatísticas realizadas mostram que o cultivar IAPAR-14 é mais tolerante, conforme mostraram os efeitos das doses crescentes de Ni na produção de matéria seca. No cultivar IAPAR-14 estas reduções fo ram menores, em comparação ao cultivar Carioca.

Os efeitos das doses crescentes de $\mathrm{Ni}$ em arroz foram evi dentes com concentrações mais elevadas de $\mathrm{Ni}$ na solução nutritiva. As doses de 4, 8 e 12ppm reduzìram a produção de matēria seca total em 6, 39 e 64\%, respectivamente, em relação aos tratamentos sem Ni. WALLACE et alii (1977b) encontraram em arroz, cultivar Earlirose, que 6ppm de $\mathrm{Ni}$ na solução nutritiva reduzem a produção de matéria seca em $35 \%$.

As variedades de arroz IAC-165 e IAC-4440, também apresentam ligeiras evidências que demonstram uma diferença na sua tolerância à toxidez de Ni. As análises de regressão dos efeitos das doses de Ni sobre a produção de matéria seca, constatam que a variedade IAC-165 é um pouco mais tolerante.

As diferenças encontradas entre as culturas de feijão e arroz, em relação às doses crescentes de Ni, demonstram um comportamento diferente entre as espécies de plantas, sendo que o arroz resultou mais tolerante à toxidez de Ni do que o feijão. Em outras espécies de plantas, a produção de matéria seca se reduz significativamente, em soluções nutritivas com teores de $\mathrm{Ni}$ de: 1ppm em mudas de café (PAVAN \& 
BINGHAM, 1982), 5ppm em aveia (HUNTER \& VERGNANO, 1953), 6ppm em algodão (REHAB \& WALLACE, 1978), e 10ppm em plântulas de espécies florestais (LOZANO \& MORRISON, 1982). Também existem diferenças entre variedades e cultivares da mesma espécie.

De acordo com BARCELō \& POSCHENRIEDER (1990) os possíveis mecanismos envolvidos na tolerância à toxidez de $\mathrm{Ni}$ foram a compartimentação do elemento no vacúolo das células e acumulação no apoplasma (espaços intercelulares e parede celular), na forma de metalotioninas ou fitoquelatinas. Espécies de plantas acumuladoras de Ni, tem a capacidade de acumular $\mathrm{Ni}$ na sua seiva (FOY et alii, 1978). No entanto, a ausência de metodologias confiāveis e sensíveis tem impedido o progresso na identificação de outros mecanismos de tolerância.

\subsubsection{Teor de nutrientes e níquel em feijão e arroz}

\subsubsection{Teor de nutrientes}

Nos resultados obtidos para feijoeiro, observa-se que o níquel exerce influências variáveis na concentração e distribuição de N, P, K, Ca, Mg, S, B, Cu, Fe, Mn e Zn. Na presença de altas doses de $\mathrm{Ni}$ na solução nutritiva aumentaram os teores de N, P, K, B, Cu, Mn e $\mathrm{Zn}$ na matéria seca do feijão. Por outro lado, os teores foliares de Mg e Fe diminuiram, enquanto que os teores de Ca e $S$ não foram significativamente afetados. 0 aumento nos teores dos nutrientes, em relação aos níveis crescentes de $\mathrm{Ni}$, pode ser explicado pelo efeito concentração, devido à menor produção de matéria seca. 
Analisando os teores de nutrientes nas folhas de feijão, verifica-se a existência de interações entre o $\mathrm{Ni}$ e o Fe e Mg. Também nota-se que os teores de Fe na raiz aumentam significativamente conforme aumentam as doses de $\mathrm{Ni}$ na solução nutritiva. Esta resposta foi verificada por CHINO \& MITSUI (1967), que explicam que o Ni pode inibir a absorção e translocação de Fe pelas plantas. FOY et alii (1978) confirmam que o $\mathrm{Ni}$ pode causar deficiência de ferro inibindo sua translocação das raízes a parte aérea. CKOOKE \& KNIGHT (1955) encontraram que os teores de ferro no tecido necrosado de plantas,que sofrem toxidez de $\mathrm{Ni}$, foram muito baixos.

As interações do $\mathrm{Ni}$ com $\circ \mathrm{Mg}$, provavelmente, devem-se a efeitos diretos e indiretos. ANDERSON et alii (1973) verificam uma ação direta do $\mathrm{Ca}^{2+}, \mathrm{Mg}^{2+}, \mathrm{Fe}^{2+}$ e $\mathrm{Zn}^{2+}$ que inibem a absorção e translocação do $\mathrm{Ni}$ na maioria das espécies de plantas. Também as altas doses de $\mathrm{Ni}$ podem indiretamente diminuir a absorção e translocação de $\mathrm{Mg}$, favorecendo uma maior assimilação de $\mathrm{K}$ nas plantas; $\mathrm{O} \mathrm{K}^{+}$inibe competitivamente a absorção de $\mathrm{Mg}^{2+}$ (MALAVOLTA, 1980).

Em relação à influência de altas doses de $\mathrm{Ni}$ nos teores de nutrientes em arroz, observa-se um aumento nos teores de N, P, K, B e $\mathrm{Cu}$. Os teores de $\mathrm{Ca}, \mathrm{Mg}$ e Mn diminuiram, enquanto que não foram afetados significativamente os teores de $\mathrm{S}$, Fe e $\mathrm{Zn}$. As interações geradas pelo $\mathrm{Ni}$ expressaram-se claramente com os teores foliares de $\mathrm{Ca}, \mathrm{Mg}$ e Mn. Entretanto, os teores de Fe na matéria seca de arroz sofreram ligeiros aumentos com as doses de $\mathrm{Ni}$, não significando uma maior disponibilidade do nutriente ( $\mathrm{Fe}$ ); provavelmente, esse elemento está formando parte de compostos metabolicamente não ativos. CROOKE 
verificara que a deficiência induzida de Fe por metais, foi causada por indisponibilidade de Fe nos tecidos, e não esteve relacionada com o teor de Fe-total da planta. Por outro lado, observa-se que os teores de $\mathrm{Fe}$ na raiz foram maiores aos obtidos nas outras partes da planta. Aparentemente, o Ni interfere na absorção de Fe e inibe o seu metabolismo (AGARWALA et alii, 1977).

Existe um efeito antagônico do níquel em relação à absorção e transporte de manganês na planta, este efeito poderia ter sido incrementado pelos altos teores de ferro na matéria seca do arroz. MISRA \& DWIVEDI (1977) constataram este comportamento na cultura de milho. Em aveia, WILLIAMS (1967) mostra que o $\mathrm{Ni}$ e o Mn atuam em conjunto, aumentando a taxa de assimilação de ferro pela planta e inibindo sua participação nos processos metabólicos. Desta forma, além da interação Nix Mn, existe a interação MnxFe. SIDERIS \& YOUNG (1949) constataram que o Mn substitui ao Fe nos precursores da síntese de clorofila.

Também, as altas doses de Ni diminuem a assimilação de Ca e Mg, provavelmente, devido a processos de inibição competitiva na absor ção de Ca e Mg. CHAMEL \& NEUMANN (1987) observaram em muitas espécies de plantas que $\circ \mathrm{Ni}^{2+}$ inibe competitivamente a absorção de $\mathrm{Ca}^{2+}, \mathrm{Mg}^{2+}, \mathrm{Fe}^{2+}$ e $\mathrm{Zn}^{2+}$.

5.1.2.2. Teor de níque1

O teor de $\mathrm{Ni}$ na matéria seca de plantas de arroz e feijão aumenta em função das doses crescentes de Ni na solução nutritiva. Nas partes da planta de feijão, os teores variam na seguinte ordem: raiz>cau le + ramo $>$ casca $\simeq$ grão $>$ folha. No arroz, a sequência foi: 
raiz $>$ colmo + perfilho $\simeq$ folha $>$ raquis $\simeq$ grão. Portanto, a acumulação de $\mathrm{Ni}$ ocorre principalmente na raiz. WALLACE et alii (1977c) e VANSELOW (1965), verificaram que os metais pesados geralmente acumulam-se nas raízes das plantas. CATALDO et alii (1978) demonstraram que o Ni-disponíve1 foi rapidamente absorvido pelas raízes de soja.

Os teores de $\mathrm{Ni}$ nas folhas das duas culturas permitem estabelecer uma maior tolerāncia à toxidez de Ni do arroz, em relação ao fei jão. Conforme observa-se, teores foliares acima de 40ppm não afetaram a produção de matéria seca no arroz, enquanto que no feijão a produção se reduz significativamente. Teores foliares de até 140ppm de Ni não afetaram significativamente a produção de matéria seca nas duas coletas de arroz. Nas duas culturas, existem correlações positivas significativas $(\mathrm{P} \leq 0,01)$ entre as doses de $\mathrm{Ni}$ e seu teor nas folhas.

\subsubsection{Teor de clorofila total nas folhas}

Existe um efeito negativo das altas doses de $\mathrm{Ni}$ nos teores de clorofila total em folhas de feijão e arroz. No feijoeiro, estes efeitos negativos expressaram-se em doses de $\mathrm{Ni}$ superiores a $2 \mathrm{ppm}$, enquanto que, no arroz, estes efeitos apresentaram-se em todos os níveis de $\mathrm{Ni}(4,8$ e 12ppm). Estes efeitos, provavelmente, se devem à menor absorção de Mg pelas plantas ocasionadas pelas altas doses de Ni na solução nutritiva, afetando a estrutura dos pigmentos fotossintéticos.

Tambëm foram observadas correlações significativas entre o teor de clorofila total e o teor de $\mathrm{Ni}$ em folhas de feijão, coletadas por ocasião da floração. No arroz, estas correlações não foram significativas. Assim a reduzida concentração de clorofila total nas folhas foi 
associada com cloroses do tecido e teores de $\mathrm{Ni}$ nas folhas de 40ppm no feijão, e de 200ppm no arroz. PAVAN \& BINGHAM (1982) encontraram que as altas doses de $\mathrm{Ni}$ em solução nutritiva diminuiram significativamente o teor de clorofila total nas folhas de café.

Os excessos de níquel interferem na função estomática em feijão, portanto também afetam os processos de respiração, transpiração e fotossintese das plantas. RAUSER \& DUMBROFF (1981) verificaram que plantas de feijão expostas por curtos perîodos ( 2 dias) a altas con centrações de $\mathrm{Ni}$, incrementaram sua resistência estomatar e seu nível de ácido abscísico na folha, provocando o fechamento dos estômatos, devido provavelmente a alterações no fluxo de $\mathrm{K}^{+}$atravēs da membrana ou afetando o sistema energético. SHEORAN et alii (1990) encontraram que plantas de Cajanus cajan L. submetidas a altas doses de $\mathrm{Ni}^{2^{+}}$. reduziram sua taxa de fotossíntese, devido aos efeitos do $\mathrm{Ni}$ sobre o sistema de transporte de elétrons e a resistência estomatar. A atividade das enzimas que participam no ciclo redutivo do carbono não foram significativamente afetadas.

5.1.3. Estudos preliminares dos efeitos da toxidez de $\mathrm{Ni}$ nas folhas de arroz e feijão, a nỉvel ultraestrutural

Os efeitos das altas doses de $\mathrm{Ni}$ nas ultraestruturas celulares de folhas de arroz e feijão ocorreram principalmente nos cloroplastos. No feijão, houve acentuada desorganização celular e uma diminuição no número e tamanho dos cloroplastos, os mesmos não apresentaram grãos de amido, mas sim um aumento no númerode glóbulos de plastídio. 
BARCELO et alii (1988) e NOGUEIRA et alii (1989) verificaram estes mes mos efeitos nas ultraestruturas celulares de feijão, quando tratadas com altas doses de Cd.

No arroz, os efeitos do $\mathrm{Ni}$ foram menores. Observou-se que o $\mathrm{Ni}$ afetou principalmente a organização dos cloroplastos com distorção e expansão dos tilacơides.

\subsubsection{Sintomatologia da toxidez de $\mathrm{Ni}$}

Em geral, os sintomas de toxidez de $\mathrm{Ni}$ incluem cloroses e muitos pontos necróticos na parte aérea do feijão e arroz. No feijoeiro, primeiro aparece uma clorose internervural nas folhas novas, observação também feita por HEWITT (1953) em dicotiledôneas. Esta clorose e pontos necróticos progridem rapidamente para folhas mais velhas e entrenós. Em estádios mais adiantados da toxidez as plantas apresentam, além dos sintomas acima descritos, diminuição no tamanho de folhas e entrenós, manchas necróticas nos pecíolos das folhas e caules, desfolha e fenecimento. No arroz, verificou-se uma clorose ao longo das nervuras, sendo que as folhas podem ficar completamente esbranquiçadas, semelhante aos sintomas de carência de ferro. Os sintomas tardios também incluem necrose das margens da folha e redução no número de folhas, perfilhos e raízes.

Com respeito as raỉzes, tanto no arroz como no feijoeiro, observou-se de modo geral, a partir de determinado nível de níquel, inibição no crescimento das raízes laterais, o sistema radicular ficou desprovido de raízes finas, e as raỉzes foram de reduzido tamanho, quebradiças, e de aparência coralóide. Em sorgo, CLARK et alii 
observaram que os sintomas de toxidez de níquel foram semelhantes aos ocasionados pelo excesso de cobalto e deficiência de ferro. Também os sintomas de toxidez de $\mathrm{Ni}$ descritos para arroz foram similares aos descritos por CHINO (1981). MISHRA \& KAR (1974) constataram que excessos de $\mathrm{Ni}$ podem causar distúrbios mitóticos nas pontas das raízes de algumas espécies de plantas, afetando os processos de divisão celular.

Plantas sob altos níveis de Ni na solução nutritiva apre sentaram inicialmente alterações na orientação das folhas e ligeira pigmentação bruno-avermelhada, principalmente nas nervuras de folhas primärias de feijão. RAUSER (1978) encontrou que esta cor bruno-avermelhada foi produto da deposição de compostos fenólicos, que poderiam ter origem no parênquima foliar contíguo aos vasos ou no fluido movimentado pelo próprio xilema. Enquanto que as alterações na orientação das folhas, poderiam dever-se à perda da função pulvinar, por mudanças no potencial de água nas folhas.

\subsection{Ensaios em solos}

5.2.1. Efeitos da toxidez de Ni em três solos äcidos

Os três solos estudados ( $V$, LRd e TE) apresentam caracte rísticas físico-químicas diferentes, enquanto que outras foram parecidas: solos de reação ácida e de textura argilosa.

Os efeitos das doses crescentes de $\mathrm{Ni}$ induziram diminuições na produção de matéria seca nas culturas de arroz e feijão. Observou-se uma maior produção de matéria seca no solo Vertissolo (V), em 
comparação aos outros dois solos (LRd e TE). Este fato revela que houve acentuada influência das características do solo que favorecem um melhor estado nutricional do solo Vertissolo. Estas características poderiam ser: elevado teor de matéria orgânica, argila de atividade bastante alta, alta CTC, elevado teor de bases $\left(\mathrm{Ca}^{2+}, \mathrm{Mg}^{2+}\right.$ e $\left.\mathrm{K}^{+}\right)$, alto teor de fósforo disponivel, entre outras.

Os efeitos da toxidez de Ni nos outros solos (LRd e TE), foram mais acentuados, podendo ter sido influenciados pela menor capacidade de adsorção de $\mathrm{Ni}$ (maior disponibilidade para as plantas) nestes so los, devido a que estes apresentaram argila de baixa atividade, baixo teor de matéria orgânica e elevado teor de óxidos de Fe e Al na fração argi1a. No sistema silicatado recoberto pelos óxidos, a CTC se reduz porque parte das cargas negativas do sistema silicatado são balanceadas com as cargas positivas dos óxidos. MISHRA \& KAR (1974) verificaram que o comportamento do Ni está influenciado por propriedades do solo como pH e teor de matéria orgânica, sendo que solos com pH menor que 5,5 apresentaram alta disponibilidade de $\mathrm{Ni}$, enquanto que a matéria orgânica diminui a sua disponibilidade.

Com relação aos nutrientes, as altas doses de $\mathrm{Ni}$ induzem a diminuição dos teores foliares de Ca, Mn e Zn no feijoeiro; e de Ca, $\mathrm{Mg}$, Mn e $\mathrm{Zn}$ no arroz. Tais interações antagônicas entre $\mathrm{Nix \textrm {Ca }}, \mathrm{Ni} \times \mathrm{Mg}$, Ni $x$ Mn e $\mathrm{Nix} \mathrm{Zn}$, têm sido relatadas na literatura para várias espécies de plantas (CROOKE \& INKSON, 1955; WALLACE et alii, 1977b; WALLACE et alii, 1977c; KHALID \& TINSLEY, 1980). 
Em aveia, WILLIAMS (1967) encontrara que altos teores de Mn no meio aumentaram a intensidade dos sintomas causados pelas altas doses de $\mathrm{Ni}$, sendo que os dois metais atuam em conjunto induzindo uma maior assimilação de Fe pela planta e inibindo sua participação nos processos metabólicos.

Existem correlações positivas, estatisticamente significativas, entre os teores de $\mathrm{Ni}$ nas folhas de arroz e feijão e as doses de $\mathrm{Ni}$ aplicadas aos três solos.

5.2.2. Efeitos da calagem no controle da toxidez de $\mathrm{Ni}$ em dois solos äcidos

Os principais fatores relacionados com a acidez do solo, que afetam o desenvolvimento das plantas, são o pH e sua influência sobre o $\mathrm{Al}^{3+}$ trocável, as bases trocáveis, o Mn solúvel e a disponibilidade de nutrientes. Ressalta-se, ainda, a importância da interação entre esses fatores, o que torna muito difícil separar seus efeitos isoladamente (JACKSON, 1963). Por outro lado, a utilização de material calcārio para neutralizar a acidez dos solos, torna-se necessária para melhorar as condições dos mesmos, como substrato de plantas. Adições de $\mathrm{Ni}$ no solo ácido, favorecem sua disponibilidade (Ni) para as plantas, devido ao baixo $\mathrm{pH}$, sendo que a calagem diminui os efeitos tóxicos do $\mathrm{Ni}$ (KABATA-PENDIAS \& PENDIAS, 1986).

Na ausência da calagem, a produção de matéria seca no fei joeiro foi limitada, nos dois solos estudados (LRd e TE). Diversos fatores de acidez do solo podem estar associados a essa limitação, além das doses crescentes de $\mathrm{Ni}$ aplicadas aos solos. 
As doses crescentes de $\mathrm{Ni}$ induzem uma diminuição na produção de matéria seca total nas culturas de arroz e feijão, nos dois so1os. No entanto, a calagem destes solos controla em parte os efeitos das altas doses de $\mathrm{Ni}$ na produção de matéria seca do feijoeiro. WALLACE et alii (1977c) encontraran que a calagem dos solos ácidos diminui os efeitos da toxidez de Ni no feijão. Por outro lado, no arroz não foram observadas respostas significativas da calagem no controle da toxidez de Ni, devido provavelmente, à presença de outros fatores limitantes no so10 .

A disponibilidade de $\mathrm{Ni}$ no solo é controlada pelo pH. Por tanto, a calagem de solos ácidos reduz a disponibilidade de $\mathrm{Ni}$ controlando os seus efeitos tóxicos nas plantas (CROOKE, 1956; MISHRA \& KAR, 1974; KABATA-PENDIAS \& PENDIAS, 1986). O níquel pode precipitar com hidróxidos, fosfatos, carbonatos e silicatos para formar componentes amorfos na fração do solo (GREENWOOD \& EARNSHAW, 1984). PRATT et alii (1964) verificaram a formação de complexos $\mathrm{Ni}-\mathrm{P}$ em valores de $\mathrm{pH} \geq 7$, reduzindo a toxidez de Ni no solo.

Com relação ao efeito da calagem nos teores de nutrientes e níquel, verifica-se uma melhora na assimilação de $N, P$ e $K$ no feijão e de P, Ca e Mg no arroz. Por outro lado, a calagem do solo reduz a disponibilidade de $\mathrm{Fe}$, Mn e Ni no feijão e de Mn e Ni no arroz, nos dois solos. A elevação do $\mathrm{pH}$ causa uma progressiva insolubilização desees elementos ( $\mathrm{Fe}, \mathrm{Mn}$ e $\mathrm{Ni}$ ) e, portanto, induz uma diminuição na sua disponibilidade no solo. LINDSAY (1972) mostra que a solubilidade de Fe e Mn decresce com a elevação do pH, sendo máxima quando o $\mathrm{pH}$ esteve entre os valores de 4 e 5. SADIQ \& ENFIELD (1984) observaram que a solubilidade 
do Ni também diminuiu com a elevação do $\mathrm{pH}$.

A elevação do pH do solo pela calagem, determinando o aumento da capacidade de adsorção de $\mathrm{Ni}$ pelos solos, tem sido usada para diminuir sua disponibilidade às plantas. Segundo CAVALLARO \& McBRIDE (1980), a elevação do pH de uma solução de solo pode levar à formação de produtos de hidrólise com diferentes afinidades pelas cargas permanentes e outros sitios de troca. Pode também, mudar a natureza dos sítios de troca hidrolizando ou precipitando íns $\mathrm{Al}^{3+}$, criando mais sítios de troca. Por outro lado, constituintes do solo com cargas dependentes de $\mathrm{pH}$ como óxidos de Fe e Al e matéria orgânica têm suas cargas negativas aumentadas pela elevação do $\mathrm{pH}$ do solo. Estes fenômenos induzem aumentos na capacidade de adsorção de $\mathrm{Ni}$ nos solos.

5.2.3. Ni-solúvel em DTPA-TEA em solos ácidos com e sem calagem

O nỉquel extraível ou solūvel em DTPA-TEA é utilizado como um indice para estabelecer a disponibilidade e mobilidade de $\mathrm{Ni}$ no solo. VALADARES et alii (1983) demonstraram que existe uma excelente correlação entre o teor de Ni-solúvel em DTPA-TEA e as doses de Ni adicionadas ao solo. Nos três solos ácidos estudados (V, LRd e TE) observa-se que os teores de Ni-solúvel em DTPA-TEA aumentam em relação às doses de $\mathrm{Ni}$ aplicadas ao solo.

Também existe um efeito da calagem de solos ácidos no teor de Ni-disponivel. A calagem do solo induz aumentos no pH, diminuindo a solubilidade do Ni. Em estudos de adsorção, a quantidade de $\mathrm{Ni}$ retido no solo foi dependente dos valores de $\mathrm{pH}$, sendo que a retenção de $\mathrm{Ni}$ no 
solo aumentou com o pH (HARTER, 1983).

MISRA \& PANDE (1974) verificaram que adições de Ni no so1o, resultam na diminuição do $\mathrm{pH}$ e do P-disponível no solo. PRATT et alii (1964) observaram que no solo formam-se precipitados de fosfatos de níquel, induzindo-se uma deficiência de P-disponỉvel. Em um experimento em vasos, CROOKE (1981) verificou que a elevação do $\mathrm{pH}$ do solo pela calagem, reduziu o $\mathrm{Ni}$ extraỉdo $\operatorname{com} \mathrm{CH}_{3} \mathrm{COONH}_{4} 1 \mathrm{~N} \mathrm{pH} 7$.

Por outro 1ado, observou-se que existem correlações negativas significativas $(P \leq 0,05)$ entre os teores de Ni-solúvel em DTPA-TEA nos três solos ( $V$, LRd e TE) e a produção de matéria seca total nas culturas de arroz e feijão. Portanto, existe um efeito direto do teor de níquel disponível sobre a produção de matéria seca. 
6. CONCLUSÕES

Os resultados obtidos permitiram estabelecer as seguintes conclusões:

1. As altas doses de $\mathrm{Ni}$ em solução nutritiva afetam negativamente a pro dução de matëria seca no $\operatorname{arroz}(4,8$ e 12ppm) e no feijão (2 e 4ppm).

2. Estes efeitos negativos do $\mathrm{Ni}$ são resultado da ação direta e indireta do elemento. O niquel age diretamente danificando as estruturas da planta, principalmente da raiz. A nível das ultraestruturas celulares de folhas ocorre a desorganização do sistema fotossintético. Desta forma, o teor de clorofila total nas folhas de arroz e feijão se reduz.

3. Indiretamente, o níquel afeta a absorção de nutrientes. No feijoeiro foram observadas interações do $\mathrm{Ni}$ com $\mathrm{O} \mathrm{Mg}$ e o $\mathrm{Fe}$. Enquanto que, no arroz estas interações do $\mathrm{Ni}$ foram com o $\mathrm{Ca}, \mathrm{Mg}$ e $\mathrm{Mn}$. 
4. Plantas de arroz e feijão, submetidas a altas doses de Ni, acumulam este elemento, principalmente, nas raízes. Existem correlações positivas significativas entre os teores de $\mathrm{Ni}$ nas partes de plantas de arroz e feijão, e as doses de Ni na solução nutritiva.

5. Observa-se um comportamento diferencial entre espécies de plantas (arroz e feijão), e entre cultivares e variedades, em relação a sua tolerância a doses altas de $\mathrm{Ni}$ em solução nutritiva. Plantas de arroz foram mais tolerantes que o feijoeiro. Entre cultivares de feijão, o IAPAR-14 foi mais tolerante, enquanto que entre variedades de arroz o IAC-165 parece ser um pouco mais tolerante a altas doses de Ni.

6. A sintomatologia característica dos efeitos da toxidez de $\mathrm{Ni}$, em plantas de arroz e feijão, consiste na presença de clorose internervural de folhas novas que progride para outras partes da planta. No arroz, as folhas podem ficar completamente esbranquiçadas. As raízes apresentam-se de reduzido tamanho, quebradiças e de aparência "coralöide".

7. Nos solos ácidos estudados (V, LRd e TE) doses crescentes de Ni afetaram negativamente a produção de matéria seca total do arroz e do feijão. A intensidade dos efeitos negativos foram menores no Vertissolo (V). Nos solos LRd e TE observaram-se correlações negativas significativas, com altos coeficientes de determinação, entre a produção de matéria seca e as doses crescentes de $\mathrm{Ni}$ aplicadas ao solo. 
8. Nos solos LRd e TE, a calagem diminui os efeitos negativos das doses crescentes de $\mathrm{Ni}$ na produção de matéria seca, principalmente no feijoeiro. Nota-se também que a calagem reduz os teores de Ni-solúvel em DTPA-TEA nos solos em que foram adicionadas doses crescentes de Ni.

9. Nos ensaios realizados em solos, tambémverificam-se efeitos de doses elevadas de Ni na absorção de nutrientes. Observam-se as seguintes interações: Ni x Ca e Ni x Zn no feijoeiro, e $\mathrm{Ni} \times \mathrm{Ca}, \quad \mathrm{Ni} \times \mathrm{Mg}$, Ni $x$ Mn e Ni $x$ Zn no arroz.

10. A calagem de solos ácidos (LRd e TE), que sofreram adições de doses crescentes de $\mathrm{Ni}$, aumenta os valores de $\mathrm{pH}$ e diminui os teores de Ni-disponível nơs solos, favorecendo uma menor absorção de Mn e Ni nas culturas de arroz e feijão.

11. Existe correlação negativa significativa entre o teor de Ni-solúvel em DTPA-TEA nos três solos (V, LRd e TE) e a produção de matéria seca total nas culturas de arroz e feijão. 
REFER $\widehat{E} N C I A S$ BIBLIOGRĀFICAS

ADRIANO, D.C. Trace elements in the terrestrial environment. New York, Springer-Verlag, 1986. 533p.

AGARWALA, S.C.; BISCHT, S.S.; SHARMA, C.P. Relative effectiveness of certain heavy metals in producing toxicity and symptons of deficiency in barley. Canadian Journal of Botany, Ottawa, 55:1299-307, 1977.

ANDERSON, A.J.; MEYER, D.R.; MAYER, F.K. Heavy metal toxicities. Australian Journal of Agricultural Research, East Melbourne, 24(4): $557-71,1973$.

ASSOCIATION OF OFFICIAL AGRICULTURAL CHEMIST. Official methods of analysis. 7.ed. Washington, 1950. 910p.

BAKER, D.E. \& AMACHER, M.C. Nickel, copper, zinc and cadmium. In: PAGE, A.L.; MILLER, R.H.; KEENEY, D.R., ed. Methods of soil analysis. Part 2. Chemical and microbiological properties. Madison, American Society of Agronomy, 1982. p.323-30. (Agronomy, 9). 
BARCELÕ, J. \& POSCHENRIEDER, Ch. Plant water relations as affected by heavy metal stress: a review. Journal of Plant Nutrition, New York, $13(1): 1-37,1990$.

BARCELŌ, J.; VĀSQUEZ, M.D.; POSCHENRIEDER, Ch. Strutural and ultrastructural disorders in cadmium treated bush bean plants (Phaseolus vulgaris L.). New Phytologist, Oxford, 108:37-49, 1988.

BERROW, M.L. \& REAVES, G.A. Total cinromium and nickel contents of Scottish soils. Geoderma, Amsterdam, 37(1):15-27, 1986.

BERROW, M.L. \& WEBBER, J. Trace elements in sewage sludges. Journal of the Science of Food and Agriculture, Essex, 23:93-4, 1972.

BETTIOL, W.; CARVALHO, P.C.T.; FRANCO, B.J. Utilização de lodo de esgoto como fertilizante. O Solo, Piracicaba, 75(1):44-54, 1983.

BLOOMFIELD, C. The translocation of metals in soils. In: GREENLAND, D. J. \& HAYES, M.H.B., ed. The chemistry of soil processes. New York, John Wiley, 1981. p.200-22.

BOUYOUCOS, G.J. A recalibration of the hydrometer methods for making analysis of soils. Agronomy Journal, Madison, 43:434-8, 1951.

BOWMAN, R.S.; ESSINGTON, M.E.; O'CONNOR, G.A. Soil sorption of nickel. Influence of solution composition. Soil Science Society of America Journal, Madison, 45:860-5, 1981. 
BROOKS, R.R. Accumulation of nickel by terrestrial plants. In: NRIAGU, J.0., ed. Nickel in the environment. New York, John Wiley, 1980. p. 407-30.

BROOKS, R.R.; WITHER, E.D.; ZEPERNICK, B. Cobalt and nickel in rinorea species. Plant and Soil, Dordrecht, 47(3):707-12, 1977.

BROWN, P.H.; WELCH, R.M.; CARY, E.E.; CHECKAI, R.T. Beneficial effects of nickel on plant growth. Journal of Plant Nutrition, New York, $10(9 / 16): 2125-35,1987$.

CAMARGO, O.A.; ROVERS, H.; VALADARES, J.M.A.S. Adsorção de níquel em latossolos paulistas. Revista Brasileira de Ciência do Solo, Campinas, 13:125-9, 1989 .

CATALDO, D.A.; GARLAND, T.R.; WILDUNG, R.E. Nickel in plants. II. Distribution and chemical form in soybean plants. Plant Physiology, Bethesda, 62:566-70, 1978 .

CAVALlARO, N. \& McBRIDE, M.B. Activities of $\mathrm{Cu}^{2+}$ and $\mathrm{Cd}^{2+}$ in soil solutions as affected by $\mathrm{pH}$. Soil Science Society of America Journal, Madison, 44:729-32, 1980.

CHAMEL, A. \& NEUMANN, P. Foliar absortion of nickel: Determination of its cuticular behaviour using isolated cuticles. Journal of Plant Nutrition, New York, 10(1):99-111, 1987. 
CHINO, M. Nickel. In: KITAGISHI, K. \& YAMANE, I., ed. Heavy metal pollution in soils of Japan. Tokyo, Japan Sciences Society Press, 1981. p.65-80.

CHINO, M. \& MITSUI, S. Ocurrence of heavy metal induced iron chlorosis in plants. Nippon Dojohiryogaki Zasshi, Bunkyo, 38:255-9, 1967.

CLARK, R.B.; PIER, P.A.; KNUDSEN, D.; MARANVILLE, J.W. Effect of trace element deficiencies and excesses on mineral nutrients in sorghum. Journal of Plant Nutrition, New York, 3(1/4):357-74, 1981.

COCUCCI, S.M. \& MORGUTTI, S. Stimulation of proton extrusion by $\mathrm{K}^{+}$and divalent cations $\left(\mathrm{Ni}^{2+}, \mathrm{Co}^{2+}, \mathrm{Zn}^{2+}\right)$ in maize root segments. Physiologia Plantarum, Copenhagen, 68(3):497-501, 1986.

CONNOR, J.; SHIMP, N.F.; TEDROW, J.C.F. A spectrographic study of the distribution of trace elements in some podzolic soils. Soil science, Baltimore, $83(1): 65-73,1957$.

COTTENIE, A.; CAMERLYNCK, R.; VERLOO, M.; DHAESE, A. Fractionation and determination of trace elements in plants, soils and sediments. Pure and Applied Chemistry, Oxford, 52(1):45-53, 1979.

CROOKE, W.M. Effect of nickel versenate on oat plants. Nature, London, $173: 403-4,1954$. 
CROOKE, W.M. Further aspects of the relation between nickel toxicity and iron supply. Annals of Applied Biology, Wellesbourne, 43:46576, 1955.

CROOKE, W.M. Effect of soil reaction on uptake of nickel from a serpentine soil. Soil Science, Baltimore, 81:269-76, 1956.

CROOKE, W.M. Effect of heavy metal toxicity on the cation exchange capacity on plant roots. Soil Science, Baltimore, 86:231-41, 1958.

CROOKE, W.M. Nickel uptake from a serpentine soil. Soil Science, Baltimore, 81:269-73, 1981 .

CROOKE, W.M. \& INKSON, R.H.E. Relation between nickel toxicity and major nutrient supply. Plant and Soil, Dordrecht, 6:1-15, 1955.

DAVIS, R.D.; BECKETT, P.H.; WOLLAN, E. Critical levels of twenty potentially toxic elements in young spring barley. Plant and Soir, Dordrecht, 49:395, 1978.

DIXON, N.E.; GAZZOLA, C.; BLAKELEY, R.L.; ZERNER, R. Jack bean urease. A metalloenzyme. A simple biological role for nickel. Joumal of the American Chemical Society, Washington, 97:4131-3, 1975.

EMMERICH, W.E.; LUND, L.J.; PAGE, A.L.; CHANG, A.C. Movement of heavy metals in sewage sludge treated soils. Journal of Environmental Quality, Madison, 11(2):174-8, 1982. 
ESKEW, D.L.; WELCH, R.M.; CARY, E.E. Nickel, an essential micronutrient for legumes and possibly all higher plants. Science, Washington, $222: 621-3,1983$.

ESKEW, D.L.; WELCH, R.M.; NORVEL, W.A. Nickel in higher plants. Further evidence for an essential role. Plant Physiology, Bethesda, 76:6913,1984 .

ESTAÑ, M.T.; BOLARIN, M.C.; ROMERO, M. Adsorción de niquel por suelos calizos, ajuste a las isotermas de Freundich y Freundich-Sibbesen. Anales de Edafologia y Agrobiologia, Madrid, 44:131-42, 1985.

FORSTER, W.A. Toxic effect of heavy metals on crop plants grown in soil culture. Annals of Applied Biology, Wellesbourne, 41:637-51, 1954.

FOY, C.D.; CHANEY, R.L.; WHITE, M.C. The physiology of metal toxicity in plants. Annual Review of Physiology, Palo Alto, 29:511-66, 1978.

GANJE, T.J. \& PAGE, A.L. Rapid acid dissolution of plant tissue for cadmium determination by atomic absortion spectrophotometry. Atomic Absortion Newsletter, Norwaik, 13(6):131-4, 1974.

GOLOVCHENKO, V.P. \& CHEREDNICHENKO, C.V. Content of trace elements in various plant organs. Doklady Akademii Nauk SSSR, Leningrad, 146: 1223-6, 1962 .

GRANICK, S. Biosynthesis of chlorophyll and related pigments. Annual Review of Plant Physiology, Palo Alto, 2:115-44, 1951. 
GREENWOOD, N.N. \& EARNSHAW, A. Chemistry of the elements. Oxford, Pergamon Press, 1984. 1542p.

HALE, J.C.; ORMROD, D.P.; LAFFEY, P.J.; ALLEN, O.B. Effects of nickel and copper mixtures on tomato in sand culture. Environmental Pollution, Essex, $39(1): 53-69,1985$.

HALSTEAD, R.L. Effect of different amendments on yield and composition of oats grown on a soil derived from serpentine material. Canadian Journal of Soil Science, Ottawa, 48:301-5, 1968.

HALSTEAD, R.L.; FINN, B.J.; McLEAN, A.J. Extractibility of nickel added to the soils and its concentration in plants. Canadian Journal of Soir Science, Ottawa, 49:335-42,. 1969.

HAQ, A.U.; BATES, T.E.; SOON, Y.K. Comparison of extractants for plantavailable zinc, cadmium, nickel and copper in contaminated soils. Soir Science Society of America Joumal, Madison, 44(4):772-7, 1980.

HARTER, R.D. Effect of soil pH on adsorption of lead, copper, zinc, and nickel. Soil Science Society of America Journal, Madison, 47:47-51, 1983.

HEESE, P.R. A textbook of soils chemical analysis. London, John Murray, 1971. 520p. 
HEWITT, E.J. Metal interrelationships in plant nutrition. I. Effects of some metal toxicities on sugar beet, tomato, oat, potato and narrow stem kale grown in sand culture. Journal of Experimental Botany, Oxford, 4:59-64, 1953 .

HOAGLAND, D.R. \& ARNON, D.I. The water culture method for growing plant without soil. Berkeley, California Agricultural Experiment Station, 1950. (Circular, 347).

HUNTER, J.G. \& VERGNANO, O. Nickel toxicity in plants. Annals of Applied Biology, Wellesbourne, 39:279-84, 1952.

HUNTER, J.G. \& VERGNANO, 0 . Trace element toxicities in oat plants. Annals of Applied Biology, Wellesbourne, 40:761-77, 1953.

HUTCHINSON, T.C. Nickel. In: LEPP, N.W., ed. Effect of heavy metal pollution on plants. London, Applied Sciences, 1981. v.1, p.171211 .

JACKSON, W.A. Aluminium bonding in soils: a unifying principle in soil science. Proceedings in Soil Science of American Society, Madison, $27: 10-5,1963$.

JENNE, E.A. Controls of $\mathrm{Mn}, \mathrm{Fe}, \mathrm{Co}, \mathrm{Ni}, \mathrm{Cu}$ and $\mathrm{Zn}$ concentrations in soils and water; the significant role of hydrous $\mathrm{Mn}$ and $\mathrm{Fe}$ oxides. Advances in Chemistry Series, Washington, 73:337-87, 1968. 
JORGENSEN, S.S. Some methods used for rutine chemical analysis; laboratory manual. Piracicaba, Centro de Energia Nuclear na Agricultura, 1977. 22p.

KABATA-PENDIAS, A. \& PENDIAS, H. Trace elements in soils and plants. Florida, CRC Press, 1986. 315p.

KERNDORFF, H. \& SCHNITZER, M. Sorption of metals on humic acids. Geochimica et Cosmochimica Acta, Elmsford, 44(11):1701-8, 1980. Apud Soil and Fertilizers, Farnham Roya1, 44(6):523, June 1981. (Resumo).

KHALID, B.Y. \& TINSLEY, J. Some effects of nickel toxicity on rye grass. Plant and Soil, Dordrecht, 55:139-44, 1980.

KLUCAS, R.V.; HANUS, F.J.; RUSSELL, S.A.; EVANS, H.J. Nickel, a micronutrient for hidrogen dependent growth of Rhizobium japonicum and for expression of urease activity in soybean leaves. Proceedings of the National Academy of Sciences of USA., Washington, 80:2253-7, 1983.

KORTE, N.F.; SKOPP, J.S.; NIEBLA, E.F.; ALESSI, B.A. Trace elements movement in soils; influence of soil physical and chemical properties. Soil Science, Baltimore, 122:350-9, 1976.

LAU, 0. \& YANG, S.F. Inhibition of ethylene production by cobaltous ion. Plant Physiology, Bethesda, 58:114-7, 1976. 
LE RICHE, H.H. \& WEIR, A.H. A method of studying trace elements in soil fractions. Journal of Soil Science, Oxford, 14:225-35, 1963.

LEE, J.; REEVES, R.D.; BROOKS, R.R.; JOFFRE, T. The relation between nickel and citric acid in some nickel acumulating plants. Phytochemistry, Oxford, $17(6): 1033-5,1978$.

LEVAN, A. Cytological reactions induced by inorganic salts. Nature, Lond on, 156:751-2, 1945.

LINDSAY, W.L. Inorganic phase equilibria of micronutrients in soils. In: MORTVEDT, J.J.; GIORDANO, P.M.; LIND, W.L. Micronutrients in agriculture. Madison, Soil Science Society of America, 1972. p.4157 .

LINDSAY, W.L. \& NORVELL, W.A. Development of a DTPA soil test for zinc, iron, manganese, and copper. Soil Science Society of America Journal, Madison, 48:421-8, 1978 .

LO, T.Y. \& CHEN, S.M. Vitamin P content of vegetables as influenced by chemical treatment. Food Research, Champaign, 11:159-62, 1946.

LO, T.Y. \& WU, C.H. The effect of various elements on the formation of yitamin $P$ in germinated mung beans. Journal of the Chinese Chemical Society, Peiping, 10:60-4, 1943. 
LOZANO, F.C. \& MORRISON, I.K. Disruption of hardwood nutrition by sulfur dioxide, nickel and copper air pollution near Sudbury, Canadá. Journal of Environmental Quality, Madison, 10(2):198-204, 1981.

MALAVOlTa, E. Deficiência de macro e micronutrientes e toxidez de Cl, Mn e Al no sorgo sacarino (Sorghum bicolor L.). Piracicaba, Centro de Energia Nuclar na Agricultura, 1979. 12p.

MALAVolta, E. Elementos de nutrição mineral de plantas. São Paulo, Agro nômica Ceres, 1980. 251p.

MARTINI, A. Der phytomikrochemische nachweis des nickels und sein vorkommen im pflanzenreich. Mikrochemie, Wien, 8:41-5, 1930.

MENGEL, K. \& KIRKBY, E.A. Principles of plant nutrition. 3.ed. Bern, International Potash Institute, 1982. 655p.

MILLER, R.J.; DUMFORD, S.W.; KOEPPEO, D.E.; HANSON, J.B. Divalent cation stimulation of substrate oxidation by corn mitochondria. Plant Physiology, Bethesda, 45:649-53, 1970.

MISHRA, D. \& KAR, M. Nickel in plant growth and metabolism. The Botanical Review, New York, 40(4):395-449, 1974.

MISRA, S.G. \& DWIVEDI, R.S. Residual effect of iron-nickel interactions on the availability of nutrients. Plant and Soil, Dordrecht, 48: 705-8, 1977. 
MISRA, S.G. \& PANDE, P. Effect of organic matter on availability of nickel. Plant and Soil, Dordrecht, 40:679-84, 1974.

MITCHELL, R.L. Cobalt and nickel in soils and plants. Soil Science, Baltimore, 60:63-70, 1945.

MIZUNO, N. Interaction between iron and nickel, and copper and nickel in various plant species. Nature, London, 219:1271-2, 1968.

NAKOS, G. Pollution of soil and vegetation in the Thriasian Plain, Greece. Plant and Soil, Dordrecht, 66(2):271-7, 1982.

NIELSEN, F.H. \& OLLERICH, D.A. Nickel, a new essential trace element. Federation Proceeedings, Bethesda, 33:1767-71, 1974.

NIETHAMMER, A. The influence of heavy metal compounds on plant cells. Protoplasma, Vienna, 12:554-8, 1931.

NOGUEIRA, N.L.; JURADO, S.G.; LANZONI, M.; GOMES, J.E. Estudos a nível de microscopia eletrônica dos efeitos do cadmio no feijoeiro (Phaseolus vulgaris L.) cultivado em soluções nutritivas. In: ANAIS DO COLÓQUIO DA SOCIEDADE BRASILEIRA DE MICROSCOPIA ELETRÔNICA, 12., CAXAMBU, 1989. Anais. s.1. SMBE, 1989. v.1, p.83-4.

PAINTER, L.I.; TOTH, J.S.; BEAR, F.E. Nickel status of New Jersey soils. Soil Science, Baltimore, 75:421-9, 1953. 
PAVAN, M.A. \& BINGHAM, F.T. Toxidez de metais em plantas. II. Caracterização da toxidez de níquel em cafeeiros. Pesquisa Agropecuária Bra sileira, Brasilia, $17(2): 323-8,1982$.

POLACCO, J.C. \& HAVIR, E.A. Comparisons of soybean urease isolated from seed and tissue culture. Joumal of Biological Chemistry, Baltimore, 254:1707-15, 1979 .

POMBO, L.; SALGADO, V.; VOLKWEISS, S.; KLAMT, E. Adsorção de níquel por dois solos: Terra Bruna Estruturada similar e Podzólico Vermelho Amarelo. Pesquisa Agropecuäria Brasileira, Brasilia, 24(5):593-8, 1989.

PRATT, P.F.; BAIR, F.L.; McLEAN, G.W. Reactions of phosphate with soluble and exchangeable nickel. Soil Science Society of America Proceedings, Madison, 28:363-5, 1964.

RAIJ, B. van \& QUAGGIO, J.A. Métodos de anälise de solo para fins de fertilidade. Campinas, Instituto Agronômico de Campinas, 1983. 31p. (Boletim Técnico, 81).

RAIJ, B. van \& VALADARES, J.M.A.S. Análise dos elementos maiores de rochas, argilas e solos. Campinas, Instituto Agronômico, 1974. 23p. (Boletim Técnico, 16).

RAUSER, W.E. Early effects of phytotoxic burdens of cadmium, cobalt, nickel, and zinc in white beans. Canadian Journal of Botany, Ottawa, $56(15): 1744-9,1978$. 
RAUSER, W.E. \& DUMBROFF, E.B. Effects of excess cobalt, nickel and zinc on the water relations of Phaseolus vulgaris. Environmental and Experimental Botany, Oxford, 21(2):249-55, 1981.

RAUSER, W.E. \& SAMARAKOON, A.B. Vein loading in seedlings of Phaseolus vulgaris exposed to excess cobalt, nickel, and zinc. Plant Physiology, Bethesda, 65:578-83, 1980.

REHAB, F.I. \& WALLACE, A. Excess trace metal effects on cotton: 5. Nickel and cadmium in solution culture. Communications in Soil Science and Plant Analysis, New York, 9(8):771-8, 1978.

RICHTER, R.0. \& THEIS, T.L. Nickel speciation in a soil water system. In: NRIAGU, J.0., ed. Nickel in the environment. New York, John Wiley, 1980. p.189-202.

ROVERS, H.; CAMARGO, O.A.; VALADARES, J.M.A.S. Níquel total e solūvel em DTPA em solos do estado de São Paulo. Revista Brasileira de Ciên cia do Solo, Campinas, 7:217-20, 1983.

RUSSELL, S.A.; EVANS, H.J.; MAYEUX, P. The effect of cobalt and certain other trace metals on the growth and vitamin $B_{12}$ content of Alnus rubra. In: SYMPOSIUM ON BIOLOGY OF ALDER, 40., Alder, 1968. Proceedings. Apud Soil and Fertilizers, Farnham Royal, $32(6): 596$, Dec. 1969. (Resumo). 
SADIQ, M. \& ENFIELD, C.G. Solid phase formation and solution chemistry of nickel in soils. 1. Theoretical. Soil Science, Baltimore, 138 (4):262-70, 1984 .

SATO, K. Antagonism between nickel and molybdenum in citrus. In: INTERNATIONAL CITRUS SYMPOSIUM, 1., Riverside, 1968. Proceedings, edited by H.P. Chapman. Riverside, University of California, 1969. v. 3, p. 1543-50.

SCHNITZER, M. \& KHAN, S.U. Soil organic matter, Amsterdam, Elsevier, 1978. 319p.

SCHNITZER, M. \& SKINNER, S.I.M. Alkali versus acid extraction of soil organic matter. Soil Science, Baltimore, 105:392-6, 1968.

SEVERNE, B.C. Nickel accumulation by Hibanthus floribundus. Nature, London, 248:807-8, 1974 .

SHEORAN, I.S.; SINGAL, H.R.; SINGH, R. Effect of cadmium and nickel on photosynthesis and the enzymes of the photosynthetic carbon reduction cycle in pigeon pea (Cajanus cajan L.). Photosynthesis Research, Dordrecht, 23:345-51, 1990.

SHEWRY, P.R. \& PETERSON, P.J. Distribution of chromium and nickel in plants and soil from serpentine and other sites. Joumal of Ecology, Oxford, $64(1): 195-212,1976$. 
SHIMADA, N.; ANDO, T.; TOMIYAMA, M.; KAKU, H. Role of nickel in plant nutrition. Nippon Dojohiryogaku Zasshi, Bunkyo, 51:487-92, 1980.

SIDERIS, C.P. \& YOUNG, H.Y. Growth and chemical composition of Ananus comosus (L.) Merr. in solution cultures with different iron-manganese ratios. Plant Physiology, Bethesda, 24:416, 1949.

SOANE, B.D. \& SAUNDER, D.H. Nickel and chromium toxicity of serpentine soils in Southern Rhodesia. Soil Science, Baltimore, 88:322-30, 1959.

SPOSITO, G. \& MATTIGOD, S.V. GEOCHEM, a computer progrom for the calculations of chemical equilibria in soil solutions and other natural water systems. Riverside, University of California, Kearney Foundation of Soil Science, 1980. 82p.

THAUER, R.K.; DIEKERT, G.; SCHONHEIT, P. Biological role of nickel. Trends in Biochemical Sciences, Cambridge, 5:304-6, 1980.

THOMAS, R.J. \& SCHRADER, L.E. Ureide metabolism in higher plants. Phytochemistry, 0xford, 20:361-71, 1981.

TIFFIN, L.0. Translocation of nickel in xylem exudate of plants. Plant Physiology, Bethesda, 48:273-7, 1971.

TURINA, B. Absortion of selenium, sulfur, tellurium, potassium, magnesium, iron, nickel and chromium ions by plant roots. Agronomski Glasnit, Zagreb, 30:919-50, 1968. 
TYLER, L.D. \& MCBRIDE, M.B. Mobility and extractability of cadmium, copper, nickel, and zinc in organic and mineral soil columns. Soil Science, Baltimore, 134(3):198-205, 1982.

VALADARES, J.M.A.S.; GAL, M.; MINGELGRIN, U.; PAGE, A.L. Some heavy metals in soils treated with sewage sludge, their effects on yield, and their uptake by plants. Joumal of Environmental Quality, Madison, $12: 49-57,1983$.

VAN BAALEN, C. \& O'DONNELL, R. Isolation of a nickel dependent bluegreen algae. Journal of General Microbiology, Reading, 105:351-3, 1978.

VANSELOW, A.P. Microelement research with citrus. Califormia Citrograph, Los Angeles, 37(2):77-80, 1951.

VANSELOW, A.P. Nickel. In: CHAPMAN, H.D., ed. Diagnostic criteria for plants and soils. Abilene, Quality Printing, 1965. p.302-9.

VETTORI, L. Métodos de análises de solos. Rio de Janeiro, Ministério da Agricultura / Equipe de Pedologia e Fertilidade do Solo, 1969. 24p. (Boletim Técnico, 7).

VINOGRADOV, A.P. The geochemistry of rare and dispersed chemical elements in soils. New York, Consultants Bureau, 1959. 374p. 
WALKER, C.D.; GRAHAM, R.D.; MADISON, J.T.; CARY, E.E.; WELCH, R.M. Effects of nickel deficiency on some nitrogen metabolites in cowpeas (Vigna ungiculata L. Walp.). Plant Physiology, Bethesda, 79(2): $474-9,1985$.

WALKLEY, A. \& BLACK, I.A. An examination of the Degtijareff method for determining soil organic matter and a proposed modification of the chromic acid titration method. Soil Science, Baltimore, 37:29-38, 1934.

WALLACE, A.; ROMNEY, E.M.; CHA, J.W. Nickel-iron interactions in bush beans. Communications in Soil Science and Plant Analysis, New York, $8(9): 787-90,1977 a$

WALLACE, A.; CHA, J.W.; CHAUDHRY, F.M.; KINNEAR, J.; ROMNEY, E.M. Tolerance of rice plants to trace metals. Communications in Soil Science and Plant Analysis, New York, 8(9):809-17, 1977b.

WALLACE, A.; ROMNEY, E.M.; CHA, J.W.; SOUFI, S.M.; CHAUDHRY, F.M. Nicke1 phytotoxicity in relationship to soil $\mathrm{pH}$ manipulation and chelating agents. Communications in Soil Science and Plant Analysis, New York, $8(9): 757-64,1977 c$.

WATANABE, Y. \& SHIMADA, N. Effect of nickel on the plant growth and urea assimilation in higher plants. In: INTERNATIONAL CONGRESS OF SOIL SCIENCE, 14., KYOTO, 1990. Transactions. s.1., ISSS, 1990. v. $4, \mathrm{p} \cdot 146-51$. 
WELCH, R.M. The biological significance of nickel. Journal of Plant Nutrition, New York, 3(1/4):345-56, 1981.

WHITBY, L.M.; GAYNOR, J.; MacLEAN, A.J. Metals in soils of some agricultural watersheds in Ontario. Canadian Journal of Soil Science, Ottawa, $58(3): 325-30,1978$.

WILLIAMS, P.C. Nickel, iron, and manganese in the metabolism of the oat plant. Nature, London, 214:628, 1967. 
A $P \widehat{E} N D I C E S$ 
Apêndice 1. Equações de regressão entre produção de matēria seca de par tes da planta (Y), em g/vaso, e ppm de níquel (X) na solução nutritiva (Ensaio 1 ).

\begin{tabular}{|c|c|c|c|c|}
\hline VARIĀVEL & & EQUAÇÃO DE REGRESSÃO & $R^{2}$ & F \\
\hline Cultura & Parte & & & \\
\hline \multirow[t]{4}{*}{ Feijão } & Folha & $Y=7,045-1,475 X+0,067 x^{2}$ & 0,91 & $* *$ \\
\hline & $\begin{array}{l}\text { Caule + } \\
\text { Ramo }\end{array}$ & $Y=5,176-1,183 X+0,055 X^{2}$ & 0,86 & $* *$ \\
\hline & Raiz & $Y=2,113-0,472 X+0,022 X^{2}$ & 0,91 & $* *$ \\
\hline & Total & $Y=14,334-3,130 X+0,143 X^{2}$ & 0,91 & $* *$ \\
\hline \multirow[t]{4}{*}{ Arroz } & Folha & $Y=8,325-0,509 \quad X$ & 0,94 & $* *$ \\
\hline & $\begin{array}{l}\text { Colmo }+ \\
\text { Perfilho }\end{array}$ & $Y=8,882-0,903 x+0,021 x^{2}$ & 0,97 & $* *$ \\
\hline & Raiz & $Y=8,250-0,531 X$ & 0,90 & $* *$ \\
\hline & Total & $Y=24,887-1,597 x$ & 0,94 & $* *$ \\
\hline
\end{tabular}

(**) Significativo ao nível de $1 \%$ 
ت्ञ

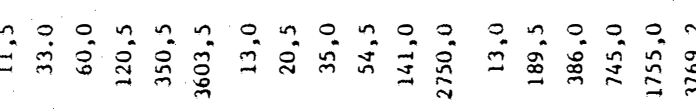

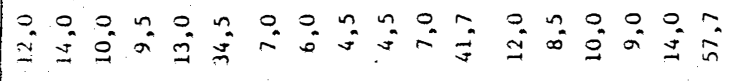

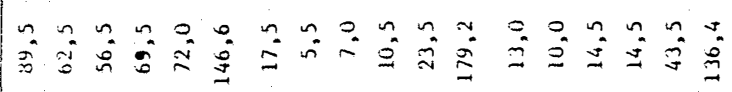

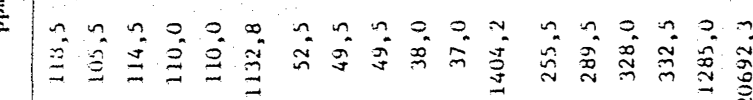

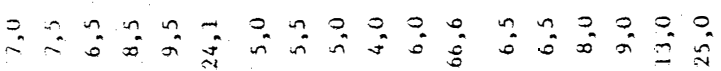

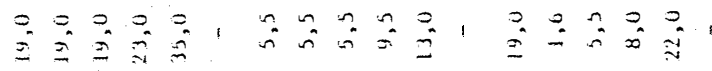

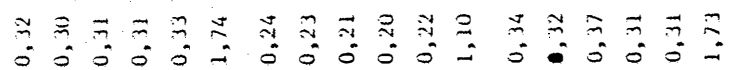

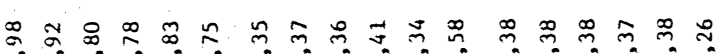

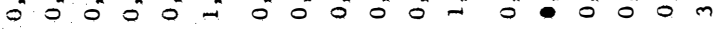

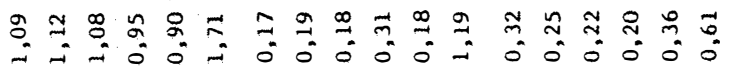
요

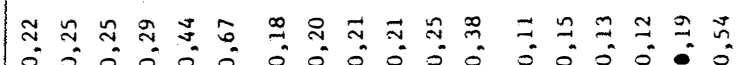

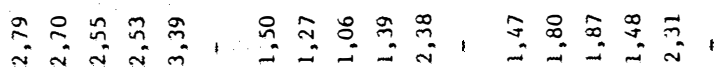

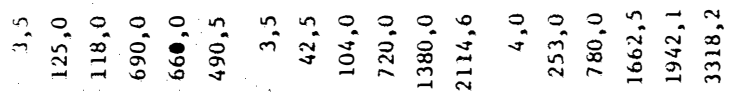

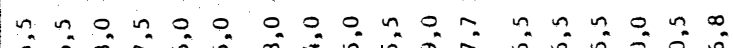

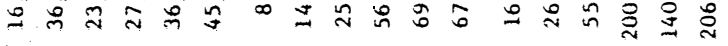

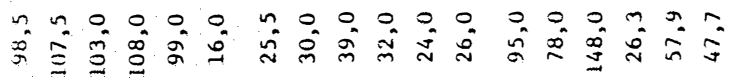

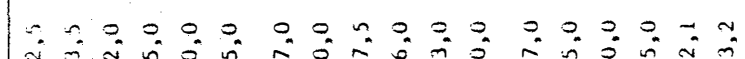

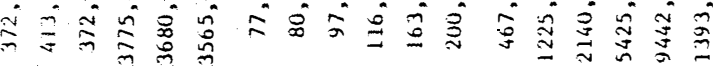

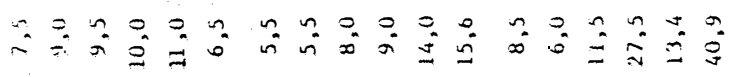

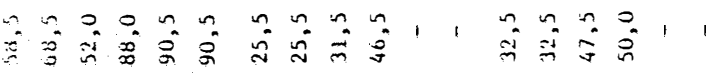

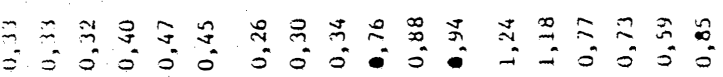

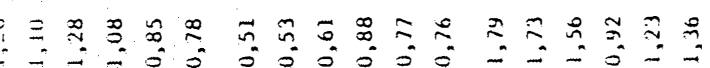

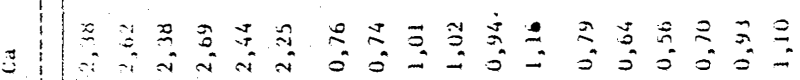

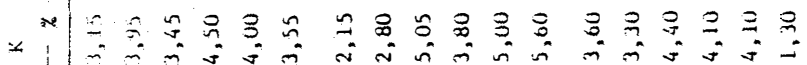

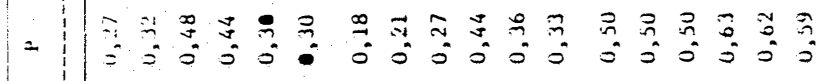
z z烂 $=-\alpha+\infty$

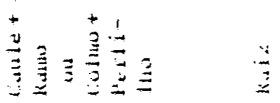




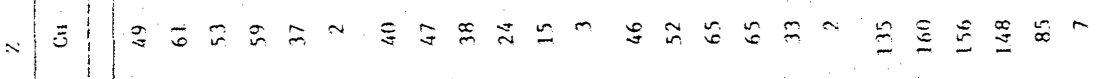

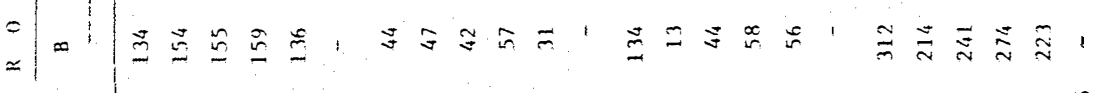

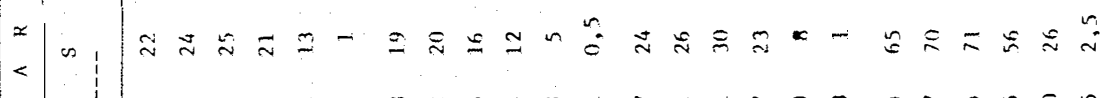

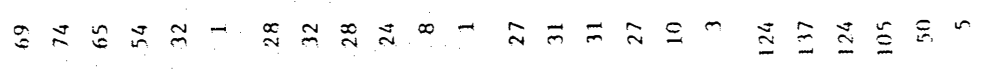

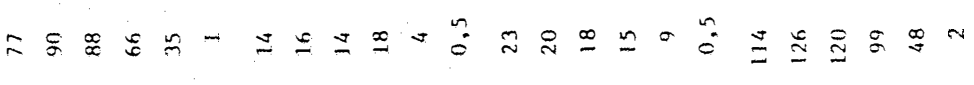

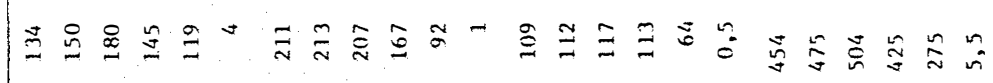

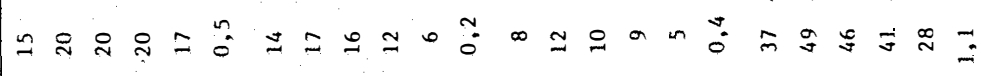

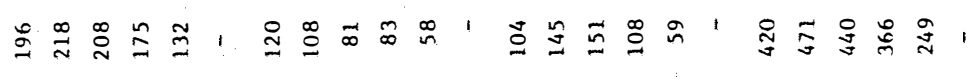
$\stackrel{n}{\widetilde{Z}}$

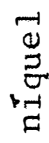
a

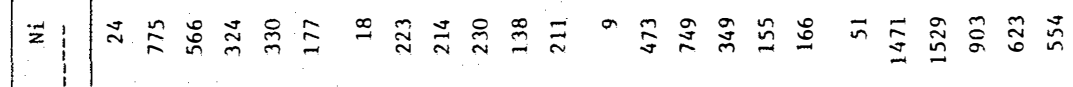

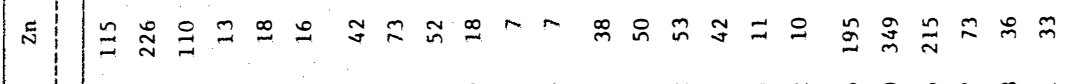
둘

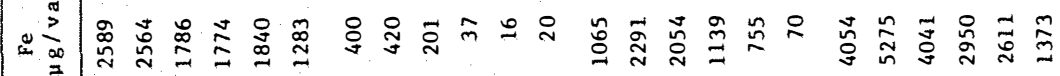

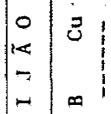

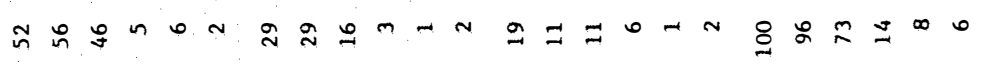

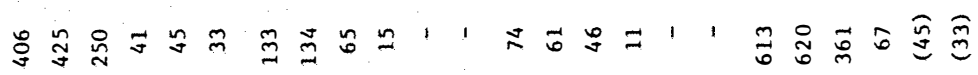

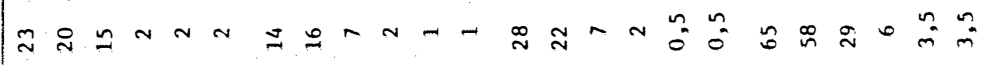

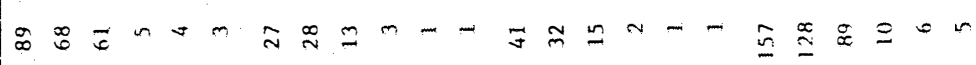

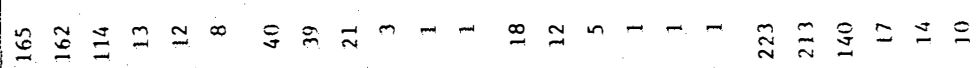

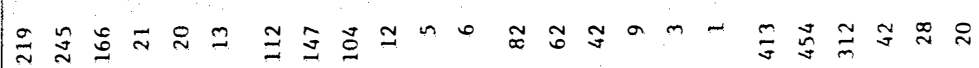

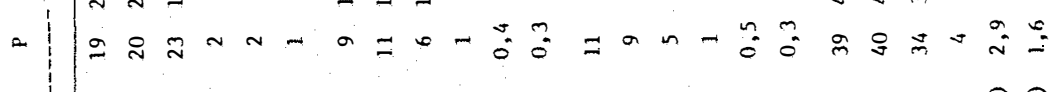

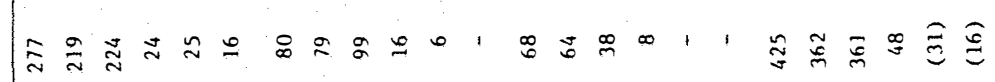
$\dot{m}$ 
Apêndice 4. Equações de regressão entre produção de matéria seca (g/vaso) e teor de clorofila total na folha ( $\mu \mathrm{g} / \mathrm{g}$ de matéria fres ca) do feijoeiro (Y), e ppm de níquel (X) na solução nutriti va (Ensaio 2).

\begin{tabular}{llll}
\hline VARIĀVEL & EQUAÇÃO DE REGRESSÃO & $\mathrm{R}^{2}$ & $\mathrm{~F}$ \\
\hline Folha & $\mathrm{Y}=6,961-0,514 \mathrm{X}+0,278 \mathrm{X}^{2}$ & $0,99 * * *$ \\
Caule + Ramo & $\mathrm{Y}=5,567-1,348 \mathrm{X}$ & $0,89 * *$ \\
Raiz & $\mathrm{Y}=2,264-0,535 \mathrm{X}$ & $0,97 * *$ \\
Total & $\mathrm{Y}=15,348-3,548 \mathrm{X}$ & $0,97 * * *$ \\
Clorofila & $\mathrm{Y}=1755,47-217,74 \mathrm{X}$ & $0,94 * *$ \\
\hline
\end{tabular}

Apêndice 5. Equações de regressão entre quantidades de macro (mg/vaso) e micronutrientes ( $\mu g / v a s o$ ) do feijoeiro (Y), e ppm de níquel (X) na solução nutritiva (Ensaio 2).

\begin{tabular}{|c|c|c|c|c|}
\hline VARIĀVEL & & EQUAÇÃO DE REGRESSÃO & $R^{2}$ & F \\
\hline Parte & Nutriente & & & \\
\hline Folha & $\begin{array}{l}\mathrm{S} \\
\mathrm{Cu} \\
\mathrm{Fe} \\
\mathrm{Mn} \\
\mathrm{Zn}\end{array}$ & $\begin{array}{l}Y=24,4-5,371 X \\
Y=61,8-12,6 X \\
Y=2581,4-230,37 X \\
Y=766-166,857 X \\
Y=178,8-35,886 X\end{array}$ & $\begin{array}{l}0,98 \\
0,84 \\
0,73 \\
0,93 \\
0,49\end{array}$ & $\begin{array}{r}* \\
* \\
\mathrm{~ns} \\
* \\
\mathrm{~ns}\end{array}$ \\
\hline Total & $\begin{array}{l}\mathrm{P} \\
\mathrm{Mg} \\
\mathrm{Cu} \\
\mathrm{Fe} \\
\mathrm{Mn}\end{array}$ & $\begin{array}{l}Y=39,082-3,859 X-3,159 X^{2} \\
Y=161,2-37,257 X \\
Y=110,2-22,543 X \\
Y=4760,6-388,91 X \\
Y=1138,8-252,46 X\end{array}$ & $\begin{array}{l}0,999 \\
0,996 \\
0,94 \\
0,49 \\
0,95\end{array}$ & $\begin{array}{r}* \\
* \\
* \\
\text { ns } \\
*\end{array}$ \\
\hline
\end{tabular}

(**) Significativo ao nível de $1 \%$

(*) Significativo ao nível de $5 \%$

(ns) Não significativo 
Apêndice 6. Equações de regressão entre produção de matéria seca (g/vaso) e teor de clorofila total nas folhas ( $\mu \mathrm{g} / \mathrm{g}$ de matéria fresca) do feijoeiro ( $Y$ ), e ppm de níquel (X) na solução nutritiva (Ensaio 3).

\begin{tabular}{|c|c|c|c|c|c|c|}
\hline \multicolumn{3}{|c|}{ VARI $\bar{A} V E L$} & \multicolumn{2}{|c|}{ EQUAÇÃO DE REGRESSÃO } & \multirow[t]{2}{*}{$R^{2}$} & \multirow[t]{2}{*}{ F } \\
\hline Coleta & Parte & Cultivar & & & & \\
\hline \multirow[t]{3}{*}{1} & Raiz & Carioca & $Y=3,707$ & $-0,896 x$ & 0,97 & $* *$ \\
\hline & & IAPAR-14 & $Y=2,994$ & $-0,599 x$ & 0,98 & $* *$ \\
\hline & Total & - & $Y=23,909$ & $-5,274 x$ & 0,97 & $* *$ \\
\hline \multirow[t]{7}{*}{2} & Caule + & Carioca & $Y=13,508$ & $-3,348 x$ & 0,95 & $* *$ \\
\hline & Ramo & IAPAR-14 & $Y=9,378$ & $+2,17 x-0,975 x^{2}$ & 0,99 & $* *$ \\
\hline & Raiz & Carioca & $Y=4,111$ & $-1,895 x+0,228 x^{2}$ & 0,99 & * \\
\hline & & IAPAR-14 & $Y=3,204$ & $-0,577 x$ & 0,95 & $* *$ \\
\hline & Total & Carioca & $Y=28,514$ & $-7,043 x$ & 0,97 & $* *$ \\
\hline & & IAPAR -14 & $Y=22,403$ & $+2,698 x-1,641 x^{2}$ & 0,99 & $* *$ \\
\hline & Total & - & $Y=26,066$ & $-3,43 x-0,517 x^{2}$ & 0,99 & * \\
\hline \multicolumn{3}{|c|}{ Clorofila } & $Y=1357,26$ & $6-8,51 x-37,22 x^{2}$ & 0,99 & $* *$ \\
\hline
\end{tabular}

(**) Significativo ao nível de $1 \%$

(*) Significativo ao níve1 de $5 \%$ 
Apêndice 7. Equações de regressão entre teores de nutrientes e níquel (\% e ppm) em feijoeiro (Y), e ppm de níquel (X) na solução
nutritiva (Ensaio 3 ).

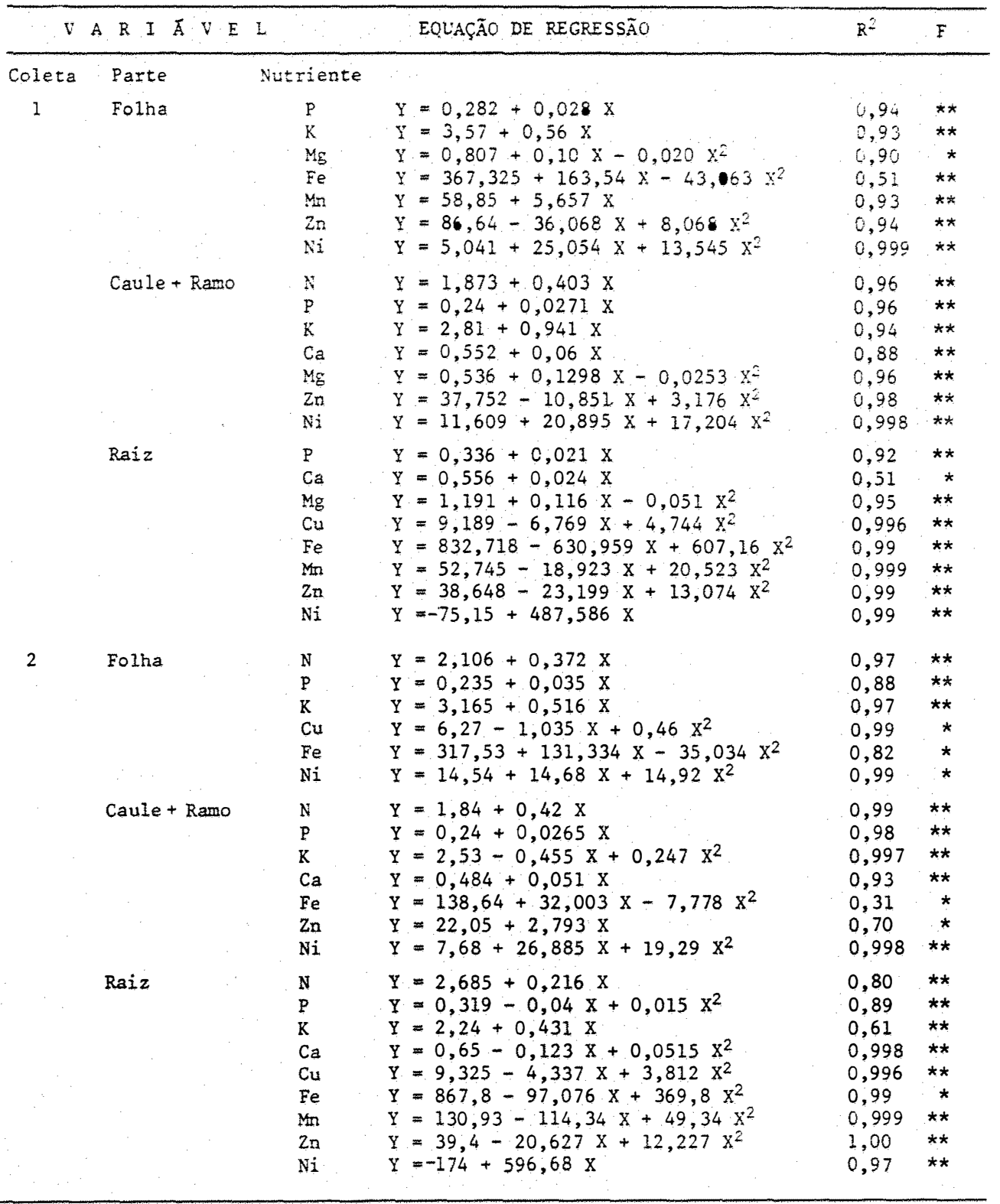

(**) Significativo ao nível de $1 \%$

(*) Significativo ao nível de $5 \%$ 


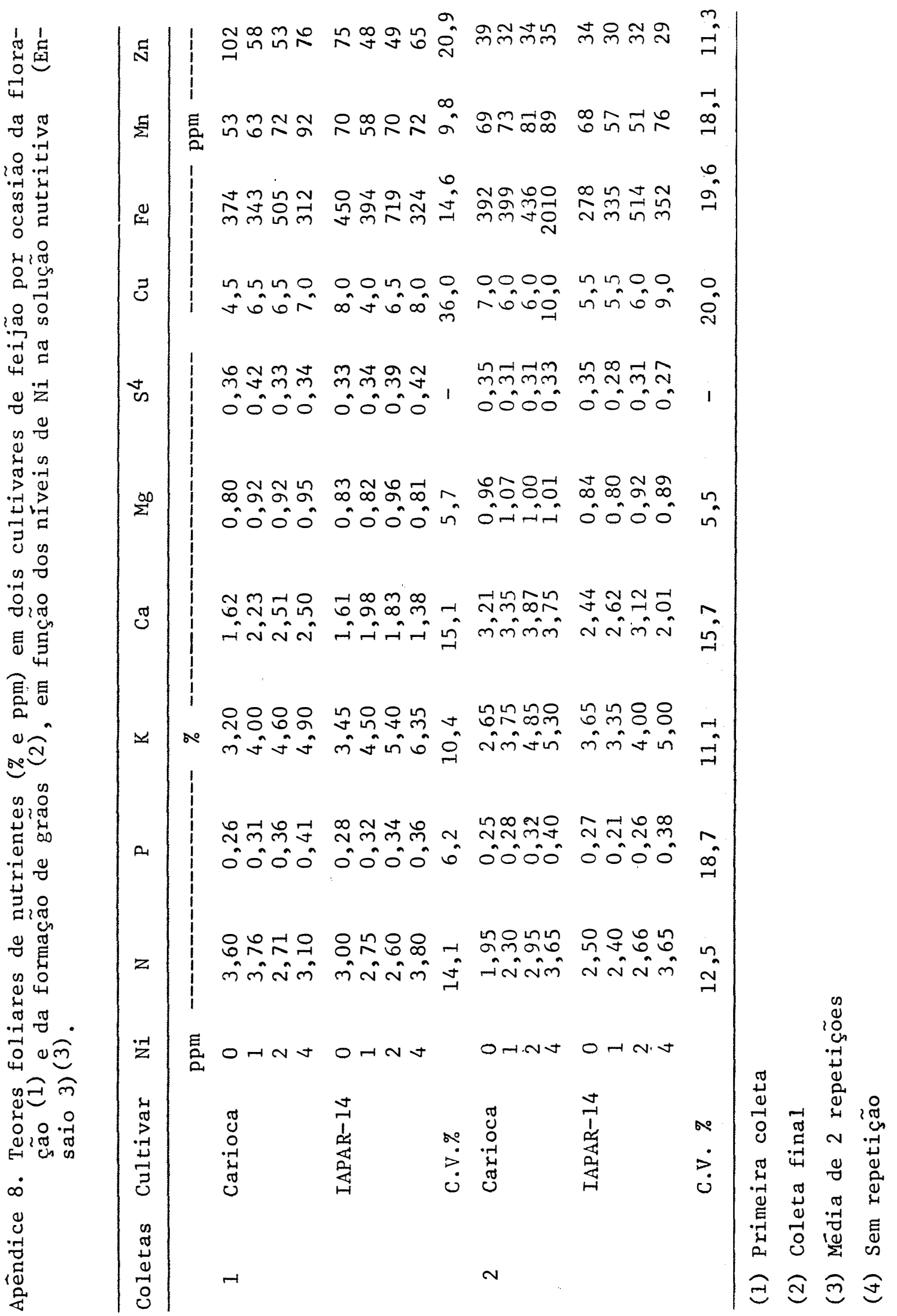


Apêndice 9. Teores de níquel em dois cultivares de feijão por ocasião da floração e da formação de grãos, em função dos níveis de níquel na solução nutritiva (Ensaio 3$)^{1}$

\begin{tabular}{|c|c|c|c|c|c|c|c|c|c|}
\hline \multirow{2}{*}{ Cultivar } & \multirow{2}{*}{$\begin{array}{r}\mathrm{Ni} \\
\mathrm{ppm}\end{array}$} & \multicolumn{2}{|c|}{ Primeira } & Coleta & \multicolumn{5}{|c|}{ Coleta Final } \\
\hline & & Folha & $\begin{array}{l}\text { Caule + } \\
\text { Ramo }\end{array}$ & Raiz & Folha & $\begin{array}{l}\text { Caule + } \\
\text { Ramo }\end{array}$ & Raiz & Casca & Grão \\
\hline \multirow[t]{4}{*}{ Carioca } & 0 & $5 d$ & $10 \mathrm{c}$ & 21 & 18 & $2 c$ & 4 & 6 & 1 \\
\hline & 1 & $43 c$ & $63 c$ & 286 & 47 & $70 \mathrm{bc}$ & 262 & 81 & 112 \\
\hline & 2 & $126 \mathrm{~b}$ & $142 \mathrm{~b}$ & 1117 & 112 & $142 \mathrm{~b}$ & 1007 & 182 & - \\
\hline & 4 & 342 a & 518 a & 1780 & 312 & 558 a & 1750 & - & - \\
\hline \multirow[t]{4}{*}{ IAPAR-14 } & 0 & $8 c$ & $7 c$ & 11 & 10 & $7 \mathrm{c}$ & 20 & 10 & 2 \\
\hline & 1 & $36 c$ & $53 \mathrm{bc}$ & 282 & 46 & $56 \mathrm{bc}$ & 207 & 97 & 112 \\
\hline & 2 & $98 \mathrm{~b}$ & $91 \mathrm{~b}$ & 702 & 92 & $122 \mathrm{~b}$ & 850 & 153 & 122 \\
\hline & 4 & 302 a & $226 a$ & 2025 & 312 & 292 a & 2860 & - & - \\
\hline $\mathrm{DMS}_{\mathrm{AxB}}^{2}$ & 5\%) & 29 & 58 & ns & ns & 85 & ns & - & - \\
\hline C.V. $\%$ & & 7,4 & 12,6 & 33,7 & 26,8 & 16,5 & 32,8 & - & - \\
\hline
\end{tabular}

(1) Mëdia de 2 repetições

(2) Comparação de médias pelo teste de Tukey, da interação níveis de Ni $x$ cultivares.

(ns) Não significativo 
Apêndice 10. Equações de regressão entre produção de matéria seca (g/va so) e teor de clorofila total na folha ( $\mu g / g$ matéria fresca) de arroz (Y), e ppm de níquel (X) na solução nutritiva (Ensaio 4).

\begin{tabular}{|c|c|c|c|c|c|}
\hline$V A R$ & $I \bar{A} \quad V \quad E$ & L & EQUAÇÃO DE REGRESSÃO & $\mathrm{R}^{2}$ & F \\
\hline Coleta & Parte & Variedade & & & \\
\hline \multirow[t]{3}{*}{1} & \multirow{2}{*}{$\begin{array}{l}\text { Colmo + } \\
\text { Perfilho }\end{array}$} & IAC- 165 & $Y=9,263-0,561 X$ & 0,99 & $* *$ \\
\hline & & IAC-4440 & $Y=6,942+0,095 X-0,047 X^{2}$ & 0,98 & $* *$ \\
\hline & Total & - & $Y=22,935-0,335 X-0,094 X^{2}$ & 0,98 & $* *$ \\
\hline \multirow[t]{9}{*}{2} & \multirow[t]{2}{*}{ Folha } & IAC- 165 & $Y=7,986+0,146 x-0,043 x^{2}$ & 0,98 & $*$ \\
\hline & & IAC -4440 & $Y=12,357-0,692 X$ & 0,99 & $* *$ \\
\hline & \multirow{2}{*}{$\begin{array}{l}\text { Colmo + } \\
\text { Perfilho }\end{array}$} & IAC- 165 & $Y=22,183-1,061 X$ & 0,96 & $* *$ \\
\hline & & IAC -4440 & $Y=35,499-2,199 X$ & 0,98 & $* *$ \\
\hline & \multirow[t]{2}{*}{ Raiz } & IAC- 165 & $Y=7,663+0,138 X-0,051 X^{2}$ & $0 ., 99$ & $* *$ \\
\hline & & IAC-4440 & $Y=8,63-0,606 x$ & 0,98 & $* *$ \\
\hline & \multirow[t]{2}{*}{ Total } & IAC -165 & $Y=43,025+0,42 X-0,235 x^{2}$ & 0,99 & $* *$ \\
\hline & & IAC -4440 & $Y=56,127-1,126 X-0,205 X^{2}$ & 0,99 & $* *$ \\
\hline & Tota1 & - & $Y=49,576-0,353 X-0,220 X^{2}$ & 0,99 & $* *$ \\
\hline \multirow{3}{*}{\multicolumn{2}{|c|}{ Clorofila }} & IAC- 165 & $Y=2374,73-383,82 X+19,125 X^{2}$ & 0,96 & $* *$ \\
\hline & & IAC -4440 & $Y=3185,27-385,10 X+14,521 X^{2}$ & 0,98 & $* *$ \\
\hline & & - & $Y=2780-384,458 X+16,823 x^{2}$ & 0,97 & $* *$ \\
\hline
\end{tabular}

(**) Significativo ao nível de $1 \%$

(*) Significativo ao nível de $5 \%$ 
Apêndice 11. Equações de regressão entre teores de nutrientes e níquel (\% e ppm) em arroz (Y), e ppm de níquel (X) na solução nutritiva (Ensaio 4).

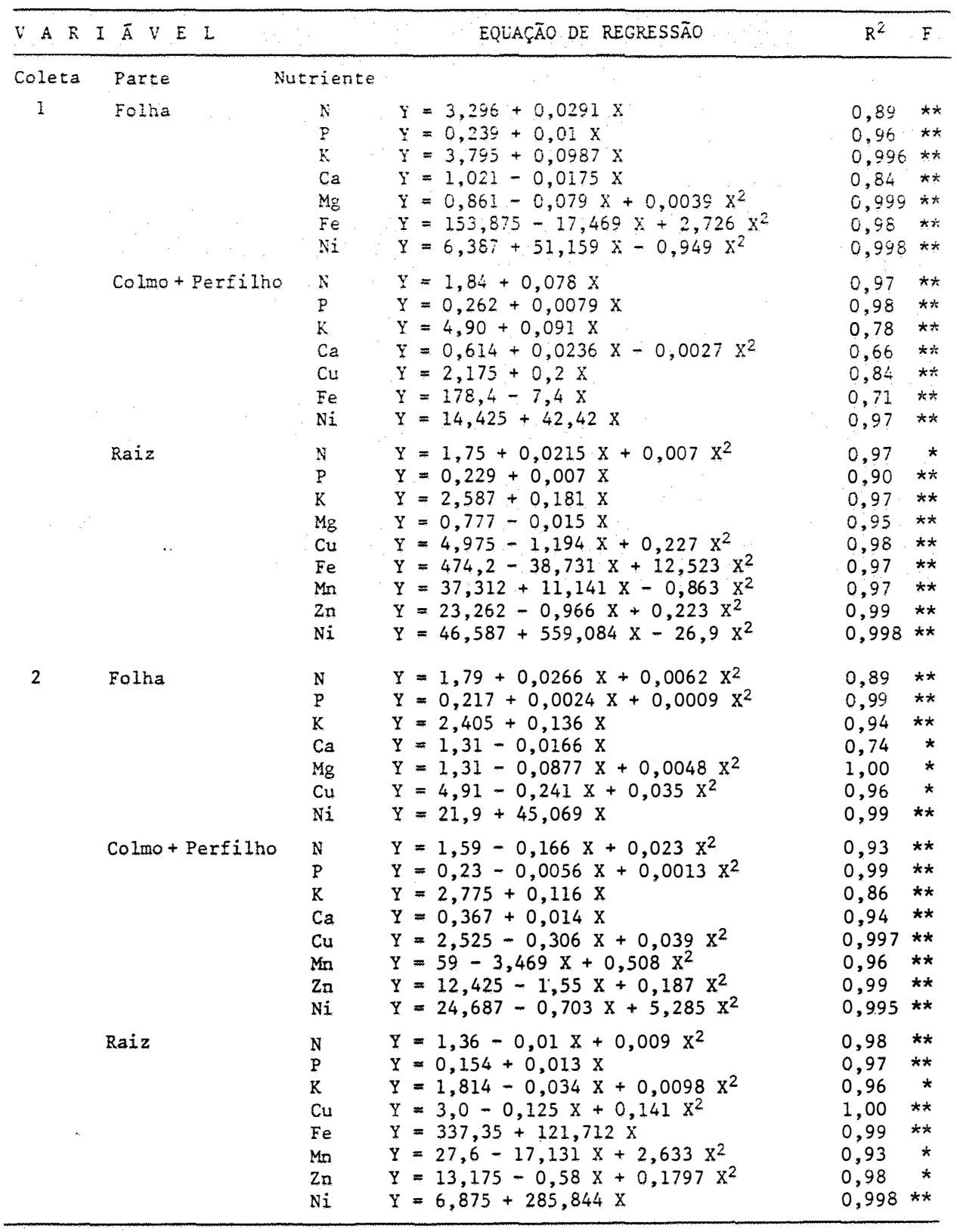

(**) Significativo ao nivel de $1 \%$

(*) Significativo ao nível de $5 \%$ 


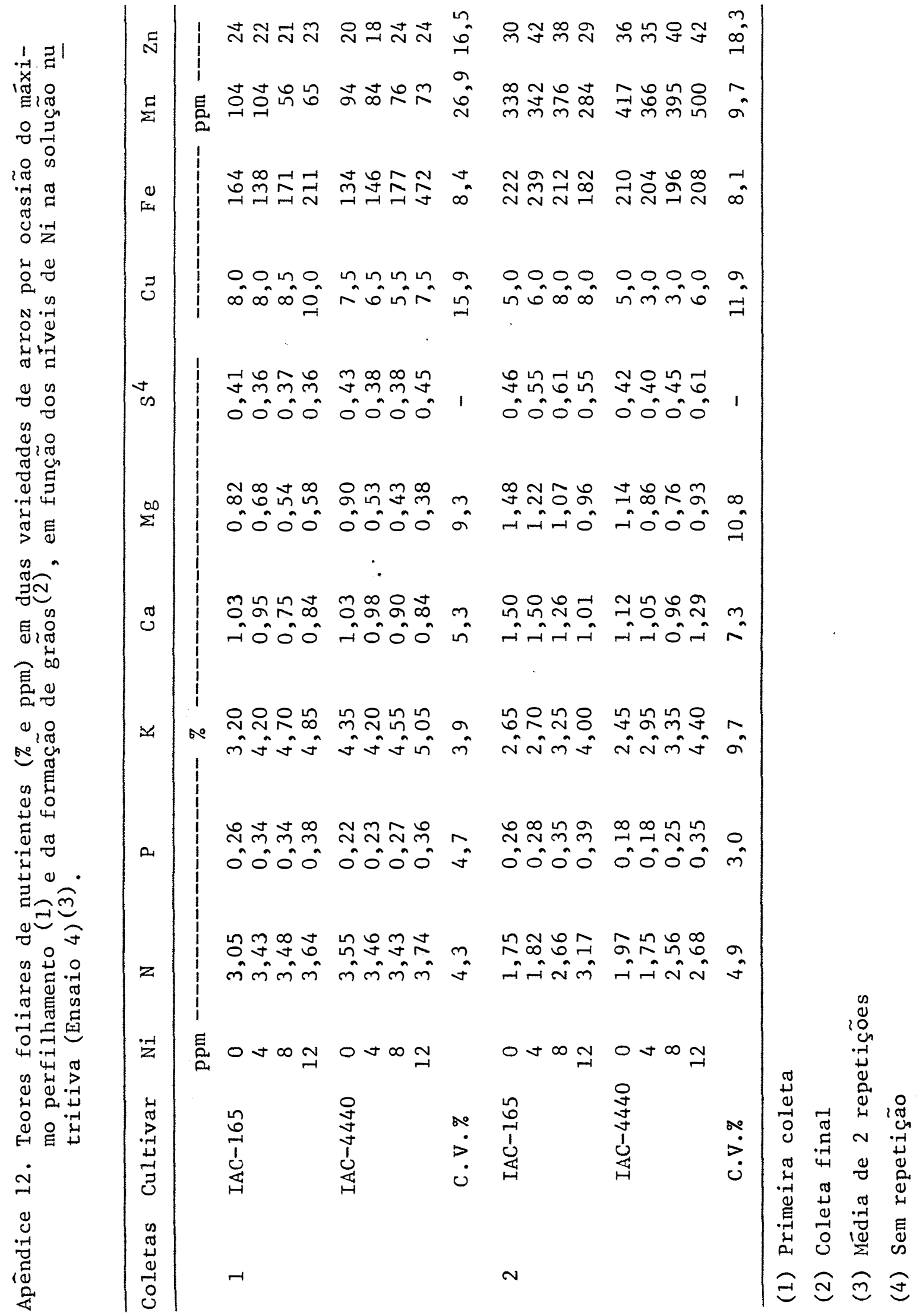


Apêndice 13. Teores de níquel em duas variedades de arroz por ocasião do māximo perfilhamento e da formação de grãos, em função dos níveis de níquel na solução nutritiva (Ensaio 4$)^{1}$.

\begin{tabular}{|c|c|c|c|c|c|c|c|c|c|}
\hline \multirow{3}{*}{ Cultivar } & \multirow{3}{*}{$\begin{array}{r}\mathrm{Ni} \\
\mathrm{ppm}\end{array}$} & \multicolumn{3}{|c|}{ Primeira Coleta } & \multicolumn{5}{|c|}{ Coleta Final } \\
\hline & & Folha & $\begin{array}{l}\text { Colmo + } \\
\text { Perfilho }\end{array}$ & Raiz & \multirow{2}{*}{$\begin{array}{l}\text { Folha } \\
\text { ppm }\end{array}$} & $\begin{array}{c}\text { Colmo + } \\
\text { Perfilho }\end{array}$ & \multirow[t]{2}{*}{ Raiz } & \multirow[t]{2}{*}{ Raquis } & \multirow[t]{2}{*}{ Grão } \\
\hline & & & & & & 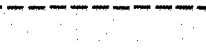 & & & \\
\hline \multirow[t]{4}{*}{ IAC- 165} & 0 & $1 \mathrm{~d}$ & 6 & 24 & $27 \mathrm{~d}$ & 13 & 55 & 38 & 35 \\
\hline & 4 & $266 c$ & 212 & 2030 & $269 c$ & 124 & 1067 & 130 & 67 \\
\hline & 8 & $401 \mathrm{~b}$ & 292 & 2595 & $437 \mathrm{~b}$ & 247 & 2045 & 185 & 104 \\
\hline & 12 & $532 a$ & 522 & 2910 & $674 a$ & 720 & 2800 & - & - \\
\hline \multirow[t]{4}{*}{ IAC -4440} & 0 & $6 \mathrm{~d}$ & 11 & 27 & $31 \mathrm{c}$ & 18 & 48 & 40 & - \\
\hline & 4 & $142 \mathrm{c}$ & 227 & 1800 & $140 \mathrm{c}$ & 144 & 1070 & 82 & 88 \\
\hline & 8 & $292 b$ & 311 & 2875 & $275 b$ & 412 & 2600 & 131 & 106 \\
\hline & 12 & $442 a$ & 572 & 2895 & $484 a$ & 852 & 4090 & - & - \\
\hline \multicolumn{2}{|c|}{$\mathrm{DMS}_{\mathrm{AxB}}^{2}(5 \%)$} & 31 & ns & ns & 132 & ns & ns & - & - \\
\hline \multicolumn{2}{|c|}{ C.V. \% } & 3,6 & 13,5 & 14,0 & 13,7 & 15,2 & 17,7 & - & - \\
\hline
\end{tabular}

(1) Média de 2 repetições

(2) Comparação de médias pelo teste de Tukey, da interação níveis de $\mathrm{Ni} \mathrm{x}$ variedades.

(ns) Não significativo 
Apêndice 14. Equações de regressão entre produção de matéria seca (g/vaso) do feijoeiro (Y), e ppm de níquel (X) em três solos ácidos (Ensaio 5).

\begin{tabular}{|c|c|c|c|c|}
\hline \multicolumn{2}{|c|}{$\mathrm{VAR} I \bar{A} V \mathrm{EL}$} & EQUAÇÃO DE REGRESSÃO & \multirow[t]{2}{*}{$\mathrm{R}^{2}$} & \multirow[t]{2}{*}{$\mathrm{F}$} \\
\hline Parte & Solos & & & \\
\hline \multirow[t]{3}{*}{ Folha } & $\mathrm{V}$ & $Y=6,533+0,017 X-0,00015 X^{2}$ & 0,87 & $* *$ \\
\hline & LRd & $Y=3,342-0,007 X-0,00008 x^{2}$ & 0,99 & $* *$ \\
\hline & $\mathrm{TE}$ & $Y=3,237-0,040 X+0,00012 X^{2}$ & 0,99 & $* *$ \\
\hline \multirow{3}{*}{$\begin{array}{l}\text { Caule + } \\
\text { Ramo }\end{array}$} & $\mathrm{V}$ & $Y=4,038-0,0008 X+0,00006 X^{2}$ & 0,98 & $* *$ \\
\hline & LRd & $Y=1,86+0,0098 X-0,0001 x^{2}$ & 0,999 & $* *$ \\
\hline & $\mathrm{TE}$ & $Y=1,57+0,0001 X-0,000099 x^{2}$ & 0,97 & $* *$ \\
\hline \multirow[t]{3}{*}{ Raiz } & $\mathrm{V}$ & $Y=3,94+0,033 X-0,00019 X^{2}$ & 0,97 & $* *$ \\
\hline & LRd & $Y=1,23+0,019 X-0,00019 X^{2}$ & 0,999 & $* *$ \\
\hline & $\mathrm{TE}$ & $Y=1,75-0,0021 X-0,0001 X^{2}$ & 0,90 & * \\
\hline \multirow[t]{3}{*}{ Grão } & $\mathrm{V}$ & $Y=5,31+0,044 X-0,0006 X^{2}$ & 0,97 & $* *$ \\
\hline & LRd & $Y=5,662-0,048 X$ & 0,97 & $* *$ \\
\hline & $\mathrm{TE}$ & $Y=1,58-0,039 X+0,0002 X^{2}$ & 1,00 & $* *$ \\
\hline \multirow[t]{3}{*}{ Casca. } & $\mathrm{V}$ & $Y=2,37+0,0076 X-0,00008 X^{2}$ & 0,46 & $* *$ \\
\hline & LRd & $Y=1,16+0,006 X-0,0001 X^{2}$ & 0,997 & $* *$ \\
\hline & $\mathrm{TE}$ & $Y=1,06-0,0038 X-0,00004 x^{2}$ & 0,98 & * \\
\hline \multirow[t]{3}{*}{ Total } & $\mathrm{V}$ & $Y=22,19+0,101 X-0,00099 X^{2}$ & 0,98 & $* *$ \\
\hline & LRd & $Y=13,32-0,025 X-0,0005 X^{2}$ & 0,995 & $* *$ \\
\hline & $\mathrm{TE}$ & $Y=9,01-0,073 X$ & 0,98 & $* *$ \\
\hline Total & - & $Y=14,9-0,0032 X-0,00045 X^{2}$ & 0,998 & $* *$ \\
\hline
\end{tabular}

(**) Significativo ao nível de $1 \%$

(*) Significativo ao nível de $5 \%$ 
Apêndice 15. Equações de regressão entre teores de nutrientes e níquel (\% e ppm) em feijoeiro ( $Y$ ), e ppm de níquel (X) em três solos ácidos (Ensaio 5).

V A R I A V E L

EQUAÇÃO DE REGRESSÃO

$R^{2} \quad F$

Parte

Nutriente

Folha

$\mathrm{N}$

$Y=1,63+0,0114 X-0,00005 X^{2}$

$0,98 *$

$\mathrm{P}$

$\mathrm{Y}=0,093+0,00037 \mathrm{X}$

$0,93 * *$

K

$Y=1,68+0,017 X-0,00007 X^{2}$

$0,99 *$

$\mathrm{Ca}$

$Y=3,98+0,026 x-0,00024 X^{2}$

$0,91 * *$

Mn

$Y=740,6-7,338 X+0,024 X^{2}$

0,97 *

$\mathrm{Zn}$

$Y=36,2-0,069 X$

$0,69 *$

$\mathrm{Ni}$

$Y=18,567+2,222 X$

$0,998 * *$

Caule + Ramo

$\mathrm{N}$

$\mathrm{Y}=0,933+0,0053 \mathrm{X}$

$0,97 * *$

$\mathrm{Ca}$

$Y=1,40+0,0029 X-0,000049 X^{2}$

$0,98 * *$

$\mathrm{Mg}$

$Y=0,925+0,0022 X-0,000013 X^{2}$

$0,995 *$

$\mathrm{Fe}$

$\mathrm{Y}=235,71-1,542 \mathrm{X}+0,0257 \mathrm{X}^{2}$

$0,91 * *$

Mn

$Y=190,8-1,441 X$

$0,72 * *$

$\mathrm{Zn}$

$Y=30,51-0,232 X+0,0016 X^{2}$

0,86

$\mathrm{Y}=19,8+2,394 \mathrm{X}$

$0,99 * *$

Raiz

$\mathrm{Ni}$

$Y=1,71+0,0064 X$

$0,96 * *$

N

$Y=0,121-0,00019 X+0,000002 X^{2}$

$0,62 *$

K

$Y=0,19+0,00067 X+0,000018 X^{2}$

0,98

$\mathrm{Cu}$

$\mathrm{Y}=47,226+0,243 \mathrm{X}-0,0022 \mathrm{X}^{2}$

$0,999 * *$

$\mathrm{Fe}$

$Y=17809,3+61,834 X-0,69 X^{2}$

$0,99 *$

$\mathrm{zn}$

$Y=87,39-1,403 X+0,0105 X^{2}$

$0,90 * *$

$\mathrm{Ni}$

$Y=54,28-0,309 X+0,048 X^{2}$

$0,99 * *$

(**) Significativo ao nível de $1 \%$

(*) Significativo ao nível de $5 \%$ 
Apêndice 16. Teores foliares de nutrientes (\% e ppm) em feijão cultivar Carioca, em função dos níveis de $\mathrm{Ni}$ em três solos äcidos (Ensaio 5) ${ }^{1}$.

\begin{tabular}{|c|c|c|c|c|c|c|c|c|c|c|c|}
\hline Solos & $\mathrm{Ni}$ & $\mathrm{N}$ & $P$ & $\mathrm{~K}$ & $\mathrm{Ca}$ & $\mathrm{Mg}$ & $s^{2}$ & $\mathrm{Cu}$ & $\mathrm{Fe}$ & $\mathrm{Mn}$ & $\mathrm{Zn}$ \\
\hline & ppm & $-\cdots$ & $\cdots-$ & $-\%--$ & $-\cdots$ & $-\cdots$ & $-\cdots$ & $-\cdots$ & - ppm - & $-\cdots$ & --- \\
\hline \multirow[t]{4}{*}{ V } & 0 & 1,84 & 0,17 & 1,05 & 4,19 & 1,00 & 0,15 & 8 & 729 & 180 & 48 \\
\hline & 30 & 1,78 & 0,17 & 0,65 & 5,12 & 1,00 & 0,16 & 8 & 1296 & 220 & 38 \\
\hline & 60 & 2,10 & 0,18 & 0,60 & 5,81 & 0,92 & 0,17 & 8 & 1424 & 245 & 36 \\
\hline & 120 & 2,01 & 0,20 & 0,70 & 4,57 & 0,94 & 0,19 & 7 & 848 & 166 & 26 \\
\hline \multirow[t]{4}{*}{ LRd } & 0 & 1,47 & 0,04 & 2,05 & 3,97 & 0,97 & 0,23 & 7 & 1273 & 527 & 27 \\
\hline & 30 & 1,80 & 0,04 & 3,10 & 3,85 & 0,92 & 0,27 & 8 & 1292 & 444 & 31 \\
\hline & 60 & 1,98 & 0,05 & 3,75 & 4,10 & 0,96 & 0,21 & 9 & 926 & 482 & 39 \\
\hline & 120 & 2,73 & 0,06 & 4,50 & 3,30 & 1,00 & 0,25 & 8 & 1775 & 374 & 28 \\
\hline \multirow[t]{4}{*}{$\mathrm{TE}$} & 0 & 1,52 & 0,09 & 1,90 & 4,00 & 1,29 & 0,24 & 6 & 673 & $1460^{\circ}$ & 33 \\
\hline & 30 & 2,38 & 0,08 & 2,80 & 4,08 & 1,38 & 0,29 & 7 & 826 & 1110 & 27 \\
\hline & 60 & 2,22 & 0,10 & 2,95 & 4,55 & 1,28 & 0,30 & 8 & 1136 & 327 & 31 \\
\hline & 120 & 2,22 & 0,16 & 3,12 & 3,00 & 1,25 & 0,32 & 9 & 1816 & 110 & 26 \\
\hline C.V.\% & & 7,4 & 21,9 & 8,7 & 8,1 & 5,0 & - & 13,2 & 34,6 & 14,0 & 15,6 \\
\hline
\end{tabular}

(1) Média de 2 repetições

(2) Sem repetição 
Apêndice 17. Teores de níquel em feijão cultivar Carioca, em função dos níveis de níquel em três solos äcidos (Ensaio 5) ${ }^{1}$.

\begin{tabular}{|c|c|c|c|c|c|c|}
\hline Solos & $\mathrm{Ni}$ & Folha & $\begin{array}{l}\text { Caule + } \\
\text { Ramo }\end{array}$ & Raiz & Casca & Grão \\
\hline & $\mathrm{ppm}$ & $\cdots$ & $--\cdots--\cdots$ & $-\quad \mathrm{ppm}$ & $\cdots-\cdots$ & $-\cdots$ \\
\hline \multirow[t]{4}{*}{ V } & 0 & $22 \mathrm{~b}$ & $22 \mathrm{~b}$ & $36 \mathrm{~d}$ & 21 & 0 \\
\hline & 30 & 92 a & $55 a b$ & $100 \mathrm{c}$ & 56 & 42 \\
\hline & 60 & 112 a & $101 \mathrm{ab}$ & $164 \mathrm{~b}$ & 84 & 61 \\
\hline & 120 & $105 \mathrm{a}$ & 106 a & $268 a$ & 148 & 97 \\
\hline \multirow[t]{4}{*}{ LRd } & 0 & $24 c$ & $28 \mathrm{~b}$ & $33 \mathrm{~d}$ & 21 & 0 \\
\hline & 30 & $78 \mathrm{~b}$ & $98 a b$ & $112 \mathrm{c}$ & 66 & 48 \\
\hline & 60 & $100 \mathrm{~b}$ & 138 a & $186 \mathrm{~b}$ & 112 & 84 \\
\hline & 120 & 298 a & $217 a$ & $593 a$ & 181 & - \\
\hline \multirow[t]{4}{*}{$\mathrm{TE}$} & 0 & $13 \mathrm{~d}$ & $12 \mathrm{c}$ & $42 c$ & 18 & 15 \\
\hline & 30 & $96 c$ & $161 \mathrm{~b}$ & $189 \mathrm{~b}$ & 140 & 97 \\
\hline & 60 & $220 \mathrm{~b}$ & $187 \mathrm{~b}$ & $360 \mathrm{~b}$ & 191 & - \\
\hline & 120 & $461 a$ & $670 \mathrm{a}$ & $1300 \mathrm{a}$ & - & - \\
\hline $\mathrm{DMS}_{\mathrm{AxB}}^{2}$ & $(5 \%)$ & 48 & 81 & 61 & - & - \\
\hline C.V. \% & & 11,7 & 18,5 & 7,6 & - & - \\
\hline
\end{tabular}

(1) Média de 2 repetições.

(2) Comparação de médias pelo teste de Tukey, da interação nĩveis de $\mathrm{Ni} \times$ solos. 
Apêndice 18. Equações de regressão entre produção de matéria seca (g/vaso) de arroz (Y), e ppm de níquel (X) em três solos ácidos (Ensaio 6).

\begin{tabular}{|c|c|c|c|c|}
\hline$V A R I \bar{A} V E L$ & & EQUAÇÃO DE REGRESSÃO & $\mathrm{R}^{2}$ & $\mathrm{~F}$ \\
\hline Parte & Solos & & & \\
\hline \multirow[t]{3}{*}{ Folha } & $\mathrm{V}$ & $Y=8,043-0,0858 x+0,00048 x^{2}$ & 0,94 & $* *$ \\
\hline & LRd & $Y=4,015-0,0104 X$ & 0,98 & $* *$ \\
\hline & $\mathrm{TE}$ & $Y=4,057-0,0198 X$ & 0,99 & $* *$ \\
\hline \multirow[t]{3}{*}{ Colmo + Perfilho } & $\mathrm{V}$ & $Y=12,49-0,104 X+0,0005 X^{2}$ & 0,998 & $* *$ \\
\hline & LRd & $Y=5,42-0,013 x$ & 0,96 & $* *$ \\
\hline & $\mathrm{TE}$ & $Y=5,904-0,026 X$ & 0,98 & $* *$ \\
\hline \multirow[t]{3}{*}{ Raiz } & $\mathrm{V}$ & $Y=9,74-0,05 X+0,00024 X^{2}$ & 0,99 & * \\
\hline & LRd & $Y=4,708-0,0048 X$ & 0,60 & ns \\
\hline & $\mathrm{TE}$ & $Y=4,86+0,0095 X-0,00022 X^{2}$ & 0,996 & * \\
\hline \multirow[t]{3}{*}{ Grão } & $\mathrm{V}$ & $Y=3,404-0,0541 X+0,00029 X^{2}$ & 0,95 & $* *$ \\
\hline & LRd & $Y=1,86-0,0283 X+0,00017 X^{2}$ & 1,00 & $* *$ \\
\hline & $\mathrm{TE}$ & $Y=2,08+0,0008 x-0,00014 x^{2}$ & 0,96 & $* *$ \\
\hline \multirow[t]{3}{*}{ Total } & $\mathrm{V}$ & $Y=35,298-0,296 X+0,0015 X^{2}$ & 0,999 & $* *$ \\
\hline & LRd & $Y=16,497-0,0384 X$ & 0,98 & $* *$ \\
\hline & $\mathrm{TE}$ & $Y=17,43-0,0199 X-0,00053 X^{2}$ & 0,999 & $* *$ \\
\hline Total & - & $Y=23,155-0,124 X+0,00037 x^{2}$ & 0,999 & $* *$ \\
\hline
\end{tabular}

(**) Significativo ao nível de $1 \%$

(*) Significativo ao nível de $5 \%$

(ns) Não significativo 
Apêndice 19. Equações de regressão entre teores de nutrientes e níquel (\% e ppm) em arroz (Y), e ppm de níquel (X) em três solos äcidos (Ensaio 6).

\begin{tabular}{|c|c|c|c|c|}
\hline$V A, R I \bar{A} V E L$ & & EQUAÇÃO DE REGRESSÃO & $R^{2}$ & F \\
\hline Parte & Nutriente & & & \\
\hline \multirow[t]{6}{*}{ Folha } & $\mathrm{K}$ & $Y=2,08+0,023 X-0,00011 X^{2}$ & 0,997 & $* *$ \\
\hline & $\mathrm{Ca}$ & $Y=1,398+0,0033 X-0,000047 X^{2}$ & 0,99 & $* *$ \\
\hline & $\mathrm{Mg}$ & $Y=1,588-0,0033 X$ & 0,94 & $* *$ \\
\hline & Mn & $Y=2617,23-15,954 X$ & 0,99 & $* *$ \\
\hline & $\mathrm{Zn}$ & $Y=50,267-0,146 X$ & 0,92 & $\nLeftarrow *$ \\
\hline & $\mathrm{Ni}$ & $Y=15,23+1,494 X-0,0043 x^{2}$ & 0,99 & $* *$ \\
\hline \multirow[t]{7}{*}{ Colmo + Perfilho } & $\mathrm{N}$ & $Y=0,52+0,0015 X$ & 0,90 & $* *$ \\
\hline & $\mathrm{K}$ & $Y=3,06+0,0062 X$ & 0,90 & $* *$ \\
\hline & $\mathrm{Ca}$ & $Y=0,56-0,00112 X$ & 0,91 & $* *$ \\
\hline & $\mathrm{Mg}$ & $Y=1,12-0,0024 X$ & 0,86 & $* *$ \\
\hline & $\mathrm{Mn}$ & $Y=600,47-2,591 X$ & 0,91 & $* *$ \\
\hline & $\mathrm{Zn}$ & $Y=204,67-1,040 X$ & 0,93 & $* *$ \\
\hline & $\mathrm{Ni}$ & $Y=10,32+1,874 X-0,0066 x^{2}$ & 0,999 & $* *$ \\
\hline \multirow[t]{3}{*}{ Raiz } & $\mathrm{K}$ & $Y=0,387+0,0022 X$ & 0,87 & $* *$ \\
\hline & $\mathrm{Zn}$ & $Y=92,97-0,364 X$ & 0,82 & $* *$ \\
\hline & $\mathrm{Ni}$ & $Y=31,1+2,708 X$ & 0,999 & $* *$ \\
\hline
\end{tabular}

(**) Significativo ao nível de $1 \%$ 
Apêndice 20. Teores foliares de nutrientes (\% e ppm) em arroz variedade IAC-165, em função dos níveis de $\mathrm{Ni}$ em três solos ácidos (Ensaio 6) ${ }^{1}$.

\begin{tabular}{|c|c|c|c|c|c|c|c|c|c|c|c|}
\hline Solos & $\mathrm{Ni}$ & $\mathrm{N}$ & $P$ & $\mathrm{~K}$ & $\mathrm{Ca}$ & $\mathrm{Mg}$ & $s^{2}$ & $\mathrm{Cu}$ & $\mathrm{Fe}$ & Mn & $\mathrm{Zn}$ \\
\hline & $\mathrm{ppm}$ & $\cdots$ & $-\cdots$ & $\%$ & $-\cdots$ & --- & ----- & $-\cdots p$ & ppm - & ----- & $-\cdots$ \\
\hline \multirow[t]{4}{*}{ V } & 0 & 0,91 & 0,23 & 1,00 & 1,62 & 1,69 & 0,30 & 8 & 402 & 880 & 59 \\
\hline & 30 & 1,05 & 0,25 & 2,30 & 1,64 & 1,64 & 0,34 & 8 & 382 & 1555 & 61 \\
\hline & 60 & 0,88 & 0,25 & 2,90 & 1,54 & 1,42 & 0,30 & 8 & 387 & 830 & 61 \\
\hline & 120 & 1,05 & 0,22 & 3,00 & 1,22 & 1,41 & 0,28 & 10 & 375 & 616 & 41 \\
\hline \multirow[t]{4}{*}{ LRd } & 0 & 1,19 & 0,07 & 3,30 & 0,93 & 1,40 & 0,22 & 10 & 304 & 1900 & 36 \\
\hline & 30 & 0,96 & 0,08 & 3,20 & 1,09 & 1,44 & 0,30 & 9 & 338 & 1705 & 38 \\
\hline & 60 & 1,22 & 0,08 & 3,65 & 1,24 & 1,33 & 0,34 & 9 & 367 & 1105 & 28 \\
\hline & 120 & 0,80 & 0,07 & 3,60 & 1,12 & 1,14 & 0,33 & 6 & 348 & 920 & 24 \\
\hline \multirow[t]{4}{*}{$\mathrm{TE}$} & 0 & 0,98 & 0,08 & 1,90 & 1,67 & 1,54 & 0,30 & 10 & 289 & 4880 & 48 \\
\hline & 30 & 1,07 & 0,07 & 2,60 & 1,56 & 1,56 & 0,44 & 11 & 357 & 3435 & 42 \\
\hline & 60 & 0,94 & 0,06 & 2,55 & 1,55 & 1,42 & 0,43 & 12 & 393 & 3010 & 42 \\
\hline & 120 & 1,05 & 0,05 & 3,10 & 1,00 & 0,96 & 0,33 & 14 & 300 & 520 & 28 \\
\hline C.V.\% & & 13,9 & 22,2 & 6,4 & 6,9 & 8,5 & - & 16,0 & 13,1 & 20,6 & 12,6 \\
\hline
\end{tabular}

(1) Média de 2 repetições

(2) Sem repetição 
Apêndice 21. Teores de níquel em arroz variedade IAC-165, em função dos níveis de níquel em três solos ácidos (Ensaio 6) ${ }^{1}$.

\begin{tabular}{|c|c|c|c|c|c|c|}
\hline Solos & $\mathrm{Ni}$ & Folha & $\begin{array}{l}\text { Colmo + } \\
\text { Perfilho }\end{array}$ & Raiz & Raquis & Grão \\
\hline & $\mathrm{ppm}$ & $-\cdots-\cdots$ & ppm & $\cdots$ & $-\cdots-\cdots$ & $-\ldots-$ \\
\hline \multirow[t]{4}{*}{ V } & 0 & $18 \mathrm{~b}$ & $7 \mathrm{c}$ & $24 \mathrm{~b}$ & 23 & 12 \\
\hline & 30 & $35 \mathrm{~b}$ & $36 \mathrm{bc}$ & $69 \mathrm{~b}$ & 26 & 27 \\
\hline & 60 & $46 a b$ & $56 a b$ & $124 a b$ & 41 & 48 \\
\hline & 120 & 69 a & $90 \mathrm{a}$ & $190 \mathrm{a}$ & 48 & 41 \\
\hline \multirow[t]{4}{*}{ LRd } & 0 & $21 \mathrm{c}$ & $10 \mathrm{c}$ & $33 c$ & 29 & 20 \\
\hline & 30 & $52 \mathrm{~b}$ & $55 \mathrm{~b}$ & $141 \mathrm{~b}$ & 62 & 42 \\
\hline & 60 & $80 \mathrm{~b}$ & $78 \mathrm{~b}$ & $188 \mathrm{~b}$ & 113 & 46 \\
\hline & 120 & 114 a & 146 a & $423 a$ & 105 & 79 \\
\hline \multirow[t]{4}{*}{$\mathrm{TE}$} & 0 & $12 \mathrm{~d}$ & $12 c$ & $24 \mathrm{~d}$ & 33 & 17 \\
\hline & 30 & $66 \mathrm{c}$ & $96 \mathrm{~b}$ & $141 \mathrm{c}$ & 75 & 72 \\
\hline & 60 & $153 \mathrm{~b}$ & 158 a & $271 b$ & 145 & 91 \\
\hline & 120 & 211 a & $186 a$ & $450 a$ & 111 & 106 \\
\hline $\mathrm{DMS}_{\mathrm{AxB}}^{2}$ & $(5 \%)$ & 31 & 44 & 103 & - & - \\
\hline C.V. \% & & 13,9 & 18,6 & 19,7 & - & - \\
\hline
\end{tabular}

(1) Média de 2 repetições

(2) Comparação de médias pelo teste de Tukey, da interação níveis de $\mathrm{Ni} \times$ solos. 
Apêndice 22. Equações de regressão entre produção de matéria seca (g/vaso) de feijoeiro (Y), e ppm de níquel (X) em dois solos áci dos com e sem calagem (Ensaio 7).

\begin{tabular}{|c|c|c|c|c|c|}
\hline $\begin{array}{llll}V & A & R & ]\end{array}$ & $I \bar{A} V E$ & $\mathrm{~L}$ & EQUAÇÃO DE REGRESSÃO & $\mathrm{R}^{2}$ & $F$ \\
\hline $\begin{array}{l}\text { Parte } \\
\text { Folha }\end{array}$ & $\begin{array}{l}\text { Calagem } \\
+ \\
+\end{array}$ & $\begin{array}{l}\text { Solos } \\
\text { LRd } \\
\text { TE } \\
\text { LRd } \\
\text { TE }\end{array}$ & $\begin{array}{l}Y=3,34-0,0071 X-0,000083 X^{2} \\
Y=3,24-0,0405 X+0,00012 X^{2} \\
Y=4,43-0,0106 X \\
Y=4,30-0,0337 X+0,000074 X^{2}\end{array}$ & $\begin{array}{l}0,99 \\
0,99 \\
0,91 \\
0,98\end{array}$ & $\begin{array}{r}* \\
* * \\
* * \\
*\end{array}$ \\
\hline $\begin{array}{l}\text { Caule + } \\
\text { Ramo }\end{array}$ & + & $\begin{array}{l}\text { LRd } \\
\text { TE } \\
\text { LRd } \\
\text { TE }\end{array}$ & $\begin{array}{l}Y=1,86+0,0098 X-0,00012 X^{2} \\
Y=1,57+0,0001 X-0,000099 X^{2} \\
Y=3,21-0,0097 X \\
Y=2,42-0,0012 X-0,00008 X^{2}\end{array}$ & $\begin{array}{l}0,999 \\
0,97 \\
0,62 \\
1,00\end{array}$ & $\begin{array}{l}* * \\
* * \\
* * \\
* *\end{array}$ \\
\hline Raiz & - & $\begin{array}{l}\text { LRd } \\
\text { TE } \\
\text { LRd } \\
\text { TE }\end{array}$ & $\begin{array}{l}\mathrm{Y}=1,23+0,0193 \mathrm{X}-0,00019 \mathrm{X}^{2} \\
\mathrm{Y}=1,75-0,0021 \mathrm{X}-0,000097 \mathrm{X}^{2} \\
\mathrm{Y}=1,45+0,0144 \mathrm{X}-0,00012 \mathrm{X}^{2} \\
\mathrm{Y}=1,552-0,0067 \mathrm{X}\end{array}$ & $\begin{array}{l}0,999 \\
0,90 \\
0,95 \\
0,91\end{array}$ & $\begin{array}{l}* * \\
* * \\
* * \\
* *\end{array}$ \\
\hline Grão & - & $\begin{array}{l}\text { LRd } \\
\text { TE } \\
\text { LRd } \\
\text { TE }\end{array}$ & $\begin{array}{l}Y=5,662-0,048 X \\
Y=1,58-0,0394 X+0,00022 X^{2} \\
Y=5,68-0,0694 X+0,00029 X^{2} \\
Y=2,12-0,0598 X+0,00035 X^{2}\end{array}$ & $\begin{array}{l}0,97 \\
1,00 \\
0,96 \\
0,97\end{array}$ & $\begin{array}{l}* * \\
* * \\
* * \\
* *\end{array}$ \\
\hline Casca & - & $\begin{array}{l}\text { LRd } \\
\text { TE } \\
\text { LRd } \\
\text { TE }\end{array}$ & $\begin{array}{l}Y=1,16+0,0061 X-0,00012 X^{2} \\
Y=1,06-0,0038 X-0,000041 X^{2} \\
Y=1,226-0,0015 X \\
Y=1,16-0,00052 X-0,000054 X^{2}\end{array}$ & $\begin{array}{l}0,997 \\
0,98 \\
0,97 \\
0,999\end{array}$ & $\begin{array}{l}* * \\
* * \\
* * \\
* *\end{array}$ \\
\hline Total & $\begin{array}{l}- \\
+\end{array}$ & $\begin{array}{l}\text { LRd } \\
\text { TE } \\
\text { LRd } \\
\text { TE }\end{array}$ & $\begin{array}{l}\mathrm{Y}=13,32-0,0247 \mathrm{X}-0,00048 \mathrm{X}^{2} \\
\mathrm{Y}=9,007-0,073 \mathrm{X} \\
\mathrm{Y}=15,685-0,0548 \mathrm{X} \\
\mathrm{Y}=11,59-0,104 \mathrm{X}+0,00031 \mathrm{X}^{2}\end{array}$ & $\begin{array}{l}0,99 \\
0,98 \\
0,89 \\
0,98\end{array}$ & $\begin{array}{l}* * \\
* * \\
* * \\
* *\end{array}$ \\
\hline Folha & $\begin{array}{l}- \\
+\end{array}$ & & $\begin{array}{l}Y=3,253-0,0213 X \\
Y=4,302-0,0176 \mathrm{X}\end{array}$ & $\begin{array}{l}0,99 \\
0,996\end{array}$ & $\begin{array}{l}* * \\
* *\end{array}$ \\
\hline $\begin{array}{l}\text { Caule + } \\
\text { Ramo }\end{array}$ & $\overline{+}$ & & $\begin{array}{l}Y=1,71+0,0049 X-0,00011 X^{2} \\
Y=2,77-0,0023 X-0,000066 X^{2}\end{array}$ & $\begin{array}{l}0,99 \\
0,90\end{array}$ & $* *$ \\
\hline Raiz & $\overline{+}+$ & & $\begin{array}{l}Y=1,49+0,0086 X-0,00014 X^{2} \\
Y=1,52+0,0027 X-0,000049 X^{2}\end{array}$ & $\begin{array}{l}0,96 \\
0,98\end{array}$ & $\begin{array}{l}* * \\
* *\end{array}$ \\
\hline Grão & 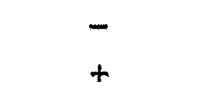 & & $\begin{array}{l}Y=3,65-0,046 X+0,00013 X^{2} \\
Y=3,90-0,0646 X+0,00032 X^{2}\end{array}$ & $\begin{array}{l}0,98 \\
0,997\end{array}$ & $\begin{array}{l}* * \\
* *\end{array}$ \\
\hline Casca & + & & $\begin{array}{l}Y=1,11+0,00115 X-0,00008 X^{2} \\
Y=1,19-0,00094 X-0,000028 X^{2}\end{array}$ & $\begin{array}{l}0,99 \\
0,999\end{array}$ & $* *$ \\
\hline Total & $\overline{+}$ & & $\begin{array}{l}Y=11,26-0,0552 X-0,00019 X^{2} \\
Y=13,74-0,086 X+0,00021 X^{2}\end{array}$ & $\begin{array}{l}0,999 \\
0,99\end{array}$ & $\begin{array}{ll}* * \\
* *\end{array}$ \\
\hline Total & & & $Y=12,48-0,069 X$ & 0,999 & $* *$ \\
\hline
\end{tabular}

(**) Significativo ao nível de $1 \%$

(*) Significativo ao níve1 de $5 \%$ 
Apêndice 23. Equações de regressão entre teores de nutrientes e níquel (\% e ppm) em feijoeiro ( $Y$ ), e ppm de níquel (X) em dois solos ácidos com e sem calagem (Ensaio 7).

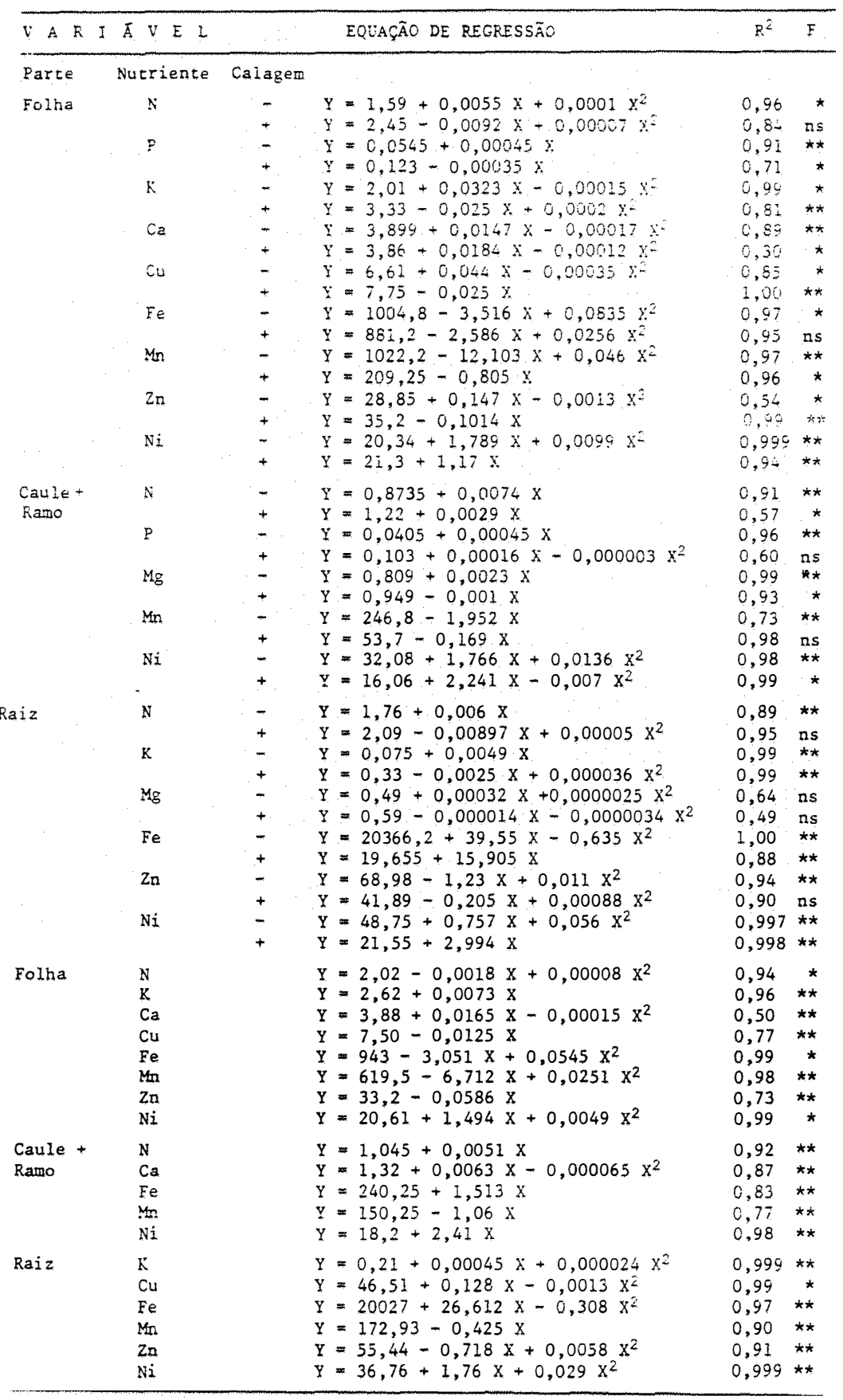

(**) Significativo ao nível de $1 \%$

(*) Significativo ao nível de $5 \%$

(ns) Não significativo 
Apêndice 24. Teores foliares de nutrientes (\% e ppm) em feijão cultivar Carioca, em função dos niveis de $\mathrm{Ni}$ e da calagem em dois so solos äcidos (Ensaio 7) 1 .

\begin{tabular}{|c|c|c|c|c|c|c|c|c|c|c|c|c|}
\hline Solos & Calagem & $\mathrm{Ni}$ & $\mathrm{N}$ & $\mathrm{P}$ & $\mathrm{K}$ & $\mathrm{Ca}$ & Mg & $s^{2}$ & $\mathrm{Cu}$ & $\mathrm{Fe}$ & $\mathrm{Mn}$ & $\mathrm{Zn}$ \\
\hline & & $\mathrm{ppm}$ & $-\cdots$ & $\cdots$ & $\%$ & $\cdots$ & - & $\cdots$ & -- & $\mathrm{ppm}$ & $-\cdots$ & -- \\
\hline \multirow[t]{2}{*}{ LRd } & - & $\begin{array}{r}0 \\
30 \\
60 \\
120\end{array}$ & $\begin{array}{l}1,47 \\
1,80 \\
1,98 \\
2,73\end{array}$ & $\begin{array}{l}0,04 \\
0,04 \\
0,05 \\
0,06\end{array}$ & $\begin{array}{l}2,05 \\
3,10 \\
3,75 \\
4,50\end{array}$ & $\begin{array}{l}3,97 \\
3,85 \\
4,10 \\
3,30\end{array}$ & $\begin{array}{l}0,97 \\
0,92 \\
0,96 \\
1,00\end{array}$ & $\begin{array}{l}0,23 \\
0,27 \\
0,21 \\
0,25\end{array}$ & $\begin{array}{l}7 \\
8 \\
9 \\
8\end{array}$ & $\begin{array}{r}1273 \\
1292 \\
926 \\
1775\end{array}$ & $\begin{array}{l}527 \\
444 \\
482 \\
374\end{array}$ & $\begin{array}{l}27 \\
31 \\
39 \\
28\end{array}$ \\
\hline & + & $\begin{array}{r}0 \\
30 \\
60 \\
120\end{array}$ & $\begin{array}{l}2,31 \\
2,41 \\
2,08 \\
2,31\end{array}$ & $\begin{array}{l}0,12 \\
0,12 \\
0,10 \\
0,06\end{array}$ & $\begin{array}{l}4,95 \\
3,05 \\
3,30 \\
3,40\end{array}$ & $\begin{array}{l}3,73 \\
3,50 \\
4,61 \\
4,52\end{array}$ & $\begin{array}{l}1,04 \\
0,91 \\
0,84 \\
0,88\end{array}$ & $\begin{array}{l}0,20 \\
0,22 \\
0,26 \\
0,21\end{array}$ & $\begin{array}{l}8 \\
8 \\
7 \\
4\end{array}$ & $\begin{array}{l}903 \\
779 \\
827 \\
738\end{array}$ & $\begin{array}{l}154 \\
136 \\
138 \\
129\end{array}$ & $\begin{array}{l}38 \\
33 \\
35 \\
22\end{array}$ \\
\hline \multirow[t]{2}{*}{$\mathrm{TE}$} & - & $\begin{array}{r}0 \\
30 \\
60 \\
120\end{array}$ & $\begin{array}{l}1,52 \\
2,38 \\
2,22 \\
4,75\end{array}$ & $\begin{array}{l}0,09 \\
0,08 \\
0,10 \\
0,16\end{array}$ & $\begin{array}{l}1,90 \\
2,80 \\
2,95 \\
3,12\end{array}$ & $\begin{array}{l}4,00 \\
4,08 \\
4,55 \\
3,00\end{array}$ & $\begin{array}{l}1,29 \\
1,38 \\
1,28 \\
1,25\end{array}$ & $\begin{array}{l}0,24 \\
0,29 \\
0,30 \\
0,32\end{array}$ & $\begin{array}{l}6 \\
7 \\
8 \\
9\end{array}$ & $\begin{array}{r}673 \\
826 \\
1136 \\
1816\end{array}$ & $\begin{array}{r}1460 \\
1110 \\
327 \\
110\end{array}$ & $\begin{array}{l}33 \\
27 \\
31 \\
26\end{array}$ \\
\hline & + & $\begin{array}{r}0 \\
30 \\
60 \\
120\end{array}$ & $\begin{array}{l}2,54 \\
2,22 \\
2,10 \\
2,34\end{array}$ & $\begin{array}{l}0,12 \\
0,14 \\
0,15 \\
0,11\end{array}$ & $\begin{array}{l}1,90 \\
2,00 \\
2,20 \\
3,10\end{array}$ & $\begin{array}{l}4,40 \\
3,99 \\
5,23 \\
3,86\end{array}$ & $\begin{array}{l}1,02 \\
1,01 \\
1,12 \\
1,10\end{array}$ & $\begin{array}{l}0,20 \\
0,20 \\
0,24 \\
0,30\end{array}$ & $\begin{array}{l}8 \\
6 \\
6 \\
5\end{array}$ & $\begin{array}{r}873 \\
840 \\
836 \\
1136\end{array}$ & $\begin{array}{l}284 \\
213 \\
176 \\
106\end{array}$ & $\begin{array}{l}34 \\
30 \\
24 \\
24\end{array}$ \\
\hline C.V. \% & & & 11,9 & 29,8 & 13,1 & 8,9 & 4,8 & - & 14,0 & 18,2 & 16,0 & 12,0 \\
\hline
\end{tabular}

(1) Mëdia de 2 repetições

(2) Sem repetição 
Apêndice 25. Teores de níquel em feijão cultivar Carioca, em função dos níveis de níquel e da calagem em dois solos äcidos (Ensaio 7) 1 .

\begin{tabular}{|c|c|c|c|c|c|c|c|}
\hline Solos & Calagem & $\mathrm{Ni}$ & Folha & $\begin{array}{l}\text { Caule + } \\
\text { Ramo }\end{array}$ & Raiz & Casca & Grão \\
\hline & & $\mathrm{ppm}$ & $-\infty-\infty$ & $\ldots-$ ppm & $-\cdots-\cdots$ & $-\cdots--$ & $-\cdots$ \\
\hline \multirow[t]{2}{*}{ LRd } & - & $\begin{array}{r}0 \\
30 \\
60 \\
120\end{array}$ & $\begin{array}{r}24 \\
78 \\
100 \\
298\end{array}$ & $\begin{array}{r}28 \mathrm{c} \\
98 \mathrm{~b} \\
138 \mathrm{~b} \\
217 \mathrm{a}\end{array}$ & $\begin{array}{r}33 \mathrm{~d} \\
112 \mathrm{c} \\
186 \mathrm{~b} \\
593 \mathrm{a}\end{array}$ & $\begin{array}{r}21 \\
66 \\
112 \\
181\end{array}$ & $\begin{array}{r}0 \\
48 \\
84 \\
-\end{array}$ \\
\hline & + & $\begin{array}{r}0 \\
30 \\
60 \\
120\end{array}$ & $\begin{array}{l}18 \\
71 \\
51 \\
99\end{array}$ & $\begin{array}{rl}16 & c \\
86 & b \\
103 & b \\
168 & a\end{array}$ & $\begin{array}{rl}32 & c \\
108 & b \\
174 & b \\
390 & a\end{array}$ & $\begin{array}{r}26 \\
77 \\
109 \\
140\end{array}$ & $\begin{array}{r}1 \\
45 \\
83 \\
102\end{array}$ \\
\hline \multirow[t]{2}{*}{$\mathrm{TE}$} & - & $\begin{array}{r}0 \\
30 \\
60 \\
120\end{array}$ & $\begin{array}{r}13 \\
96 \\
220 \\
461\end{array}$ & $\begin{array}{rl}12 & \mathrm{c} \\
161 & \mathrm{~b} \\
187 & \mathrm{~b} \\
670 & \mathrm{a}\end{array}$ & $\begin{array}{r}42 \mathrm{~d} \\
189 \mathrm{c} \\
360 \mathrm{~b} \\
1300 \mathrm{a}\end{array}$ & $\begin{array}{r}18 \\
140 \\
191 \\
-\end{array}$ & $\begin{array}{r}15 \\
97 \\
- \\
-\end{array}$ \\
\hline & + & $\begin{array}{r}0 \\
30 \\
60 \\
120\end{array}$ & $\begin{array}{r}9 \\
83 \\
102 \\
229\end{array}$ & $\begin{array}{rl}11 & d \\
81 & c \\
137 & b \\
200 & a\end{array}$ & $\begin{array}{rl}22 & d \\
96 & c \\
231 & b \\
374 & a\end{array}$ & $\begin{array}{r}16 \\
113 \\
203 \\
37\end{array}$ & $\begin{array}{r}12 \\
106 \\
- \\
-\end{array}$ \\
\hline $\mathrm{DMS}_{\mathrm{A} \times \mathrm{B}}^{2}$ & $(5 \%)$ & & ns & 47 & 70 & - & - \\
\hline C.V. \% & & & 12,4 & 11,3 & 9,1 & - & - \\
\hline
\end{tabular}

(1) Média de 2 repetições

(2) Comparação de médias pelo teste de Tukey, da interação solos x calagem $x$ nîveis de $\mathrm{Ni}$.

(ns) Não significativo 
Apêndice 26. Equações de regressão entre produção de matēria seca (g/vaso) de arroz (Y), e ppm de níquel (X) em dois solos ácidos com e sem calagem (Ensaio 8).

\begin{tabular}{|c|c|c|c|c|c|c|}
\hline$V A R I I$ & $\bar{A} \quad V \quad E \quad L$ & & & EQUAÇÃO DE REGRESSÃO & $R^{2}$ & $F$ \\
\hline Parte & Calagem & Solos & & & & \\
\hline Folha & + & $\begin{array}{l}\text { LRd } \\
\text { TE } \\
\text { LRd } \\
\text { TE }\end{array}$ & $\begin{array}{l}\mathrm{Y} \\
\mathrm{Y} \\
\mathrm{Y} \\
\mathrm{Y}\end{array}$ & $\begin{array}{l}=4,015-0,0104 x \\
=3,95-0,0125 x-0,000058 x^{2} \\
=4,155-0,0130 x \\
=4,024-0,0049 x-0,000099 x^{2}\end{array}$ & $\begin{array}{l}0,98 \\
1,00 \\
0,98 \\
0,97\end{array}$ & $\begin{array}{r}* * \\
* \\
* * \\
* *\end{array}$ \\
\hline Raiz & + & $\begin{array}{l}\text { LRd } \\
\text { TE } \\
\text { LRd } \\
\text { TE }\end{array}$ & $\begin{array}{l}\mathrm{Y} \\
\mathrm{Y} \\
\mathrm{Y} \\
\mathrm{Y}\end{array}$ & $\begin{array}{l}=4,71-0,0048 x \\
=4,86+0,0095 x-0,00022 x^{2} \\
=4,92-0,0122 x \\
=4,27-0,0047 x\end{array}$ & $\begin{array}{l}0,60 \\
0,996 \\
0,95 \\
0,91\end{array}$ & $\begin{array}{l}* * \\
* * \\
* * \\
* *\end{array}$ \\
\hline Raquis & $\begin{array}{l}- \\
+\end{array}$ & $\begin{array}{l}\text { LRd } \\
\text { TE } \\
\text { LRd } \\
\text { TE }\end{array}$ & $\begin{array}{l}\mathrm{Y} \\
\mathrm{Y} \\
\mathrm{Y} \\
\mathrm{Y}\end{array}$ & $\begin{array}{l}=0,80-0,0031 x \\
=0,83-0,0047 x \\
=0,81-0,004 x \\
=0,78-0,0065 x+0,00003 x^{2}\end{array}$ & $\begin{array}{l}0,95 \\
0,96 \\
0,93 \\
0,99\end{array}$ & $\begin{array}{l}* * \\
* * \\
* * \\
*\end{array}$ \\
\hline Grão & $\begin{array}{l}- \\
+\end{array}$ & $\begin{array}{l}\text { LRd } \\
\text { TE } \\
\text { LRd } \\
\text { TE }\end{array}$ & $\begin{array}{l}\mathrm{Y} \\
\mathrm{Y} \\
\mathrm{Y} \\
\mathrm{Y}\end{array}$ & $\begin{array}{l}=1,86-0,028 x+0,00017 x^{2} \\
=2,08+0,0008 x-0,00014 x^{2} \\
=1,22-0,00266 x \\
=2,02-0,0028 x-0,00008 x^{2}\end{array}$ & $\begin{array}{l}1,00 \\
0,96 \\
0,31 \\
0,94\end{array}$ & $\begin{array}{l}* * \\
* * \\
* \\
*\end{array}$ \\
\hline Total & $\begin{array}{l}- \\
+\end{array}$ & $\begin{array}{l}\text { LRd } \\
\text { TE } \\
\text { LRd } \\
\text { TE }\end{array}$ & $\begin{array}{l}\mathrm{Y} \\
\mathrm{Y} \\
\mathrm{Y} \\
\mathrm{Y}\end{array}$ & $\begin{array}{l}=16,497-0,038 x \\
=17,43-0,0199 x-0,00053 x^{2} \\
=16,48-0,0659 x+0,00018 x^{2} \\
=16,675-0,0584 x\end{array}$ & $\begin{array}{l}0,98 \\
0,999 \\
0,999 \\
0,999\end{array}$ & $\begin{array}{l}* * \\
* * \\
* \\
* *\end{array}$ \\
\hline $\begin{array}{l}\text { Colmo + } \\
\text { Perfilho }\end{array}$ & + & & & $\begin{array}{l}=5,53-0,0105 x-0,000074 x^{2} \\
=5,31-0,0257 x+0,000076 x^{2}\end{array}$ & $\begin{array}{l}1,00 \\
0,99\end{array}$ & * \\
\hline Raiz & $\overline{+}$ & & $\begin{array}{l}\mathrm{Y} \\
\mathrm{Y}\end{array}$ & $\begin{array}{l}=4,79+0,0019 x-0,0001 x^{2} \\
=4,59-0,0084 x\end{array}$ & $\begin{array}{l}0,99 \\
0,94\end{array}$ & $\begin{array}{l}* * \\
* *\end{array}$ \\
\hline Raquis & + & & & $\begin{array}{l}=0,78-0,0015 x-0,00002 x^{2} \\
=0,77-0,0034 x\end{array}$ & $\begin{array}{l}0,999 \\
0,97\end{array}$ & $*$ \\
\hline Grão & + & & & $\begin{array}{l}=1,94-0,0119 x \\
=1,70-0,0079 x\end{array}$ & $\begin{array}{l}0,98 \\
0,82\end{array}$ & $* *$ \\
\hline Total & $\overline{+}$ & & & $\begin{array}{l}=17,08-0,0374 x-0,0002 x^{2} \\
=16,41-0,051 x\end{array}$ & $\begin{array}{l}0,999 \\
0,996\end{array}$ & $\begin{array}{l}* * \\
* *\end{array}$ \\
\hline Total & & & & $=16,93-0,0565 x$ & 0,998 & $* *$ \\
\hline
\end{tabular}

(**) Significativo ao nível de $1 \%$

(*) Significatico ao nível de $5 \%$. 
Apêndice 27. Equações de regressão entre teores de nutrientes e níquel (\% e ppm) em arroz (Y), e ppm de níquel (X) em dois solos ácidos com e sem calagem (Ensaio 8).

\begin{tabular}{|c|c|c|c|c|c|c|}
\hline$V A R \quad I$ & $I \bar{A} \quad V \quad E$ & $L$ & & EQUAÇÕES DE REGRESSÃO & $R^{2}$ & F \\
\hline Parte & Nutriente & Calagem & & & & \\
\hline Folha & $\mathrm{Mg}$ & $\begin{array}{l}- \\
+ \\
- \\
+ \\
+\end{array}$ & $\begin{array}{l}\mathrm{Y} \\
\mathrm{Y} \\
\mathrm{Y} \\
\mathrm{Y} \\
\mathrm{Y} \\
\mathrm{Y}\end{array}$ & $\begin{array}{l}=0,078-0,00017 x \\
=0,088+0,00044 x \\
=1,48+0,00097 x-0,000038 x^{2} \\
=1,58-0,0009 x \\
=3329,5-21,812 x \\
=842,75-5,60 x\end{array}$ & $\begin{array}{l}0,98 \\
0,74 \\
0,99 \\
0,87 \\
0,996 \\
0,79\end{array}$ & $\begin{array}{r}\mathrm{ns} \\
* * \\
* \\
\mathrm{~ns} \\
* * \\
* *\end{array}$ \\
\hline $\begin{array}{l}\text { Colmo + } \\
\text { Perfilho }\end{array}$ & $\mathrm{Mg}$ & $\begin{array}{l}- \\
+ \\
- \\
+ \\
+\end{array}$ & $\begin{array}{l}\mathrm{Y} \\
\mathrm{Y} \\
\mathrm{Y} \\
\mathrm{Y} \\
\mathrm{Y} \\
\mathrm{Y}\end{array}$ & $\begin{array}{l}=0,98-0,0025 x \\
=1,02+0,00097 x-0,000015 x^{2} \\
=10,82-0,0537 x+0,00029 x^{2} \\
=14,76-0,117 x+0,00042 x^{2} \\
=11,59+2,333 x-0,0087 x^{2} \\
=10,15+1,831 x-0,008 x^{2}\end{array}$ & $\begin{array}{l}0,92 \\
0,91 \\
0,90 \\
0,98 \\
0,999 \\
0,996\end{array}$ & $\begin{array}{l}* * \\
\text { nis } \\
* \\
* * \\
* * \\
* *\end{array}$ \\
\hline Raiz & $\begin{array}{l}\mathrm{Ca} \\
\mathrm{Mg} \\
\mathrm{Ni}\end{array}$ & $\begin{array}{l}- \\
+ \\
- \\
+ \\
+\end{array}$ & $\begin{array}{l}\mathrm{Y} \\
\mathrm{Y} \\
\mathrm{Y} \\
\mathrm{Y} \\
\mathrm{Y} \\
\mathrm{Y}\end{array}$ & $\begin{array}{l}=0,50-0,0027 x+0,000018 x^{2} \\
=0,55+0,00055 x-0,000006 x^{2} \\
=0,47-0,00031 x+0,000005 x^{2} \\
=0,57-0,0027 x+0,000015 x^{2} \\
=32,1+3,367 x \\
=31,4+2,374 x\end{array}$ & $\begin{array}{l}0,67 \\
0,47 \\
0,46 \\
0,97 \\
0,999 \\
0,997\end{array}$ & $\begin{array}{l}* * \\
\mathrm{~ns} \\
\mathrm{~ns} \\
* \\
* * \\
* *\end{array}$ \\
\hline Folha & $\begin{array}{l}\mathrm{K} \\
\mathrm{Ca} \\
\mathrm{Mg} \\
\mathrm{Fe} \\
\mathrm{Mn} \\
\mathrm{Zn} \\
\mathrm{Ni}\end{array}$ & & $\begin{array}{l}\mathrm{Y} \\
\mathrm{Y} \\
\mathrm{Y} \\
\mathrm{Y} \\
\mathrm{Y} \\
\mathrm{Y} \\
\mathrm{Y}\end{array}$ & $\begin{array}{l}=2,75+0,0048 x \\
=1,52+0,0009 x-0,000025 x^{2} \\
=1,56-0,00235 x \\
=310,8+1,838 x-0,016 x^{2} \\
=2086-13,706 x \\
=42,8-0,118 x \\
=11,72+1,736 x-0,0042 x^{2}\end{array}$ & $\begin{array}{l}0,97 \\
1,00 \\
0,89 \\
0,99 \\
0,99 \\
0,94 \\
0,997\end{array}$ & $\begin{array}{l}* * \\
* \\
* * \\
* * \\
* * \\
* * \\
* *\end{array}$ \\
\hline $\begin{array}{l}\text { Colmo + } \\
\text { Perfilho }\end{array}$ & $\begin{array}{l}\mathrm{Ca} \\
\mathrm{Mg} \\
\mathrm{Cu} \\
\mathrm{Mn} \\
\mathrm{Zn} \\
\mathrm{Ni}\end{array}$ & & $\begin{array}{l}\mathrm{Y} \\
\mathrm{Y} \\
\mathrm{Y} \\
\mathrm{Y} \\
\mathrm{Y} \\
\mathrm{Y}\end{array}$ & $\begin{array}{l}=0,53+0,00024 \dot{x}-0,000009 x^{2} \\
=1,015-0,0017 x \\
=12,79-0,085 x+0,00036 x^{2} \\
=501,6-2,507 x \\
=156,4-2,338 x+0,012 x^{2} \\
=10,87+2,082 x-0,0084 x^{2}\end{array}$ & $\begin{array}{l}0,86 \\
0,999 \\
0,96 \\
0,93 \\
1,00 \\
0,998\end{array}$ & $\begin{array}{l}* \\
* * \\
* * \\
* * \\
* * \\
* *\end{array}$ \\
\hline Raiz & $\begin{array}{l}\mathrm{N} \\
\mathrm{K} \\
\mathrm{Cu} \\
\mathrm{Mn} \\
\mathrm{Zn} \\
\mathrm{Ni}\end{array}$ & & $\begin{array}{l}\mathrm{Y} \\
\mathrm{Y} \\
\mathrm{Y} \\
\mathrm{Y} \\
\mathrm{Y}\end{array}$ & $\begin{array}{l}=0,89+0,0035 x-0,00002 x^{2} \\
=0,437+0,0015 x \\
=34,05-0,058 x \\
=128-0,351 x \\
=56,125-0,115 x \\
=31,75+2,871 x\end{array}$ & $\begin{array}{l}0,57 \\
0,86 \\
0,77 \\
0,94 \\
0,60 \\
0,998\end{array}$ & $\begin{array}{l}\mathrm{ns} \\
* * \\
* * \\
* * \\
* \\
* *\end{array}$ \\
\hline
\end{tabular}

(**) Significativo ao nível de $1 \%$

(*) Significativo ao nível de $5 \%$

(ns) Não significativo 
Apêndice 28. Teores foliares de nutrientes (\% e ppm) em arroz variedade IAC-165, em função dos níveis de $\mathrm{Ni}$ e da calagem em dois so los ácidos (Ensaio 8) ${ }^{1}$.

\begin{tabular}{|c|c|c|c|c|c|c|c|c|c|c|c|c|}
\hline Solos & Calagem & $\mathrm{Ni}$ & $\mathrm{N}$ & $P$ & $\mathrm{~K}$ & $\mathrm{Ca}$ & Mg & $s^{2}$ & $\mathrm{Cu}$ & $\mathrm{Fe}$ & $\mathrm{Mn}$ & $\mathrm{Zn}$ \\
\hline & & $\mathrm{ppm}$ & $-\cdots$ & $--\infty$ & ---- & $\%---$ & & ---- & $-\cdots$ & - ppm & $1--$ & --- \\
\hline \multirow[t]{8}{*}{ LRd } & - & 0 & 1,19 & 0,07 & 3,30 & 0,93 & 1,40 & 0,22 & 10 & 3041 & 1900 & 36 \\
\hline & & 30 & 0,96 & 0,08 & 3,20 & 1,09 & 1,44 & 0,30 & 9 & 3381 & 1705 & 38 \\
\hline & & 60 & 1,22 & 0,08 & 3,65 & 1,24 & 1,33 & 0,34 & 9 & 3671 & 1105 & 28 \\
\hline & & 120 & 0,80 & 0,07 & 3,60 & 1,12 & 1,14 & 0,33 & 6 & 348 & 920 & 24 \\
\hline & + & 0 & 1,37 & 0,12 & 3,70 & 1,48 & 1,40 & 0,36 & 11 & 339 & 406 & 40 \\
\hline & & 30 & 1,22 & 0,10 & 3,20 & 1,52 & 1,42 & 0,36 & 10 & 384 & 488 & 38 \\
\hline & & 60 & 1,16 & 0,11 & 3,60 & 1,26 & 1,41 & 0,35 & 11 & 328 & 292 & 36 \\
\hline & & 120 & 1,61 & 0,14 & 3,60 & 1,26 & 1,47 & 0,36 & 9 & 261 & 249 & 32 \\
\hline \multirow[t]{8}{*}{$\mathrm{TE}$} & - & 0 & 0,98 & 0,08 & 1,90 & 1,67 & 1,54 & 0,30 & 10 & 2894 & 4880 & 48 \\
\hline & & 30 & 1,07 & 0,07 & 2,60 & 1,56 & 1,56 & 0,44 & 11 & 3573 & 3435 & 42 \\
\hline & & 60 & 0,94 & 0,06 & 2,55 & 1,55 & 1,42 & 0,43 & 12 & 3933 & 3010 & 42 \\
\hline & & 120 & 1,05 & 0,05 & 3,10 & 1,00 & 0,96 & 0,33 & 14 & 300 & 520 & 28 \\
\hline & + & 0 & 0,82 & 0,12 & 2,20 & 1,99 & 1,74 & 0,38 & 12 & 3031 & 1260 & 40 \\
\hline & & 30 & 1,10 & 0,09 & 2,35 & 1,90 & 1,74 & 0,35 & 14 & 3441 & 1155 & 47 \\
\hline & & 60 & 1,19 & 0,11 & 2,50 & 1,88 & 1,61 & 0,36 & 12 & 353 & 320 & 38 \\
\hline & & 120 & 0,72 & 0,15 & 3,00 & 1,68 & 1,47 & 0,39 & 12 & 297 & 220 & 28 \\
\hline \multicolumn{2}{|c|}{ C.V. \% } & & 12,0 & 27,9 & 9,4 & 7,0 & 7,1 & - & 16,8 & 13,3 & 19,7 & 9,3 \\
\hline
\end{tabular}

(1) Média de 2 repetições

(2) Sem repetição 
Apêndice 29. Teores de níquel em arroz variedade IAC-165, em função dos níveis de níquel e da calagem em dois solos ácidos (Ensaio $8)^{1}$.

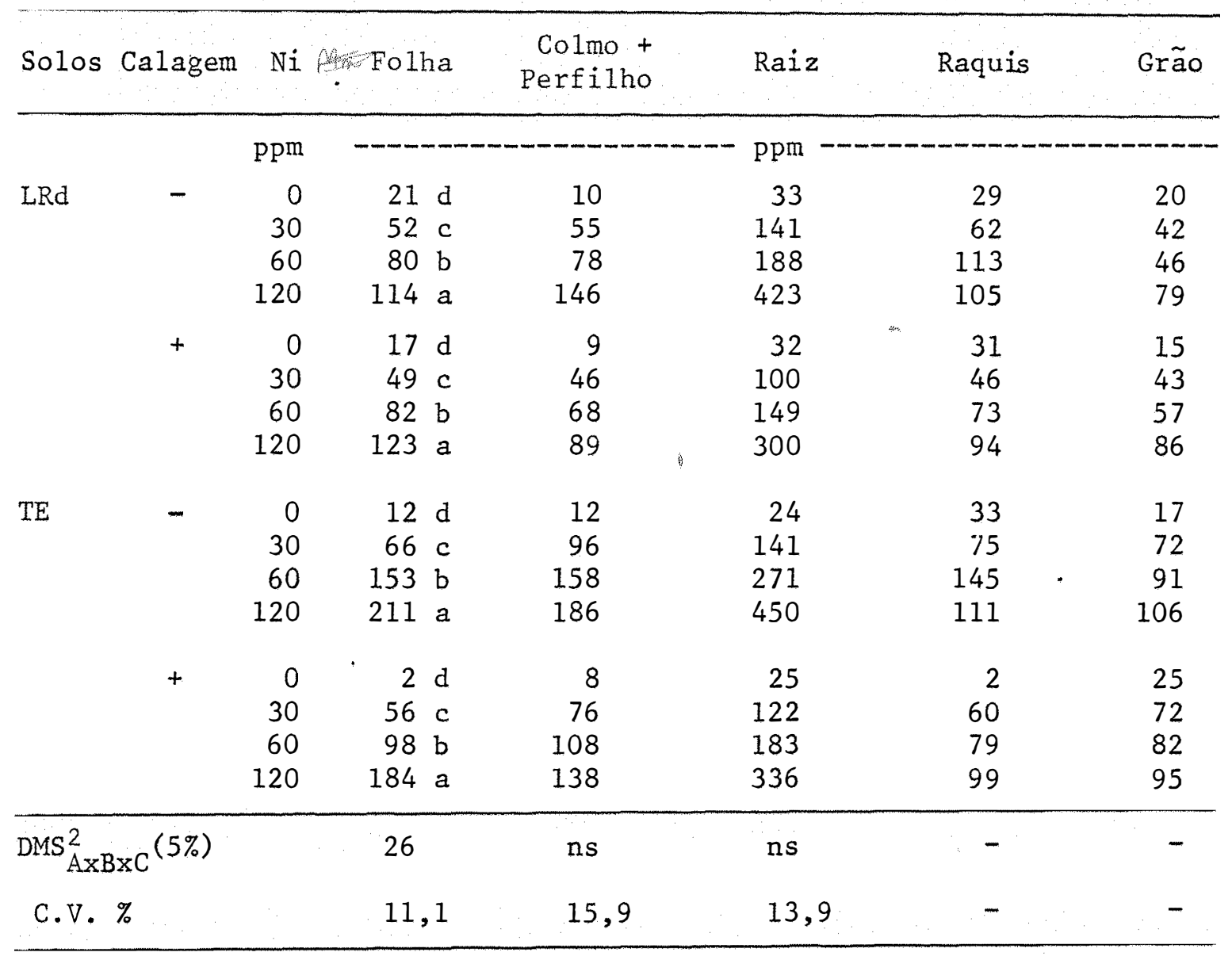

(1) Mëdia de 2 repetições

(2) Comparação de médias pelo teste de Tukey, da interação solos x calagem $x$ níveis de $\mathrm{Ni}$

(ns) Não significativo 
Apêndice 30. Teores de Ni extraível em DTPA-TEA $(\mu \mathrm{g} / \mathrm{ml})$ em três solos ãcidos.

\begin{tabular}{|c|c|c|c|c|c|}
\hline \multirow[t]{2}{*}{ Solos } & \multirow{2}{*}{$\begin{array}{r}\mathrm{Ni} \\
\mathrm{ppm}\end{array}$} & \multirow{2}{*}{ Calagem } & \multicolumn{2}{|c|}{ Tempos de incubação } & \multirow{2}{*}{$\frac{(\text { dias) }}{222}$} \\
\hline & & & 28 & 138 & \\
\hline \multirow[t]{4}{*}{ V } & 0 & - & 0,83 & 0,84 & 0,94 \\
\hline & 30 & & 12,10 & 7,90 & 9,30 \\
\hline & 60 & & 21,40 & 17,20 & 17,20 \\
\hline & 120 & & 37,10 & 34,10 & 34,40 \\
\hline \multirow[t]{8}{*}{ LRd } & 0 & - & 0,02 & 0,03 & 0,02 \\
\hline & 30 & & 5,71 & 3,85 & 4,31 \\
\hline & 60 & & 14,70 & 10,30 & 9,30 \\
\hline & 120 & & 27,10 & 20,00 & 20,70 \\
\hline & 0 & + & 0,02 & 0,02 & 0,03 \\
\hline & 30 & & 5,10 & 3,67 & 3,28 \\
\hline & 60 & . & 9,70 & 9,60 & 8,26 \\
\hline & 120 & & 22,10 & 17,20 & 21,10 \\
\hline \multirow[t]{8}{*}{ TE } & 0 & - & 0,02 & 0,02 & 0,02 \\
\hline & 30 & & 4,68 & 3,38 & 3,58 \\
\hline & 60 & & 12,40 & 11,20 & 10,70 \\
\hline & 120 & & 24,20 & 24,40 & 19,50 \\
\hline & 0 & + & 0,02 & 0,02 & 0,02 \\
\hline & 30 & & 3,83 & 3,86 & 2,92 \\
\hline & 60 & & 8,74 & 8,70 & 7,16 \\
\hline & 120 & & 20,80 & 17,80 & 18,30 \\
\hline
\end{tabular}

